\title{
An Archaeological Assessment of San Pedro Park, (41BX19) San Antonio, Texas
}

Barbara A. Meissner

Center for Archaeological Research

Follow this and additional works at: https://scholarworks.sfasu.edu/ita

Part of the American Material Culture Commons, Archaeological Anthropology Commons, Environmental Studies Commons, Other American Studies Commons, Other Arts and Humanities Commons, Other History of Art, Architecture, and Archaeology Commons, and the United States History Commons

Tell us how this article helped you.

This Article is brought to you for free and open access by the Center for Regional Heritage Research at SFA ScholarWorks. It has been accepted for inclusion in Index of Texas Archaeology: Open Access Gray Literature from the Lone Star State by an authorized editor of SFA ScholarWorks. For more information, please contact cdsscholarworks@sfasu.edu. 


\section{An Archaeological Assessment of San Pedro Park, (41BX19) San Antonio, Texas \\ Creative Commons License \\ (c) () () (9)}

This work is licensed under a Creative Commons Attribution-NonCommercial 4.0 International License 


\section{An Archaeological Assessment of}

San Dellot 1.11. (19)

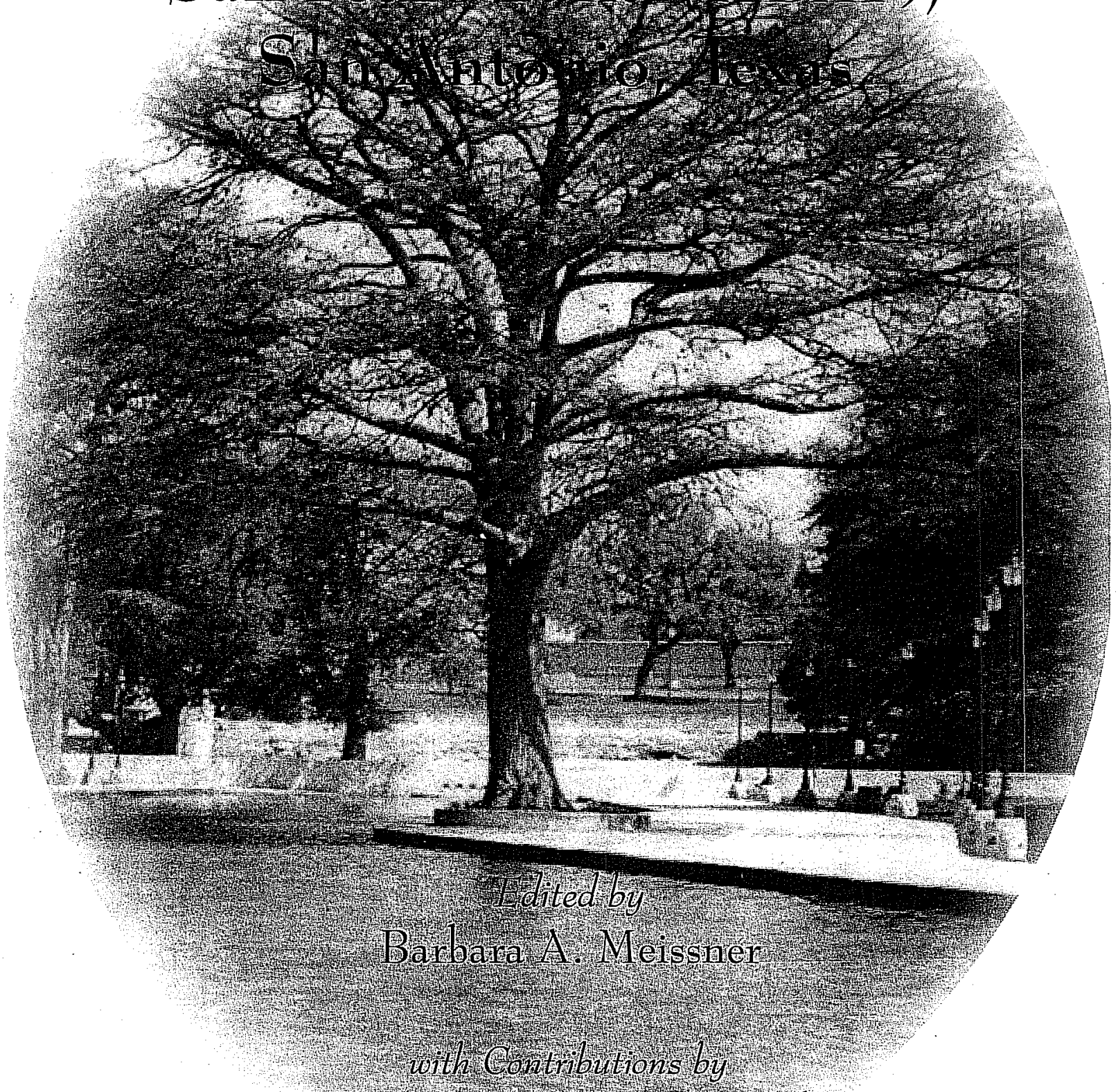

I. Waynne Cox, Brett A. Houk,

David L. Nickels and Bradley J. Vierra

Center for Archaeological Research The University of Texas at San Antonio Archaeological Survey Report, No. 269 2000 



\title{
An Archaeological Assessment of San Pedro Park, (41BX19) San Antonio, Texas
}

\author{
Edited by \\ Barbara A. Meissner
}

with Contributions by

I. Waynne Cox, Brett A. Houk, David L. Nickels and Bradley J. Vierra

Robert J. Hard and C. Britt Bousman Principal Investigators

Texas Antiquities Permit No. 1929

Ccopyright 2000

Center for Archaeological Research

The University of Texas at San Antonio Archaeological Survey Report, No. 269 
The following information is provided in accordance with the General Rules of Practice and Procedure, Chapter 41.11 (Investigative Reports), Texas Antiquities Committee:

1. Type of investigation: Historic and Archaeological Assessment and Investigation

2. Project name: San Pedro Park Southwest Corner (SARA Ashby Area Project)

3. County: Bexar

4. Principal investigators: Robert J. Hard and C. Britt Bousman

5. Name and location of sponsoring agency: San Antonio River Authority, 100 East Guenther Street, San Antonio, Texas 78283-0027

6. Texas Antiquities Permit No.: 1929

7. Published by the Center for Archaeological Research, The University of Texas at San Antonio, 6900 N. Loop 1604 W., San Antonio, Texas 78249-0658, 2000

A list of publications offered by the Center for Archaeological Research is available. Call (210) 458-4378; write to the Center for Archaeological Research, The University of Texas at San Antonio, 6900 N. Loop 1604 W., San Antonio, Texas 78249-0658; e-mail to car@lonestar.utsa.edu; or visit CAR's web site at http://car.utsa.edu/. 


\begin{abstract}
In July 1996, the Center for Archaeological Research (CAR) of The University of Texas at San Antonio (UTSA) conducted shovel testing and backhoe trenching operations along the western edge of San Pedro Park, near downtown San Antonio, Texas. The purpose of the testing was to determine the exact location at which the Alazán acequia would be impacted by a planned drainage improvement project under North Flores Street, and to then assess the likelihood that the project would significantly impact buried cultural material. Using old maps as guides, the acequia was located approximately $55 \mathrm{~m}$ south of Ashby Street. It was unlined, and cut $90 \mathrm{~cm}$ into bedrock, with its bottom $295 \mathrm{~cm}$ below the modern ground surface. Although no cultural materials were found in the acequia, a series of shovel tests produced 1085 artifacts, both Prehistoric and Historic. Due to the depth of previously disturbed sediments under North Flores Street, CAR determined it was unlikely that significant archaeological deposits would be encountered, and recommended that the project be allowed to proceed as planned. However, the results of the shovel testing indicated that there were previously undisturbed areas along the western edge of the park that were likely to contain intact buried cultural deposits. Based on these results, CAR recommended that any planned construction within the park be preceded by an archaeological testing program to further assess the nature and potential significance of those deposits.
\end{abstract}

Following the 1996 testing project, one of the subcontractors for the drainage improvement project used the southwest corner of San Pedro Park as a staging area for construction. CAR returned to this southwest corner of in April 1998 to conduct further shovel testing, along with 1-x-1 m unit excavations, to determine the extent to which any buried archaeological deposits had been impacted by the heavy machinery and stockpiles of gravel, sand, and other construction materials stored in the park. An analysis of the artifact assemblage, along with finite comparisons of the topography before and after the construction staging area was used, indicate that the area was impacted by the construction company.

A detailed set of recommendations for management of the cultural resources of San Pedro Park is included in the final chapter of this document. 


\section{Contents}

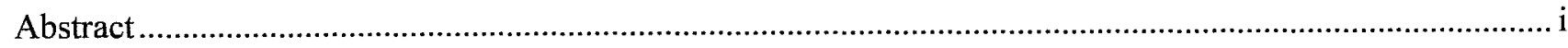

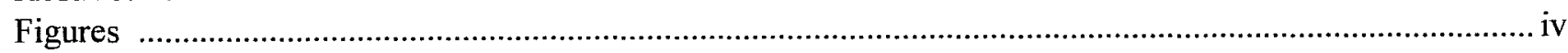

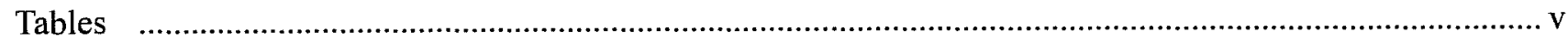

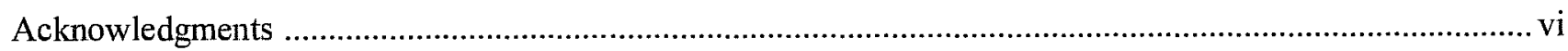

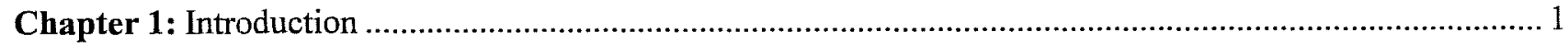

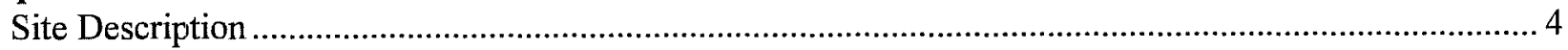

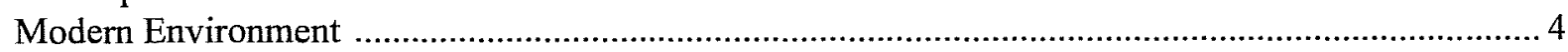

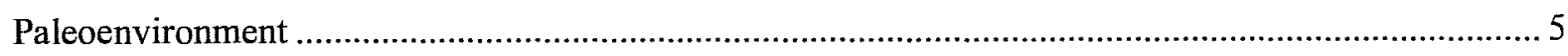

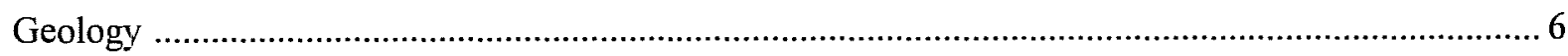

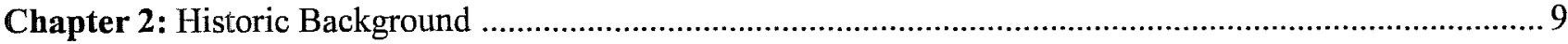

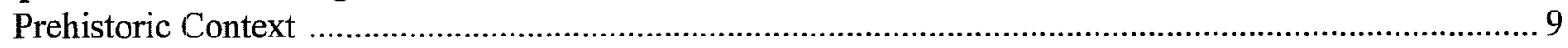

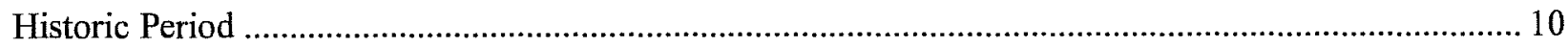

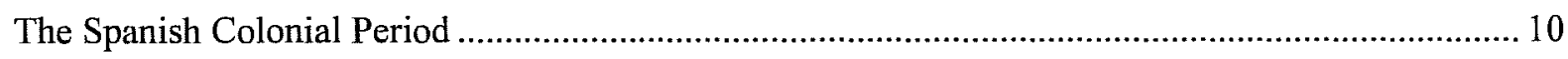

San Pedro Park in the Nineteenth Century .......................................................................... 12

San Pedro Park in the Twentieth Century .............................................................................. 15

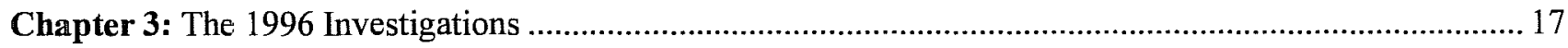

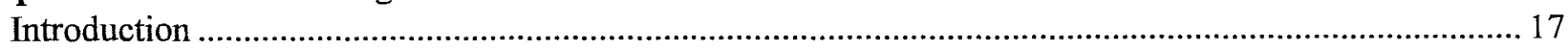

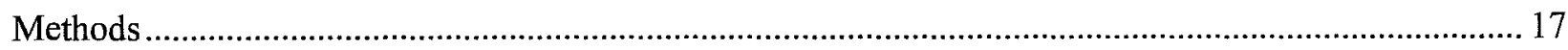

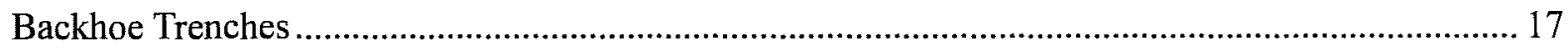

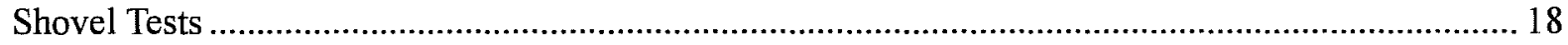

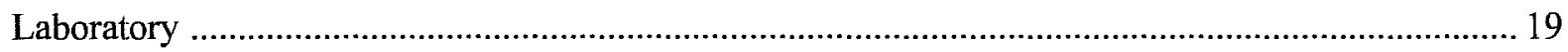

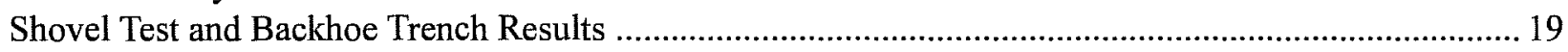

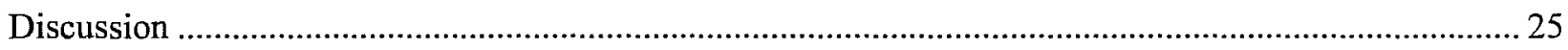

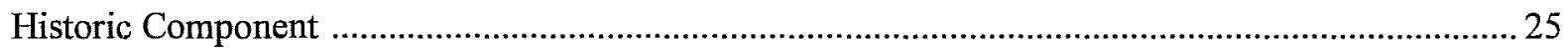

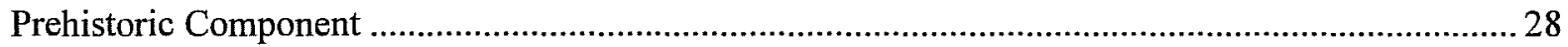

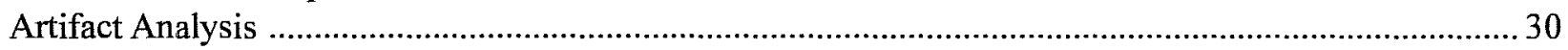

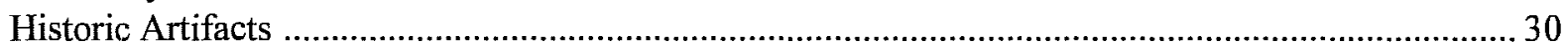

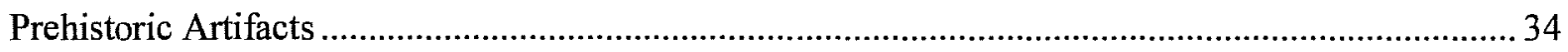

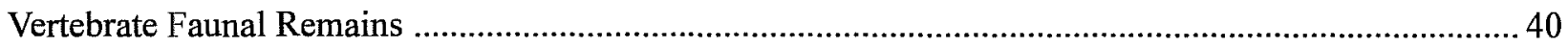

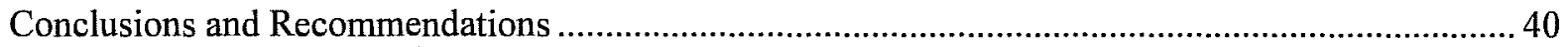

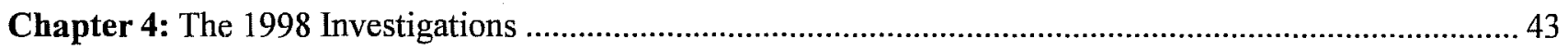

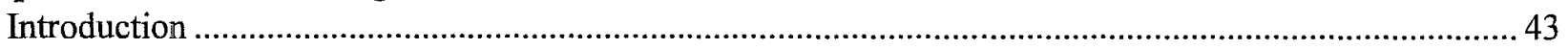

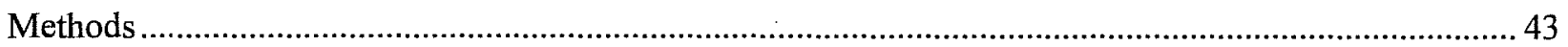

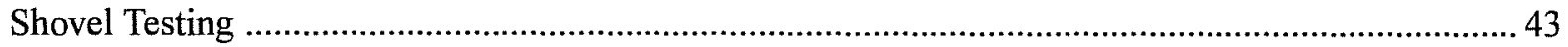

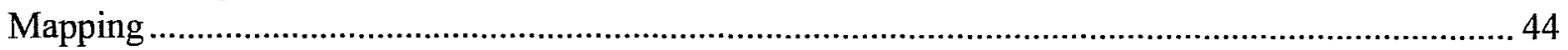

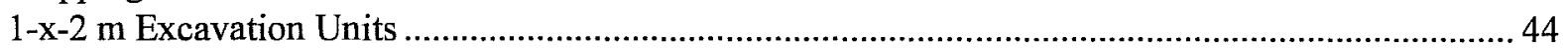

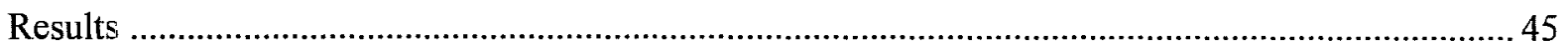

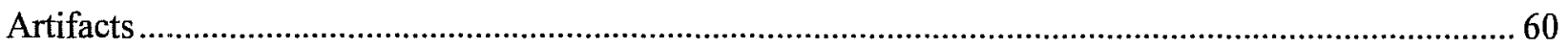

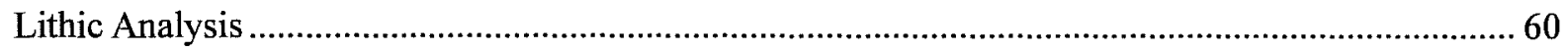

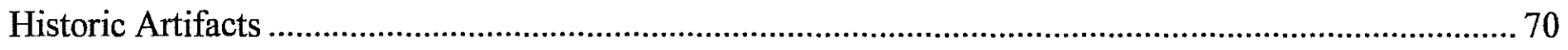

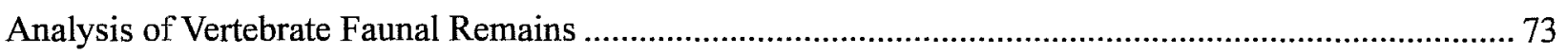

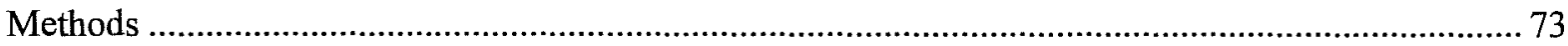

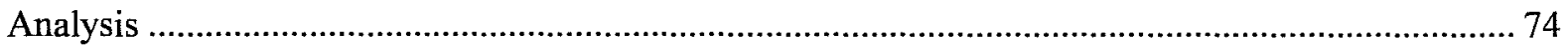

Nature of Impacts to Cultural Deposits in Project Area ................................................................. 76

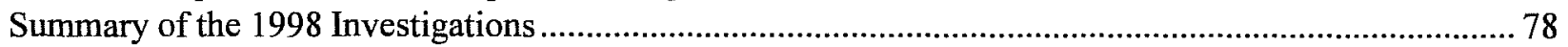


Chapter 5: Recommendations for Management of Cultural Resources at San Pedro Park ......................... 79

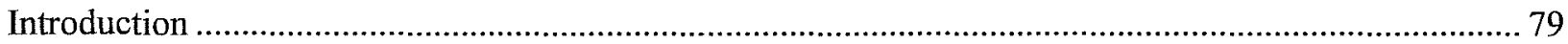

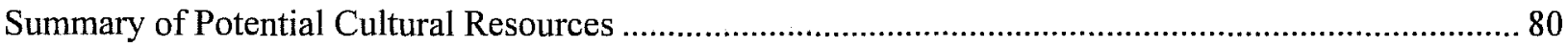

Summary of Known Impacts on Cultural Resources .................................................................. 8 81

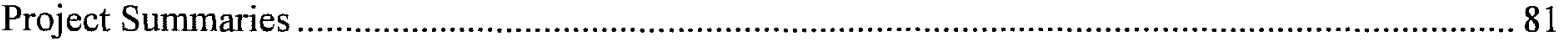

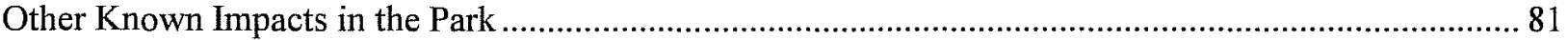

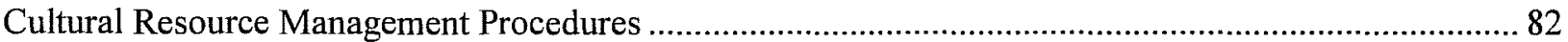

Recommended Cultural Resource Management Procedures ............................................................. 83

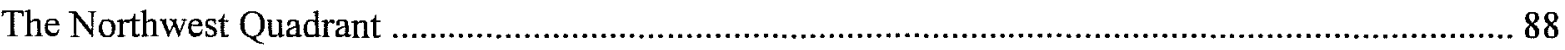

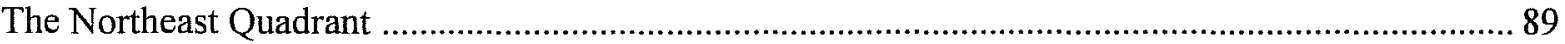

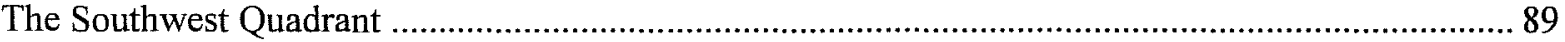

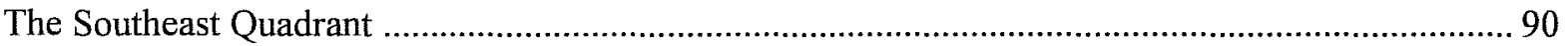

Recommendations for Increasing Public Awareness ..................................................................... 91

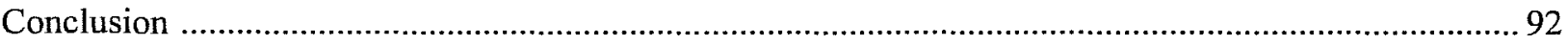

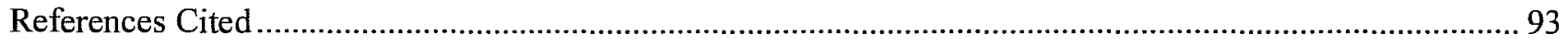

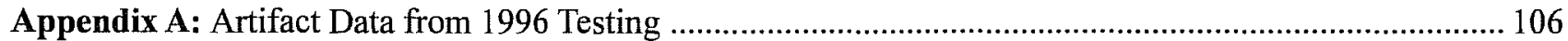

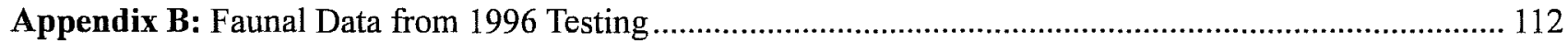

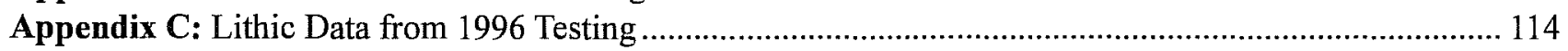

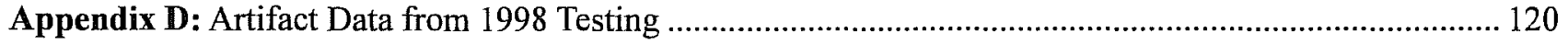

Appendix E: Faunal Data from 1998 Testing ................................................................................ 124 


\section{Figures}

Figure 1. Project location: San Pedro Park and vicinity. .......................................................................

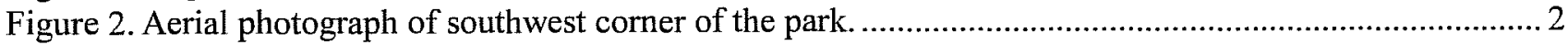

Figure 3. Red sandy loam on a portion of the ground surface of the park. ................................................. 3

Figure 4. Drawing of San Pedro Springs by Herman Lungkwitz, ca. 1850 . ............................................ 4

Figure 5. The main spring of San Pedro Springs, in July 1996........................................................ 5

Figure 6. Park map showing bedrock formation, faults and location of geotechnical bore holes. .................6 6

Figure 7. Profile of boreholes along western edge of the park. ............................................................. 7

Figure 8. Map showing modern streets and location of three acequias in the vicinity of the park...................8

Figure 9. Map of San Pedro Park drawn in the 1870s. ....................................................................... 14

Figure 10. San Pedro Park in the early 1900s. .............................................................................. 16

Figure 11. Map of the west side of San Pedro Park, showing location of shovel tests and backhoe trenches.. 17

Figure 12. Northwest corner of park in 1899, showing the estimated course of the Alazán acequia. ............. 18

Figure 13. CAR personnel working on shovel tests 1, 2, and 3, in the northwest corner of the park............. 19

Figure 14. Profile of BHT A, showing the remains of the Alazán acequia. ................................................ 24

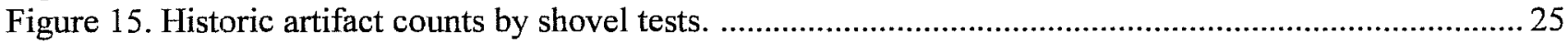

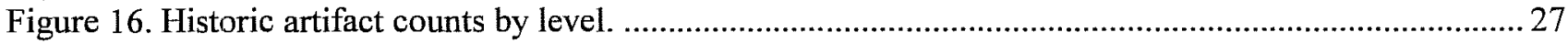

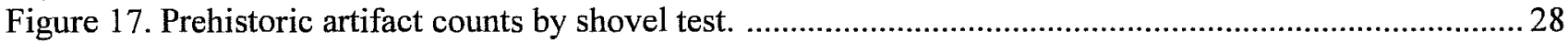

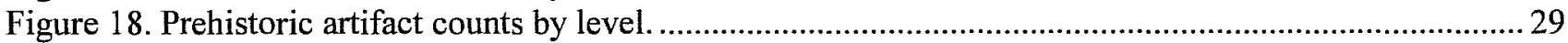

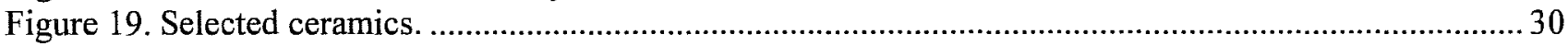

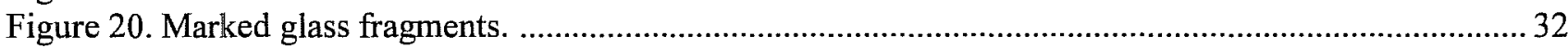

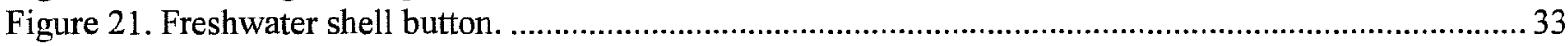

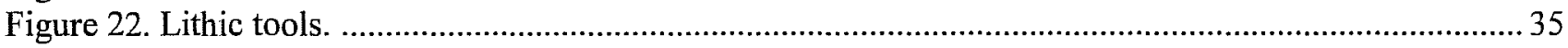

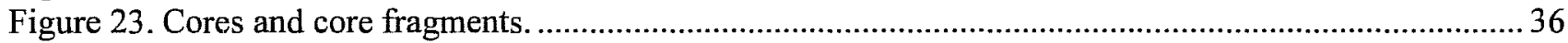

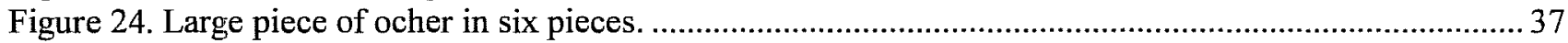

Figure 25. Lithics from area near the main springs. ................................................................ 38

Figure 26. Southwestern corner of park, showing location of 1998 project. ............................................ 43

Figure 27. Map of 1998 project area, and 1996 shovel tests and backhoe trench...................................... 44

Figure 28. Schematic representation of the vertical distribution of soils and sediments in shovel tests. ......... 45

Figure 29. Plan map of project area with the approximate distribution of surface soils and sediments. .........46

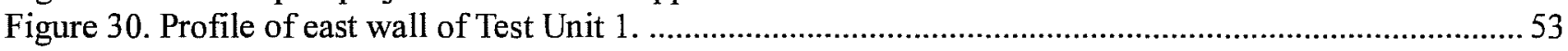

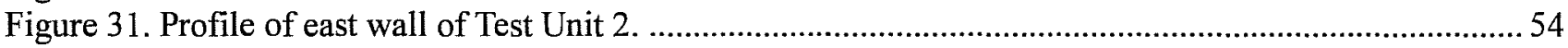

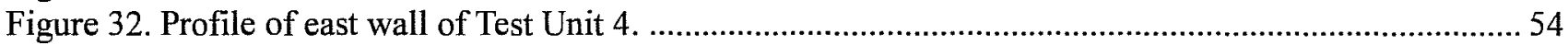

Figure 33. Photograph of Test Unit 4, showing recent fill and sprinkler system components. ...................... 55

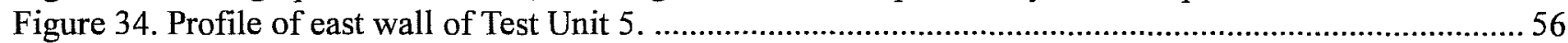

Figure 35. Contour map comparing 1996 pre-impact topography to 1998 post-impact topography. ..............57

Figure 36. Contour map comparing 1996 pre-impact surface with uncompacted clay loam..........................58

Figure 37. Contour map of differences in clay loam surface. ............................................................5 59

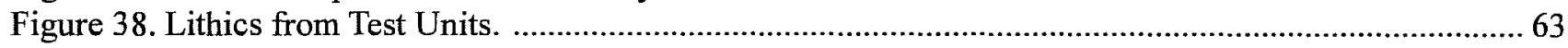

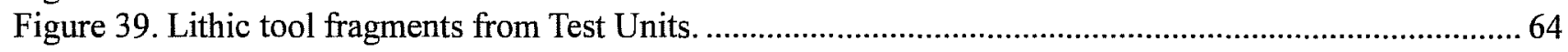

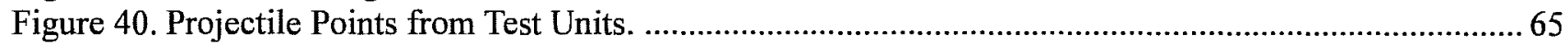

Figure 41. Selected Historic Artifacts. ........................................................................................... 71

Figure 42. Graph showing Historic and Prehistoric artifact counts by level in Test Units. ...........................78

Figure 43. Photograph of the new pond in San Pedro Park ................................................................ 79

Figure 44. The southwest corner of the park today. ........................................................................... 80

Figure 45. Map of northwest quadrant of San Pedro Park. ............................................................. 84

Figure 46. Map of northeast quadrant of San Pedro Park. ................................................................. 85

Figure 47. Map of southwest quadrant of San Pedro Park. .................................................................. 86

Figure 48. Map of southeast quadrant of San Pedro Park. ................................................................. 87

Figure 49. San Pedro Park today, looking south from above the main spring. ........................................ 92 


\section{Tables}

Table 1. Prehistoric Cultural Intervals (based on Hunziker et al. 1997) ................................................... 9

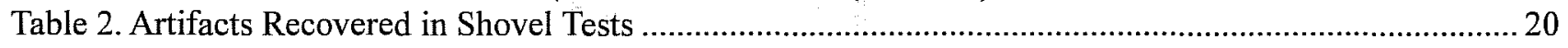

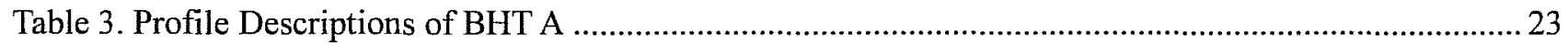

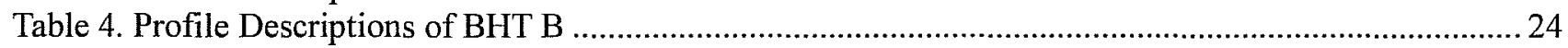

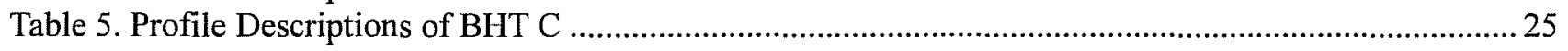

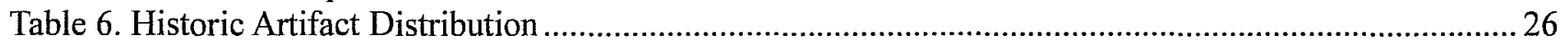

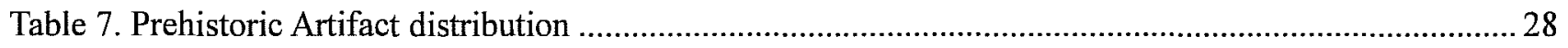

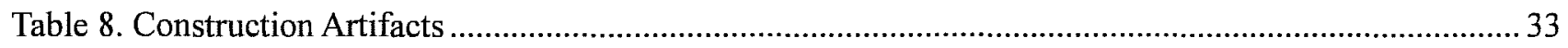

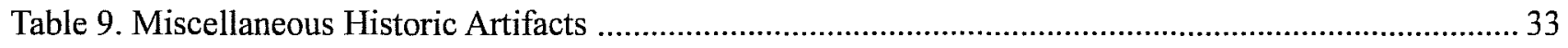

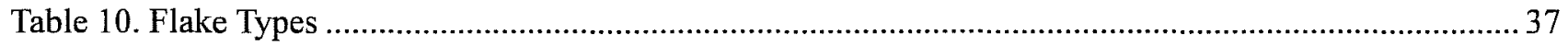

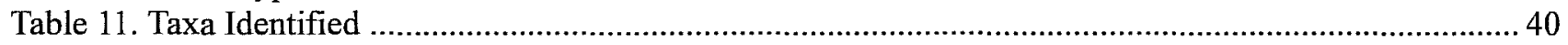

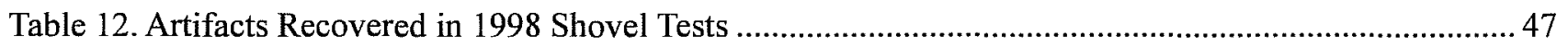

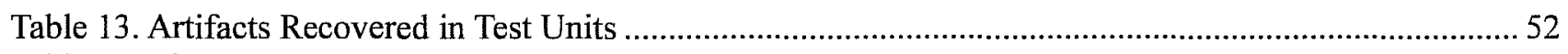

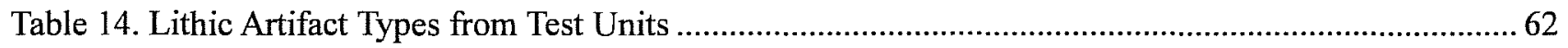

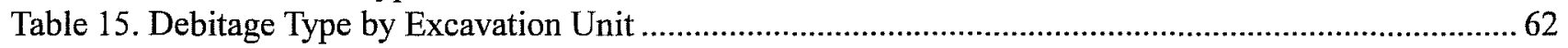

Table 16. Contingency Table of Debitage Type by Flake Condition …..................................................6

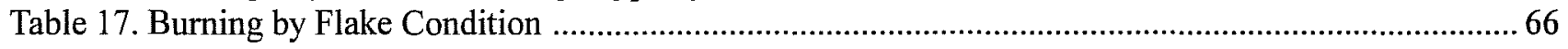

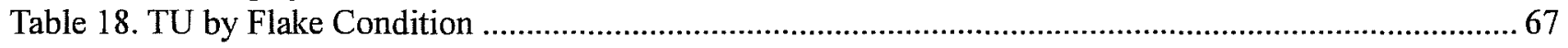

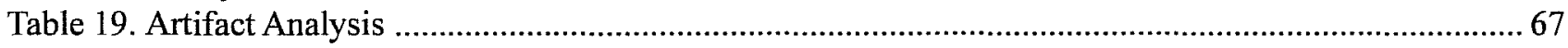

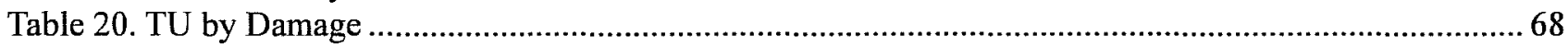

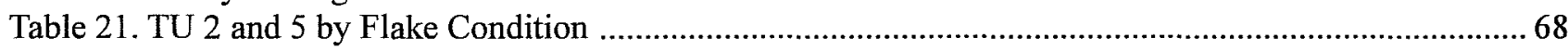

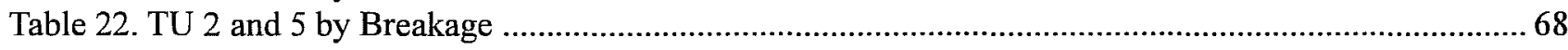

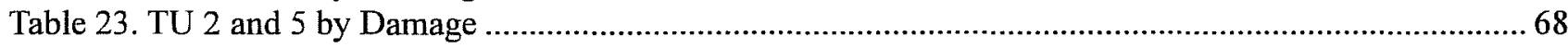

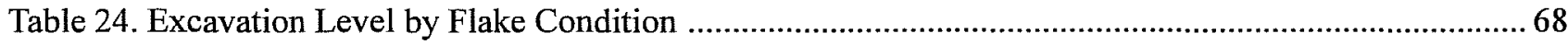

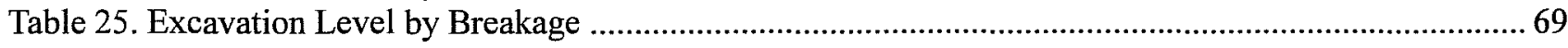

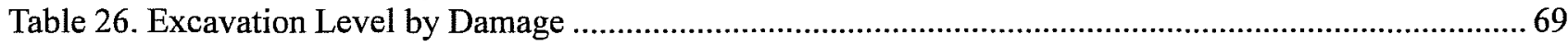

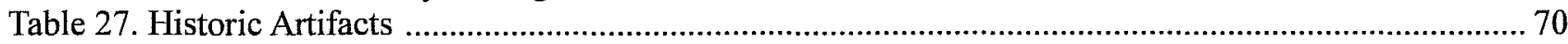

Table 28. Identified Vertebrate Taxa from 1998 Project ..................................................................... 73

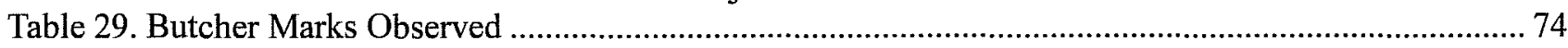

Table 30. Count and Percentage of Bone Exhibiting Fresh Breaks ......................................................... 75

Table 31. Number of Bones with Fresh and Old Breaks by Test Units ................................................ 75

Table 32. Cultural Resource Management Recommendations ............................................................. 83 


\section{Acknowledgments}

In the first phase of field work, Terry Conn of the San Antonio River Authority was extremely helpful, providing us with, among other things, a surveyed map of the study area. In the second phase of field work, Dean Bayer assisted the project in many ways, and his comments were very much appreciated. Scott Stover, superintendent of parks design, Parks and Recreation Department, City of San Antonio, allowed access to the park and was very helpful and cooperative in other ways. In particular, he allowed us to borrow two old maps of San Pedro Park, which facilitated production of this report.

John Wright and Mike Fulghum of Wrightway Backhoe provided their usual fine service, and Benny Ortiz did an excellent job as backhoe operator for the project. Project archaeologists for the two projects were Barbara A. Meissner and Brett A. Houk. Crewmembers were: I. Waynne Cox, David Cruz, Donna Edmondson, Jeff Francis, Owen Ford, Kevin Hanselka, Chris Horrell, Edgar Johnson, Kimberly Kvernes, Tony Lyle, Preston McWhorter, Bruce Moses, Ruth Mathews, and Andrew Scease. Lisa Durack, a volunteer from the Southern Texas Archaeological Association, also assisted in the field. Anne Fox helped with the lab work, and Andrew Scease helped with the artifact analysis. Thanks to Steve Tomka and Wilson McKinney for their assistance with the lithic artifacts from the 1996 project.

CAR director, Robert J. Hard, and acting director, C. Britt Bousman were very supportive. Comments on drafts of this manuscript by Dr. Hard, Dr. Bousman, and Cindy Tennis were invaluable and are appreciated. We could not operate without the abilities of CAR office manager, Sherri Suñaz, and to Maryanne King, Marcie Renner, and Bill Bishel, our able technical editors-who each have had an opportunity to work on this report, our gratitude is extended. To all, the authors would like to say "Thanks again!" 


\section{Chapter 1: Introduction}

\section{Barbara A. Meissner}

San Pedro Springs in San Pedro Park is one of the major springs in the San Antonio area, and has served as a gathering place for humans for several millennia. In the historic period, the presence of San Pedro Springs is one of the major reasons for the placement of the Spanish mission, presidio, and town that formed the nucleus of the modern city of San Antonio. Despite the historic and prehistoric importance of the springs and park, prior to the investigations described in this report, only one limited archaeological project had been conducted within the park (Fox 1978).

In July 1996, the Center for Archaeological Research (CAR) of The University of Texas at San Antonio (UTSA) contracted with the San Antonio River
Authority (SARA) to conduct archaeological investigations in San Pedro Park, located just north of downtown San Antonio, Texas (Figure 1). The purpose of the testing was to determine the exact location at which the remains of the Alazán acequia would be impacted by a planned drainage improvement project under North Flores Street, and to then assess the likelihood that the project would significantly impact buried cultural material. A State of Texas Antiquities Permit (\#1929) was issued for the project. Using old maps as guides, the acequia was located. By using a series of shovel tests along the western part of the park CAR determined that previous construction on North Flores Street had probably already impacted any cultural deposits immediately under the street, and

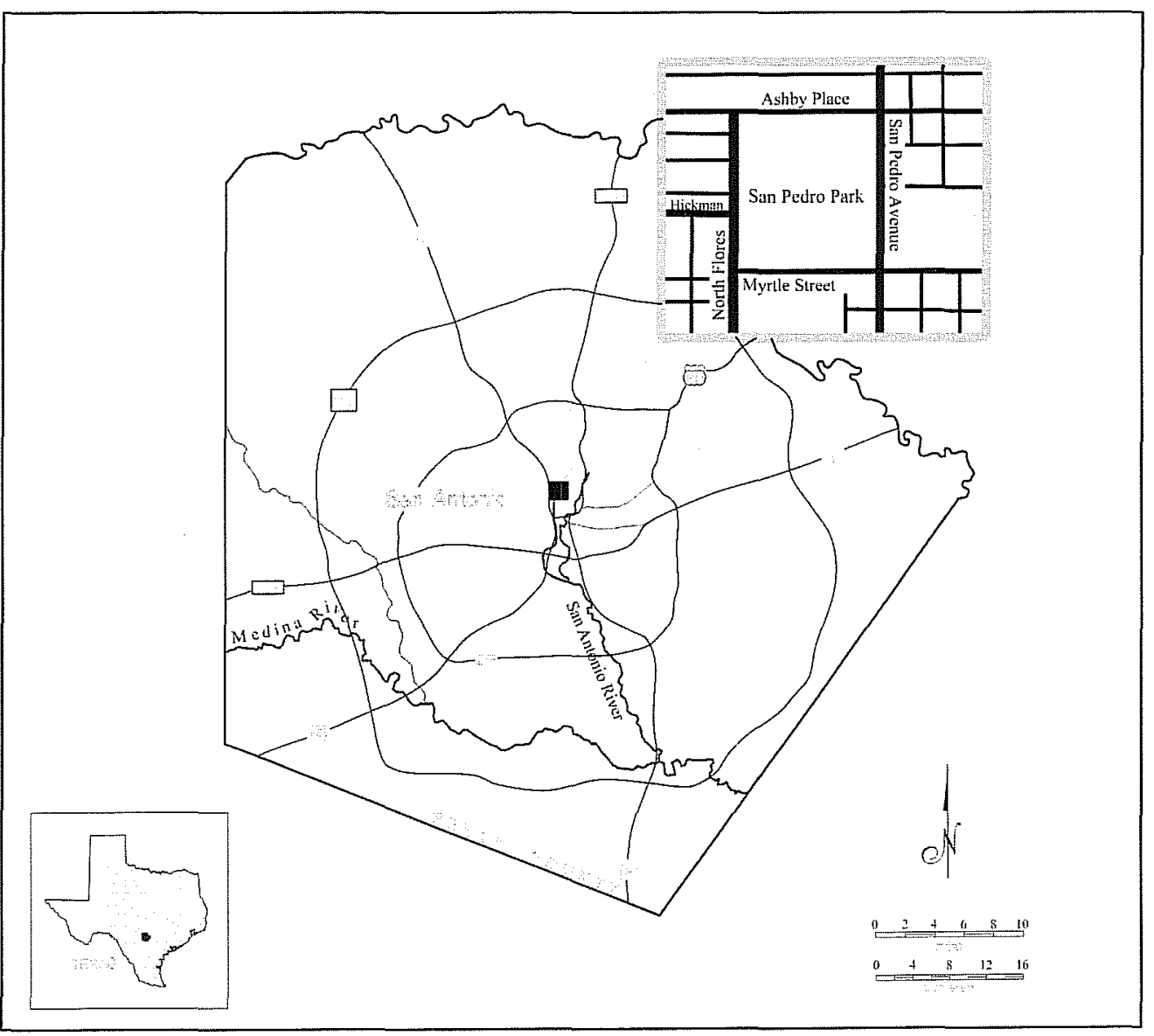

Figure 1. Project location: San Pedro Park and vicinity. 


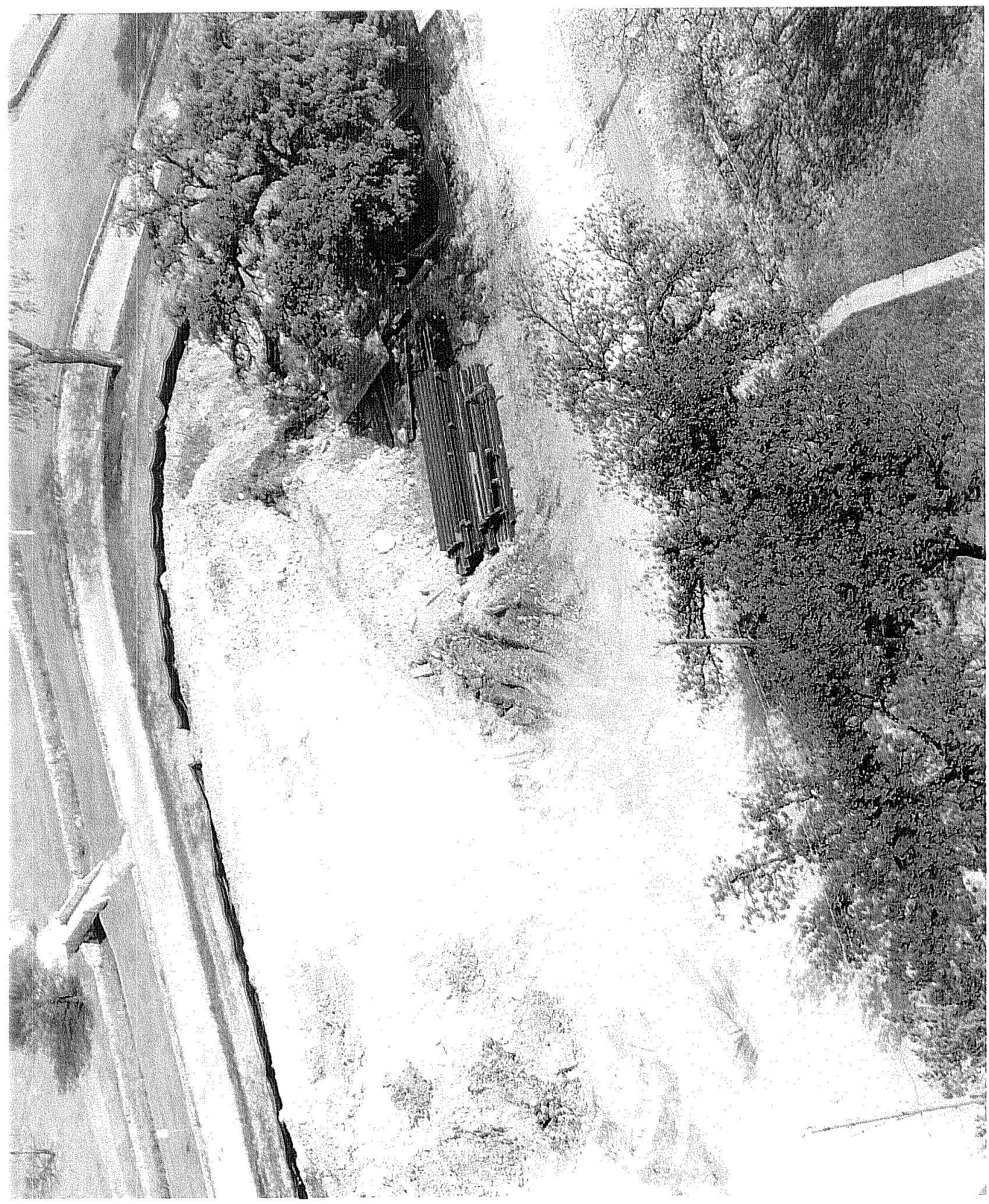

Figure 2. Aerial photograph of southwest corner of the park, showing damage to ground surface from heavy equipment and construction stockpiles. 
recommended that the project be allowed to proceed as planned. However, the results of the shovel tests indicated that there were previously undisturbed areas along the western edge of the park that were likely to contain intact buried cultural deposits. Based on the results, CAR recommended that an archaeological testing program to further assess the nature and potential significance of those deposits precede any planned construction within the park.

Subsequent to the 1996 testing project, Ramex, Incorporated, SARA's subcontractor for the drainage improvement project under construction on North Flores and adjacent streets, unaware of its cultural importance, used the southwest corner of the park as a staging area for construction (Figure 2). After negotiations between SARA, the Texas Historical Commission (THC), the City of San Antonio Historic Preservation Office, and CAR, it was decided that a testing project was required to assess the impact of these unauthorized activities to the prehistoric component in the southwest corner of the park. Furthermore, it was agreed that these investigations would be conducted under the existing antiquities permit (\#1929), and included as a separate section to the 1996 testing report.
Accordingly, CAR returned to the southwest corner of the park in April 1998 to conduct further shovel testing, along with $1-\mathrm{x}-2 \mathrm{~m}$ unit excavations, to determine the extent to which any buried archaeological deposits had been impacted by the heavy machinery and stockpiles of gravel, sand, and other construction materials stored in the park.

It was evident from an examination of the surface prior to testing that reddish sandy loam, sand, and gravel had been artificially deposited across a large portion of the southwest corner (Figure 3). The surface inspection alone, however, could not determine whether the original ground surface had been altered prior to the deposition of the new soil, sediments, and gravels. It was proposed that a systematic program of shovel testing, combined with test unit excavations, could determine the depth of the intrusive matrix and the degree of disturbance to the natural surface. This latter goal would be achieved by two processes: (1) an assessment of the structure of the underlying soils and sediments to determine whether they had been compacted by the heavy machinery and construction materials; and (2) a comparison of contours of the surface before and after impact by the machinery and construction materials.

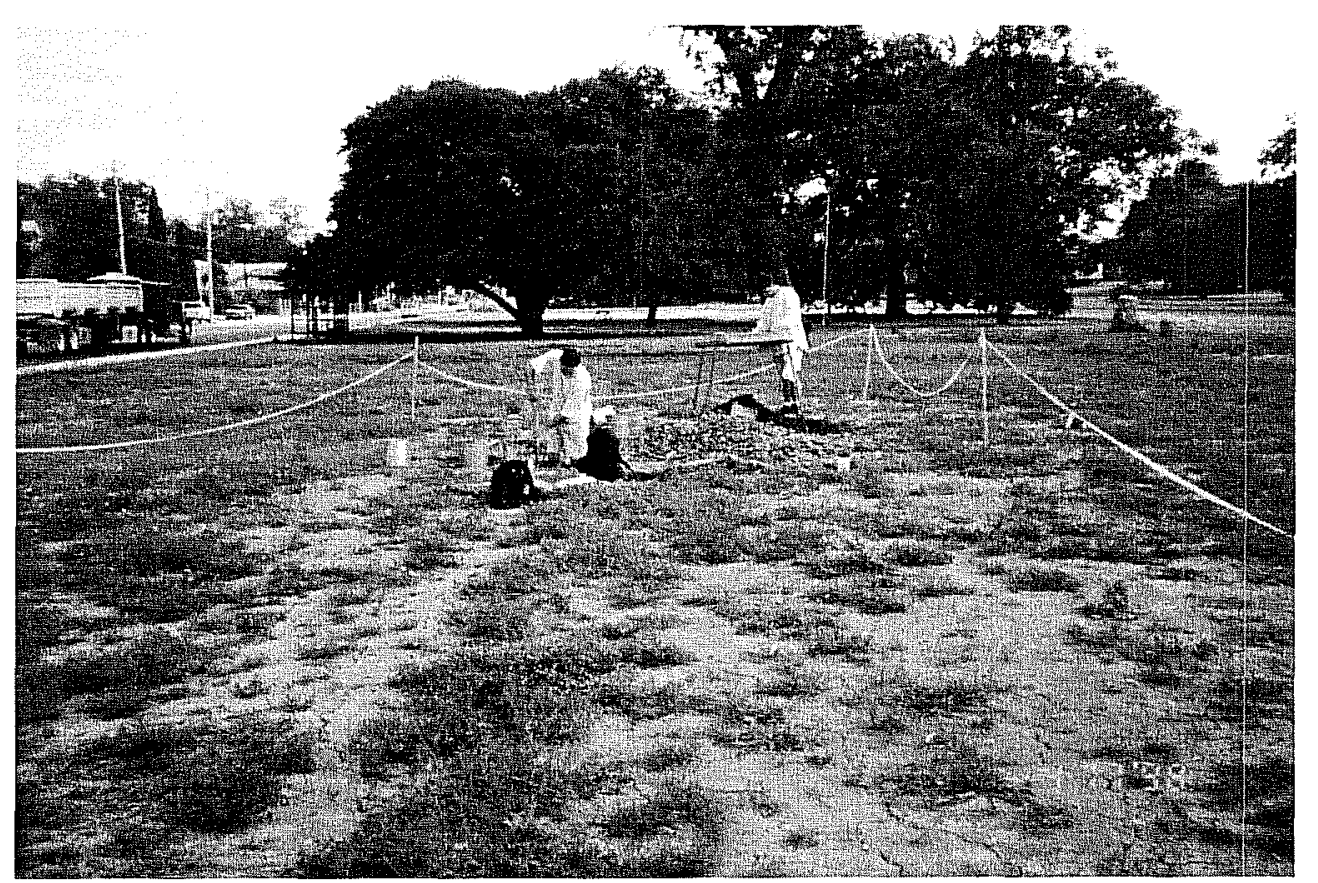

Figure 3. Red sandy loam on a portion of the ground surface of the park.

Looking north. 
Barbara A. Meissner served as the project archaeologist for the 1996 testing project. CAR crew members were I. Waynne Cox, David Cruz, Jeff Francis, Edgar Johnson, Preston McWhorter, and Andrew Scease. Lisa Durack, a volunteer from the Southern Texas Archaeological Association (STAA), also assisted in the field. Anne Fox assisted with the lab work, and Andrew Scease conducted a portion of the artifact analysis. Brett A. Houk served as the project archaeologist for the 1998 testing project. CAR crew members were Donna Edmondson, Owen Ford, Kevin Hanselka, Chris Horrell, Kimberly Kvernes, Tony Lyle, Bruce Moses, and Ruth Mathews.

This report documents the methods and results of Meissner's work in 1996 and Houk's first project in 1998, both sponsored by SARA. A third archaeological testing project was sponsored by the City of San Antonio Parks and Recreation Department, and was conducted by CAR later in 1998 (Houk's second project) in conjunction with planned improvements to the park's infrastructure. The archaeological testing program for the infrastructure plan is reported separately in CAR's Archaeological Survey Report, No. 289 (Houk 1999).

The remainder of this chapter will describe the site setting and previous work in and near the park area. Chapter 2 offers a culture history of the park. Chapter 3 presents the methods, results, and recommendations of the 1996 investigations conducted by Meissner along the western edge of the park. Chapter 4 includes the methods, results, conclusions, and recommendations of the 1998 impact assessment project directed by Houk in the southwest corner of the park. A detailed plan for managing the cultural resources in the park is presented in Chapter 5. And, supporting data are included in several appendices.

\section{Site Description}

San Pedro Park is located in downtown San Antonio, with Ashby Street to its north, San Pedro Street to its east, Myrtle Street to the south, and North Flores Street to the west of the park. Located within the park, San Pedro Springs are comprised of at least eleven major and numerous minor springs, and are one of the many outlets of the Edwards Aquifer, which receives its recharge from the hills north of the town (Brune 1981:73). Until modern pumping practices lowered the level of the Edwards Aquifer, the flow of water into San Pedro Creek averaged about 200-250 liters per second (Figure 4). Unfortunately, the springs in San Pedro Park today are completely dry (Figure 5), except after heavy rains, when they briefly flow again.

\section{Modern Environment}

The city of San Antonio has a modified subtropical climate, with cool winters and hot summers (Taylor et al. 1991:118). Average temperatures range from $62.3^{\circ} \mathrm{F}$ in January to $94.2^{\circ} \mathrm{F}$ in August (Taylor et al. 1991: Table 11). Rainfall averages 27.89 inches but there is a great deal of variation from year to year (Norwine 1995:139). The growing season averages 275 days (Taylor et al. 1991:119).

Soils from three series occur in San Pedro Park (Taylor et al. 1991:Map 44). The northeastern quarter has a Tarrent association soil. These soils are typically

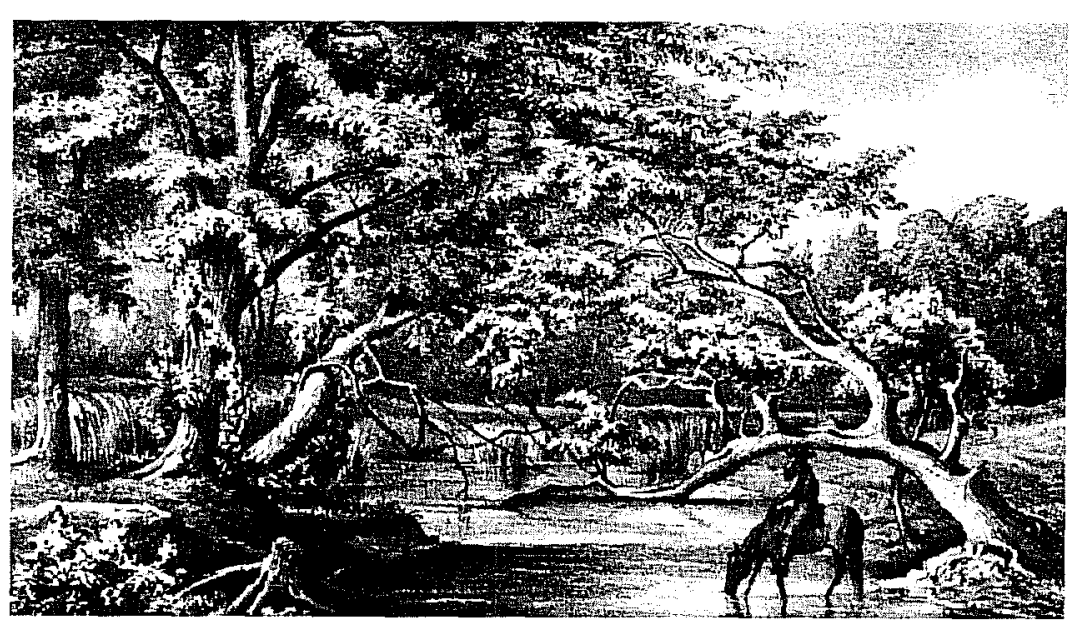

Figure 4. San Pedro Springs, Herman Lungkwitz drawing ca. 1850. (Photograph in the collection of the Institute of Texan Cultures, San Antonio, Texas. Used with permission.) found on hilly areas and are dark colored, very shallow, clayey, and weakly calcareous (Taylor et al. 1991:31). In the northwestern corner of the park Austin silty clay soil is found. This soil is encountered on low, broad ridge tops. It is 
Figure 5. The main spring of San Pedro Springs, San Pedro Park, in July 1996.

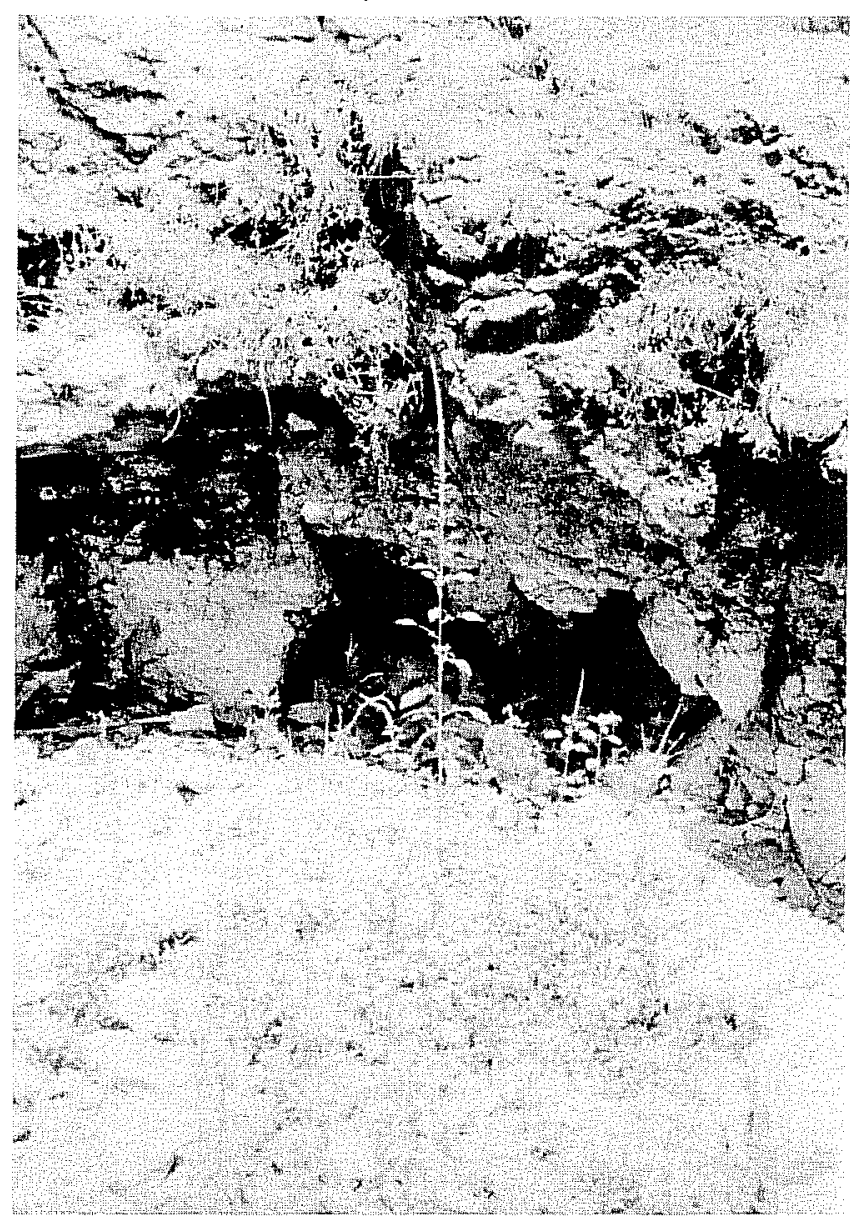

moderately deep, dark colored, and highly calcareous (Taylor et al. 1991:10). The rest of the park is covered with Houston Black clay terrace soil. This soil is a thick, dark, calcareous clay common on terraces near major streams (Taylor et al. 1991:21).

Bexar County is located at the juncture of several major biotic and physiographic regions, providing a diverse and dynamic biological setting. Potter et al. (1995:23) notes the presence of five biotic zones in the county. The northernmost is the Oak-Juniper Woodland, which covers the southern edge of the Balcones Escarpment, a fault zone cutting across the northern half of the county (Potter et al. 1995; Taylor et al. 1991:119). This region has been described as "canyonlands" (Potter et al. 1995:13), heavily dissected by numerous creeks and springs. Tallgrass prairie once covered the area immediately below the escarpment. This is the southwestern-most extension of the Blackland Prairie physiographic region. An area of dense brush country forms a narrow band between the tallgrass prairie and the Oak-Hickory Forest of the southernmost section of the county, which is the northeastern boundary of the South Texas Plains (also called the Rio Grande Plains and the Tamaulipan biotic province [Blair 1950]). The fifth biotic zone is the riparian forest which cross-cuts all the other zones in the creek bottoms and around springs (Potter et al. 1995:23).

Each of these zones contains a somewhat different set of plant and animal communities, making the area an ecotone, and providing a wide diversity of resources (Collins 1995; Ellis et al. 1995; Nickels et al. 1997:4; Potter et al. 1995:13). Pecan (Carya illinoisensis), hickory (Carya sp.), walnut (Juglans sp.), and acorns (Quercus sp.) would have been plentiful in the latesummer and fall, as would deer (Odocoileus virginianus), turkey (Meleagris gallopavo), and (at least by the Late Prehistoric period) javelina (Pecari tajacu) (Hulbert 1985; Potter et al. 1995:13; Tomka et al. 1997a). In upland regions, yucca (Yucca sp.), sotol (Dasylirion sp.), and prickly pear cactus (Opuntia sp.), the latter a year-round resource, were available. Rabbits, both cottontail (Sylvilagus sp.) and blacktailed jackrabbit (Lepus californicus), were an important resource (Tomka et al. 1997a; 1997b). Turtles and small fish were available in the creek bottoms (Meissner et al. 1998; Tomka et al. 1997a).

In addition to plentiful water and plant and animal resources, the region provided an important mineral resource-chert. Large quantities of high-quality chert eroded out of the limestone along ridges on the Balcones Escarpment, and the chert-bearing Uvalde gravels were available in the more southern parts of the county (Loomis et al. 1992; Nickels et al. 1997; Potter et al. 1992).

\section{Paleoenvironment}

Understanding the environment within which people live is crucial to interpreting their cultural adaptations. Unfortunately, there is only enough paleo-environmental data available to make very broad guesses about the climatic changes the area around San Antonio. An extensive discussion of current research on the 
subject is available in Tomka et al. (1997a). Briefly, the Late Pleistocene environment was much cooler and wetter than today (Bryant and Holloway 1985:50). There is considerable disagreement about whether the change to the modern climate was a slow, steady warming and drying trend (Bryant and Shafer 1977:15-19), or was much more variable, with numerous fluctuations between relatively wet and dry periods throughout the Early and Middle Holocene, with the driest period occurring between about 4000-6000 B.P. (Bousman 1994; Gunn and Mahula 1977). Evidence for a cooler, more mesic period about 2500 B.P. is fairly consistent, with dry periods at about 1600 to 1500 B.P. and 500 to 400 B.P. (Bousman 1994:80, 1998; Tomka et al. 1997a).

Within the Historic period, records allow a more finegrained examination of the climate. Norwine (1995:139) notes that the climate of South Texas is considered unusual or even unique among semi-arid environments. The extreme variability of rainfall and temperature, which exhibits very little in the way of periodicity or trend, has had considerable if temporary effect on the plant and animal communities in the region (Norwine 1995:139-140). However, a recent connection between the El Niño event in the South Pacific and wet, cool years in Texas has been identified (Stahl and Cleaveland 1995:60), and traced back 300 years in tree ring data (Stahl and Cleaveland 1993).

In addition to natural fluctuations in biotic communities, man-made changes have occurred as well. Euro-American land-use and water-use practices of the last 200 years have led to extensive changes in the plant and animal communities in the area around San Pedro Springs.

Overgrazing and the control of wild fires have resulted in an expansion of brushy species, especially mesquite (Prosopis glandulosa), blackbrush acacia (Acacia rigidula), whitebrush (Aloysia gratissima), and huisache (Acacia smallii), from the mottes that they once inhabited to dominate both the tallgrass prairie and the chaparral regions of the county (Inglis 1964). Pumping water from the Edwards aquifer has depleted many springs and transformed once permanent or semi-permanent streams into dry ditches which flow only when there are heavy rains (Brune 1981).

\section{Geology}

Bedrock formations exposed at San Pedro Park are Austin Chalk, Pecan Gap Chalk, and Upper Taylor Marl (Barnes 1974; Drash-Focht Consulting Engineers 1995). These formations are all Upper Cretaceous deposits. The oldest is Austin Chalk, which occurs in a triangular section extending from the northeast corner of the park to the southwest side at the intersection of Hickman and North Flores streets (Figure 6). The Pecan Gap Chalk occurs only in the northwest corner of the park and the Upper Taylor Marl covers most of the southern half of the park. The Austin Chalk is a block of upfaulted deposits, and the fault on its south side with the Upper Taylor Marl created San Pedro Springs. A cross-section of geotechnical boreholes shows that the upper clay deposits on the west side of San Pedro Park increase in depth to the south,

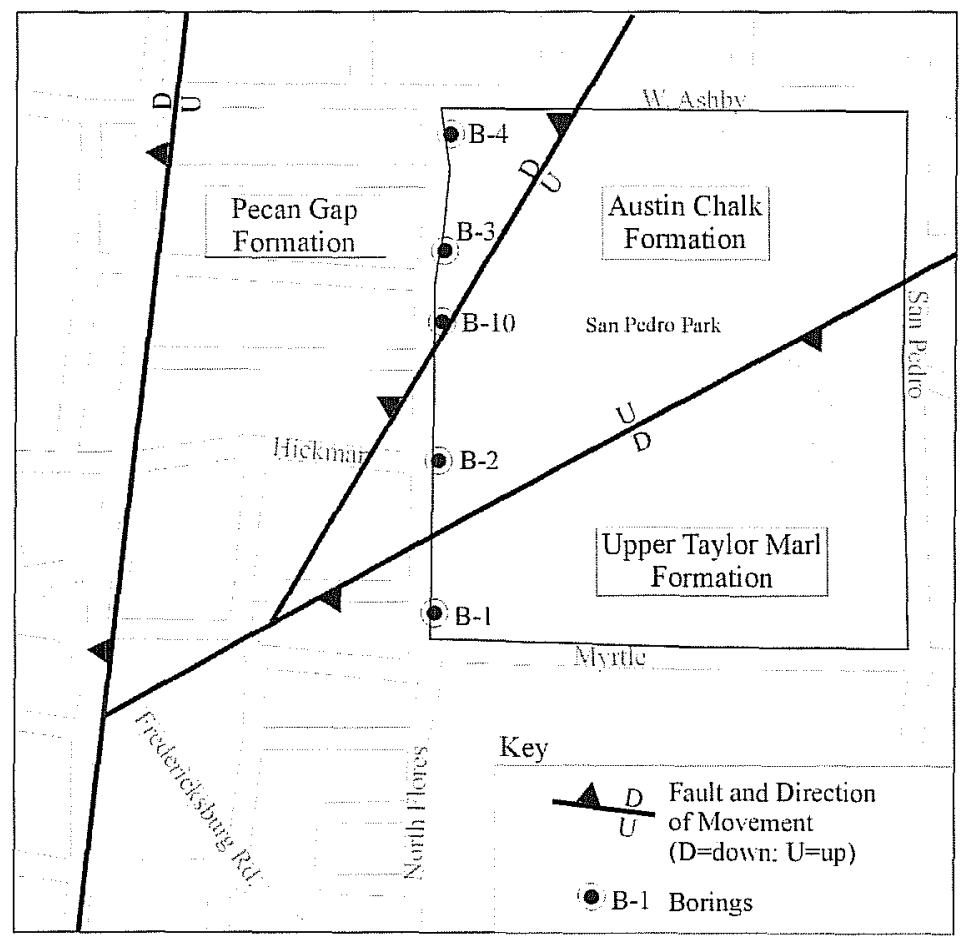

Figure 6. Park map showing bedrock formation, faults and location of geotechnical bore holes.

Adapted from Drash-Focht Consulting Engineers, 1995. 
Figure 7. Profile of boreholes along western edge of the park. Adapted from Drash-Focht Consulting Engineers, 1995.

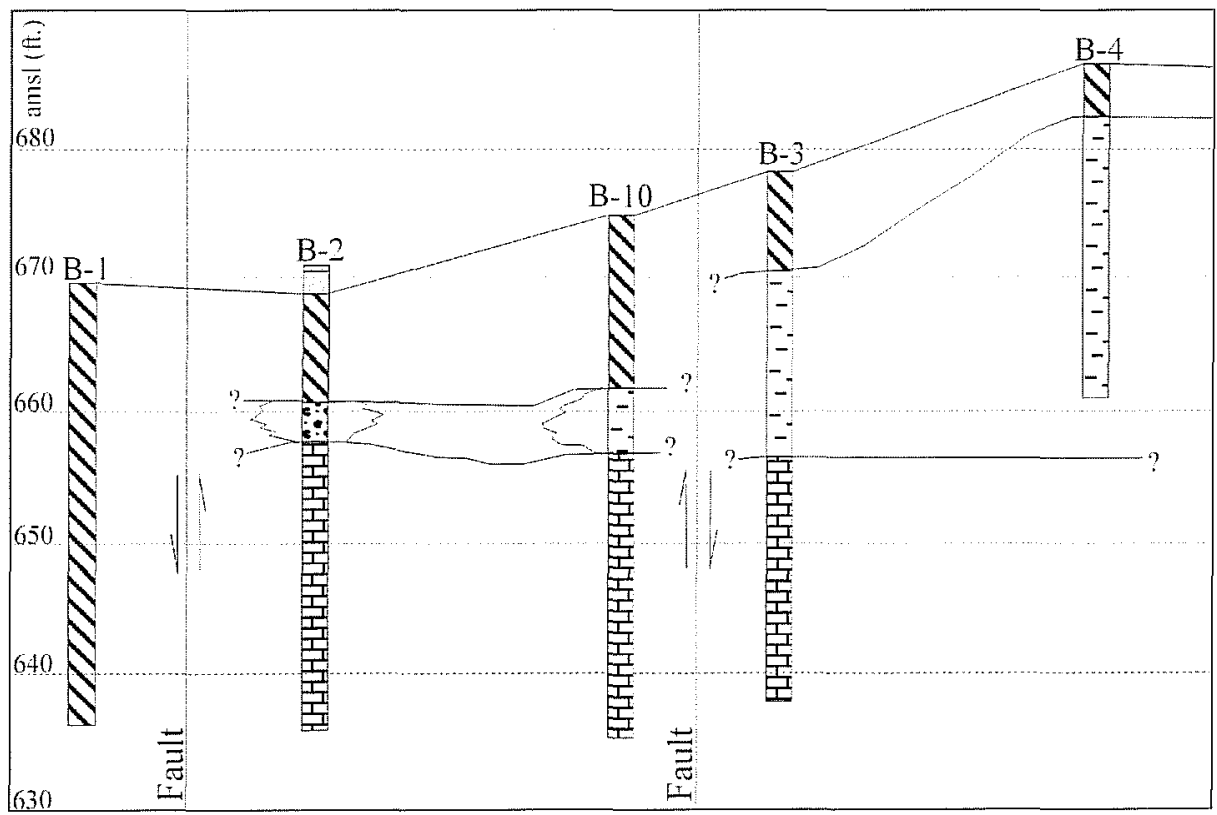

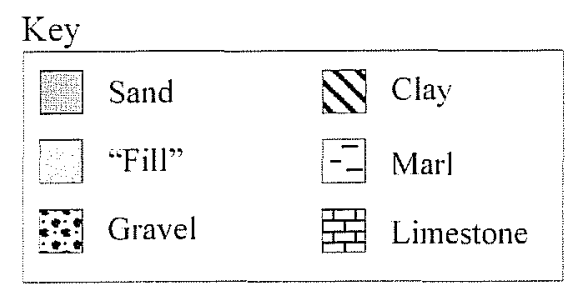

and especially south of each fault (Figure 7). The surface and bedrock topography, along with the general geological setting, strongly suggest that colluvial deposition played a major role in the accumulations of the surface clays.

Although the area around San Pedro Springs has a rich and varied cultural heritage, little archaeology has been conducted within the Park. Surface collections indicate occupation of the springs in the San Antonio River valley since the Late Pleistocene (Fox 1975; Orchard and Campbell 1954). In 1977 CAR conducted limited excavations on a portion of the Alazán Acequia in the area to the east and south of the main springs (Fox 1978). Fox's excavation revealed a two-phase construction sequence. Fox has also noted other structures of possible historic or cultural value within the park (Fox 1979). Her excavation was the only professional excavation known to have taken place within the park itself until the testing project began in 1996 .
In 1985 archival and archaeological investigations were conducted on nearby portions of the San Pedro acequia and a search was conducted for traces of the Arocha Acequia south of the park (Cox 1986). A section of the Alazán acequia was exposed and documented in the area of South Frio Street (Labadie 1987).

In 1989 SARA contracted with CAR to identify cultural resources associated with the anticipated channel improvement for San Pedro Creek in the area located just south of San Pedro Park, the Five Points intersection, and southward towards Interstate Highway 10 . An archival and historic research report was published which identified potentially sensitive areas within the project area (Uecker 1991). During a channel improvement project in 1996, the Alazán acequia was encountered at the intersection of Cornell Street and Fredericksburg Road. This section of the acequia was documented in a report produced by CAR (Nickels and Cox 1996). 
Figure 8. Map showing modern streets and location of three acequias in the vicinity of the park.

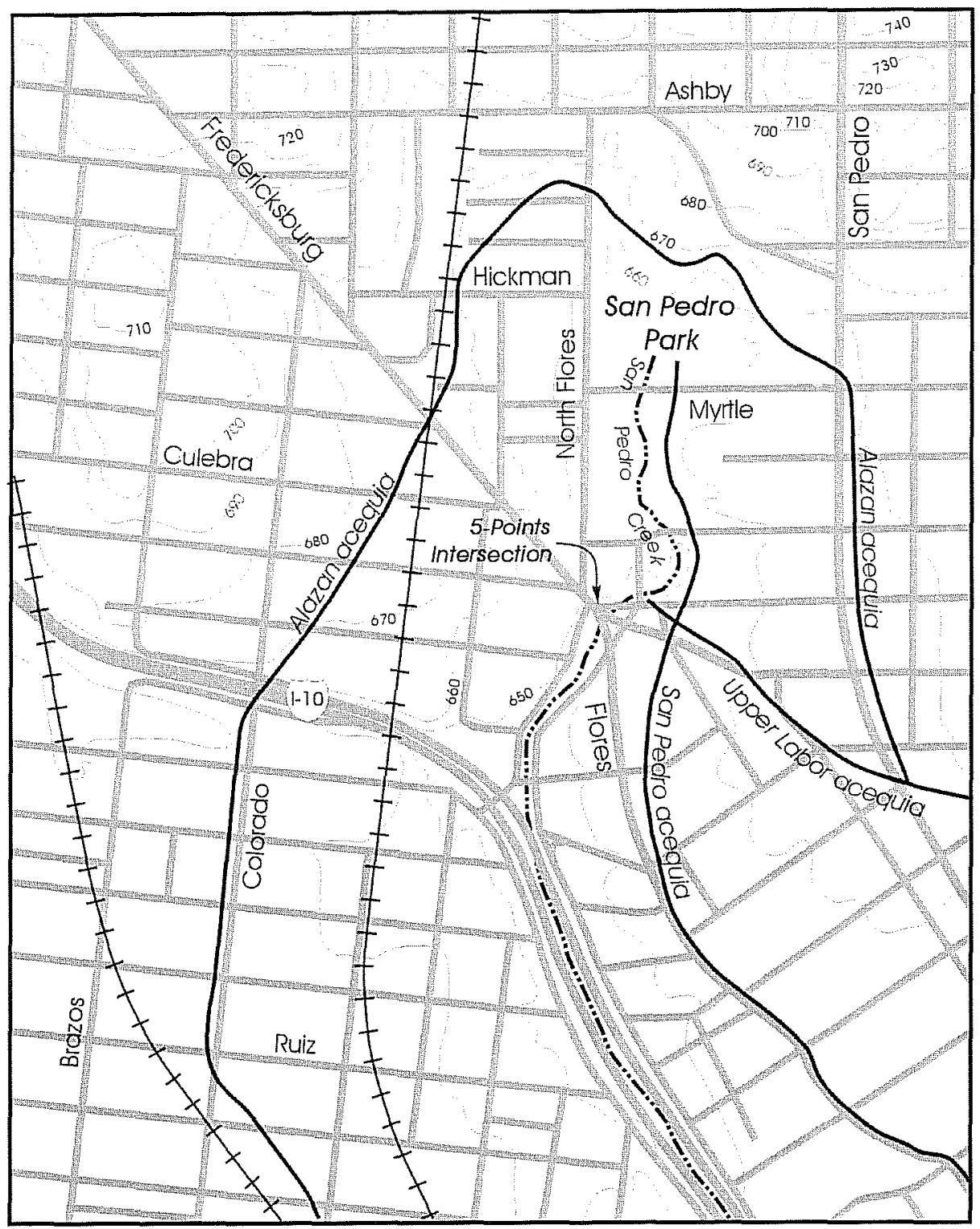

Portions of three acequias that run through or very near the park (Figure 8) have been archaeologically examined: the San Pedro, the Upper Labor, and the Alazán. In 1985, archival and archaeological investigations were conducted on portions of the San Pedro acequia, and the old ditch was found one block south of the park (Cox 1986). In 1977, CAR conducted limited excavations on a portion of the Alazán acequia in the park to the east and north of the main springs (Fox 1978). During the construction of a water and sewer line by SARA, Nickels and Cox (1996) again documented the Alazán acequia at the intersection of Cornell Street and Fredericksburg Road, two blocks west of the park.

Most recently, Houk (1999) conducted backhoe, and shovel tests in the much of the central area of the park. This project found discrete areas with prehistoric cultural deposits that were still intact despite alterations that have occurred in historic times. 


\section{Chapter 2: Historic Background}

\section{Barbara A. Meissner}

\section{Prehistoric Context}

Native Americans have exploited the resources of the San Antonio River valley over the past 11,000 years (Black 1989, Orchard and Campbell 1954). Archaeological research has divided this long period into a few very general intervals, presented in Table 1. More detailed discussions of the prehistory of South and Central Texas are available in Collins (1995), Hester (1995), and Hunziker et al. (1997).

The archaeological evidence shows that Native Americans in the San Antonio area were hunter-gatherers who lived in small bands. As discussed in Chapter 1, the region is an ecotone, with a wide range of resources for its inhabitants. The many springs, creeks, and rivers in the area provided plenty of water, even in times of drought. In addition to food resources, the area contained large quantities of high-quality chert. Together, these resources made the San Antonio River valley a favorable location for hunter-gathers. There is no evidence that, prior to the coming of the Spanish, the inhabitants of the San Antonio valley ever become farmers, unlike their neighbors living to the east. As Collins (1995:387) states,

$$
\begin{aligned}
& \text { "efficient technologies for hunting } \\
& \text { and gathering prevailed and... }
\end{aligned}
$$

the plant and animal resource base was both rich and diverse. Central Texas was

one of those places in the world where the labors and limitations of food production could be looked upon with disdain."

\begin{tabular}{|c|c|c|}
\hline Interval & Approx. Dates (BP) & Characteristics \\
\hline Paleoindian & $11200-8000$ & $\begin{array}{l}\text { This period is not well understood. It was previously assumed to be largely focused on } \\
\text { hunting big game, but is now believed to have included a variety of smaller game as well } \\
\text { as plant foods. Most known sites are on upland settings (valley margins, terraces, etc.) but } \\
\text { a few deeply buried sites have been found in valley bottoms (Hunziker et al. 1997:2-3). } \\
\text { Typical projectile points include Clovis, Folsom, and Plainview projectile points in the } \\
\text { early period and Golondrina and Angostura in the later period. }\end{array}$ \\
\hline $\begin{array}{c}\text { Early } \\
\text { Archaic }\end{array}$ & $8000-5000$ & $\begin{array}{l}\text { The emphasis is presumed to have shifted from now-extinct large gregarious herbivores } \\
\text { to deer, smaller mammals, and increased use of plant foods, but little direct subsistence } \\
\text { data is available due to poor preservation of flora and faunal remains (Hunziker, et al. } \\
1997: 2-3) \text {. Sites are generally on terraces near water. There is a shift to more regional } \\
\text { projectile point types. Projectile points include Uvalde, Martindale, Baker, Bell and } \\
\text { Andice points, and probably the distinctive Guadalupe biface. }\end{array}$ \\
\hline $\begin{array}{l}\text { Middle } \\
\text { Archaic }\end{array}$ & $5000-2400$ & $\begin{array}{l}\text { There is apparently an increase in emphasis on intensive use of vegetal resources, as } \\
\text { evidenced by the very common presence of large accumulations of burned rock, as well } \\
\text { as manos, and metates (Hunziker et al. 1997:2-4). Sites are on knolls and bluffs along } \\
\text { stream channels. Most common projectile points include Pedernales, Langtry, Kinney } \\
\text { and Bulverde. Tortugas, Morhiss and Lange points appear late in the period. The first } \\
\text { large cemeteries appear in this period. }\end{array}$ \\
\hline $\begin{array}{c}\text { Late } \\
\text { Archaic }\end{array}$ & $2400-1150$ & $\begin{array}{l}\text { Sites are usually found near water sources and occur in all topographic settings. } \\
\text { Subsistence appears to have been more broadly based, exploiting a wide range of plant } \\
\text { and animal resources. Burned rock middens are less common, but manos and metates } \\
\text { remain common. Projectile points include Corner-tang bifaces, Montell, and Marcos } \\
\text { points. In the later part of the period, Ensor and Frio points are common. }\end{array}$ \\
\hline $\begin{array}{c}\text { Late } \\
\text { Prehistoric }\end{array}$ & $1150-350$ & $\begin{array}{l}\text { There is a shift to bow-and-arrow and the beginning of ceramic technology. Edwards and } \\
\text { Scallorn points are diagnostic. At about } 600 \mathrm{~B} \text {. P. there is a distinct shift to contracting } \\
\text { stem arrow points such as Perdiz and use of alternately beveled bifaces, associated with } \\
\text { an increase of bison bones in archaeological sites. }\end{array}$ \\
\hline
\end{tabular}

Table 1. Prehistoric Cultural Intervals (based on Hunziker et al. 1997) 
The largest group described by early Spanish visitors to this region was the Payaya, whose apparent territory extended from the San Antonio valley to the southwest for at least 40 miles (Campbell and Campbell 1985:37). The diary of the Terán expedition mentions them on the San Antonio River in 1692 and describes them as "docile and affectionate, and naturally friendly" (Hatcher 1932:14). The diary of Gregario de Salina Verona mentions visiting a settlement of Payaya at San Pedro Springs in 1693 (Foster and Jackson 1993). They are believed to have been speakers of a Coahuiltecan language (Goddard 1979:366-367). Unfortunately, the Spanish were more interested in changing Native American lifeways, than recording them (Campbell 1975:1). What little they did describe was incidental to other matters and biased by their ethnocentrism.

Ethnographic evidence gives us some information about the Native Americans living here in the early eighteenth century, but it would be a mistake to believe that the lifeways described by the first Spanish visitors to Texas were identical to the long-successful adaptations of their ancestors (Campbell 1975:1). In the 150 years before the first Spanish settlement in the San Antonio Valley, the Native Americans of South and Central Texas had undergone serious disruptions as a result of an influx of groups fleeing the disturbances caused by the Spanish in northern Mexico and New Mexico, and possibly by the European diseases that were spreading through the area in the latter part of the seventeenth century (Ricklis 1996:131-132). These displaced groups were "often fragmented, and their populations declined" (Campbell and Campbell 1985:1).

\section{Historic Period}

\section{Waynne Cox}

\section{The Spanish Colonial Period}

San Pedro Springs was first given a European name by Antonio de San Buenaventura de Olivares and Isidro Felix de Espinosa in 1709. Fray Espinosa, the diarist of the expedition, recorded, dimos en una acequia de agua muy poblada de arboles que era suficiente para un pueblo, y toda liena de tomas de aqua estar alta la acequia y colgadas las tierras pusimosle por nombre el aqua de S. Pedro

[Foster 1995:99].

This passage was translated by Father Gabriel Tous (1930:5) as,

$$
\begin{gathered}
\text { "We came to an irrigation ditch, bordered by many } \\
\text { trees and with water enough to supply } \\
\text { a town. It was full of taps and sluices of water, } \\
\text { the earth being terraced. } \\
\text { We named it San Pedro Springs." }
\end{gathered}
$$

Tous's use of the phrase "irrigation ditch" to translate the Spanish acequia is understandable, as this is the current usage of the word. This translation has led some (see Foster 1995:99) to believe that either the indigenous population was already farming in the valley when the expedition arrived or that earlier Spanish settlers already were present. There is no evidence for either interpretation in any other text, or in the archaeological record. In fact, later in the same diary, Espinosa says nothing about an acequia, but mentions that San Pedro Creek was "sufficient for a mission" (Tous 1930:9). It seems reasonable to translate the word acequia in the above quoted passage as either "stream" or "creek."

In April 1718, the newly appointed Governor of Coahuila, Martín de Alarcón, crossed the Rio Grande with an entrada of seventy-two persons intent upon establishing a way station between the Rio Grande and the East Texas missions. On May 1, Alarcón selected an area near the San Pedro Springs for the location of his new presidio (Hoffman 1935:49). This constituted the founding of what would later become the city of San Antonio. Beside the presidio, the first mission - San Antonio de Valero, to gain fame in its present location as the Alamo- was established. Neither site's location was exactly recorded but both were in the vicinity of the springs, probably located on the higher ground to the northeast (the presidio) and to the south (the mission). 
One of the diarists of the expedition described San Pedro Springs...

$$
\begin{aligned}
& \text { "This place in which we find ourselves is } \\
& \text { pretty because of the trees that it has at its spring. } \\
& \text { The water is sweet and very fine... } \\
& \text { The trees which the wood contains consist } \\
& \text { of pecans, mulberries, elms, and poplars, } \\
& \text { and there are also many grapevines" }
\end{aligned}
$$$$
\text { (Hoffman 1938:317). }
$$

In January 1719 , an acequia was constructed to serve the needs of the presidio and its small contingent of families. In 1722, the new Governor, Marquís de San Miguel de Aguayo, learned that a raging fire had swept through many of the frail structures of the presidio of Béxar. Sixteen of the soldiers' huts had been destroyed and others damaged. Worst of all, the granary, with 700 bushels of corn and all of the flour, had been lost. He immediately ordered that a new presidio be built, this time of "fire-proof" adobe. The new presidio was to be constructed farther to the south at the big bend of the river opposite the new site of Fray Olivares's mission (Chipman 1992:125).

In 1724 Brigadier Pedro de Rivera y Villalon was dispatched by the viceroy to inspect and evaluate the frontier defenses of New Spain. The tour lasted until June 1728 and covered over 8,000 miles. Among his recommendations were the reduction of the East Texas garrisons and the relocation of the three missions there to new sites on the Colorado River, near present-day Austin. Viceroy Antonio de Aviles, the Marquís de Casafuente, acting on the recommendations, reduced the presidios and moved the missions in July 1730 . That location was not acceptable to Father Paredes, the guardian of the founding college of Querétero, and the missions were again moved, this time to the San Antonio River valley on March 5, 1731.

Another recommendation of Brigadier Rivera was that the frontier be settled with stable families, believing that "one permanent Spanish family would do more to hold the country than a hundred soldiers" (Chabot 1937:141). On March 9, 1731, 56 settlers from the Canary Islands arrived at the presidio to form the nucleus of the Villa of San Fernando de Bexar, the first civil settlement of Texas. The king awarded this new settlement the right to eight leagues of land as a town tract, with the land outside of the villa to serve as ejido or public land (Corner 1890:36). The springs of both San Pedro Creek and the San Antonio River were within this public land.

As the villa grew, so did the demand for public land that could be irrigated. In August 1762, a group of 13 citizens petitioned the governor for land and water to be distributed as previously ordained. In their request, they claimed that "about the year of forty-five" the viceroy had ordered the previous governor to distribute the lands, but for unknown reasons, he had failed to comply. The governor, Angel de Martos y Navarrete, agreed that the request was valid and directed Geronimo Flores, who was "skillful in withdrawing water," to measure the lands proposed for the acequia. Flores reported that a channel could be constructed from a point on the river 5,853 varas (three miles) north of the villa that would pass through 5,000 varas (4428.4 acres) of irrigable land. The only obstruction that presented itself was a stretch of 150 varas (416.6 $\mathrm{ft}$ ) "across the brow of the hill which is called 'Loma de la Vieja"" (now known as Tobin Hill, to the immediate northeast of the park; Bexar Archive Translations, "Citizens to Navarrete," August 1762). The governor fully agreed with the proposal and submitted it to the viceroy, but for reasons unrecorded, the plan was not put into effect. Fourteen years later, citizens again petitioned the governor, Baron de Ripperda, for the additional land and water. The reason for this renewal of interest may have arisen from the fact that the villa was in the depth of a severe drought which began in 1771 and lasted for six years (Gunn et al. 1982:70).

Having satisfied himself that neither the villagers nor the clergy were against the project, the governor ordered that by January 29, 1776, all "resident Islanders and others present themselves before me, and those who wish to contribute to said ditch, therefore after having enlisted themselves, to commence same, each to commence with one peon and the necessary tools" (Corner 1890:20). Construction on the acequia began in July 1776, and by April 28, 1777, the acequia had reached the midpoint of its construction. To render the ditch operational for the planting season, the ditch was returned to the river, and a drawing was held to distribute the first 26 suertes, containing some 25,230 
varas of land. (Spanish Archives [SA], Office of the Count Clerk, Bexar County Courthouse, Volume 3:318-332). By March 1778, the remaining portion of the acequia was finished, "draining into the San Pedro Creek by a trough . . . so that the residents located on the other side may avail themselves of its excess," and the drawing procedure was repeated to distribute the remaining suertes of land. One exception was that Francisco Xavier Rodriguez did not take part in the drawing. He had agreed to take a suerte and a half to the north of the ditch (SA Volume 3:327). The suerte selected by Rodriguez was described as:

"measuring 471 varas [1308.3 ft] from the aqueduct or trough of the upper labor ditch up said ditch in a direction east to a point where it forms an acute angle, thence running west 281 varas $[780.5 \mathrm{ft}]$, thence down the San Pedro Creek to the trough which crosses it for the drainage of the upper ditch 249 varas [691.6 ft], thence with said ditch to place of beginning" [City Council Minutes (CCM), Office of the City Clerk, City Hall, Volume C:194].

The aqueduct referred to first was located where the new ditch, the Upper Labor, crossed an ancient acequia for the Labor Alta de Santa María. The latter began at the springs and flowed along what is now San Pedro Avenue to the point mentioned (near the intersection of Maverick and Warren streets). From that point the old acequia joined the Upper Labor and ran to a point near Howard and Euclid streets, where it turned southeast to the west of Richmond Avenue and returned to the river at St. Mary's and Arden Grove (SA Volume 2:474, Volume 3:333; Institute of Texan Cultures, "Abstract Block 31, City Block 302," Stewart Title Company Collection). This ancient acequia is, most probably, the original channel excavated for the first site of the presidio near the springs (Cox 1987:2-3).

The Rodriguez grant encompassed the lower portion of what is now San Pedro Park. His descendant, Judge José María Rodriguez, claimed that Francisco had established a trading post upon the grant (Rodriguez 1961[1913]:24). On August 26, 1778, Vincente Flores requested and was granted the vacant land to the north of the Rodriguez tract (SA Volume 2:474). In June
1784, Don Francisco Arocha submitted a complaint to Governor Cabello charging that Vincente Flores and Francisco Xavier Rodriguez had failed to comply with the conditions of their grants by "not keeping their fences in good order" (CCM Volume C:194; City Right-of-way Office, Main Plaza Building, "ROW File, NCB 996," abstractor's note). The original owners were then dispossessed and the lands awarded to Arocha (CCM C:194, abstractor's note). Francisco Arocha's heir, José Nepomuceno Arocha, conveyed 177 acres "adjoining the little spring" to Alfred J. Shelby, who in turn, transferred the property to Samuel Augustus Maverick on December 5, 1846 (Bexar County Deed Records [BCDR], Bexar County Courthouse, Volume D2:171).

The northeast corner of what now constitutes San Pedro Park served as the closest hard-limestone quarry to the city until well into the nineteenth century. Although the exact date of the beginning of the quarry has not been determined, its proximity to the city may indicate Spanish colonial use. The limestone was removed from the high margin of exposed stone that extended into what is now known as Tobin Hill.

\section{San Pedro Park in the Nineteenth Century}

As a result of the annexation of Texas in 1845, disputes between Texas and Mexico that had been growing since the establishment of the Republic of Texas came to a head, and Mexico broke diplomatic relations with the United States. Anticipating the outbreak of hostilities, Brevet Colonel William Selby Harney, with three companies of the 2nd Dragoons, was dispatched to San Antonio as the vanguard of Brigadier General John Wool's Chihuahua Campaign (Cutrer 1996:3:466). Due to a lack of adequate quarters in town, a camp was established at the springs and named "Camp Crockett" (Bauer 1974:144-146; Smith 1963[1919]:I:270). Anxious to secure a permanent military presence, the city offered the land at the springs to the army, but the federal government refused on the grounds that the land was unhealthy and subject to attack from the high ground nearby (Crook 1967:26; Peyton 1946:85). The area later served as a campground for John Russell Bartlett's retinue before their departure to survey the limits of the territory acquired as a result of Mexico's defeat (Bartlett 1965:38). 
As early as 1847 , the city of San Antonio had sought to reclaim those lands to which it felt entitled under the now-missing Spanish grant. After many years in court, the case was decided in favor of the city and the entire eight leagues of land was awarded to the municipal government (Texas Supreme Court 1857:287-321). The city then took action to evict those it considered trespassers and sold off some of the lands to balance the city budget. At that time the city surveyor, François Giraud, was instructed to define the public park. Giraud completed his survey and reported to the city council:

"I have the honor to report for your consideration the following reserves to be made by your honorable body on the city property . . . at the head of the San Pedro Creek, a square around the springs . . . being 518 varas [1438.8 ft] from east to west and 550 varas $[1527.7 \mathrm{ft}]$ from north to south"

[CCM B:191].

The park was officially dedicated as a public square on November 6,1852 . Although various individuals would contest the city claim for the next 58 years, the boundaries have remained unchanged to the present (BCDR S1:280, U2:574, W2:312, 344:432).

During the ensuing years, the springs became increasingly popular as a place for public activities. In September 1854 , a two-day county agricultural fair was held there (Crook 1967:27). The park was also the scene of a heated political rally staged for Governor Sam Houston during his unpopular campaign to defeat secession (Alamo Express [AE], 8 October 1860). After his efforts proved to be unsuccessful, the park served as the containment area for the federal troops after the surrender of General Twiggs (War of the Rebellion 1901:VII:572-574).

When the city dedicated the park, there was an occupant residing on the land without legal title, John Jacob Duerler. Duerler and his wife Elizabeth had immigrated from St. Gallen, Switzerland, in 1849 (Steinfeldt 1978:94). Duerler leased a portion of the land from the city, "all that portion of the public square of the San Pedro Creek, now covered by buildings or enclosures occupied by me, and said buildings being about 70 or 80 varas (195 to 222 feet) east of the San Pedro
Springs" (BCDR Volume R1:443). This seems to indicate that Dueler was the occupant, if not the builder, of the "old fort" that stands today in the eastern portion of the park. During the period 1851-1864 the control of the park is unclear. Other than Duerler, William Muller and a Captain Stitch, at various times, advertised themselves as proprietors of the amusements at the springs. Finally, in March 1864, Duerler entered into a 20-year lease with the city for the exclusive operation of the concessions in the park. During the next decade, Duerler constructed five fan-shaped artificial lakes to the west of the natural lake at the head of the creek and stocked them with plants and colorful fish (Figure 9). These were shallow and fed by the several natural springs within the park (Allen 1993). He created a private museum and a collection of animals that was credited as being "the largest zoological collection in the South" (San Antonio Express [SAE], 18 March 1900). With the addition of a traveling animal show which became stranded in the city near the turn of the century and was later purchased by the city council, Duerler's collection became the core of the San Antonio Zoo, which later moved to Brackenridge Park (San Antonio Light [SAL], 3 July 1949). Duerler also added a race course, an exhibition building, a ballroom, a tropical garden, and a lucrative and popular beer garden (Gould 1882:133).

In May 1874, the city council directed that work on the Alazán Ditch begin. The Alazán Ditch was a channel designed to provide both irrigation to the developing west side of the city beyond San Pedro Creek and flood relief from the storm waters of Olmos Creek that had often troubled the city (CCM Volume D:118; City Ordinance JD 372). The concept of the new acequia developed after a massive flood in the downtown section of the city in March 1865 . The committee appointed to investigate the causes recognized that a major contributing factor was the substantial amount of water collected within the Olmos basin, then some five miles north of the city. The city engineer developed plans to divert this water away from the downtown area (CCM, C:475). Two years later, city engineer F. Giraud proposed diverting the flood waters of Olmos Creek to the Alazán Creek to the far west and south side of the city (CCM, Volume C:577, 583). No action was taken on the proposal at that time, no doubt due to the cost and complexity of the 
Figure 9. Map of San Pedro Park drawn in the 1870s.

Dark patches are springs.

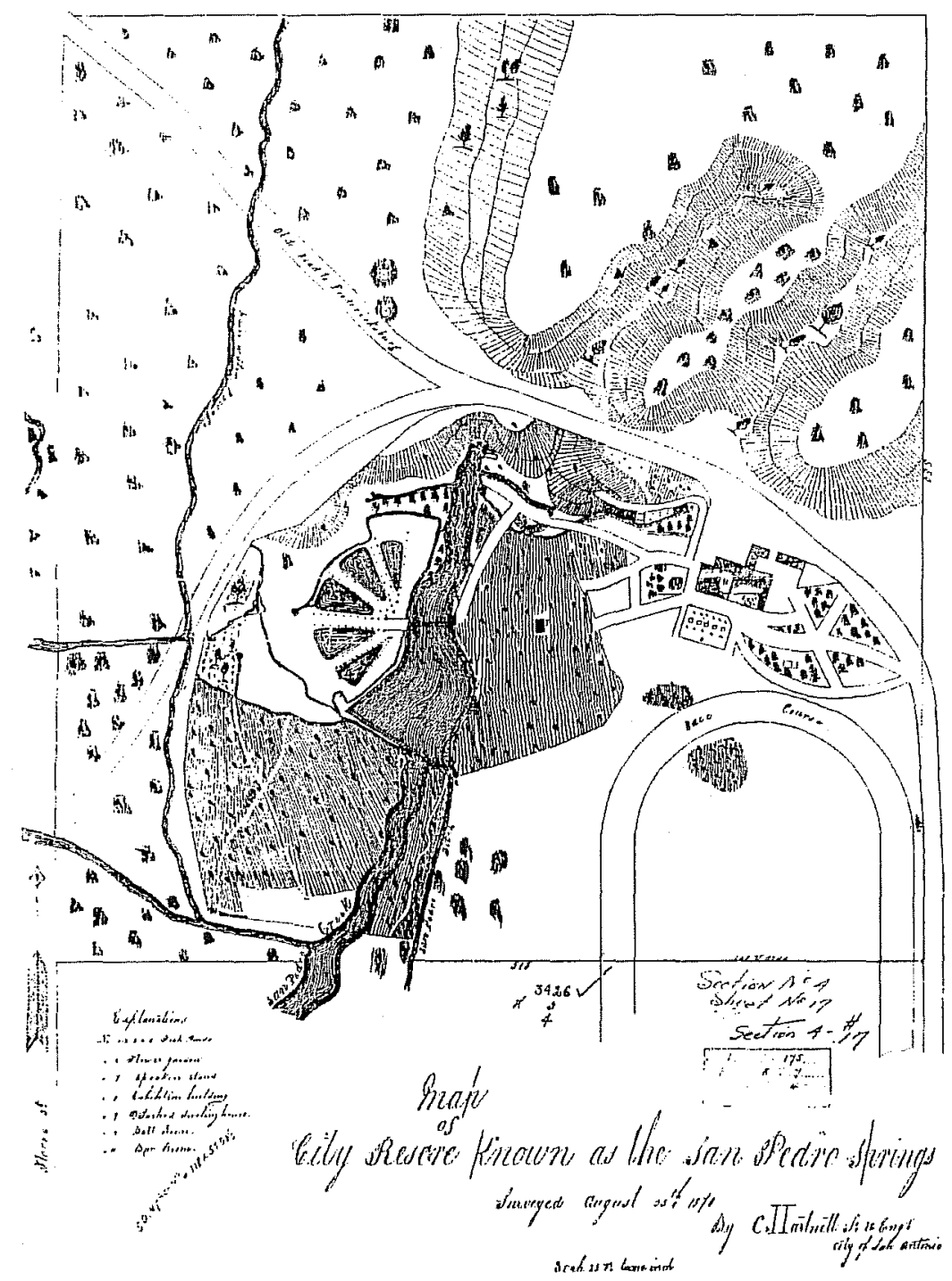


endeavor. The issue arose again in 1872, when engineer C. Hartnett proposed to construct the diversion to the west, but this time including a plan to irrigate the lands west of San Pedro Creek (CCM, D:63-71). This was probably intended to provide the additional incentive of increasing land values to offset construction costs. Before any action was taken, Hartnett was replaced by G. Friesleben, who deemed the former's plan unworkable (CCM, D:111). Friesleben's revised plan for the ditch was approved by city council in May 1874 , and construction began within four months.

Beginning at the confluence of Olmos Creek and the San Antonio River, the Alazán Acequia conveyed water through much of the old Upper Labor Acequia until it reached a point on San Pedro Avenue that had once served as a gate for the old acequia of the Labor Alta de Santa María. It then followed the old channel to the springs. Here a new channel was constructed to pass over the headwater of the springs to the right-ofway for the railroad and then south to the Alazán creek. The Alazán Acequia opened on June 9, 1875.

Problems with the ditch began almost immediately after its completion (CCM, Volume D:214), with evidence of poor construction and inadequate design ( $S A E, 17$ April 1875, 5 May 1875). Apparently, these problems were primarily concerned with the necessity of raising the wall of the original Upper Labor portion of the new ditch to accommodate the additional flow from the waters of Olmos Creek.

In December 1876, the new city engineer, Louis Giraud, presented city council with yet another plan to correct the persistent design problems. The ditch was cut deeper near Fredericksburg Road, but this additional work did not seem to help the situation. In 1894 the citizens near the park petitioned the city council to declare it a public nuisance and have it filled. This was approved, and in May 1895, the city purchased 620 loads of dirt and had the ditch filled from where it departed the Upper Labor (CCM L: January 15, 1874, May 27, 1895).

In the mid-1880s the city authorized funds for further improvement in the park. Among these improvements was the construction of a "summer house" over one of the springs in the southeast portion of the park ( $S A L$, 5 May 1885). In 1891 the last overall concession ended and the city took control of all city parks. The city made several improvements at this time including the installation of electric lights and the baseball park in the southeast corner which replaced the racetrack. Several limited concessions were allowed under city contract, including the rental of small row boats for the lake. Between 1897 and 1899, the new administration made several major improvements to the park. Driveways were constructed, the fan-shaped pools were filled, and the lake was lined with masonry. The zoo was moved to the western portion of the park, and the summer house was replaced with a conical rock with a fountainhead which watered ferns in the rock cavities (SAE, 17 March 1900).

\section{The Park in the Twentieth Century}

In the earliest portion of the century, San Pedro Park continued to be a popular place to spend a summer Sunday (Figure 10). In 1915, the zoo was relocated to Brackenridge Park, and work was undertaken to address the problem of flooding associated with the homes located near the park. The Sewer Construction Department began the excavation of a half-mile long channel constructed parallel to San Pedro Place (now Ashby Avenue) to the western margin of the park and draining to the south. The $30-\mathrm{ft}$ wide canal was five feet deep and its sloping sides were planted with grass. Pedestrian bridges were also constructed across the canal. At this same time, a 36-inch concrete sewer pipe was installed to facilitate drainage into San Pedro Creek (SAL, 17 January 1915).

In 1922, under Commissioner Ray Lambert, a municipal swimming pool was constructed by cementing the original lake bed, with the bridge that spanned the lake retained across the pool (Allen 1993). At this time the flow of the spring was still sufficient to exchange the water three times daily (Crook 1967:78-80). The first branch library building was constructed in 1929, facing San Pedro Avenue. The San Antonio Little Theater (SALT) was begun the same year. The architect, Bartlett Cocke, replicated the Fries and Rossi Market house facade for the east face, using templates created by pressing sheets of lead onto the original, which was then stored in a city warehouse (San Antonio Express-News [SAE-N], 21 September 1986). 


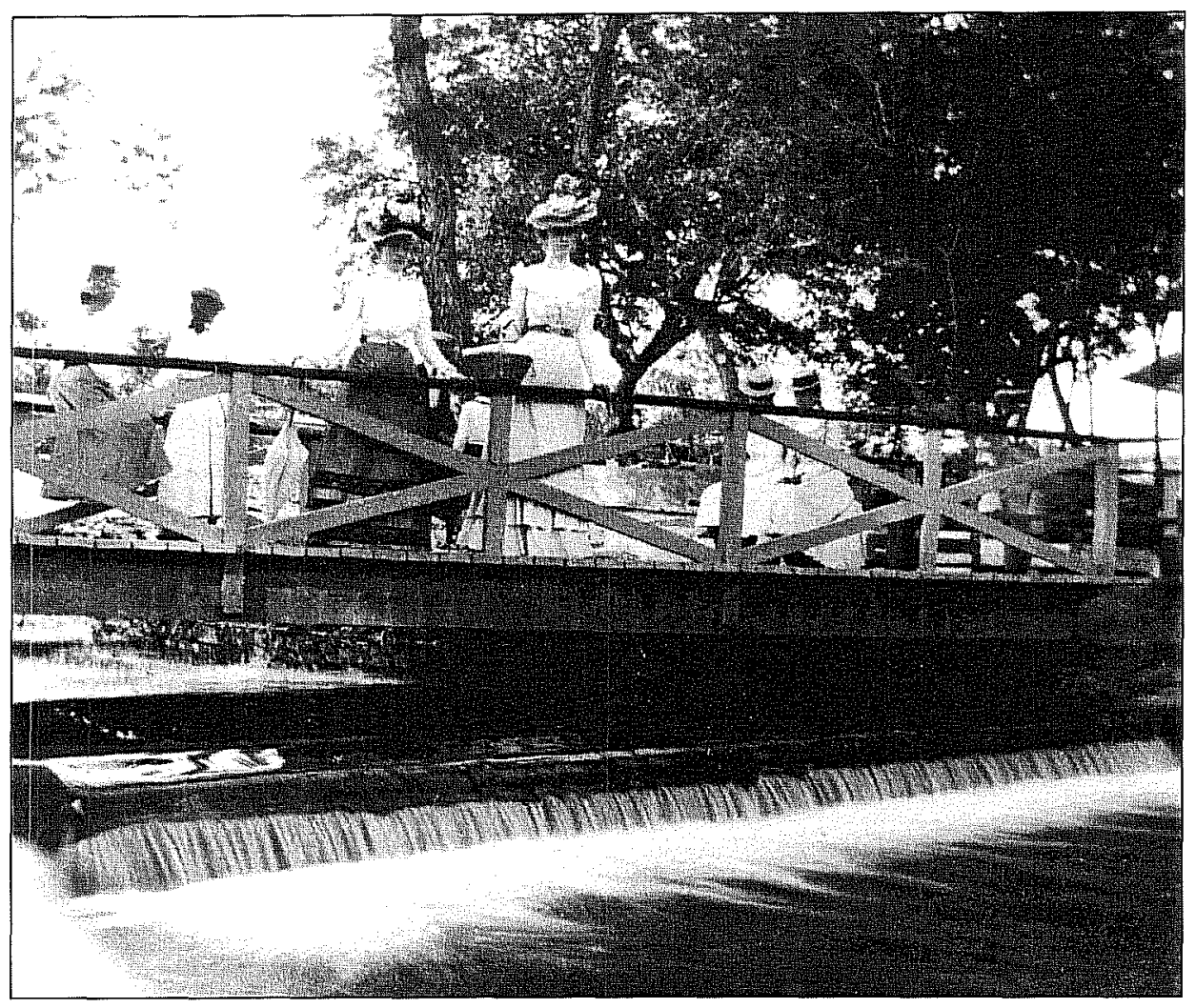

Figure 10. San Pedro Park in the early 1900s.

(Photograph in the collection of the Institute of Texan Cultures, San Antonio, Texas. Used with permission.)

The original swimming pool was closed in 1940 since the flow of the springs had diminished and was no longer sufficient to provide adequate clean water. A new, smaller pool was opened in 1954 with its water supply entirely dependent upon city water resources. The McFarlin Tennis Courts were opened the same year in the cavity of the old rock quarry (Crook 1967:95). In 1998-1999 the swimming pool was closed, and a new pool, shaped like the original pool (see Figure 9) was constructed. In addition, the park- ing lots in the southern part of the park were removed, the drainage ditches in the western part of the park were filled, and a new entrance along West Ashby Place was constructed.

San Pedro Park continues to be a popular place in San Antonio. The tennis courts, the theater, the library, the baseball diamonds, and the pool, as well as the open lawns, playgrounds, and large shade trees all serve as attractions. 


\section{Chapter 3: The 1996 Investigations}

\section{Barbara A. Meissner}

\section{Introduction}

The purpose of the 1996 project was:

(1) To determine the exact course of the Alazán acequia in order to pinpoint the location at which the SARA drainage project would cut through it as construction extended northward up North Flores Street; and

(2) To assess the likelihood that the construction would seriously impact other significant cultural resources.

The city of San Antonio Department of Parks and Recreation (DPR) granted CAR permission to complete three backhoe trenches (BHT) and a series of shovel tests (ST) in San Pedro Park adjacent to North Flores Street. This allowed CAR to make the assessments needed for the SARA project, and at the same time provide the DPR with a preliminary estimate of the nature and importance of any historic or prehistoric cultural resources along the western edge of the park itself. This also facilitated planning for other improvements in the park (S. Stover, personal communication 1997), as there was little information available concerning the extent to which urban development has disturbed cultural resources in the park.

\section{Methods}

\section{Backhoe Trenches}

Using a contour map of the park drawn by City Engineer G. E. Truehart, dated July 23, 1899, showing the course of the Alazán Acequia as it approaches North Flores Street, BHT A was placed at the northern end of the park (Figure 11) in an attempt to find the remains of the old ditch. Although the acequia had been

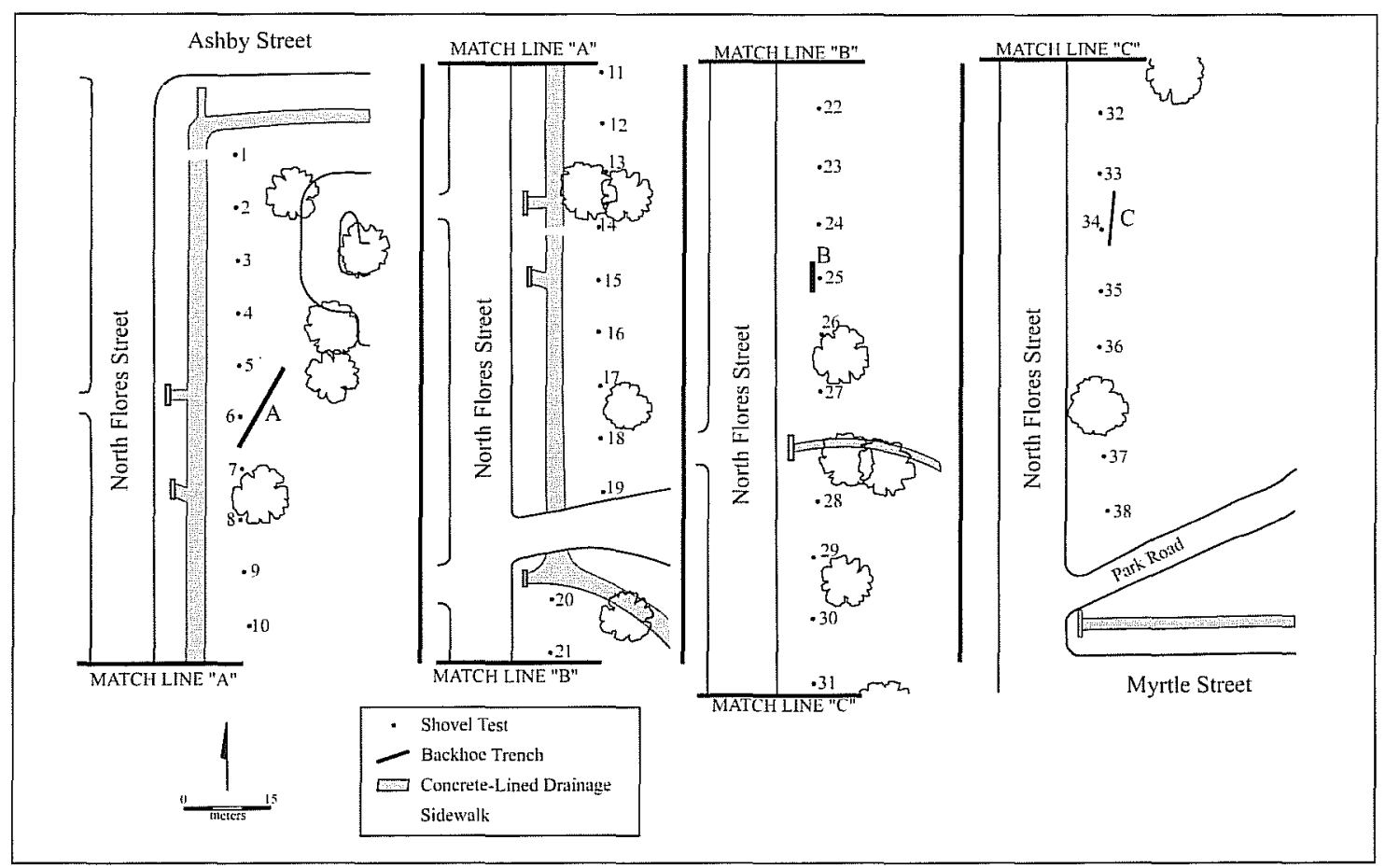

Figure 11. Map of the west side of San Pedro Park, showing location of shovel tests and backhoe trenches. 
Figure 12. Northwest corner of park in 1899, showing the estimated course of the Alazán acequia, based on the Truehart map.

Contour lines are every four feet.

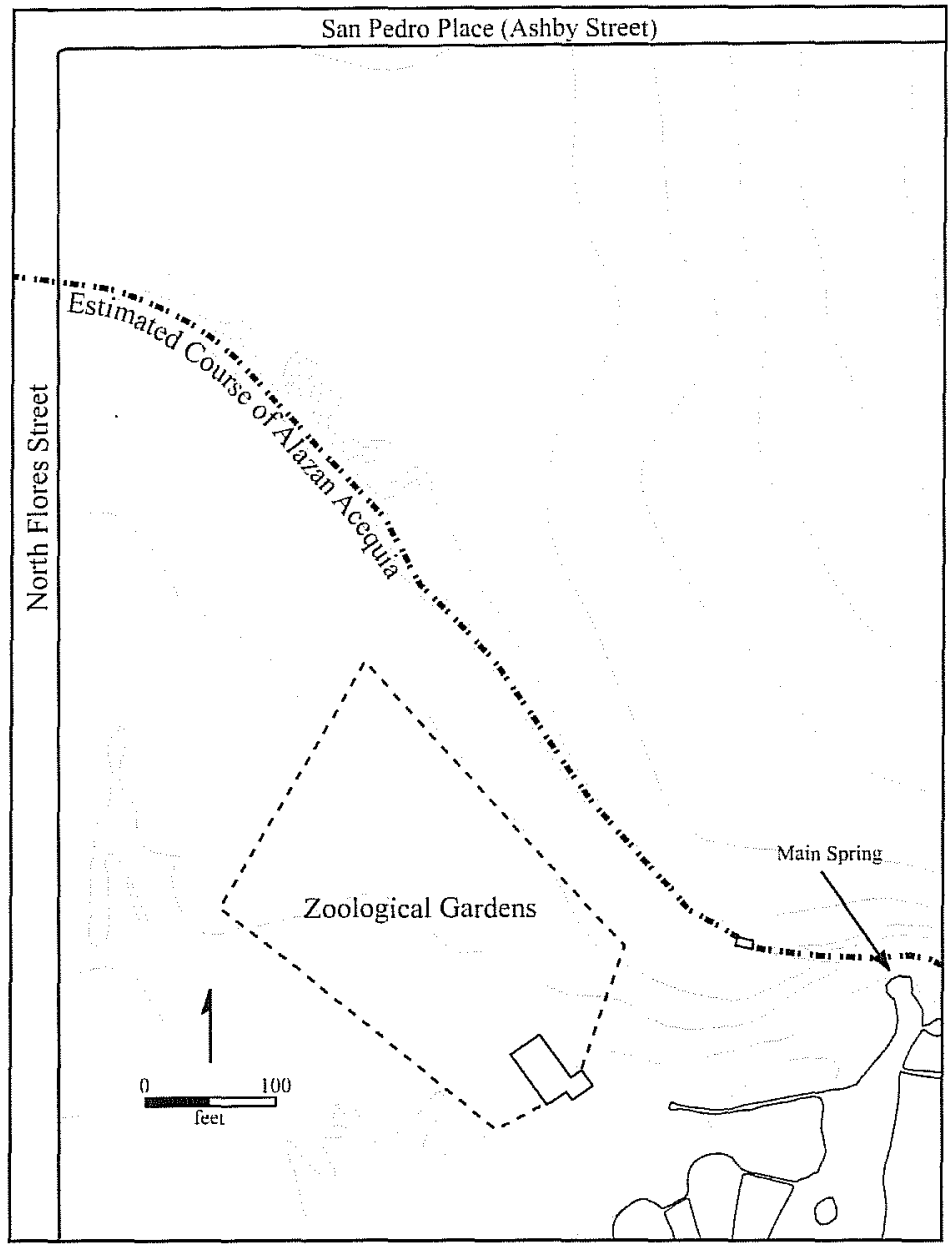

filled in some four years before Truehart's map was drawn, the fill had apparently subsided considerably, and the course of the acequia is still plainly visible in the map's contours (Figure 12). The trench, approximately $10 \mathrm{~m}$ long, was excavated to $280 \mathrm{~cm}$ below the ground surface and a detailed description of the soils and sediments was recorded.

BHTs B and C were placed so that the geomorphology of the western side of the park could be examined (Figure 11). BHT B was placed just south of the center of the park, near ST 25 (Figure 11). The trench was approximately $7 \mathrm{~m}$ long and $140 \mathrm{~cm}$ deep. BHT $\mathrm{C}$ was excavated near the southern end of the park, near STs 33 and 34 (Figure 11). It was approximately $10 \mathrm{~m}$ long and $130 \mathrm{~cm}$ deep. All artifacts observed during the trenching operation were collected and bagged, and notes were taken concerning the approximate provenience of the artifacts. Each BHT was filled as soon as all notes were completed.

\section{Shovel Tests}

The shovel tests were normally spaced at $10 \mathrm{~m}$ intervals along the entire length of the west side of the park, beginning at the northern end, $5 \mathrm{~m}$ east of the drainage ditch in the northern part of the project area, and $5 \mathrm{~m}$ east of the sidewalk in the southern part (Figure 11); otherwise spacing of shovel tests depended 
on the presence of sidewalks, drainage ditches, or trees. All tests were approximately $30 \mathrm{~cm}$ in diameter and were dug to a level of $70 \mathrm{~cm}$ below the ground surface, or to an impenetrable, compact gravel matrix. All sediments were screened through 3-inch wire mesh. Artifacts were collected and bagged by $10 \mathrm{~cm}$ level. Notes were taken concerning soils and sediments composition, and artifacts recovered (Figure 13). A smear of dampened soil from each level was placed on the shovel test form in order to provide a uniform setting for later soil color identification. After all smears had dried thoroughly, the soil color was identified using a Munsell chart.

\section{Laboratory}

All artifacts were washed, sorted, and cataloged. The historic artifacts were sorted into five major categories: Kitchen/Household items, Clothing/Personal items, Arms, Construction materials, and Miscellaneous. The prehistoric artifacts consisted of chipped stone. Each artifact category was examined separately, and notes were taken concerning identification, dating, and other information.

\section{Shovel Test and Backhoe Trench Results}

\section{Shovel Tests}

Thirty-five of 38 shovel tests $(92.1 \%)$ contained cultural material (see Table 2). Prehistoric artifacts comprised 65.5 percent $(n=711)$, and Historic artifacts made up 34.5 percent $(n=374)$ of the 1,085 artifacts recovered from the 35 tests. Additionally, 71 pieces of animal bone were recovered (see Appendices A and B). The only ST to reach the underlying bedrock was $\mathrm{ST} 1$, at $70 \mathrm{~cm}$.

\section{Disturbance}

At least some degree of disturbance caused by previous construction in the park was evident in STs 3,6 , 15-17, 19, 36-38, and possibly 31 . ST3 had two PVC pipes in it, one broken and one intact, about $15 \mathrm{~cm}$ below ground surface. A series of color changes in ST6 represents different episodes of construction fill. Later this test was shown to be directly over the acequia (see Figure 11). In STs 15 and 16, a caliche

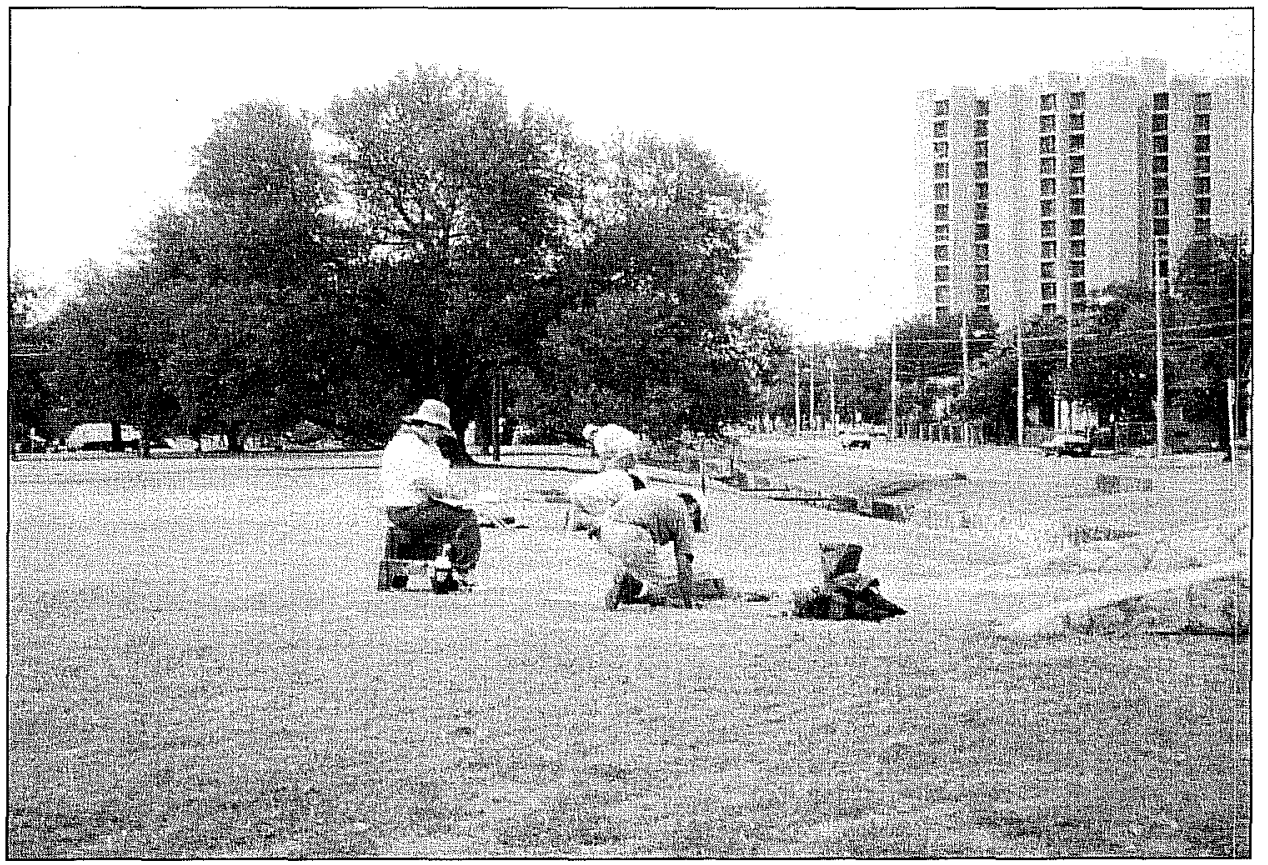

Figure 13. CAR personnel working on Shovel tests 1, 2, and 3, in the northwest corner of the park. Looking south. 
Table 2. Artifacts Recovered in Shovel Tests

\begin{tabular}{|c|c|c|c|c|c|}
\hline $\begin{array}{c}\text { ST \# } \\
\text { (Total \# of } \\
\text { Levels) }\end{array}$ & Level & & Artifacts & & Comments \\
\hline & & Historic & Prehist. & Faunal & \\
\hline ST $1(7)$ & 1 & 2 & & & \\
\hline & 2 & 2 & 1 & & \\
\hline ST 2(7) & 1 & 2 & 1 & & \\
\hline & 5 & & & 1 & \\
\hline ST 3 (5) & 1 & 3 & & & \\
\hline & 2 & 4 & 3 & & \\
\hline & 3 & 1 & 4 & & 4 in. PVC pipe intruding from west wall at approx. $30 \mathrm{~cm}$ BS \\
\hline & 4 & & 1 & & \\
\hline & 5 & & & & Excavation terminated due to interference from PVC pipe \\
\hline ST $4(7)$ & 1 & 15 & 1 & & \\
\hline & 2 & 19 & 1 & 1 & \\
\hline & 3 & 11 & 3 & & \\
\hline ST 5(7) & 1 & 15 & & & \\
\hline & 6 & 6 & - & & \\
\hline ST $6(7)$ & 2 & 1 & & & \\
\hline & 6 & 2 & 1 & & \\
\hline ST 7(7) & 1 & 9 & - & & \\
\hline & 2 & 1 & & & \\
\hline & 4 & & 1 & & \\
\hline & 6 & & 1 & & \\
\hline ST $8(7)$ & 1 & 6 & 1 & & \\
\hline & 2 & 4 & & & \\
\hline & 3 & 1 & & & \\
\hline & 5 & & 3 & 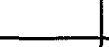 & \\
\hline & 6 & & 1 & & \\
\hline ST 9 (7) & 1 & 10 & 1 & 1 & \\
\hline & 2 & 6 & & 1 & \\
\hline & 3 & 2 & & & \\
\hline & 4 & & 2 & & \\
\hline & 5 & 2 & & & \\
\hline ST $10(7)$ & 1 & 14 & & & \\
\hline & 2 & 8 & & 1 & \\
\hline & 3 & 6 & 1 & & \\
\hline & 4 & & 1 & & \\
\hline & 5 & & 1 & & \\
\hline ST $11(7)$ & 1 & 8 & - & & \\
\hline & 2 & 1 & 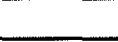 & & \\
\hline & 3 & 2 & & & \\
\hline & 5 & & 1 & & \\
\hline & 6 & 1 & 2 & & \\
\hline & 7 & & 1 & & \\
\hline ST $12(7)$ & 1 & 6 & 1 & & \\
\hline & 2 & 2 & & & \\
\hline & 5 & & 1 & & \\
\hline ST $13(7)$ & 1 & 3 & 1 & & \\
\hline & 2 & 1 & 2 & & \\
\hline & 5 & & 1 & & \\
\hline
\end{tabular}


Table 2. Artifacts recovered in Shovel Tests continued...

\begin{tabular}{|c|c|c|c|c|c|}
\hline $\begin{array}{c}\text { ST \# } \\
\text { (Total \# of } \\
\text { Levels) } \\
\end{array}$ & Level & \multicolumn{3}{|c|}{ Artifacts } & \multirow[t]{2}{*}{ Comments } \\
\hline & & Historic & Prehist. & Faunal & \\
\hline \multirow[t]{3}{*}{ ST $14(7)$} & 1 & 7 & & & \\
\hline & 2 & 8 & & & \\
\hline & 3 & & 2 & & \\
\hline \multirow[t]{2}{*}{ ST $15(2)$} & 1 & 4 & & & \\
\hline & 2 & & & & Excavation terminated - constuction Fill \\
\hline \multirow[t]{2}{*}{ ST $16(3)$} & 2 & 2 & & & \\
\hline & 3 & & & & Excavation terminated-construction fill \\
\hline \multirow[t]{3}{*}{ ST 17(7) } & 1 & . & 1 & & \\
\hline & 2 & 1 & & & \\
\hline & 4 & & 1 & & \\
\hline \multirow[t]{5}{*}{ ST $18(7)$} & 1 & 6 & & & \\
\hline & 3 & 12 & & & \\
\hline & 4 & 6 & 5 & 25 & \\
\hline & 6 & 6 & 2 & 3 & \\
\hline & 7 & & 1 & 1 & \\
\hline \multirow[t]{3}{*}{ ST $19(4)$} & 1 & 3 & & & \\
\hline & 2 & 9 & & & \\
\hline & 4 & & & & Excavation terminated-construction fill \\
\hline \multirow[t]{5}{*}{$\mathrm{ST} 20(7)$} & 1 & 22 & & & \\
\hline & 2 & 3 & 3 & & \\
\hline & 3 & 1 & 1. & & \\
\hline & 4 & & 6 & & \\
\hline & 7 & & 2 & & \\
\hline \multirow[t]{2}{*}{ ST $21(7)$} & 1 & 3 & & & \\
\hline & 2 & 3 & & & \\
\hline ST $22(7)$ & \multicolumn{4}{|c|}{ no cultural material } & \\
\hline \multirow[t]{4}{*}{ ST 23(7) } & 1 & 4 & 1 & & \\
\hline & 5 & & 6 & & \\
\hline & 6 & 8 & 4 & 4 & \\
\hline & 7 & & 1 & & \\
\hline \multirow[t]{6}{*}{ ST $24(7)$} & 2 & 1 & 6 & & \\
\hline & 3 & & 4 & & \\
\hline & 4 & 1 & 4 & 3 & \\
\hline & 5 & & 7 & & \\
\hline & 6 & & 14 & & \\
\hline & 7 & & 8 & & \\
\hline \multirow[t]{6}{*}{ ST 25 (7) } & 1 & 7 & & & \\
\hline & 2 & 6 & & & \\
\hline & 3 & 1 & 3 & & \\
\hline & 5 & & 2 & 1 & \\
\hline & 6 & & 1 & 1 & \\
\hline & 7 & & 6 & & \\
\hline \multirow[t]{6}{*}{ ST 26(7) } & 1 & 2 & 2 & & \\
\hline & 2 & 1 & 3 & & \\
\hline & 3 & & 3 & & \\
\hline & 4 & & 1 & & \\
\hline & 5 & & 1 & & \\
\hline & 6 & & 2 & & \\
\hline
\end{tabular}


Table 2. Artifacts recovered in Shovel Tests continued...

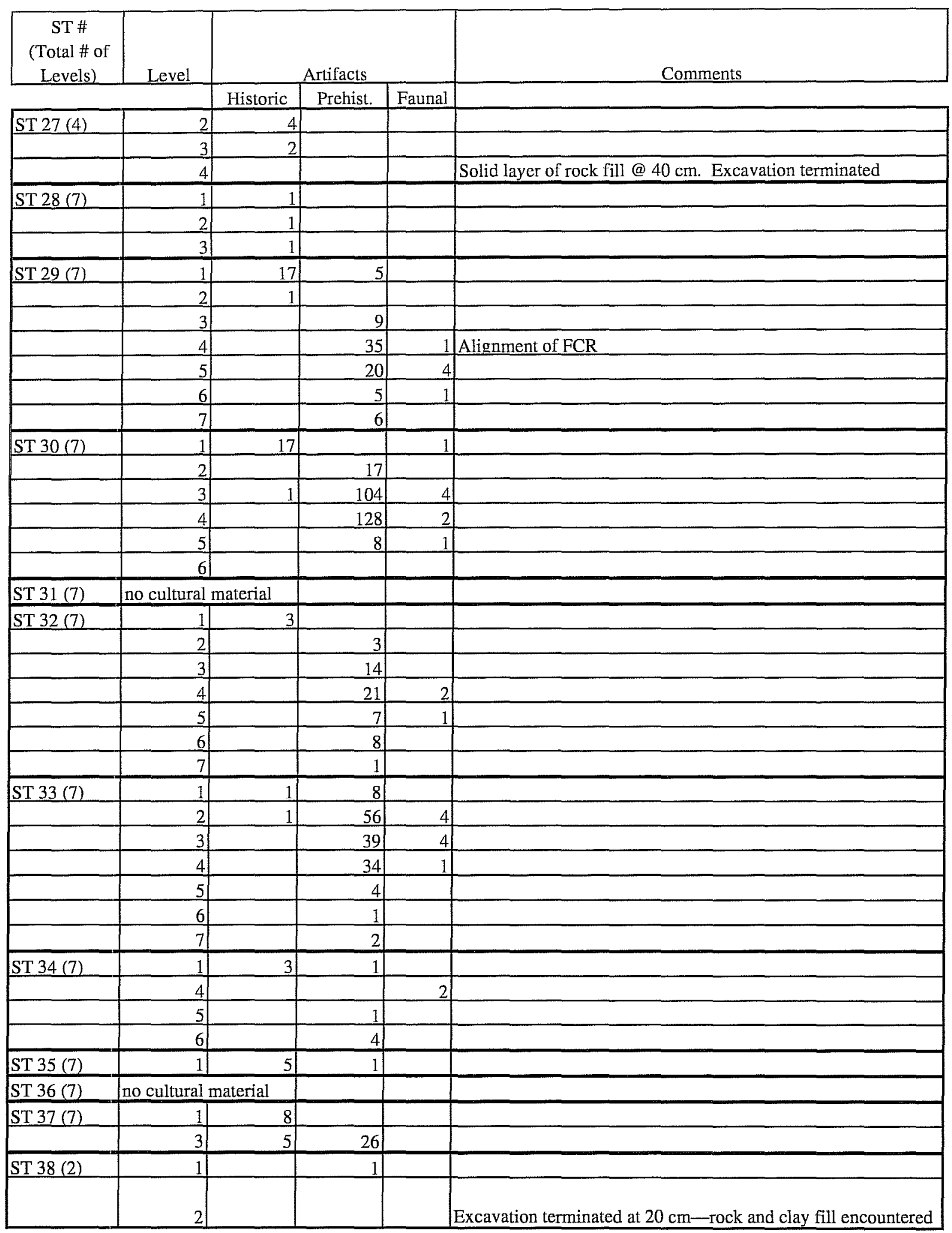


and gravel mixture was encountered at about $10 \mathrm{~cm}$ below the ground surface. ST17 had a layer of caliche fill over several layers of silty clay fill. In the lowest two levels the sediment was extremely soft. ST19 was terminated at $35 \mathrm{~cm}$ because cemented limestone rubble was encountered. ST 36 contained $35 \mathrm{~cm}$ of sand fill over a layer of clay loam. There were no artifacts in this test. ST37 had a $10 \mathrm{~cm}$ layer of clay mixed with caliche over a layer of solid caliche fill. Below this was a layer of clay loam. The area around ST38 was obviously disturbed, and when a packed caliche and rock fill was encountered at about $20 \mathrm{~cm}$ below the ground surface, the test was terminated.

\section{Artifacts}

Although STs 22, 31, and 36 yielded no artifacts, the quantity of prehistoric artifacts per shovel test generally increased as the tests continued south. Exceptions were ST27, which was terminated at $40 \mathrm{~cm}$ below ground surface due to a layer of large rocks believed to be construction fill, and ST28, which contained no prehistoric artifacts and only 3 historic artifacts in the upper levels. The relative quantity of prehistoric artifacts recovered increased significantly in ST 29; a total of 72 chert flakes and 8 pieces of fire-cracked limestone were found. A possible small hearth feature with fire-cracked rock was recorded at about $40 \mathrm{~cm}$. Thirty-five flakes were recovered in the same level (Level 4). The largest quantity of prehistoric artifacts was recovered from ST30 $(n=257), 90.3$ percent of which $(n=232)$ were encountered in Levels 3 and 4 (between 20 and $40 \mathrm{~cm}$ below ground surface.) Artifacts included a biface fragment, a uniface fragment, a utilized flake, and six pieces of ocher which mended to form one large piece, probably broken by the shovel. Beginning with ST30 and extending to ST34, the sediments were much softer and easier to dig. ST32 also contained a large number of prehistoric artifacts; a total of 56. Artifacts included a multifaceted polyhedral core and a piece of ocher. ST33 contained 139 prehistoric artifacts, including the base of what appears to be a Scallorn preform, a core and a uniface. With ST34, the quantity of prehistoric artifacts per shovel test decreased to a level consistent with the tests north of ST 29. Four prehistoric artifacts were recovered from ST34, and only one was recovered from ST35. Although there were 19 prehistoric artifacts in ST 37, including one biface fragment which appeared to be the distal tip of arrow point, as discussed in the preceding section, it appears they were transported in with the caliche fill.

ST4 had 39 historic artifacts, the highest quantity in any of the tests. Although STs to the north and south of ST 18 were disturbed, this test did not appear to be disturbed. Eight prehistoric artifacts, 29 pieces of bone, and 28 historic artifacts including unglazed earthenwares, lead-glazed and tin-glazed wares, and whitewares were found in ST18.

\section{Backhoe Trenches}

Three profile descriptions are presented (Tables $3-$ 5). Profile A has a $150+\mathrm{cm}$-thick profile with an ABt-Bk1-Bk2-Bk3 soil horizon sequence. These sediments represent a colluvial accumulation of deposits that have been altered by pedogenic processes. Figure 14 shows that the Alazán acequia was excavated through a caliche zone ( $\mathrm{Bk} 2$ and $\mathrm{Bk} 3$ horizons)

Table 3. Profile Descriptions of BHT A

\begin{tabular}{|c|c|c|c|}
\hline Zone & $\begin{array}{l}\text { Depth } \\
\text { bgs } \\
(\mathrm{cm})\end{array}$ & $\begin{array}{l}\text { Munsell } \\
\text { Color }\end{array}$ & $\begin{array}{c}\text { Description } \\
\text { (from southern end of trench) }\end{array}$ \\
\hline 1 & $0-36$ & $10 Y R 3 / 2$ & $\begin{array}{l}\text { Very dark gravish brown silt loam. Medium moderate } \\
\text { subangular blocky. Common } \mathrm{CaCO}_{7} \text { nodules and flecks. } \\
\text { Common snail shell, common roots, common rootlets, chert } \\
\text { core at } 30 \mathrm{~cm} \text {. Smooth clear lower boundary. }\end{array}$ \\
\hline 2 & $36-57$ & $10 \mathrm{YR} 3 / 1$ & $\begin{array}{l}\text { Very dark gray clay loam. Fine/medium moderate } \\
\text { subangular blocky. Rare } \mathrm{CaCO}_{7} \text { filaments that increase } \\
\text { down profile. Few snails shell, few rootlets, common worm } \\
\text { casts. Clear smooth lower boundary. Buried A horizon. }\end{array}$ \\
\hline 3 & $57-90$ & $10 \mathrm{YR} 3 / 2$ & $\begin{array}{l}\text { Very dark grayish brown silt loam. Moderate/medium } \\
\text { subangular blocky. Twenty percent } \mathrm{CaCO}_{3} \text { filaments on ped } \\
\text { faces. Common rootlets, chert flake at } 75 \mathrm{~cm} \text {. Gradual } \\
\text { smooth lower boundary. }\end{array}$ \\
\hline 4 & $90-140$ & $10 \mathrm{YR} 5 / 2$ & $\begin{array}{l}\text { Gray brown silt loam. } 25-30 \text { percent soft, small }(10 \mathrm{~mm}) \\
\text { carbonate nodules, increasing down profile. Rare rootlets, } \\
\text { rare infilled insect burrows, rare snail shells. Gradual } \\
\text { smooth lower boundary. }\end{array}$ \\
\hline 5 & $140-150$ & $\begin{array}{l}10 Y R 7 / 2 \\
\text { to } \\
10 Y R 7 / 4\end{array}$ & $\begin{array}{l}\text { Light gray to very pale brown } \mathrm{CaCO}_{3} \text {. Lower boundary at } \\
\text { bedrock. }\end{array}$ \\
\hline
\end{tabular}


Table 4. Profile Descriptions of BHT B

\begin{tabular}{|c|c|c|c|}
\hline Zone & $\begin{array}{c}\text { Depth } \\
\text { bgs } \\
\text { (cm) }\end{array}$ & $\begin{array}{c}\text { Munsell } \\
\text { Color }\end{array}$ & \multicolumn{1}{|c|}{ Description } \\
\hline 1 & $0-10$ & 10 YR4/2 & $\begin{array}{l}\text { Dark grayish brown loam. Common rootlets. } \\
\text { Abrupt irregular lower boundary. Sandy fill. }\end{array}$ \\
\hline 2 & $10-30$ & $10 Y R 3 / 2$ & $\begin{array}{l}\text { Very dark grayish brown silt loam. Fine moderate } \\
\text { blocky Scattered CaCO nodules, especially } \\
\text { common in he lower 10cm of zone. Abrupt smooth } \\
\text { lower boundary. }\end{array}$ \\
\hline 3 & $30-55$ & $10 Y$ R3/1 & $\begin{array}{l}\text { Very dark gray clay loam. Fine Medium moderate } \\
\text { subangular blocky. Few rootlets, flakes and burned } \\
\text { rocks at 45 cm (A horizon). Gradual smooth lower } \\
\text { boundary. }\end{array}$ \\
\hline 4 & $55-75$ & $10 Y R 4 / 1$ & $\begin{array}{l}\text { Dark gray silt loam. Medium moderate subangular } \\
\text { blocky. Few (less than 5\%) CaCO nodules. Few } \\
\text { Snail shell. Gradual smooth lower boundary. }\end{array}$ \\
\hline 5 & $75-140$ & $2.5 Y R 5 / 2$ & $\begin{array}{l}\text { Gravish brown silt loam. Moderate medium } \\
\text { subangular blocky. Few ca. 15 \% CaCO nodules. } \\
\text { Few rootlets, rare roots. Lower boundary not } \\
\text { observed. }\end{array}$ \\
\hline
\end{tabular}

and into limestone bedrock. The upper bank of the acequia was not discernible in the very dark gray silt loam (A and Bt horizons). A section of concrete storm drain 36 inches in diameter was uncovered in the southern portion of BHT A, running perpendicular to the backhoe cut.

A similar profile was recorded in BHT B (Table 4). The major difference is the presence of a 10 -cm-thick dark grayish brown loam that represents a layer of fill
(Ap horizon). The A horizon is thinner in BHT B, but the accumulation of sediments appears to be the result of colluvial and spring processes. Prehistoric artifacts were observed at $45 \mathrm{~cm}$ in BHT B. BHT C also has similar sediments and soil horizons, although not as clayey (Table 5). A thin layer of fill was recorded in the upper three centimeters. Between 3 and $65 \mathrm{~cm}$ are two A horizons in a dark gray silt loam, and Prehistoric artifacts and bone were observed at 15, 35, and $45 \mathrm{~cm}$. Two Bk horizons are recorded between 75 to $130+\mathrm{cm}$ in the lower portion of the profile.

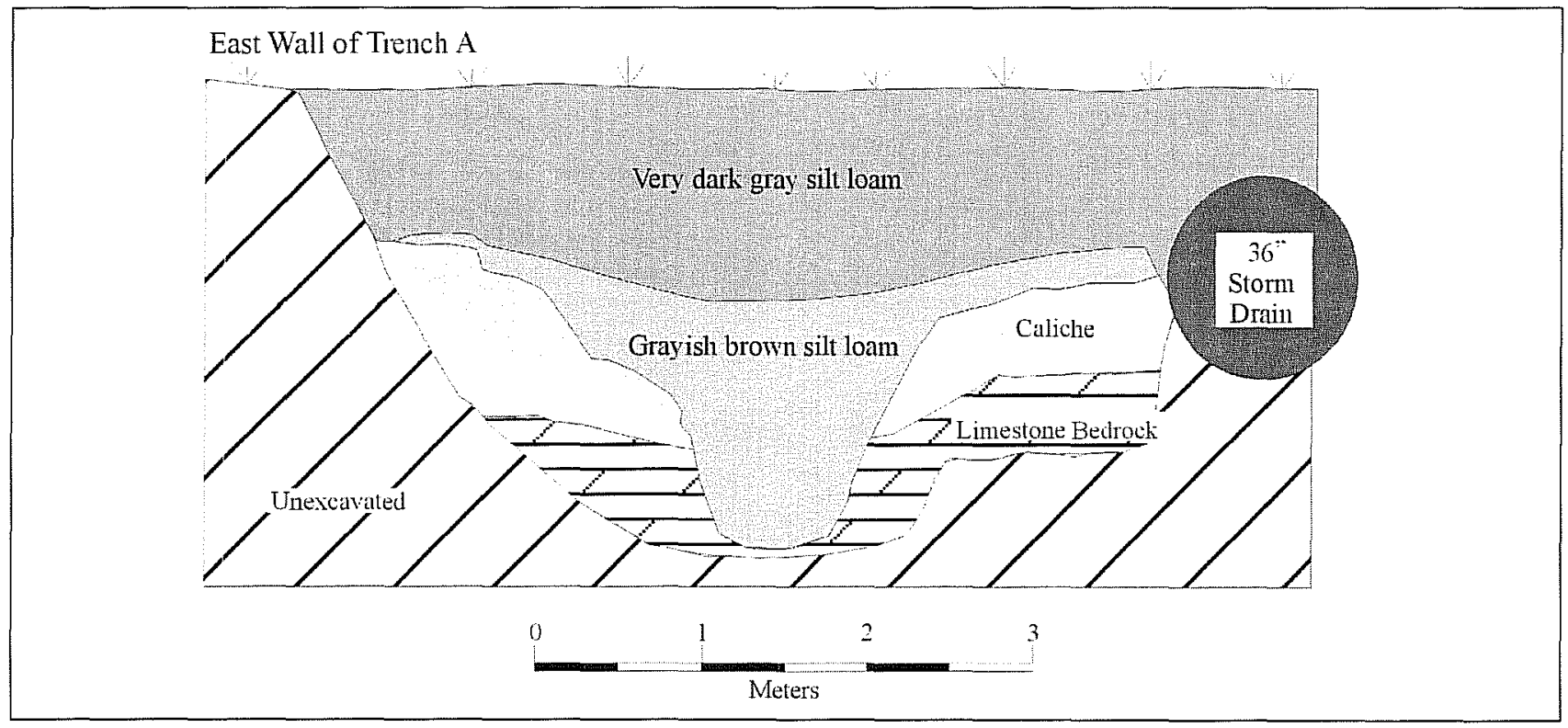

Figure 14. Profile of BHT A, showing the remains of the Alazán acequia. 
Table 5. Profile Descriptions of BHT C

\begin{tabular}{|c|c|c|c|}
\hline Zone & $\begin{array}{l}\text { Depth bgs } \\
\text { (cm) }\end{array}$ & $\begin{array}{c}\text { Munsell } \\
\text { Color }\end{array}$ & 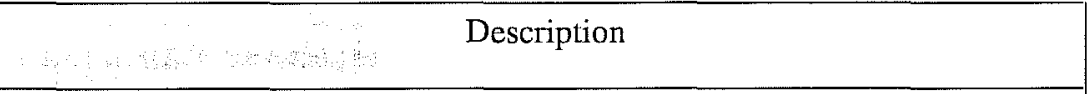 \\
\hline 1 & $0-3$ & $10 Y R 7 / 3$ & $\begin{array}{l}\text { Very pale brown loose fill of carbonate } \mathrm{CaCO}_{3} \text { nodules. Abrupt smooth } \\
\text { lower boundary. }\end{array}$ \\
\hline 2 & $3-50$ & 10YR3/1 & $\begin{array}{l}\text { Very dark gray silt loam. Medium to fine moderate subangular blocky. Rare } \\
\mathrm{CaCO}_{3} \text { filaments on ped faces that increase down profile. Flake at } 15 \mathrm{~cm} \text {, } \\
\text { bone at } 35 \mathrm{~cm} \text {, core fragment at } 45 \mathrm{~cm} \text {. Common snails at } 10 \text { to } 20 \mathrm{~cm} \text {. } \\
\text { Smooth gradual lower boundary. }\end{array}$ \\
\hline 3 & $50-65$ & $10 Y R 4 / 1$ & Dark gray silt loam. Same as above. Smooth gradual lower boundary. \\
\hline 4 & $65-75$ & $10 Y R 4 / 1$ & $\begin{array}{l}\text { Dark gray silt loam. Medium to fine moderate subangular blocky. Rare } \\
\mathrm{CaCO}_{3} \text { nodules. }\end{array}$ \\
\hline 5 & $75-130$ & $10 \mathrm{YR} 4 / 1$ & $\begin{array}{l}\text { Same as above except common (ca. } 30 \% \text { ), small (to } 15 \mathrm{~mm} \text { ) } \mathrm{CaCO}_{3} \text { nodules. } \\
\text { Lower boundary not observed. }\end{array}$ \\
\hline
\end{tabular}

No artifacts or faunal remains were collected from BHT A; 15 prehistoric and three historic artifacts were collected from BHT B; and 28 prehistoric and three historic artifacts were collected from BHT C (see Appendix A). No faunal remains were found in BHTs $A$ and $B$, but 22 pieces were collected from BHT $C$ (see Appendices A and B).

\section{Discussion}

The borehole data (see Figure 7) and the backhoe profile descriptions (Tables 3-5) indicate that sediments were deposited by colluvial processes from the area north of the park, and redeposited by the spring in the southern portion of the park. As discussed in Chapter 2, a moderate-sized pond existed below the springs in the mid-1800s, allowing colluvial-alluvial deposits to accumulate along its banks. At this point it is not clear if the pond and paludal deposits had been stationary throughout the Late Pleistocene and Holocene. However, the surface clays contain abundant archaeological materials and it appears that most have accumulated during the Late Pleistocene and Holocene.
The 38 shovel tests showed that there are some areas of the park in which construction and landscaping have disturbed the subsurface. These disturbances were especially evident in STs $3,6,15-17,19,27$, possibly 31 , and 36-38. However, evidence from the remaining 28 shovel tests indicate that discrete areas of intact deposits still exist within the park, primarily in its southern portion.

\section{Historic Component}

In spite of apparent disturbance in some areas, a plot of historic artifact densities in each shovel test indicates that the distribution generally decreases in quantity from north to south (Figure 15).

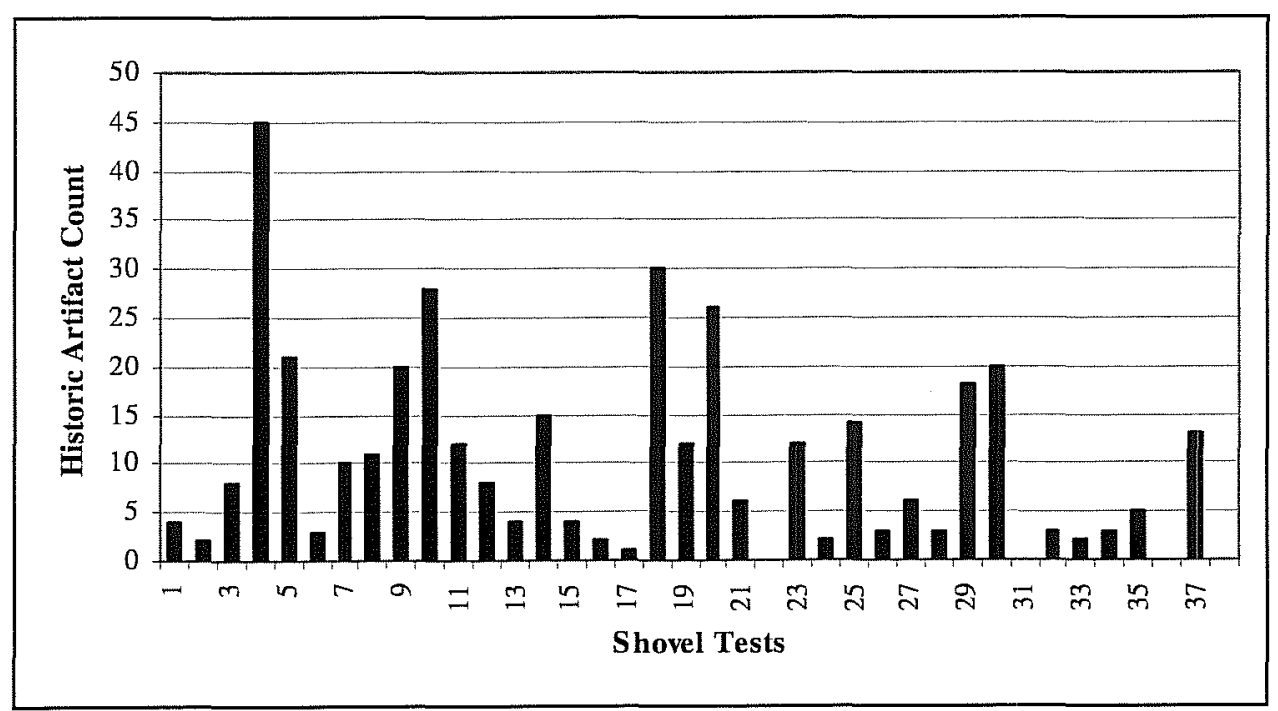

Figure 15. Historic artifact counts by shovel tests. 
Table 6. Historic Artifact Distribution

\begin{tabular}{|c|c|c|c|c|c|c|c|c|}
\hline & \multicolumn{7}{|c|}{ Level } & \\
\hline ST\# & 1 & 2 & 3 & 4 & 5 & 6 & 7 & Total \\
\hline 1 & 2 & 2 & & & & & & 4 \\
\hline 2 & 2 & & & & & & & 2 \\
\hline 3 & 3 & 4 & 1 & & & & & 8 \\
\hline 4 & 15 & 19 & 11 & & & & & 45 \\
\hline 5 & 15 & & & & & 6 & & 21 \\
\hline 6 & & 1 & & & & 2 & & 3 \\
\hline 7 & 9 & 1 & & & & & & 10 \\
\hline 8 & 6 & 4 & 1 & & & & & 11 \\
\hline 9 & 10 & 6 & 2 & & 2 & & & 20 \\
\hline 10 & 14 & 8 & 6 & & & & & 28 \\
\hline 11 & 8 & 1 & 2 & & 1 & & & 12 \\
\hline 12 & 6 & 2 & & & & & & 8 \\
\hline 13 & 3 & 1 & & & & & & 4 \\
\hline 14 & 7 & 8 & & & & & & 15 \\
\hline 15 & 4 & & & & & & & 4 \\
\hline 16 & & 2 & & & & & & 2 \\
\hline 17 & & 1 & & & & & & 1 \\
\hline 18 & 6 & 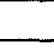 & 12 & 6 & & 6 & & 30 \\
\hline 19 & 3 & 9 & & & & & & 12 \\
\hline 20 & 22 & 3 & 1 & & & . & & 26 \\
\hline 21 & 3 & 3 & & & & . & & 6 \\
\hline 22 & & & & & & & & 0 \\
\hline 23 & 4 & & & & & 8 & & 12 \\
\hline 24 & 1 & & & 1 & & & & 2 \\
\hline 25 & 7 & 6 & 1 & & & & & 14 \\
\hline 26 & 2 & 1 & & & & & & 3 \\
\hline 27 & & 4 & 2 & & & & & 6 \\
\hline 28 & 1 & 1 & 1 & & & & & 3 \\
\hline 29 & 17 & 1 & & & & & & 18 \\
\hline 30 & 17 & & 3 & & & & & 20 \\
\hline 31 & & & & & & & & 0 \\
\hline 32 & 3 & & & & & & & 3 \\
\hline 33 & 1 & 1 & & & & & & 2 \\
\hline 34 & 3 & & & & & & & 3 \\
\hline 35 & 5 & & & & & & & 5 \\
\hline 36 & & & & & & & & 0 \\
\hline 37 & 8 & & 5 & & & & & 13 \\
\hline 38 & & & & & & & & 0 \\
\hline Total & 207 & 89 & 48 & 7 & 3 & 22 & 0 & 376 \\
\hline
\end{tabular}

An analysis of historic artifact distribution by level shows the greatest density of historic artifacts occurs from 0 to $10 \mathrm{~cm}$ below the surface (Level 1), and, as expected, quantities decrease with increased depth of excavation (see Table 6 and Figure 16). Figure 16 identifies distinct concentrations in Levels 1 and 2 between STs 1 through 17, Levels 1 through 3 in STs 17 through 22, and Level 5 in STs 25 through 38.
The obvious exceptions occur in STs 5, 6, 18, and 23. Although disturbed sediments were observed in STs 6 and 18, the artifacts recovered from 50 to $60 \mathrm{~cm}$ below the surface (Level 6) in STs 5 and 23 may represent areas of intact historic cultural deposits. 
Figure 16. Historic artifact counts by level.
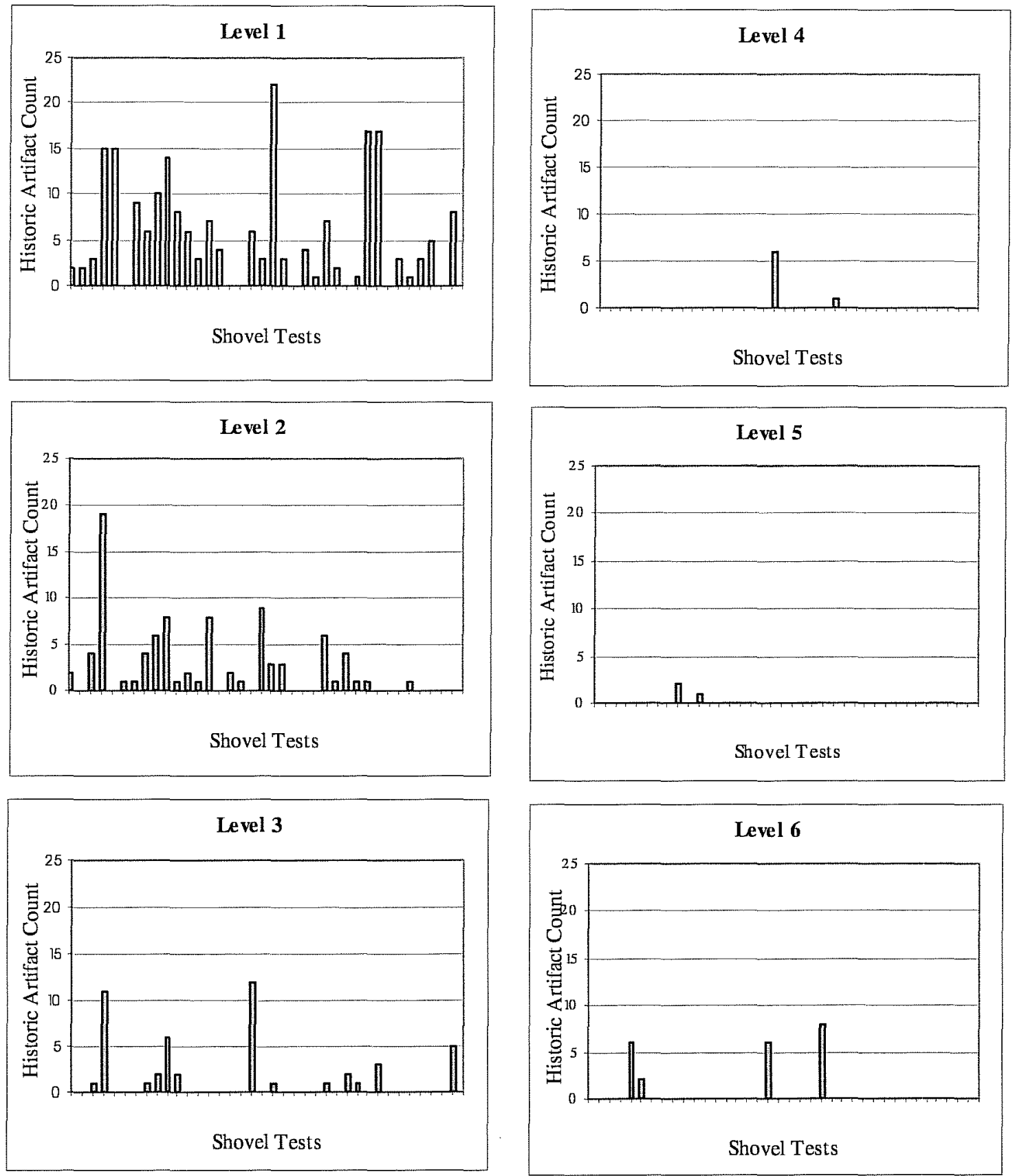


\section{Prehistoric Component}

An analysis of prehistoric artifact distribution along the western edge of the park from north to south reveals that, generally, the density of artifacts increases significantly on the southern end of the park (Figure 17), with the greatest density of prehistoric artifacts occurring from 20 to $40 \mathrm{~cm}$ below the surface in that area (Levels 3 and 4), between STs 29 and 34 (see Table 7 and Figure 18). As noted previously, the sediments and soils in STs 29 through 34 did not appear to be disturbed. This piece of evidence complements the archaeological data to suggest an intact prehistoric cultural deposit may be present in those levels, in the southwestern portion of the park. The relatively high densities of fire-cracked rock in Levels 3 and 4 of STs 29 and 30 provide further evidence of potentially intact cultural deposits.
Figure 17. Prehistoric artifact counts by shovel test.

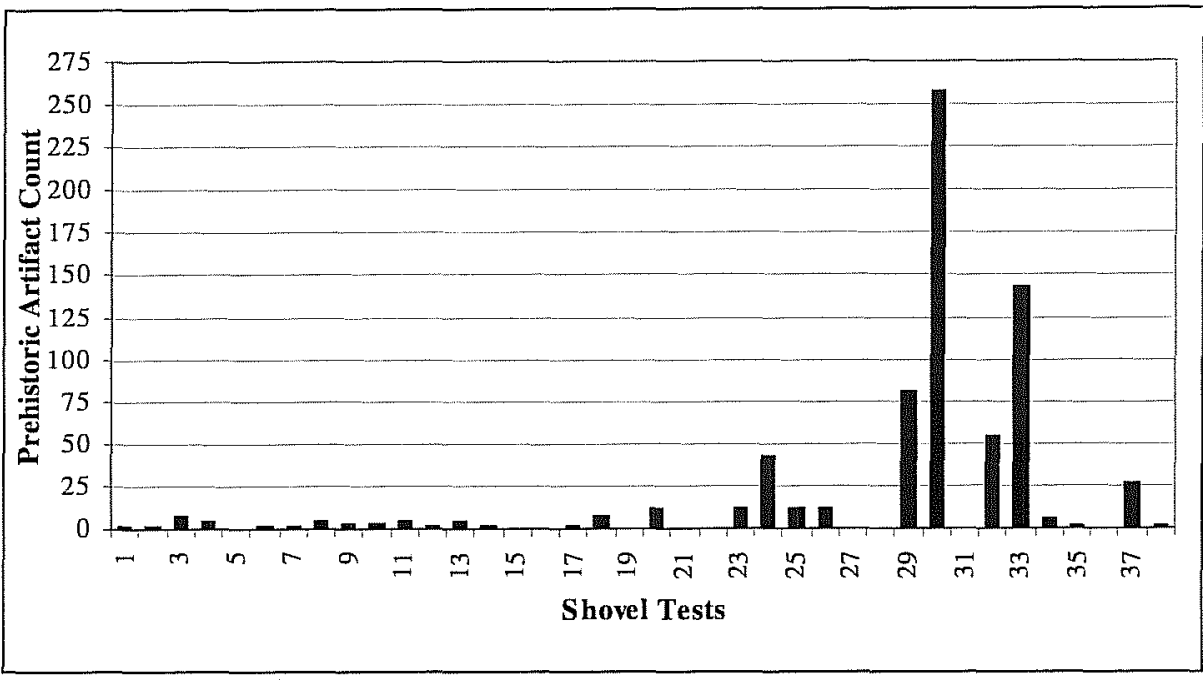

Table 7. Prehistoric Artifact distribution

\begin{tabular}{|c|c|c|c|c|c|c|c|c|}
\hline & \multicolumn{7}{|c|}{ Level } & \\
\hline ST\# & 1 & 2 & 3 & 4 & 5 & 6 & 7 & Total \\
\hline 1 & & 1 & & & & & & 1 \\
\hline 2 & 1 & & & & & & & 1 \\
\hline 3 & & 3 & 4 & 1 & & & & 8 \\
\hline 4 & 1 & 1 & 3 & & & & & 5 \\
\hline 5 & & & & & & & & 0 \\
\hline 6 & & & & & & 1 & & 1 \\
\hline 7 & & & & 1 & & 1 & & 2 \\
\hline 8 & 1 & & & & 3 & 1 & & 5 \\
\hline 9 & 1 & & & 2 & & & & 3 \\
\hline 10 & & & 1 & 1 & 1 & & & 3 \\
\hline 11 & & & & & 1 & 2 & 1 & 4 \\
\hline 12 & 1 & & & & 1 & & & 2 \\
\hline 13 & 1 & 2 & & & 1 & & & 4 \\
\hline 14 & & & 2 & & & & & 2 \\
\hline 15 & & & & & & & & 0 \\
\hline 16 & & & & & & & & 0 \\
\hline 17 & 1 & & & 1 & & & & 2 \\
\hline 18 & & & & 5 & & 2 & 1 & 8 \\
\hline 19 & & & & & & & & 0 \\
\hline 20 & & 3 & 1 & 6 & & & 2 & 12 \\
\hline 21 & & & & & & & & 0 \\
\hline 22 & & & & & & & & 0 \\
\hline 23 & 1 & & & & 6 & 4 & 1 & 12 \\
\hline 24 & & 6 & 4 & 4 & 7 & 14 & 8 & 43 \\
\hline 25 & & & 3 & & 2 & 1 & 6 & 12 \\
\hline 26 & 2 & 3 & 3 & 1 & 1 & 2 & & 12 \\
\hline 27 & & & & & & & & 0 \\
\hline 28 & & & & & & & & 0 \\
\hline 29 & 5 & & 9 & 35 & 20 & 5 & 6 & 80 \\
\hline 30 & & 17 & 104 & 128 & 8 & & & 257 \\
\hline 31 & & & & & & & & 0 \\
\hline 32 & & 3 & 14 & 21 & 7 & 8 & 1 & 54 \\
\hline 33 & 8 & 56 & 39 & 34 & 4 & 1 & 2 & 144 \\
\hline 34 & 1 & & & & 1 & 4 & & 6 \\
\hline 35 & 1 & & & & & & & 1 \\
\hline 36 & & & & & & & & 0 \\
\hline 37 & & & 26 & & & & & 26 \\
\hline 38 & 1 & & & & & & & 1 \\
\hline Total & 26 & 95 & 213 & 240 & 63 & 46 & 28 & 711 \\
\hline
\end{tabular}


Figure 18. Prehistoric artifact counts by level.
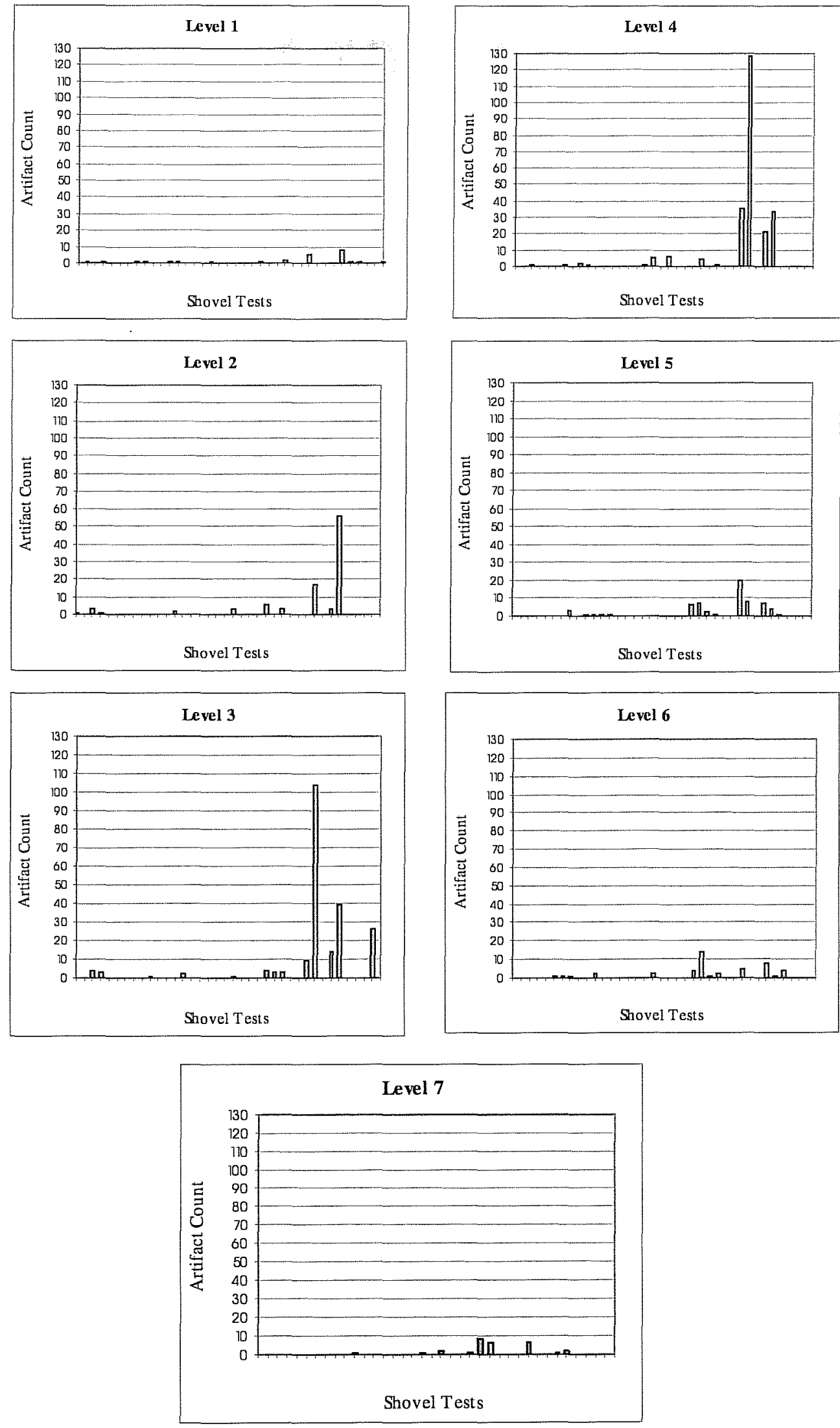


\section{Artifact Analysis}

The 38 STs and three BHTs yielded 1,106 artifacts, of which 726 (65.6 percent) were prehistoric and 380 (34.4 percent) were historic. In addition, 93 pieces of animal bone were recovered. A provenienced listing of the artifacts can be found in Appendix A. This section describes the artifacts and faunal material recovered from the STs and BHTs, as well as a small collection of artifacts found on the surface in the park over a period of several years and donated to CAR.

\section{Historic Artifacts}

The total of 380 historic artifacts is considered minimal, given the urban character of the park setting. However, San Pedro Park has been a city reserve during the entire historic period, and that has most likely limited the number and kind of artifacts left in the park. In fact, 63.2 percent $(n=240)$ of the historic artifacts are pieces of broken bottle and jar glass.

\section{Kitchen/Household Items}

A total of 267 items used in a kitchen and elsewhere in the household were recovered during the project, however 240 (89.9 percent ) were broken bottle and jar glass sherds. Excluding the glass, only 27 household items were recovered. This is not surprising, since, as far as we have been able to determine, no one in the historic period has permanently resided on the western edge of the park (although there possibly was military camping; see Chapter 2).

\section{Ceramics}

Twenty ceramic sherds were recovered. They are described briefly below. More detailed discussions of ceramics from historic sites in the San Antonio area are available in Dial (1992), Fox et al. (1976); Hard et al. (1995), and Meissner (1996). Ceramics can be divided into two major categories, unrefined and refined earthenwares. Unrefined earthenwares have relatively coarse paste textures, and are usually fired at less than $900^{\circ} \mathrm{F}$ (Rice 1987:5). Refined earthenwares have

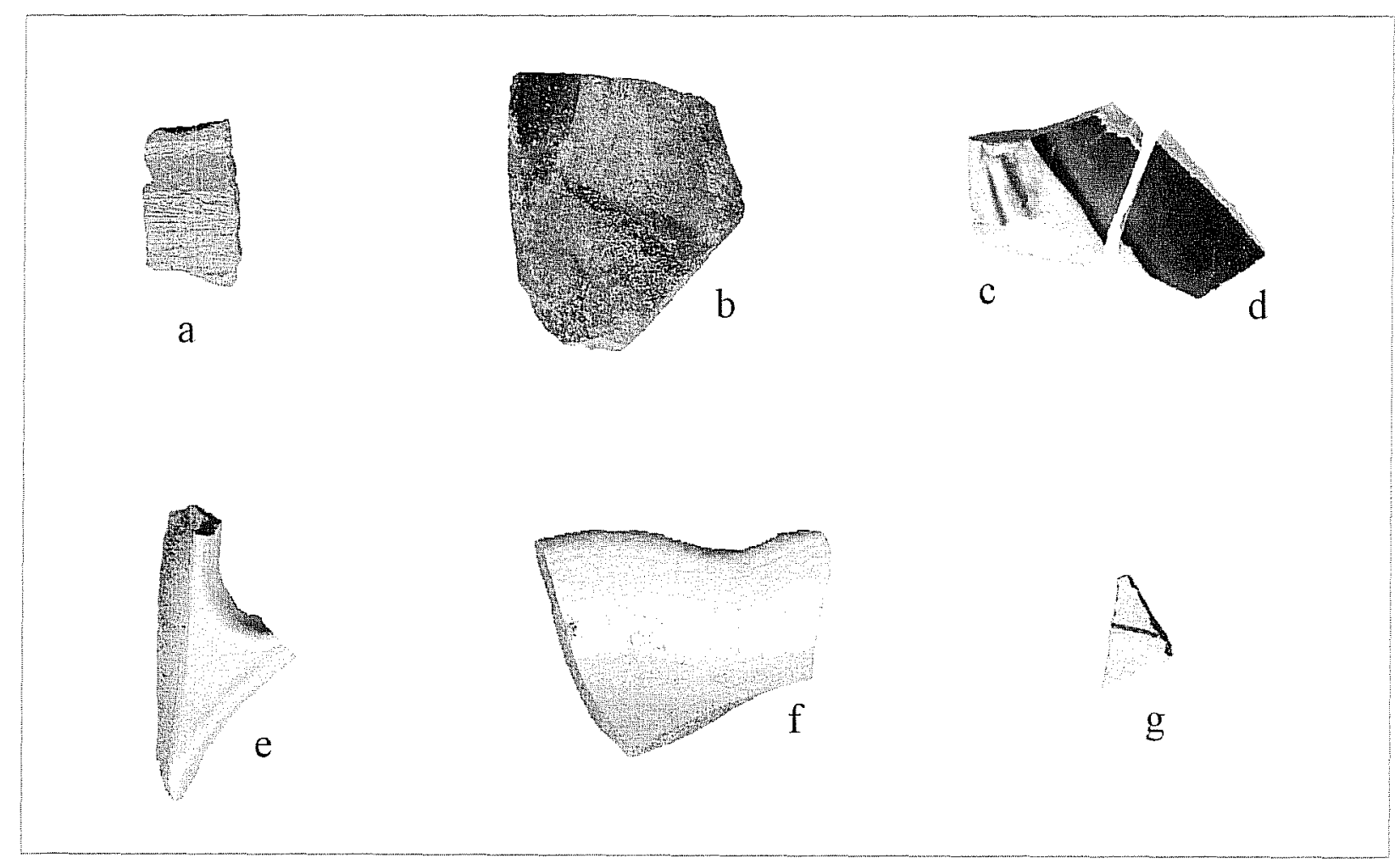

Figure 19. Selected ceramics. a-b) Unrefined earthenwares with partial lead glaze; c-d) late $19^{\text {th }}$ century majolica; e) possible handle fragment in undecorated whiteware; f) undecorated whiteware rim sherd; g) handpainted whiteware. All shown actual size. 
finer-grained paste and are fired at much higher temperatures, which at least partially fuses the clays.

Unrefined Earthenwares. Two unglazed specimens are low-fired body sherds. They could date from the colonial period to the nineteenth century (Ivey and Fox 1981). One (ST4, Level 1) is a fairly thick $(9.2$ $\mathrm{mm}$ ) body sherd. The other body sherd (ST4, Level 1) is thinner $(5.9 \mathrm{~mm})$, and the paste is somewhat more refined.

Two lead-glazed sherds are only partially glazed with a lead-based glaze. One (ST4, Level 1) is the thinwalled type commonly called Galera ware (Figure 19a), which was used for many small bowls and pots in late colonial and post-colonial times, and are occasionally found in stores up to the present (Meissner 1996:64). This body sherd has a partial lead glazing on both sides. The other (ST17, Level 2) is a much thicker sherd with small patches of dark glaze (Figure 19b). This sherd probably dates to the late eighteenth to early nineteenth century (Hard et al. 1995:43).

Two tin-glazed sherds in this collection are a type referred to as "late" or "modern" Majolica (Ray 1974:129). This type of ceramic enjoyed a brief popularity in the late nineteenth century. The first piece (ST4, Level 1) has a molded exterior, with a light green streaked with blue on the raised portion and then a deep blue in the lower portion. The interior is a subdued lavender color (Figure 19c). The other piece (ST4, Level 2), which mends to the first, has the deep blue color on one side and lavender on the other (see Figure 19d)

Refined Earthenwares. Twelve whiteware sherds were found. Whitewares are refined wares with a white to light gray paste, and a thin clear to bluish glaze. They are considered post-colonial in South Texas (Hard et al. 1995:44). One undecorated sherd is molded (ST7, Level 1), and is possibly part of a handle (Figure 19e). Another undecorated sherd (ST9, Level 1) is a rim portion of a shallow platter or large bowl with a scalloped edge (Figure 19f). A third undecorated sherd (ST15, Level 1) is a small fragment that includes a portion of the foot ring of a small plate. Two whiteware sherds were decorated. One is handpainted (ST15, Level 1), a decoration technique most popular in the first half of the nineteenth century
(Dial 1992:41). This sherd is very small, but has a thin reddish line painted across it (Figure 19g). The other sherd (ST4, Level 1) is decal (also called decalcomania), a form of decoration in which a decal is placed over the glaze. This type of decoration was most popular in the late nineteenth century (Hard et al. 1995:47). The decal decoration is often in poor condition when found in an archaeological context, since it is exposed to abrasion and water. This body sherd has a badly worn decal decoration in a dull red color.

Two porcelain sherds also were recovered. Porcelain is made from highly refined kaolin clays and is fired at a very high temperature, which completely vitrifies the clay, making it translucent, and very hard, but brittle (Dial 1992:45). Though porcelains are often decorated, the two sherds from this collection were undecorated.

\section{Bottle/Jar Glass}

A total of 240 pieces of bottle or jar glass were recovered during the project. Most were very small fragments and had no identifying marks.

Five bottle fragments had minimally identifiable marks and are described below. In addition, there were 15 fragments of lavender-colored glass. This glass was originally clear, but a long exposure to sunlight will cause clear glass made with manganese to turn lavender. The practice of using manganese in clear glass was perfected about 1880 and ended in 1915, during World War I, because Germany was the major producer of manganese (Munsey 1970: 55). During the war, selenium was substituted for manganese in clear glass production. The use of manganese in clear glass was not reestablished after the war (Munsey 1970:55). Thus, the 15 sherds of lavender glass can be dated to between about 1880 and 1915 .

Bottle fragments with makers' marks were found in the following STs:

\section{ST5, Level 1}

This specimen is a fragment of the base of a brown bottle about $7 \mathrm{~cm}$ in diameter. The valve mark from a bottle-making machine is commonly seen on bottles dating from the 1930 s to 
the 1940s (Munsey 1970:41). The bottom is embossed with "M..../2630/3/D-9 1/2", but the makers' mark is too fragmentary to permit identification (Figure 20a).

\section{ST12, Level 2}

This fragment is from a $5.2-\mathrm{cm}$ square aqua bottle bottom with a simple, stylized crown embossed on the bottom. The piece was too fragmentary to indicate if it was made in a bottlemaking machine. It is heavily patinated (Figure 20b).

\section{ST18. Level 1}

This fragment of a small, clear, molded glass bowl with a foot ring about $8 \mathrm{~cm}$ in diameter (Figure 20c).

\section{ST28, Level 2}

This sherd is the part of the shoulder of a clear glass bottle embossed with the letters "...ART"

\section{ST35, Level 1}

This specimen is a machine-made, brown glass, oval bottle bottom. Near the base it is lettered "...TD./...TLAND". The bottom is embossed "S569/KX/2/UGB". The UGB mark is from United Glass Containers, Ltd (Figure 20d). The bottle was most likely manufactured after 1937 , when the company acquired several bottling companies in Scotland. The "K" on the bottom may stand for the Kinghorn plant in Kinghorn, Scotland (Toulouse 1971:510-514).
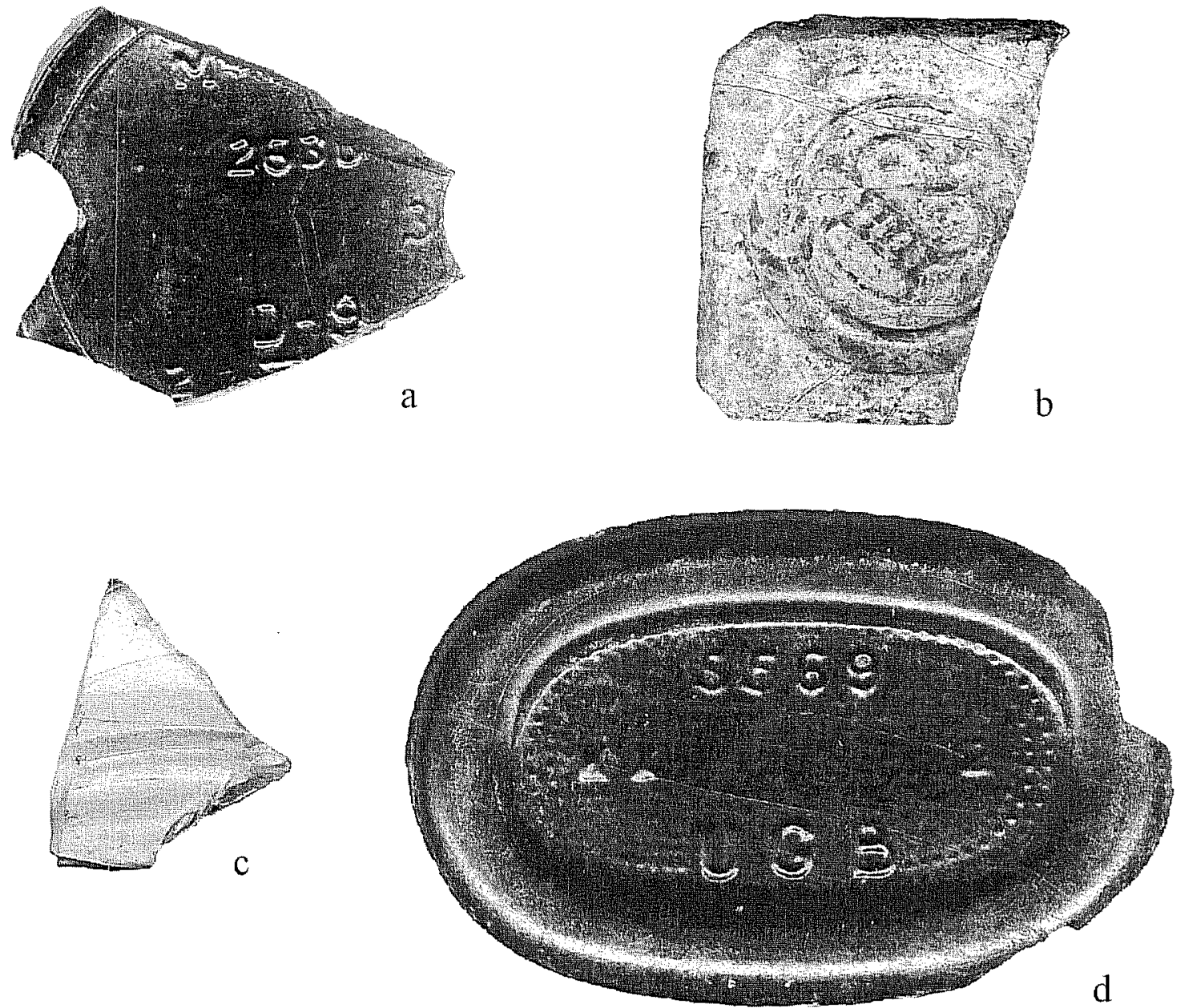

Figure 20. Marked glass fragments. a) brown glass bottle bottom; b) square aqua bottle bottom; c) fragment of glass bowl with foot ring; d) oval brown glass bottle bottom. All shown actual size. 


\section{Other Kitchen/Household Items}

Three pull-top tabs, one crown bottle cap, two flowerpot fragments, and a fragment of light bulb glass which are classified as "other" were also recovered during the project.

Clothing/Personal Items. Three items in this category were recovered. One is a machine-made, freshwater shell button (ST18, Level 3; Figure 21). It has a well and four holes, and the rim is edged with short incised lines set at an angle. The button is small $(8 \mathrm{~mm})$ and probably came from child or baby clothing, although it may be from a lady's glove. It is well made, and probably manufactured sometime between about 1860 and about 1920, most likely in the latter part of that period (Pool 1987:289). A second clothing item was a modern plastic snap (ST2, Level 1), of a type commonly used on cheaply made, lightweight jackets. It appears to have been torn loose, and several prongs are bent.

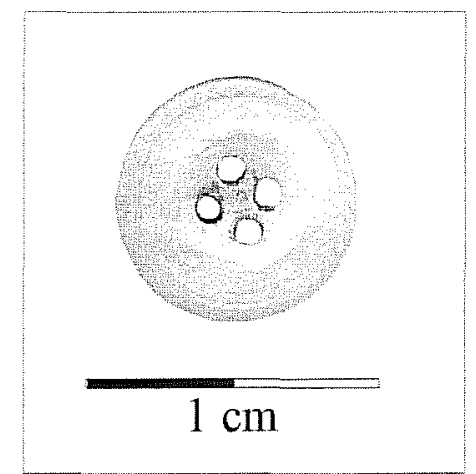

Figure 21. Freshwater shell button.

Shown 3 times actual size.

The third item in this category is the tooth of a comb made from a material known as composition (ST20, Level 1). Composition was used in the nineteenth and early twentieth centuries for many items that are today made of plastic. It was made with very fine wood pulp mixed with glue. This mixture was pressed into molds and hardened (Meissner 1997:166). Composition was largely replaced by the early plastics such as celluloid and Bakelite by about World War I $\mathrm{x}$ (Harpur 1982:30).

\section{Arms}

One brass cartridge casing was recovered (ST18, Level 6). This specimen is a rim-fired .22 caliber short cartridge, probably the most common single cartridge type ever produced (Logan 1959:63). The .22 short cartridge was originally developed by Daniel Wesson for the Smith and Wesson revolver in 1857, and the casing has changed very little since (Logan 1959:63). This cartridge has been fired and is slightly flattened.

\section{Construction}

Only 41 objects related to construction activities were recovered during the project. They are listed by type in Table 8. The paucity of artifacts in this category is consistent with what is known about the history of this part of the park.

Table 8. Construction Artifacts

\begin{tabular}{|l|c|}
\hline \multicolumn{1}{|c|}{ Type } & Count \\
\hline Window Glass & 17 \\
\hline Cut Nails & 10 \\
\hline Wire Nails & 7 \\
\hline Nuts & 1 \\
\hline Tacks & 1 \\
\hline Brick & 3 \\
\hline Tile & 2 \\
\hline Total & 41 \\
\hline
\end{tabular}

\section{Miscellaneous}

There were 68 items which were not placed in any of the categories listed above, most of which were plastic fragments, coal slag and unidentifiable scraps of metal (Table 9). One item was a small copper tag in 2 pieces. The tag measures ca. $1.5 \times 5.75 \mathrm{~cm}$ (roughly $.5 \times 2.5$ inches) and was stamped with several characters, of which only " 36 " are legible.

Table 9. Miscellaneous Historic Artifacts

\begin{tabular}{|l|r|}
\hline \multicolumn{1}{|c|}{ Item } & Count \\
\hline Plastic fragments & 20 \\
\hline Coal & 2 \\
\hline Slag & 20 \\
\hline Metal Scrap & 19 \\
\hline Bakelite & 1 \\
\hline Copper tag & 2 \\
\hline Rubber fragments & 3 \\
\hline Chrome plated tube & 1 \\
\hline
\end{tabular}




\section{Prehistoric Artifacts}

A total of 726 artifacts were determined to be of prehistoric or proto-historic origin. Of these, $674(92.8$ percent) were flakes, the debitage of stone tool manufacture. Two lithic tools can be tentatively assigned to the late-Prehistoric interval.

\section{Lithics}

A total of 12 lithic tools in the form of projectile points, other bifaces, unifaces, utilized flakes, and an indeterminate piece were recovered during the project. The term lithic tool is used here in a very general sense, to mean any stone that was used, or was intended to be used, as a tool. Thus, flakes that were utilized with no preparation are counted, as well as bifaces and unifaces which do not appear to have been finished. Cores which do not appear to have been used as tools, and flakes removed during the lithic reduction process are considered debitage.

\section{Projectile Points}

An arrow point base (Figure 22a) which appears to be a Scallorn preform broken during manufacture was found in ST33, Level 4. The Scallorn point is commonly found in archaeological contexts dating to approximately 1250 to 750 B.P.. (Turner and Hester 1993:230). A pointed biface fragment (Figure 22b) found in ST37, Level 3 exhibits the size and alternate beveling indicative of an arrow point. Determining the cause of the break is not possible. This specimen probably came from the Late Prehistoric interval (ca. 1250 to 420 B.P. [Hester 1995]) but it is too fragmentary to be certain.

\section{Bifaces}

Two bifaces (Figure 22c and Figure 22d) were found in ST4, Level 3 and ST14, Level 3 respectively. Both specimens were broken in an early stage of manufacture, with some cortex remaining on one side. The medial fragment of a thin biface (Figure 22e) found in ST20, Level 2 appears to have been broken during manufacture, and later subjected to considerable heat, as there are several potlid fractures on both sides.

\section{Unifaces}

A unifacial endscraper made on a blade (Figure 22f) recovered from ST17, Level 1 has a minimal amount of retouch along its distal edge. A reworked uniface (Figure 22g), possibly a recycled endscraper, gouge, or adze was found in ST30, Level 2. Two fragments of a unifacially worked flake, which were probably broken by the shovel but mended in the lab (Figure $22 \mathrm{~h}$ ), were found in ST33, Level 3. The mended piece is a possible side-scraper fragment that was subjected to heat and has considerable potlid fracturing.

\section{Utilized Flakes}

A utilized secondary flake (Figure 22i) was recovered from ST30, Level 4, and a utilized tertiary flake, possibly used as a graver (Figure $22 \mathrm{j}$ ), was recovered from ST32, Level 7.

\section{Indeterminate}

An indeterminate angular fragment (Figure 22k) found in ST30, Level 2 is too small to determine if it is part of a biface or a uniface. There is still a small amount of cortex remaining.

\section{Debitage}

Cores

A small core fragment (Figure 23a), with cortex on most of the dorsal side was found in ST7, Level 6. A single-faceted polyhedral core (Figure $23 \mathrm{~b}$ ) with part of the cortex is still extant was recovered from ST32, Level 4, and a core made from a small cobble (Figure 23c), with part of the cortex remaining was found in ST33, Level 1. Finally, a core fragment (Figure 23d) was found in ST34, Level 6.

\section{Flakes}

During the project 674 flakes remaining from stone tool manufacturing activities were recovered. Each piece was examined and data on material, flake type, size category, whether the flake was from biface thinning, and whether the flake exhibited potlid fractures indicative of exposure to heat, were recorded. This data is presented in Appendix C. 


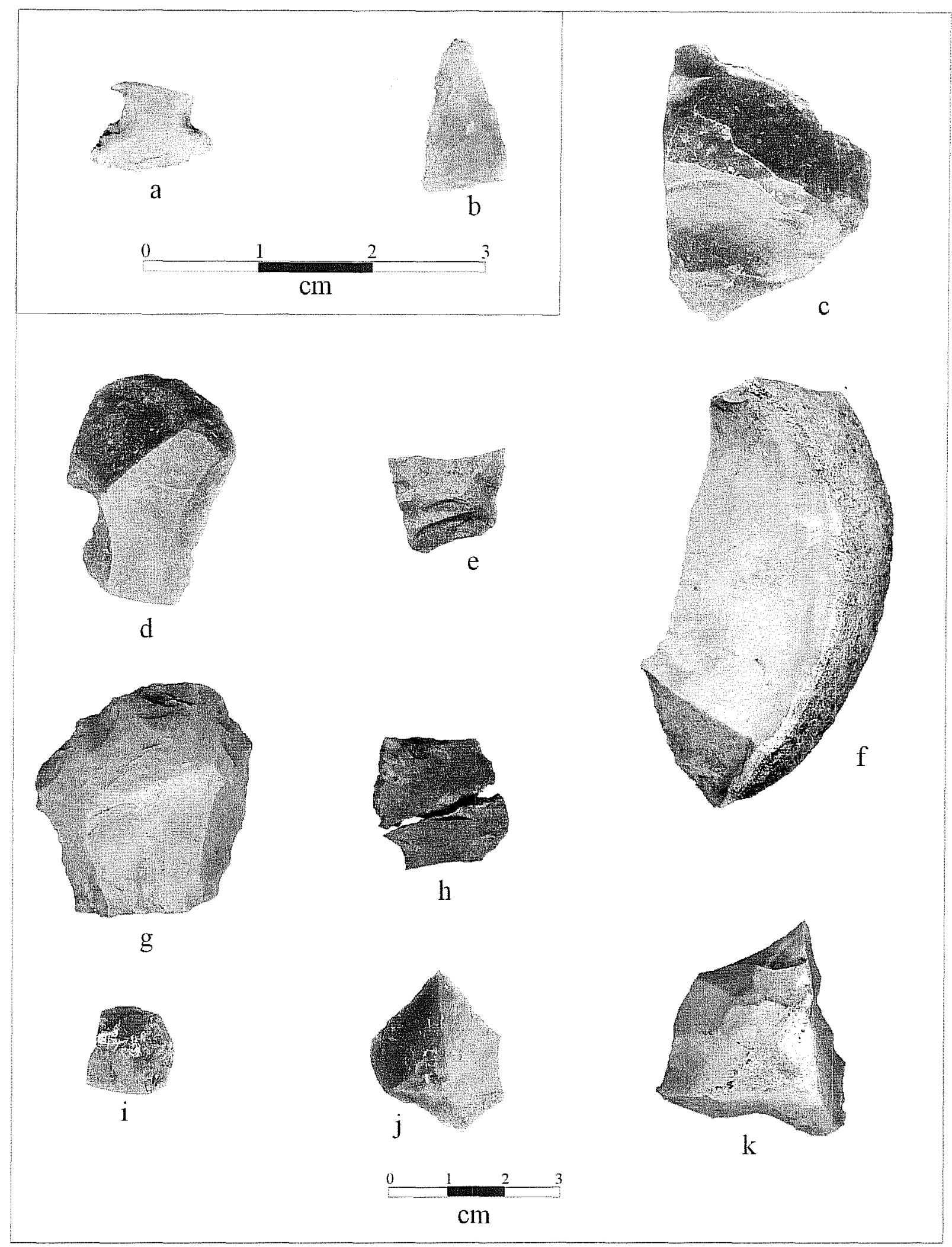

Figure 22. Lithic tools. a) Scallorn preform base; b) arrow point tip; c-d) bifaces broken during early manufacture; e) thin biface fragment; f) unifacial endscraper; g) reworked uniface; $h$ ) two uniface fragments that mend; i) utilized secondary flake; j) utilized tertiary flake; $k$ ) angular fragment. 


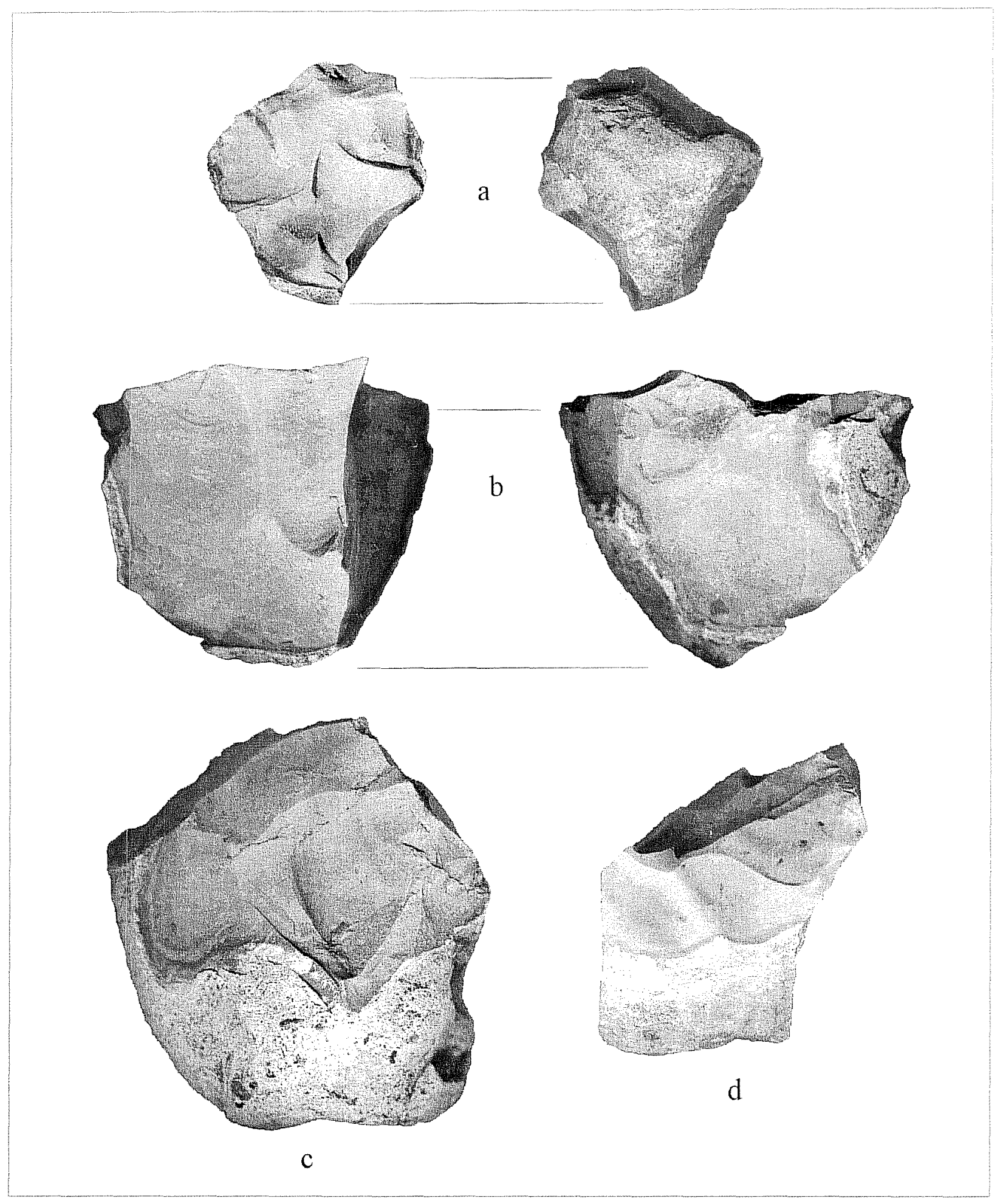

Figure 23. Cores and core fragments. a) small core fragment; b) polyhedral core; c) small core; d) core fragment. All shown actual size. 
Six flakes were made of quartzite; all others were made from chert. The chert occurs in a wide range of colors, from a pale tan to nearly jet black, including pinks and grays; most of the chert, however, was the shades of brown common in Edwards Plateau cherts found in the area, especially a few kilometers north of the park, along the Balcones Escarpment (Barnes 1983; Nickels 1998; Potter et al. 1992).

A common method of estimating the stage of lithic reduction during which debitage was created is by noting the flake type, i.e., the amount of cortex left on the flake. For this analysis, a primary flake is defined as one that retains cortex on 100 percent of the dorsal surface of the flake. A secondary flake retains some, but less than 100 percent cortex, on the dorsal surface. A tertiary flake retains no cortex. The flake types from this collection are shown in Table 10 . The ratio of the three flake types is typical for a prehistoric occupation site, but not a colonial period site (Hard et al. 1995:54; Uecker 1992:66, Table 7).

Table 10. Flake Types

\begin{tabular}{|c|c|c|}
\hline Type & \# & $\%$ \\
\hline Primary & 31 & 4.6 \\
\hline Secondary & 138 & 20.5 \\
\hline Tertiary & 505 & 74.9 \\
\hline Total & 674 & 100.0 \\
\hline
\end{tabular}

Each flake was assigned to a size category according to the smallest of a series of circles within which it would entirely fit. The smallest circle (Category 1) was $.5 \mathrm{~cm}$ in diameter, and each succeeding circle was $1 \mathrm{~cm}$ larger in diameter. Thus, Category 3 was $2.5 \mathrm{~cm}$ in diameter, and Category 6 was $5.5 \mathrm{~cm}$ in diameter. No Category 1 flakes were recovered, which is not surprising considering that flakes that small would have easily gone through the $1 / 4$-inch screens that were used in this project. Figure 23 illustrates that the great majority of flakes are quite small. In fact, 83.2 percent $(n=561)$ fit inside a circle only $2.5 \mathrm{~cm}$ in diameter (i.e., were either Category 2 or 3 ). A total of 14.8 percent $(n=99)$ of the flakes can be characterized as biface thinning flakes. The small size and the large percentage of tertiary flakes suggests that the early stages of tool manufacture were not, in general, being carried out at the site. The final stages of tool manufacture and the resharpening of tools seems to have been the major lithic work being performed at the site.

\section{Other Prehistoric Items}

Seven pieces of ocher, six of which mend into a single large piece, were recovered from the shovel tests. The large piece is a rough square measuring about $5 \mathrm{~cm}$ on a side, and about $1.4 \mathrm{~cm}$ thick (Figure 24). One of the flat faces exhibits slight grinding, suggesting that the ocher piece was used at least once before it was lost or discarded. Ocher is a soft, naturally occurring mineral, usually a mixture of the iron oxides hematite and limonite. It can range in color from lemon yellow through bright orange, to a deep red. Ocher is usually soft enough to mark the skin when drawn across it. It can easily be ground to form the tint for painting. The bright colors seem to have been popular in the prehistoric period, as ocher is often found in prehistoric sites (Tomka et al. 1997a:3-51, 3-54). Cabeza de Vaca tells of trading ocher among various inland and coastal groups (Smith 1966 [1871]), and the diary of the 1709 Aguirre entrada mentions the "red and yellow dirt with which the Indians paint their hides" (Tous 1930:12).

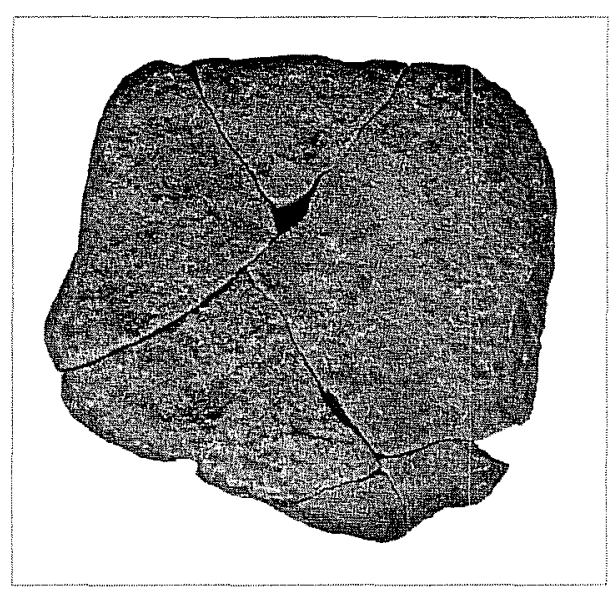

Figure 24. Large piece of ocher in six pieces. Shown actual size. 


\section{Private Collection Donated to CAR}

During the project, the CAR field crew was approached by a private collector who indicated he had picked up stone tools in the park on several occasions in the past. He showed the project archaeologist where he had found them, in an area near the main springs, adjacent to the restored part of the Alazán acequia. In that area the CAR crew observed numerous chert flakes and a few pieces of refined ceramics. The next day, the individual returned and donated the collection of lithics to CAR. They include three projectile points Figure 25a-c), three other bifaces (Figure 25d-f), and a utilized flake (Figure 25g).

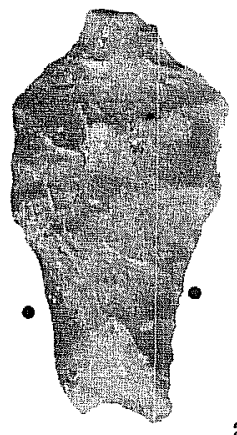

a

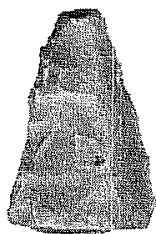

d

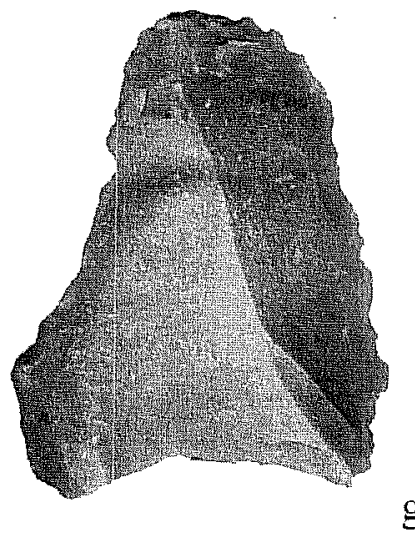

g
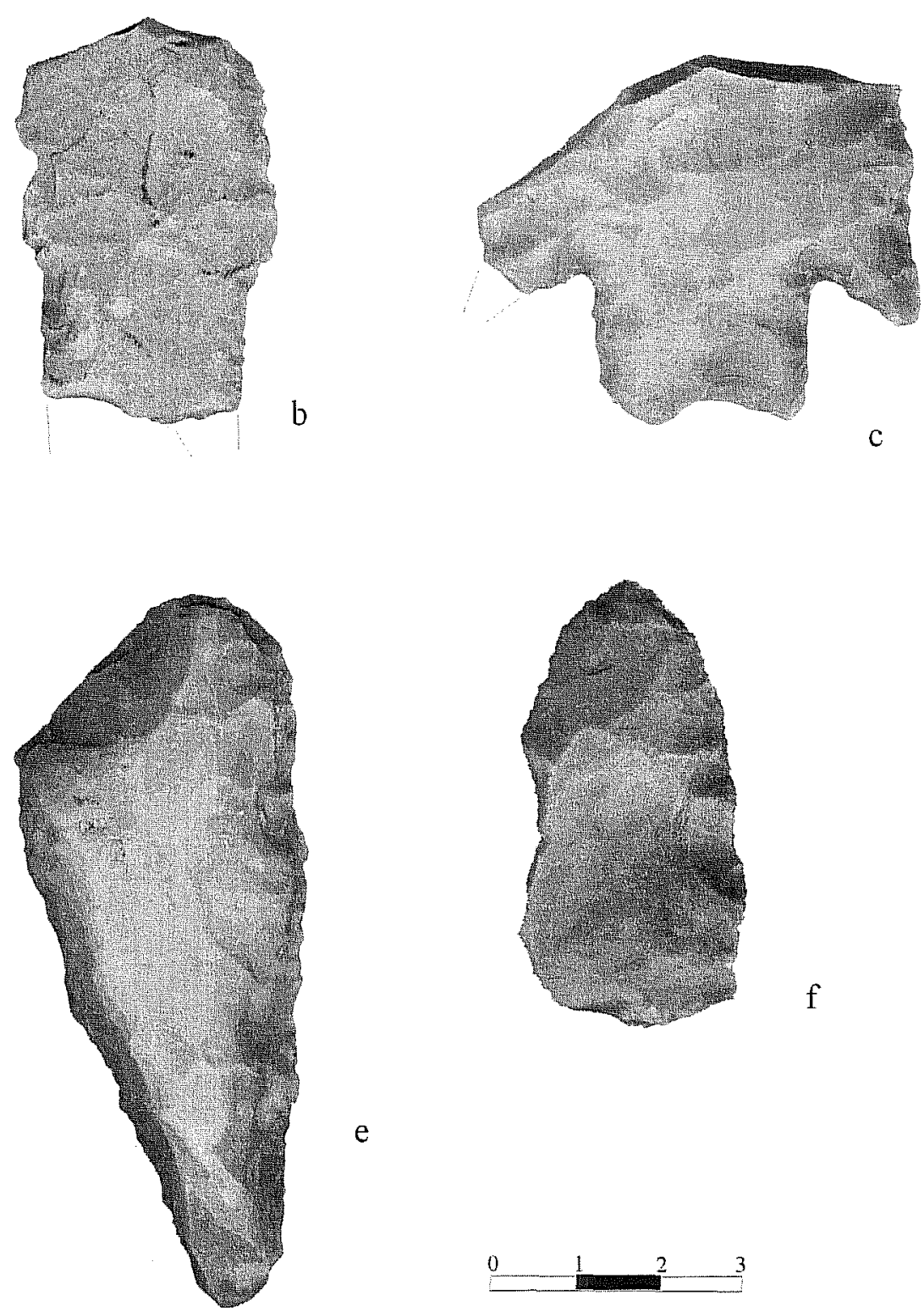

f

e

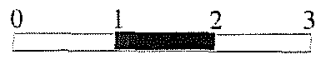

$\mathrm{cm}$

Figure 25. Lithics from area near the main springs. a) "Orchard" point; b) Pedernales point; c) Marshall point; d) distal tip of point; e) reworked gouge; f) small broken gouge; g) utilized flake. 


\section{Projectile Points}

Of particular interest are the three diagnostic projectile points in the collection. One of these is similar to a point type proposed more than 20 years ago (Mitchell 1976), but never completely accepted: the Orchard point (Figure 25a). The Orchard point is considered to be late-Paleoindian in age and has similar morphological characteristics as Angostura, Golondrina, and Rio Grande points. However, unlike Angostura and Hell Gap types, the Orchard has recurved lower edges, and unlike the Rio Grande type, the Orchard has a flaring and concave base. Specifically, the Orchard point as proposed by Mitchell (1976) has an...

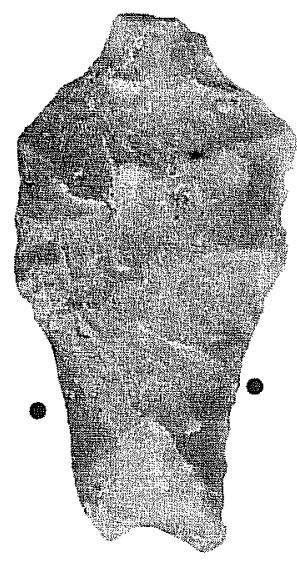

$$
\begin{gathered}
\text { "alternately beveled proximal... } \\
\text { narrow waisted stem... recurved lower edges... } \\
\text { outward flared basal corners with concave to } \\
\text { recurved basal edge, and... } \\
\text { smoothing on both lower edges and base" }
\end{gathered}
$$

(Mitchell 1976:21).

As indicated in the enlarged version above and in Figure 25a, the specimen examined in the donated collection demonstrates all of these attributes.

The second point is a broken Pedernales point (Turner and Hester 1993:171; see Figure 25b). This point shows some evidence of having been reworked, but the break causes are indeterminate. The third point is a Marshall point (Turner and Hester 1993:149; Figure 25c). The breaks on this point appear to be postdepositional. Both of these points are believed to have been manufactured during the Middle Archaic and/or Late Archaic intervals (Black 1995; Collins 1995).

\section{Other Bifaces}

In addition to the diagnostic points, three other bifaces are in the collection. One is the distal tip of a dart point (Figure 25d). Both the most distal portion and the proximal end show impact fractures. The second biface is plano-convex in shape, and was probably used as a gouge (Figure 25e). It appears to have been reworked along one edge. The third biface (Figure 25f) was probably also a small gouge, but was broken during manufacture or resharpening. 


\section{Vertebrate Faunal Remains}

A total of 91 bones and bone fragments were collected during the project. Of these only 12 (13.2 percent) were identifiable to the genus taxonomic level, including both domestic and non-domestic animals (Table 11). They were identified using the comparative collection at CAR. A provenienced listing with observation details on all bone recovered can be found in Appendix B.

This small collection tells us little about the use of animals in the area around the springs. It is difficult to determine if the small sample size is due to poor preservation of faunal material, or if there was little or no bone originally deposited in the study area. Poor preservation of faunal material is a perennial problem in South Texas (Meissner et al. 1998; Tomka et al. 1997b) due to a combination of factors, including both cultural and non-cultural taphonomic processes. However, only 9.9 percent $(n=10)$ of the bone in this collection shows the pitting on the bone surface commonly attributed to chemical weathering, a major environmental cause of poor bone preservation in the region (Meissner et al. 1998:198-199; Shaffer 1995). Most of the bone in this collection is very fragmented, with the average weight of only $1.45 \mathrm{~g}$. This may be due to a number of factors, but is often attributed to human processing of bone to extract marrow and bone grease (Meissner 1998a; Tomka et al. 1999). Butcher marks on the bone include saw cuts, usually considered a nineteenth-century or later technique. One bone was machine sawed, definitely a twentieth-century butchering technique. Of the identified taxa, only the deer and the horse are not likely to have been deposited in the site in recent years. Most of the bone is highly fragmented, but much of the bone that is not fragmented is in fairly good condition, indicating the possibility that human rather than environmental factors are responsible for the bone fracturing.

\section{Conclusions and Recommendations}

Previous excavations within the park were limited to a small section of the Alazán acequia east of the springs (Fox 1978). This project, originally intended to estimate the likelihood that the SARA drainage project would disturb important cultural deposits as the construction proceeded up North Flores Street, was the first to examine the sub-surface deposits across a larger portion of the park. By allowing the tests to be conducted alongside North Flores, inside the park itself, the Department of Parks and Recreation gained important information about possible cultural resources in the park adjacent to North Flores.

Table 11. Taxa Identified

\begin{tabular}{|c|c|c|c|c|}
\hline Taxon & \begin{tabular}{|c|} 
Common Name \\
\end{tabular} & Ct. & Wgt. (g) & Notes \\
\hline Bos taurus & Cattle & 1 & 15.87 & \\
\hline Capra/Ovis & Goat/Sheep & 1 & 1.87 & $\begin{array}{l}\text { It is often difficult to differentiate these two } \\
\text { genera. }\end{array}$ \\
\hline Crotulus atrox & $\begin{array}{l}\text { Western diamondback } \\
\text { rattlesnake }\end{array}$ & 1 & 0.55 & \\
\hline Equus caballos & Horse & 1 & 40.27 & \\
\hline $\begin{array}{l}\text { Odocoileus } \\
\text { virginianus }\end{array}$ & Whitetail Deer & 2 & 3.75 & \\
\hline Sciurus cf. niger & $\begin{array}{l}\text { Squirrel (cf. Eastern Fox } \\
\text { Squirrel) }\end{array}$ & 1 & 0.89 & $\begin{array}{l}\text { S. niger is by far the most common tree squirrel } \\
\text { in the area today. }\end{array}$ \\
\hline Sus scrofa & Domestic Pig & 3 & 4.8 & \\
\hline Sylvilagus sp. & Cottontail rabbit & 2 & 0.19 & $\begin{array}{l}\text { The range of three species ( } S \text {. floridanus, } S \text {. } \\
\text { aquaticus, and } S . \text { audubonii) overlap in the area } \\
\text { (Davis and Schmidly 1994). }\end{array}$ \\
\hline 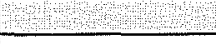 & Total NISP & 12 & 68.19 & W174. \\
\hline Artiodactyl & Deer/Goat/Sheep & 4 & 18.22 & \\
\hline Mammalia & Mammals & 71 & 44.15 & \\
\hline Aves & Birds & 3 & 1.23 & \\
\hline Testudinae & Turtles & 1 & 0.15 & \\
\hline B७? & Total Bone & 91 & 131.94 & Whate \\
\hline
\end{tabular}


An analysis of historic artifact distribution along the western edge of the park from north to south reveals that generally, the greatest density of historic artifacts occurs from 0 to $10 \mathrm{~cm}$ below the surface (Level 1), and quantities decrease with increased depth of excavation (see Table 6 and Figure 16). Examination of the artifact counts by level indicates that the distribution generally decreases in quantity from north to south. The data suggest that there may be areas of intact historic cultural deposits from 50 to $60 \mathrm{~cm}$ below the surface around STs 5 and 23.

The single identified historic feature was the remains of the Alazán acequia (Figure 14). This project was able to add more information about the history of the old ditch. The discovery that the acequia had been cut nearly a meter into the bedrock underscores the nature of the problems that are known to have plagued the acequia from its beginning. It now appears that most of the problems encountered during the construction and use of the acequia arose from the basic approach to the design. The early 1700 s Spanish acequias in San Antonio were constructed to conform to the natural land contours, and utilized slope and gravity to conduct the water on its course with a minimum of modification of landform, and thus, a minimum of construction effort. However, in the late-1800s German design of the Alazán, Friesleben insisted on making the course of the water conform to his intended route, despite problems with the natural contours of the land. Evidence of this can be seen in the excavation of the acequia into the bedrock in the western part of the park, as well as the need to build a tunnel to lower the course of the acequia west of the park (Nickels and Cox 1996). This kind of modification has not been seen elsewhere in acequias of Spanish design.

An analysis of prehistoric artifact distribution along the western edge of the park from north to south reveals that a site is present along the entire western edge of the park, and that generally, the density of artifacts increases significantly on the southern end of the park (Figure 17), with the greatest density of prehistoric artifacts occurring from 20 to $40 \mathrm{~cm}$ below the surface in that area (Figure 18). The relatively high densities of fire-cracked rock in Levels 3 and 4 of STs 29 and 30, provide further evidence of potentially intact cultural deposits in those levels, in that discrete southwestern portion of the park.
The artifacts which were donated by an individual who had collected them from an eroded surface in the eastcentral part of the park indicate that there may still be prehistoric cultural deposits in that region as well. The presence of a range of projectile point types dating from the Early Archaic through the Late Archaic periods suggests that the area around the springs was possibly occupied throughout that 7,000-year period.

\section{Conclusions}

During this testing project, only scattered historic artifacts were recovered, most of which were in the upper $30 \mathrm{~cm}$ below the ground surface. Prehistoric artifacts were found to extend as deep as Level 7 (70 $\mathrm{cm}$ below ground surface) in 9 of the 38 tests. However, the single potentially intact prehistoric component found in STs 29 through 34 was generally confined to Levels 3 and $4(20-40 \mathrm{~cm}$ below the surface). By comparing the current level of North Flores Street with the ground surface at various points along the project area, it was determined that any archaeological deposits that may have been present underneath North Flores have probably been disturbed by road construction in the past. There is, however, a possibility that cultural deposits below $70 \mathrm{~cm}$ may be encountered. Because of this possibility, we recommend that an archaeologist monitor the construction of the drainage project as it extends up North Flores.

We also recommend that any renovations or new construction inside San Pedro Park be preceded by a program of archaeological testing. Such tests should be adequate to determine the nature of both historic and prehistoric deposits and the extent to which such deposits have been disturbed by previous construction. The cultural history of San Pedro Park is an important part of the cultural history of San Antonio, and deserves to be managed with care. 



\section{Chapter 4: The 1998 Investigations}

\section{Brett A. Houk, David L. Nickels, and Barbara A. Meissner}

\section{Introduction}

This section provides a description and analysis of an archaeological testing project conducted in April 1998 in the southwest corner of San Pedro Park (Figure 26).

The purpose of the 1998 project was to assess any damage to buried cultural materials caused by heavy equipment and construction fill stored in that area (see Figure 2). For comparative purposes, it was necessary to gather information on the undisturbed part of southwest corner as well as the disturbed area. The assessment included shovel testing, excavation of 1$\mathrm{x}-2 \mathrm{~m}$ units by hand, and the subsequent analysis of the artifacts recovered.

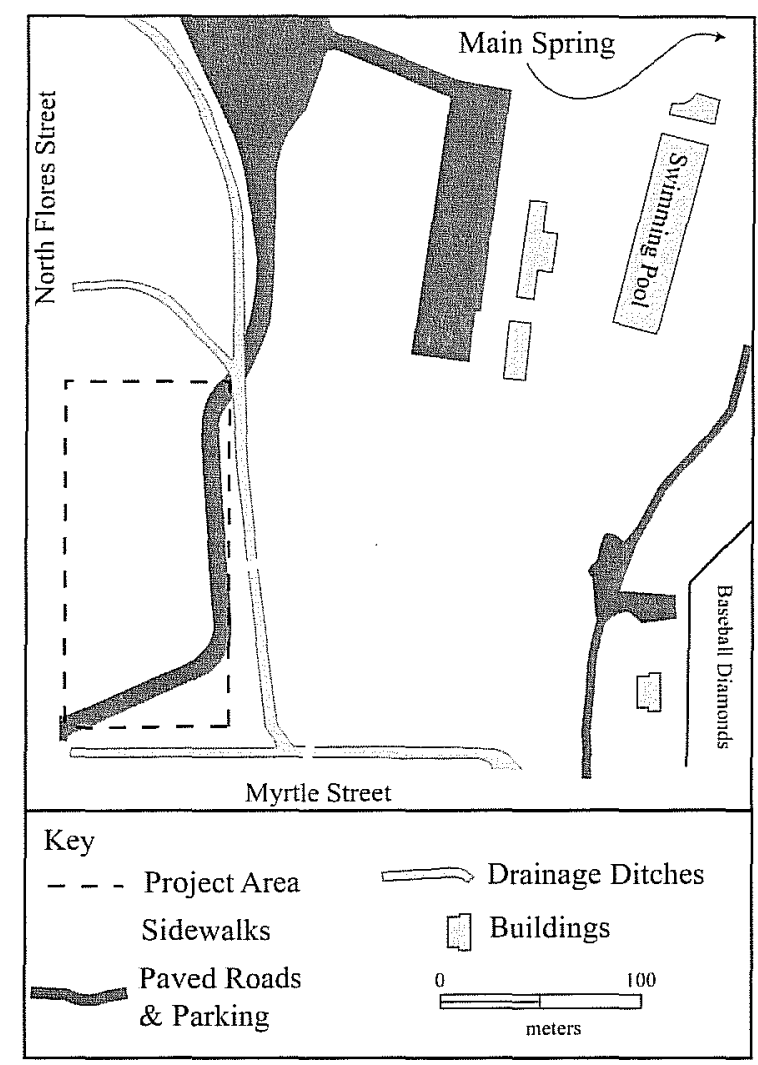

Figure 26. Southwestern corner of San Pedro Park, showing location of 1998 project.

\section{Methods}

\section{Surface Inspection and Gridding}

CAR personnel conducted an inspection of the project area to determine the approximate horizontal extent of the impact area. While grass had begun to grow over the disturbances, it was sparse, and mapping the extent of the distribution of a reddish sandy loam and a white gravel matrix on the ground surface, thought to be related to the removal of the stockpiled materials and clean-up of the area, was easy (see Figure 3). Approximately 2,640 $\mathrm{m}^{2}$ of the surface was covered by either the white gravel or reddish sandy loam material (Figure 27). A grid measuring $70 \times 30 \mathrm{~m}\left(2,100 \mathrm{~m}^{2}\right)$, aligned north-south, was established in the project area. The northern section of the grid, approximately 525 $\mathrm{m}^{2}$, extended beyond the perceived north extent of the disturbed area.

\section{Shovel Testing}

Shovel tests (STs) were placed at 10-m intervals on the grid and excavated in $10 \mathrm{~cm}$ levels to a depth of at least $50 \mathrm{~cm}$ below surface (bs). If artifact densities were high in the fifth level, an additional 10 $\mathrm{cm}$ level was excavated. Based on the results of the initial 32 shovel tests, eight more shovel tests were excavated to define more fully the northern extent of the disturbed area (see Figure 27).

All cultural material, including modern debris, was collected from the shovel tests and returned to the CAR laboratory for processing and analysis. The soil or sediment, artifact contents, and degree of disturbance of each shovel test level was documented on a specially prepared form. Each shovel test was backfilled after the final level had been described. 


\section{Mapping}

The disturbed area, shovel tests, and excavation units were mapped using a total data station. The location and surface elevation of each shovel test was related to vertical and horizontal control points established in the park by SARA. This allowed the location of the shovel tests to be plotted on SARA's map of the park (created as part of the larger Ashby Street improvement project). It also allowed for comparisons of the elevation of the ground at various points at the time of testing with the pre-impact contour map of the park.

\section{1-x-2 m Excavation Units}

Five 1-x-2-m test units (TUs) were placed in a line, forming a discontinuous profile of the project area (Figure 27). Three units (TUs 1-3) were excavated at the north end of the grid, spaced four meters apart, to sample the least disturbed sections of the project area. TU 1 was placed near the north end of the shovel test grid approximately $8 \mathrm{~m}$ northwest of a large pecan tree. The grass in this area appeared to be mature and undisturbed by stockpiling activities. This location was selected to sample an area believed to be free of impact and known to have high artifact counts based on the shovel testing. TU 2 was located $4 \mathrm{~m}$ south of TU 1 , approximately $6 \mathrm{~m}$ west of the large pecan tree. As with TU 1 , this unit was placed in an area with mature grass. TU 3 was placed $4 \mathrm{~m}$ south of TU 2, approximately $6 \mathrm{~m}$ southwest of the large pecan tree. Two units (TUs 4 and 5) were placed in the south end of the grid to sample the disturbed area. TU 4 was excavated $16 \mathrm{~m}$ south of TU 3 , and TU 5 was placed $13 \mathrm{~m}$ south of TU 4.

Units were excavated in $10 \mathrm{~cm}$ levels to a depth of 50 $\mathrm{cm}$, except the south $1-\mathrm{m}$ section of TU 5 , which was excavated to a depth of one meter. Matrix from excavation levels containing potentially intact cultural deposits was screened through $1 / 4$-inch wire mesh. Levels containing construction gravel were not screened. Artifacts were collected by unit and level and returned to the CAR laboratory for washing, cataloging, and analysis. Burned rock was collected, counted, and weighed by excavation unit and level. The east wall of each excavation unit was profiled and photographed, except TU 3 (which was abandoned after the first level was completed). The excavation units were then backfilled.
Figure 27. Map of 1998 project area, showing evidence of surface disturbances (red sand or gravel) in gray. Also shown are 1998 shovel tests and test units, and 1996 shovel tests and backhoe trench.

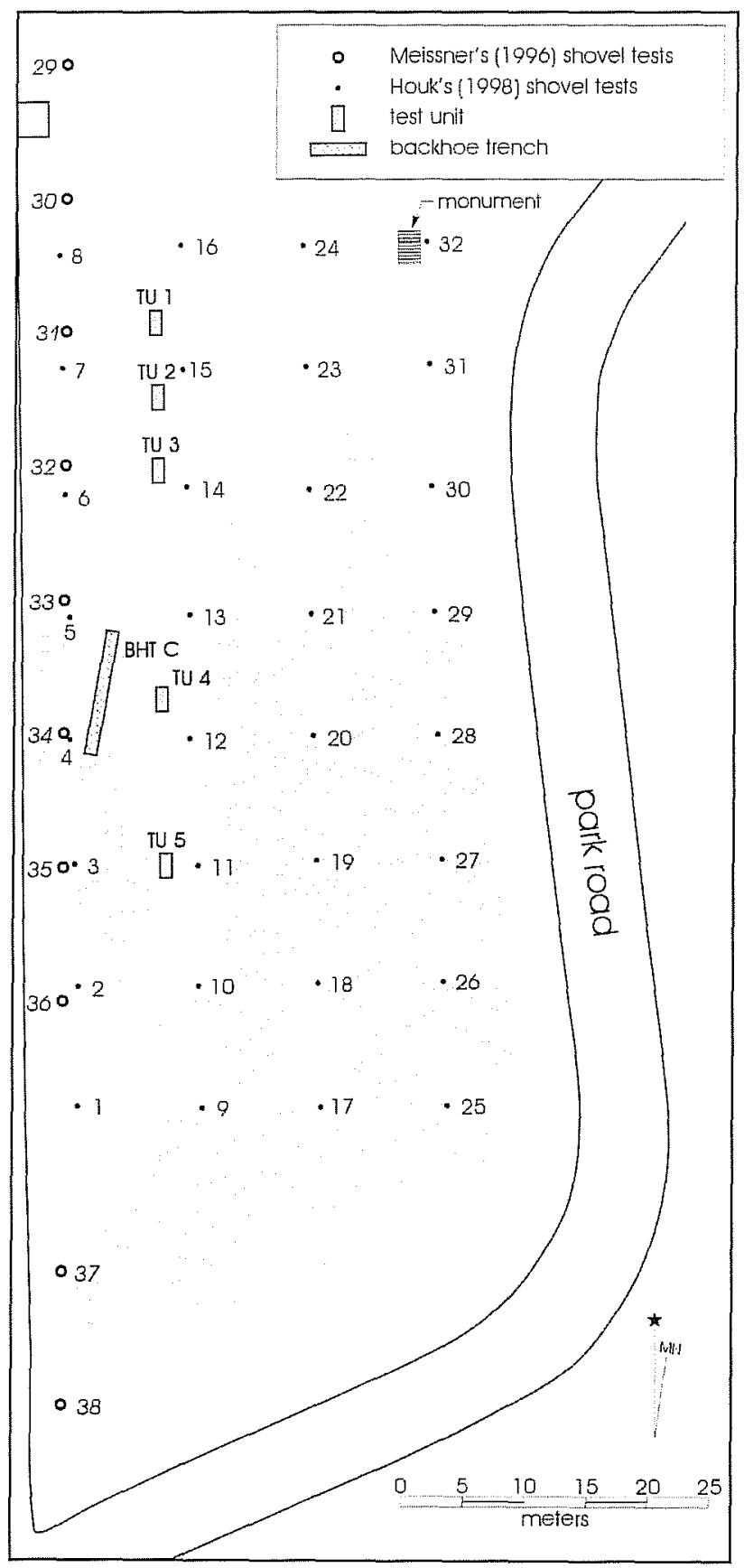




\section{Results}

\section{Shovel Testing}

The initial shovel testing investigations provide three important types of information about the project area. First, they establish the thickness of foreign material (gravel or sandy loam) covering the native clay loam. Second, they provide data on the structure of the native clay loam. Third, the shovel tests provide horizontal and vertical artifact distribution data. With respect to the first two issues, the shovel tests encountered five types of material at varying depths:

1) Construction-related sandy loam;

2) Construction-related gravel;

3) Construction-related sand;

4) Clay loam; and

5) Compacted clay loam.

The compacted clay loam is very distinctive and easily recognized during excavation. The unaltered clay loam in San Pedro Park is characterized by a blocky texture. In the compacted clay loam, the blocky texture has been so compressed that the material exhibits an almost conchoidal fracture pattern when excavated or broken by hand.

In most units, more than one type of matrix was encountered. Figure 28 is a schematic representation of the vertical distribution of these materials within the shovel test grid. Figure 29 is a plan map with the approximate distributions of these materials as they occur on the surface and includes data from the eight additional shovel tests that were excavated after the grid was completed.

The thickness of the foreign material varies from unit to unit. In STs 8, 16, 20,27, and 28, the foreign gravel material extended the entire depth of the shovel tests. Generally, however, the overlying gravel, sand, or sandy loam was between 10 and 20 $\mathrm{cm}$ thick. ST 8 was placed within two meters of Meissner's ST 31 (see Chapter 3), a unit which also encountered artificial fill through $50 \mathrm{~cm}$ below the surface. The disturbance encountered in STs 8 and 16 , and possibly that in STs 24 and 32, may predate the Ramex impact to the southwest corner.
Excluding the five shovel tests with solid fill, compacted clay was encountered in every unit except STs $1,15,23,29,33,38$, and 39 . The thickness of the compact layer ranged from approximately 10 to 20 $\mathrm{cm}$. The first pattern evident in the shovel test data is that the ground near either the large pecan tree or the cluster of small oak trees is not compacted. The rest of the area sampled by the shovel test grid, however,

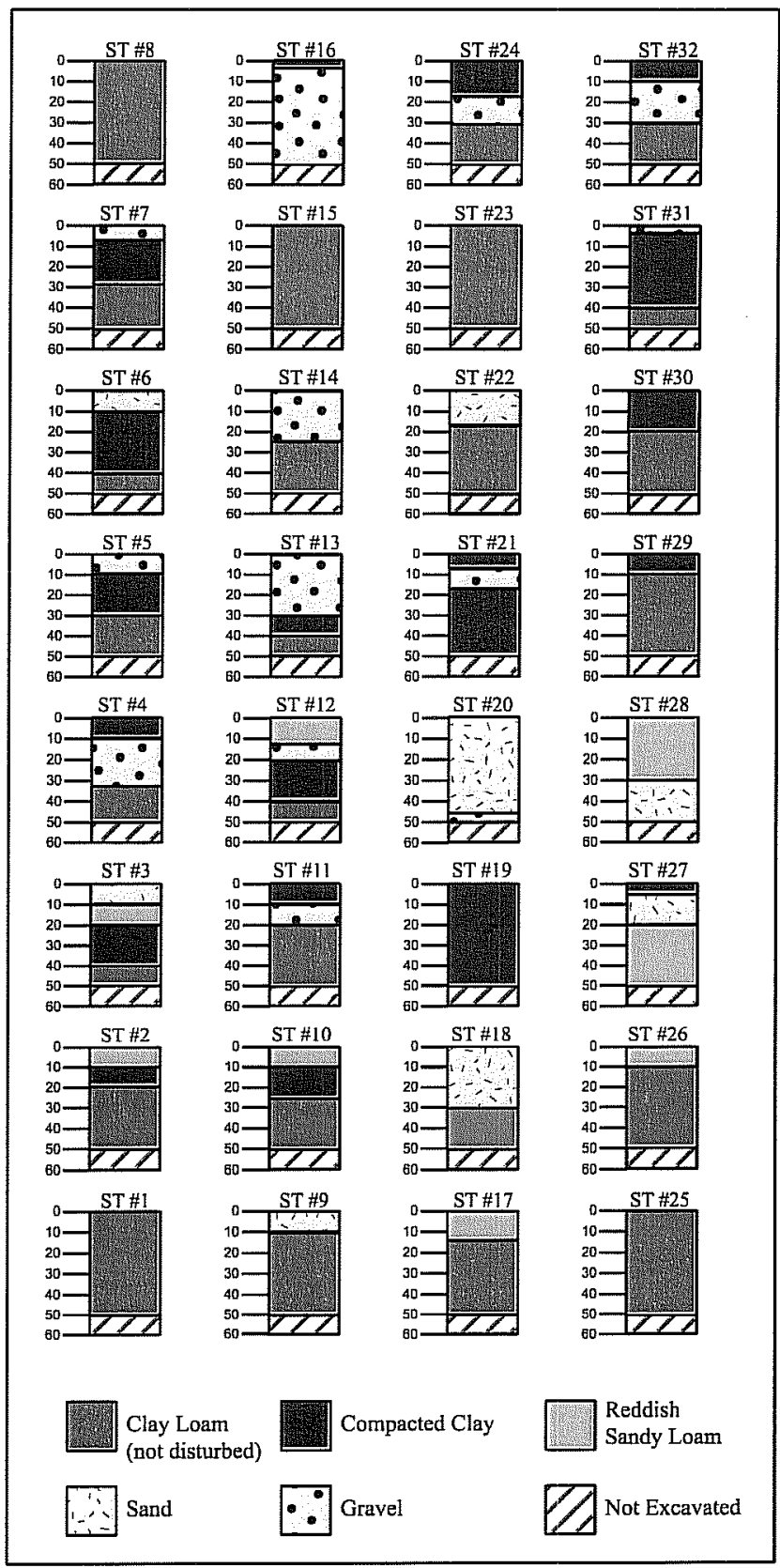

Figure 28. Schematic representation of the vertical distribution of soils and sediments in 1998 shovel tests. 
has been disturbed, through compaction, the introduction of construction-related fill, or a combination of the two.

Additional disturbance to the project area is indicated in the artifacts collected from the shovel tests (Table 12). Modern or historic debris was encountered in Level 3 of ST 25, Level 4 of ST 3, Level 4 of ST 32,
Levels 4 and 5 of ST 29, and Level 5 of ST 18. It is not possible to determine the source of this subsurface disturbance. Sections of the southwest corner were disturbed in the past. For example, as is discussed in detail below, a sprinkler and associated water pipe installed in the 1960 s by the Parks and Recreation Department were encountered in TU 4.

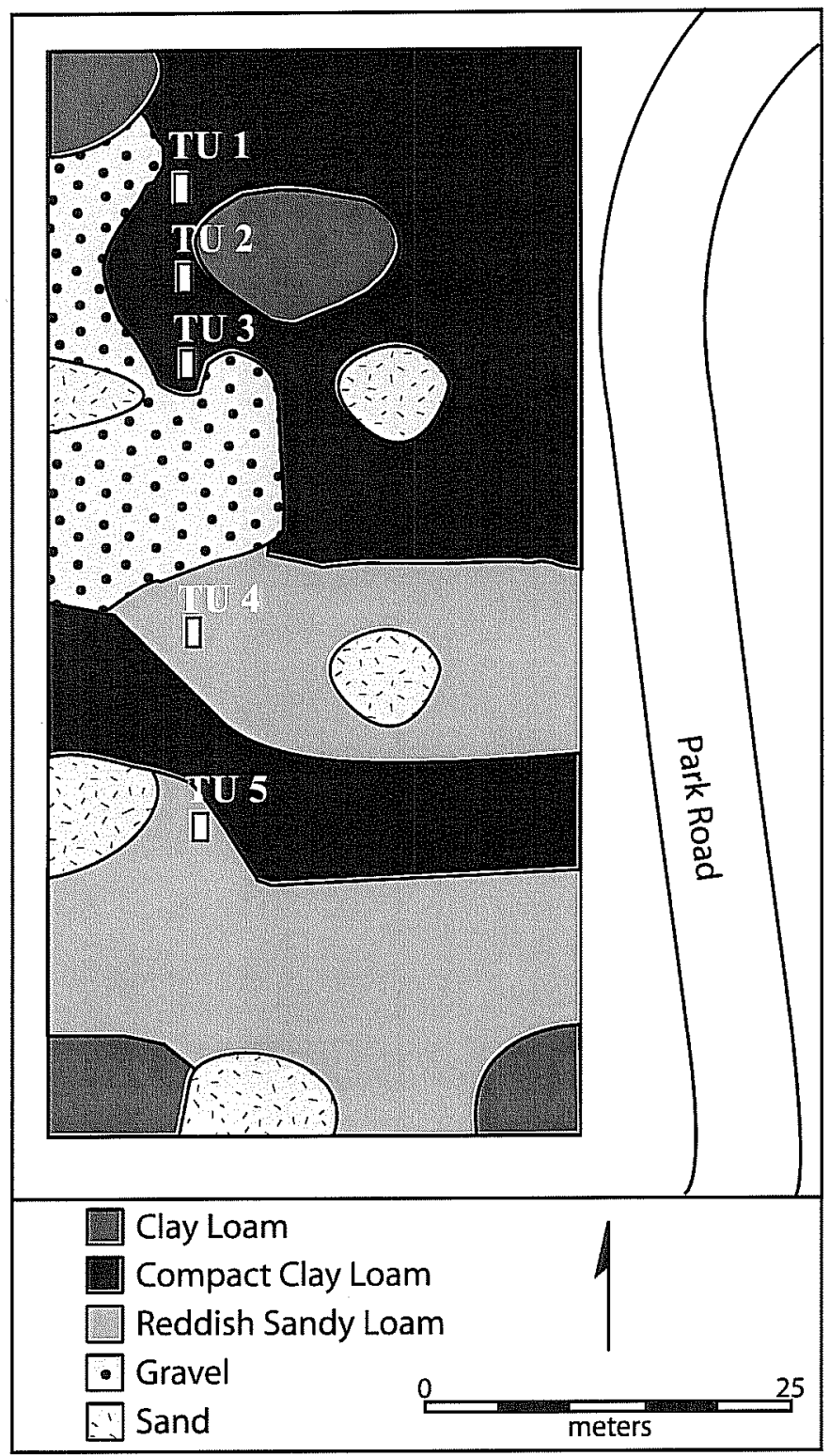

Figure 29. Plan map of project area with the approximate distribution of soils and sediments as they occur on the surface. 
Overall, the prehistoric artifact counts in the shovel tests are lower than those documented by Meissner's excavations adjacent to North Flores Street (compare Table 12 to Table 2). Meissner encountered high artifact counts (averaging between 27 and 177 prehistoric artifacts in Levels 3 and 4) in her STs 29, 30, 32, and 33 (see Figure 17). The highest artifact counts from this phase of the project were found in STs 7, 14, 15, $17,34,36,37$, and 40 . With the exception of ST 17, which may have encountered a buried burned-rock feature at the south end of the shovel testing grid, the highest artifact counts were encountered in the north end of the project area, east of Meissner's most prosperous shovel tests.

Table 12. Artifacts Recovered in 1998 Shovel Tests

\begin{tabular}{|c|c|c|c|c|c|c|c|}
\hline \multirow{2}{*}{$\begin{array}{l}\text { Level } \\
\text { ST\#1 }\end{array}$} & $\begin{array}{c}\text { Sediment } \\
\text { Color }\end{array}$ & Sediment description & 资 & 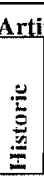 & 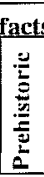 & 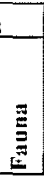 & Comments \\
\hline & & & & & & & \\
\hline \multirow{5}{*}{$\begin{array}{r}1 \\
2 \\
3 \\
4 \\
5\end{array}$} & \multirow[t]{5}{*}{$10 \mathrm{YR} 3 / 1$} & \multirow[t]{5}{*}{ Clay loam } & & & & & \\
\hline & & & & 1 & & & \\
\hline & & & & 11 & 2 & & Thin layer of gravel at $28 \mathrm{cmbs}$ \\
\hline & & & & & & & \\
\hline & & & & & & & \\
\hline \multicolumn{8}{|l|}{$S T \# 2$} \\
\hline 1 & $10 Y R 7 / 4$ & Sand & & & & & \\
\hline 2 & \multirow[t]{4}{*}{$10 \mathrm{YR} 3 / 1$} & \multirow[t]{4}{*}{ Clay loam } & & & 1 & & \\
\hline 3 & & & & & & & \\
\hline 4 & & & & & & & \\
\hline 5 & & & & & & & \\
\hline \multicolumn{8}{|l|}{ ST\#3 } \\
\hline 1 & \multirow[t]{4}{*}{ 10YR6/1 } & \multirow[t]{4}{*}{ Gravel } & & & & & \multirow[t]{4}{*}{ Construction fill } \\
\hline 2 & & & & & & & \\
\hline 3 & & & & & & & \\
\hline $\begin{array}{l}4 \\
5\end{array}$ & & & & & & & \\
\hline \multicolumn{8}{|l|}{ STH4 } \\
\hline 1 & \multirow[t]{2}{*}{$10 \mathrm{YR} 6 / 2$} & \multirow[t]{2}{*}{ Gravel } & & & & & \multirow[t]{3}{*}{ Construction fill } \\
\hline 2 & & & & & & & \\
\hline 3 & $10 Y R 7 / 3$ & Gravel & & & & & \\
\hline \multirow{2}{*}{$\begin{array}{r}4 \\
5\end{array}$} & \multirow[t]{2}{*}{$10 \mathrm{YR} 2 / 1$} & \multirow[t]{2}{*}{ Clay loam } & & & 1 & & \\
\hline & & & & & & & \\
\hline \multicolumn{8}{|l|}{ STH5 } \\
\hline 1 & $10 \mathrm{YR} 6 / 3$ & Gravel & & & 1 & & Construction fill \\
\hline 2 & \multirow{4}{*}{$10 \mathrm{YR} 3 / 1$} & Clay loam & & & 2 & & \\
\hline 3 & & & & & 3 & & \\
\hline 4 & & & 1 & & 9 & & \\
\hline 5 & & & & & & & \\
\hline ST\#6 & & & & & & & \\
\hline 1 & 10YR6/4 & Sandy loam & & 1 & 6 & 4 & Construction fill \\
\hline 2 & 10YR3/1 & Clay loam & & & 14 & 2 & \\
\hline 3 & & & & & 1 & & \\
\hline 4 & & & & & 1 & & \\
\hline 5 & & & & & 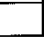 & & \\
\hline ST\#7 & & & & & & & \\
\hline 1 & $10 \mathrm{YR} 3 / 2$ & Clay loam with gravel & & 1 & 23 & 6 & Mixed with construction fill; three FCR \\
\hline 2 & & & & & 27 & 7 & 1 FCR \\
\hline 3 & $10 \mathrm{YR} 3 / 2$ & Clay loam & & & 3 & & \\
\hline 4 & $10 Y R 3 / 2$ & Sandy clay & & & 2 & 1 & \\
\hline 5 & & & & & 1 & & \\
\hline
\end{tabular}


Table 12. Artifacts Recovered in 1998 Shovel Tests continued...

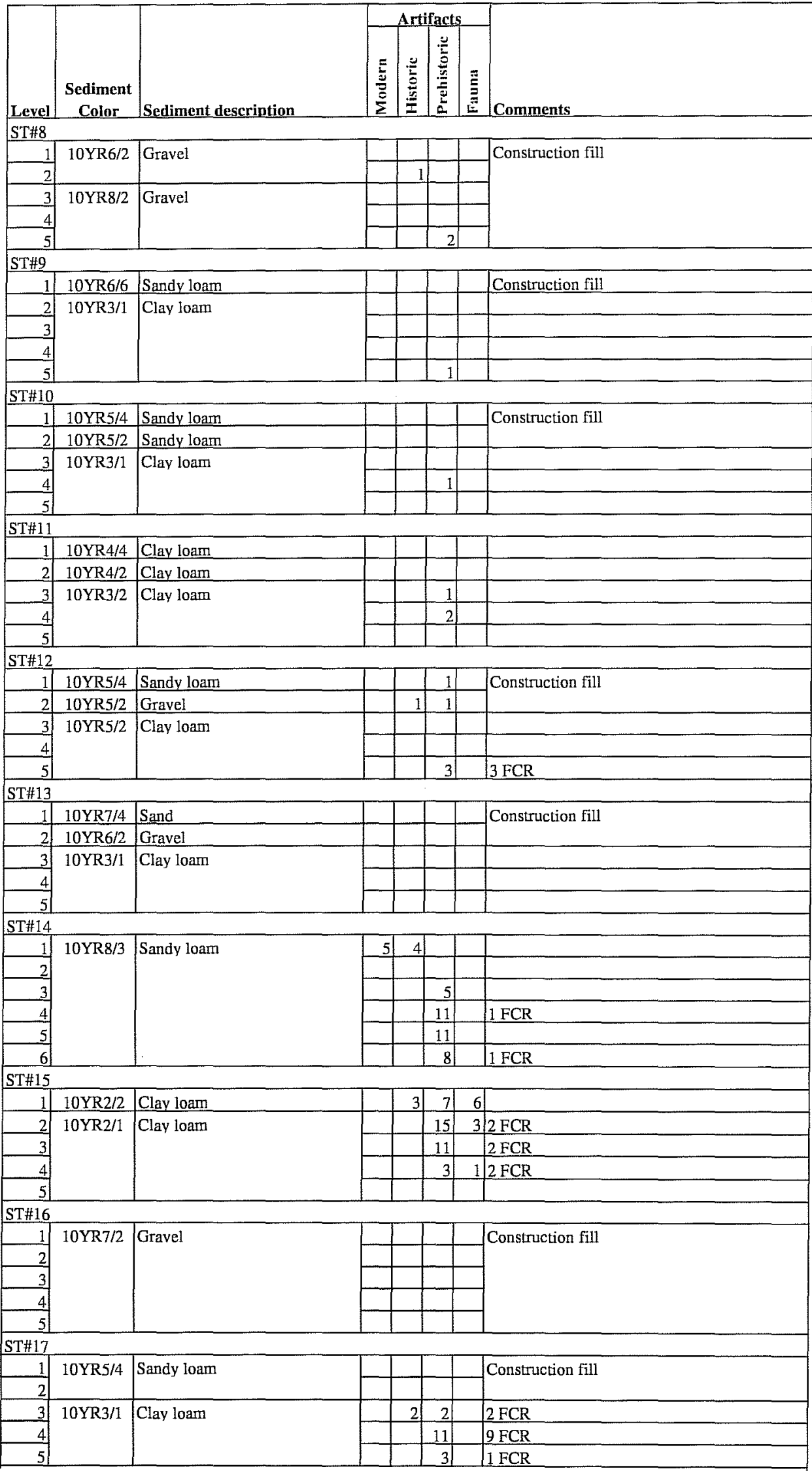


Table 12. Artifacts Recovered in 1998 Shovel Tests continued...

\begin{tabular}{|c|c|c|c|c|c|c|c|}
\hline Level & $\begin{array}{c}\text { Sediment } \\
\text { Color }\end{array}$ & Sediment descrintion & $\frac{E}{E}$ & 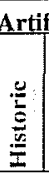 & 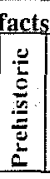 & 吾 & Comments \\
\hline \multicolumn{8}{|c|}{ ST\#19 } \\
\hline 1 & \multirow{3}{*}{10 YR6/6 } & \multirow{3}{*}{ Clay loam } & & & & & \\
\hline 2 & & & & & & & \\
\hline 3. & & & & & 2 & & $1 \mathrm{FCR}$ \\
\hline 4 & \multirow{2}{*}{ 10YR3/1 } & \multirow[t]{2}{*}{ Clay loam } & & & & & \\
\hline 5 & & & & & 1) & & \\
\hline \multicolumn{8}{|l|}{ ST\#20 } \\
\hline & \multirow[t]{4}{*}{$10 Y R 5 / 2$} & \multirow[t]{4}{*}{ Sand } & & & & & \multirow[t]{4}{*}{ Construction fill } \\
\hline 2 & & & 1 & & & & \\
\hline 3 & & & & & & & \\
\hline-4 & & & & & & & \\
\hline \multicolumn{8}{|c|}{ STH21 } \\
\hline & 10YR6/6 & Clay loam & & & & & Disturbed, redeposited \\
\hline 2 & $10 Y R 3 / 1$ & Gravels & & & & & Construction fill \\
\hline 3 & \multirow[t]{3}{*}{$10 \mathrm{YR} 3 / 1$} & Clay loam & & & & 1 & \\
\hline 4 & & & & & & & \\
\hline 5 & & & & & & & \\
\hline ST\#22 & & & & & & & \\
\hline 1 & $10 \mathrm{YR} 6 / 4$ & Sandy loam & 1 & & & & Construction fill \\
\hline 2 & 10YR4/1 & Clay loam & & & & & \\
\hline 3 & & & & & & & \\
\hline 4 & & & & & & & \\
\hline 5 & & & & & & & \\
\hline $\mathrm{STH23}$ & & & & & & & \\
\hline 1 & $10 \mathrm{YR} 3 / 2$ & Clay loam & & & & & \\
\hline 2 & & & & & & & \\
\hline 3 & & & & & & & \\
\hline 4 & $10 \mathrm{YR} 3 / 1$ & Clay loam & & & 2 & & 1 FCR \\
\hline 5 & & & & & & & \\
\hline STH24 & & & & & & & \\
\hline 1 & $10 \mathrm{YR} 4 / 1$ & Clay loam & & & & & Disturbed, redeposited(?) \\
\hline 2 & $10 \mathrm{YR} 8 / 2$ & Gravel & & & & & Construction fill \\
\hline 3 & $10 \mathrm{YR} 7 / 2$ & Gravel & & & & & Construction fill \\
\hline 4 & $10 \mathrm{YR} 5 / 1$ & Clay loam & & & & & \\
\hline 5 & & & & & & & \\
\hline STH25 & & & & & & & \\
\hline 1 & 10YR5/4 & Clay loam & & & & & \\
\hline 2 & $10 \mathrm{YR} 4 / 4$ & Clay loam & 1 & & 1 & & \\
\hline 3 & & & 1 & & 1 & & \\
\hline 4 & $10 Y R 3 / 2$ & Clay loam & & & & & \\
\hline 5 & & & & 3 & 2 & & \\
\hline STH26 & & & & & & & \\
\hline 1 & $7.5 \mathrm{YR} 5 / 6$ & Sandy clay & & & & & \\
\hline 2 & 10YR4/1 & Clay loam & & & & & \\
\hline 3 & & & & & 2 & & \\
\hline 4 & & & & & 4 & & \\
\hline 5 & & & & & 1 & & \\
\hline ST\#27 & & & & & & & \\
\hline 1 & $10 \mathrm{YR} 5 / 6$ & Clay & & & & & Construction fill \\
\hline 2 & $10 Y R 5 / 6$ & Sandy clay & & & & & \\
\hline 3 & $10 \mathrm{YR} 5 / 2$ & Sandy loam & & & & & \\
\hline 4 & 10YR6/3 & Sandy loam & & & & & \\
\hline 5 & 10YR5/3 & Sandy loam & & & & & \\
\hline ST\#28 & & & & & & & \\
\hline 1 & $7.5 \mathrm{YR} 6 / 6$ & Sandy clay & & & & & Construction fill \\
\hline 2 & & & & & & & \\
\hline 3. & & & & & & & \\
\hline 4 & 7.5 YR6/6 & Sand & & & & & \\
\hline
\end{tabular}


Table 12. Artifacts Recovered in 1998 Shovel Tests continued...

\begin{tabular}{|c|c|c|c|c|c|c|c|}
\hline Level & $\begin{array}{c}\text { Sediment } \\
\text { Color }\end{array}$ & Sediment description & $\frac{E}{\Sigma}$ & 莫 & facts & 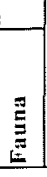 & Comments \\
\hline \multicolumn{8}{|c|}{ (1) } \\
\hline & & Gravel mixed with clay & & & & & Construction fill \\
\hline 2 & \multirow{4}{*}{10 YR $3 / 1$} & \multirow{4}{*}{ Clay loam } & & & & & \\
\hline & & & & & & & \\
\hline 4 & & & & 1. & 1 & & \\
\hline 5 & & & 2 & & 1 & & \\
\hline \multicolumn{8}{|l|}{ ST\#30 } \\
\hline 1 & $10 \mathrm{YR} 4 / 1$ & Clay loam & 1 & & & & \\
\hline 2 & \multirow{4}{*}{ 10YR3/1 } & \multirow[t]{4}{*}{ Clay loam } & 1 & & & & \\
\hline 3 & & & & & 1 & & \\
\hline 4 & & & & & 1. & & \\
\hline 5 & & & & & 1 & & \\
\hline \multicolumn{8}{|l|}{ ST\#31 } \\
\hline 1 & \multirow[t]{5}{*}{$10 Y R 3 / 2$} & \multirow[t]{5}{*}{ Clay loam } & & & & & \multirow[t]{5}{*}{ Disturbed throughout } \\
\hline 2 & & & & 1. & 3. & & \\
\hline 3 & & & & 1 & & & \\
\hline 4 & & & & 1 & 1 & & \\
\hline 5 & & & & & 1 & & \\
\hline \multicolumn{8}{|l|}{ ST\#32 } \\
\hline 1 & $10 Y R 4 / 1$ & Clay loam & 40 & & & 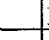 & Disturbed, redeposited \\
\hline 2 & \multirow[t]{2}{*}{ 10YR6/2 } & Gravels & 6 & & & - & Construction fill \\
\hline 3 & & & & & & & \\
\hline 4 & 10YR4/1 & Clay loam & 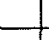 & & & 1 & \\
\hline 5 & & & 2 & & & 3. & \\
\hline 6 & $10 \mathrm{YR} 3 / 1$ & Clay loam & & & & & \\
\hline $\mathrm{STH} 33$ & & & & & & & \\
\hline 1 & $10 \mathrm{YR} 3 / 2$ & Clay loam & 1 & & & & \\
\hline 2 & & & & & 5 & 4 & $1 \mathrm{FCR}$ \\
\hline 3 & & & 1 & & 5 & 20 & $3 \mathrm{FCR}$ \\
\hline 4 & & & & & & & \\
\hline 5 & & & & & & & \\
\hline ST\#34 & & & & & & & \\
\hline 1 & $10 Y R 3 / 1$ & Clay loam & 13 & & 1 & 4 & \\
\hline 2 & $10 Y R 2 / 1$ & Clay loam & & & 15 & 12 & \\
\hline 3 & & & & & 33 & 1 & $1 \mathrm{FCR}$ \\
\hline 4. & & & & & 7 & 3) & \\
\hline 5 & & & 1 & & & 4 & \\
\hline $\mathrm{ST} \# 35$ & & & & & & & \\
\hline 1 & $10 Y R 3 / 2$ & Clay loam & 2. & & & 1. & \\
\hline 2. & & & & 2 & 5 & 2 & \\
\hline 3. & & & & & & & \\
\hline 4 & & & & & & & \\
\hline 5 & & & & & & & \\
\hline ST\#36 & & & & & & & \\
\hline 1 & $7.5 \mathrm{YR} 4 / 4$ & Clay loam & 1 & & 1 & & \\
\hline 2 & 10YR3/1 & Clay loam & 1 & 1 & 5 & 2 & \\
\hline 3 & & & 1 & & 13 & 2. & $1 \mathrm{FCR}$ \\
\hline 4 & & & & 2 & 1 & & \\
\hline 5 & $10 \mathrm{YR} 2 / 1$ & Clay loam & & & 7 & & \\
\hline ST\#37 & & & & & & & \\
\hline 1 & $10 \times R 3 / 2$ & Gravels & 1 & & 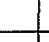 & & Construction fill \\
\hline 2 & 10YR3/1 & Clay loam & 1 & & 5 & 2 & \\
\hline 3 & & & & & 37 & 1 & $1 \mathrm{FCR}$ \\
\hline 4. & & & & & 24 & 8 & $2 \mathrm{FCR}$ \\
\hline 5 & & & & & 33 & & 1 FCR \\
\hline 61 & & & & & 17 & & $1 \mathrm{FCR}$ \\
\hline
\end{tabular}


Table 12. Artifacts Recovered in 1998 Shovel Tests continued...

\begin{tabular}{|c|c|c|c|c|c|c|c|}
\hline \multirow[b]{2}{*}{ Level } & \multirow[b]{2}{*}{$\begin{array}{c}\text { Sediment } \\
\text { Color }\end{array}$} & \multirow[b]{2}{*}{ Sediment description } & \multicolumn{4}{|c|}{ Artifacts } & \multirow[b]{2}{*}{ Comments } \\
\hline & & & $\frac{\Xi}{\Sigma}$ & 莣 & 竞 & 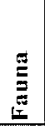 & \\
\hline \multicolumn{8}{|c|}{ ST\#38 } \\
\hline 1 & \multirow{2}{*}{$10 \mathrm{YR} 2 / 1$} & \multirow[t]{2}{*}{ Clay loam } & 3 & & 1 & & \\
\hline 2 & & & & & & & \\
\hline \multirow{3}{*}{\begin{tabular}{|l|}
3 \\
4 \\
5 \\
\end{tabular}} & \multirow[t]{3}{*}{ 10YR3/1 } & \multirow[t]{3}{*}{ Clay loan } & & & & 2 & \\
\hline & & & & & 1 & & \\
\hline & & & 1] & & 18 & & \\
\hline \multicolumn{8}{|l|}{ ST\#39 } \\
\hline 1 & \multirow[t]{2}{*}{$10 \mathrm{YR} 3 / 2$} & \multirow[t]{2}{*}{ Clay loam } & 1 & 6 & 1 & & \\
\hline 2 & & & & & 1 & 2 & \\
\hline \multirow{3}{*}{$\frac{3}{4}$} & \multirow[t]{3}{*}{$10 \mathrm{YR} 3 / 3$} & \multirow[t]{3}{*}{ Clay loam } & & 1 & 2 & 1 & \\
\hline & & & & & & & \\
\hline & & & & & & & \\
\hline \multicolumn{8}{|c|}{ STH40 } \\
\hline $\mathrm{l}$ & \multirow{5}{*}{$10 \mathrm{YR} 3 / 2$} & \multirow[t]{5}{*}{ Clay loam } & & & 33 & \multicolumn{2}{|c|}{\begin{tabular}{l|l|l|}
5 & $2 \mathrm{FCR}$ \\
\end{tabular}} \\
\hline 2 & & & & & 43 & 10 & \\
\hline 3 & & & & & 30 & 6 & \\
\hline 4 & & & & & 2 & & \\
\hline 5 & & & & & 1 & 2 & \\
\hline
\end{tabular}




\section{Test Unit Excavations}

Five 1-x-2-m test units were excavated during the current project. The stratigraphy, artifact counts (Table 13), and features encountered in each unit will be described individually. An analysis of the lithic material recovered from each unit is discussed in the next section, followed by description of significant historic artifacts.

Table 13. Artifacts Recovered in Test Units

\begin{tabular}{|c|c|c|c|c|c|c|c|}
\hline \multirow{2}{*}{$\frac{\text { Level }}{\text { TU \#1 }}$} & $\begin{array}{c}\text { Sediment } \\
\text { Color }\end{array}$ & Sediment description & $\frac{E}{\mathrm{~J}}$ & 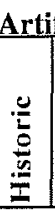 & $\begin{array}{l}\text { ifacts } \\
\frac{2}{2} \\
\frac{2}{2} \\
\frac{2}{2} \\
\frac{2}{2} \\
\frac{2}{2}\end{array}$ & $\underset{E}{E}$ & Comments \\
\hline & \multirow{6}{*}{ 10YR3/1 } & & & & & & \\
\hline 1 & & \multirow[t]{2}{*}{ Clay loam, compacted } & 6 & 45 & 210 & 69 & 14 FCR, 3 bone-tempered-sherds \\
\hline 2 & & & & 23 & 320 & 143 & $20 \mathrm{FCR}, 2$ bone-tempered sherds \\
\hline 3 & & \multirow[t]{3}{*}{ Clay loam } & & 1 & 376 & 12 & $10 \mathrm{FCR}$ \\
\hline 4 & & & & & 832 & 68 & $4 \mathrm{FCR}$ \\
\hline 5 & & & & & 197 & 14 & $6 \mathrm{FCR}$ \\
\hline \multicolumn{8}{|l|}{ TU \#2 } \\
\hline 1 & \multirow[t]{5}{*}{ 10YR3/1 } & \multirow[t]{2}{*}{ Clay loam, compacted } & 10 & 55 & 156 & 55 & $6 \mathrm{FCR}, 1$ dart point fragment \\
\hline 2 & & & & 3 & 685 & 144 & $\begin{array}{l}27 \text { FCR, } 1 \text { dart point base, } 1 \text { distal arrow point } \\
\text { fragement, } 1 \text { bullet }\end{array}$ \\
\hline 3 & & \multirow[t]{3}{*}{ Clay loam } & & & 257 & 62 & 1 metate fragment \\
\hline 4 & & & & & 52 & 6 & \\
\hline 5 & & & & & 15 & & 1 FCR \\
\hline \multicolumn{8}{|l|}{ TU \#3 } \\
\hline 1 & \multirow[t]{2}{*}{ 10YR3/1 } & \multirow[t]{2}{*}{ Clay loam, compacted } & 194 & 4 & 56 & 14 & \multirow{2}{*}{$\begin{array}{l}6 \text { FCR } \\
3 \text { FCR, 38bone-tempered sherds }\end{array}$} \\
\hline 2 & & & 47 & 2 & 296 & 125 & \\
\hline \multicolumn{8}{|c|}{ 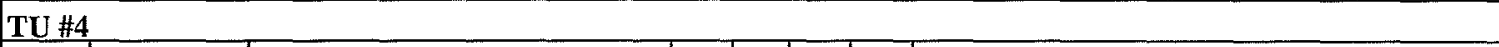 } \\
\hline 1 & $10 \mathrm{YR} 7 / 4$ & Sandy loam & & & & & \multirow[t]{2}{*}{ Construction fill } \\
\hline 2 & 10YR6/2 & Gravel & & 3. & & & \\
\hline 3 & $10 Y R 3 / 1$ & Clay loam, compacted & & & & & \\
\hline 4 & $10 \mathrm{YR} 3 / 1$ & \multirow{2}{*}{$\begin{array}{l}\text { Clay loam } \\
\text { Clay loam }\end{array}$} & 5 & 2 & 28 & & \\
\hline 5 & $10 \mathrm{YR} 3 / 2$ & & 2 & & 17 & 2 & $4 \mathrm{FCR}$ \\
\hline \multicolumn{8}{|c|}{ TU \#5 } \\
\hline 1 & 10YR5/4 & Clay loam & & & & & Construction fill \\
\hline 2 & \multirow{7}{*}{ 10YR3/1 } & \multirow[t]{2}{*}{ Clay loam, compacted } & 1 & 18 & 168 & 42 & \\
\hline 3 & & & & & 6 & 31 & $1 \mathrm{FCR}$ \\
\hline 4 & & \multirow[t]{5}{*}{ Clay loam } & & 1 & 19 & 1 & \\
\hline 5 & & & & & 19 & 1 & \\
\hline 6 & & & & & 10 & & \\
\hline 7 & & & & & & & \\
\hline 8 & & & & & 1. & & \\
\hline 9 & 10YR6/2 & Clay & & & & & \\
\hline 10 & $10 \mathrm{YR} 4 / 2$ & Clay loam & & & 2 & & \\
\hline
\end{tabular}




\section{Test Unit 1}

The matrix in each excavated level of TU 1 was a very dark gray clay loam, although the upper $20 \mathrm{~cm}$ were markedly more compact (Figure 30 ). Two lenses of calcium carbonate and crushed snail shells were encountered at approximately $15-18 \mathrm{~cm}$ bs and at $35-$ $40 \mathrm{~cm}$ bs. Although no features were encountered in TU 1, very high artifact densities were noted in all excavation levels, particularly in Level $4(4,160$ artifacts $/ \mathrm{m}^{3}$ ). Aboriginal ceramic sherds from the Late Prehistoric or Colonial periods were found in Levels 1 and 2.

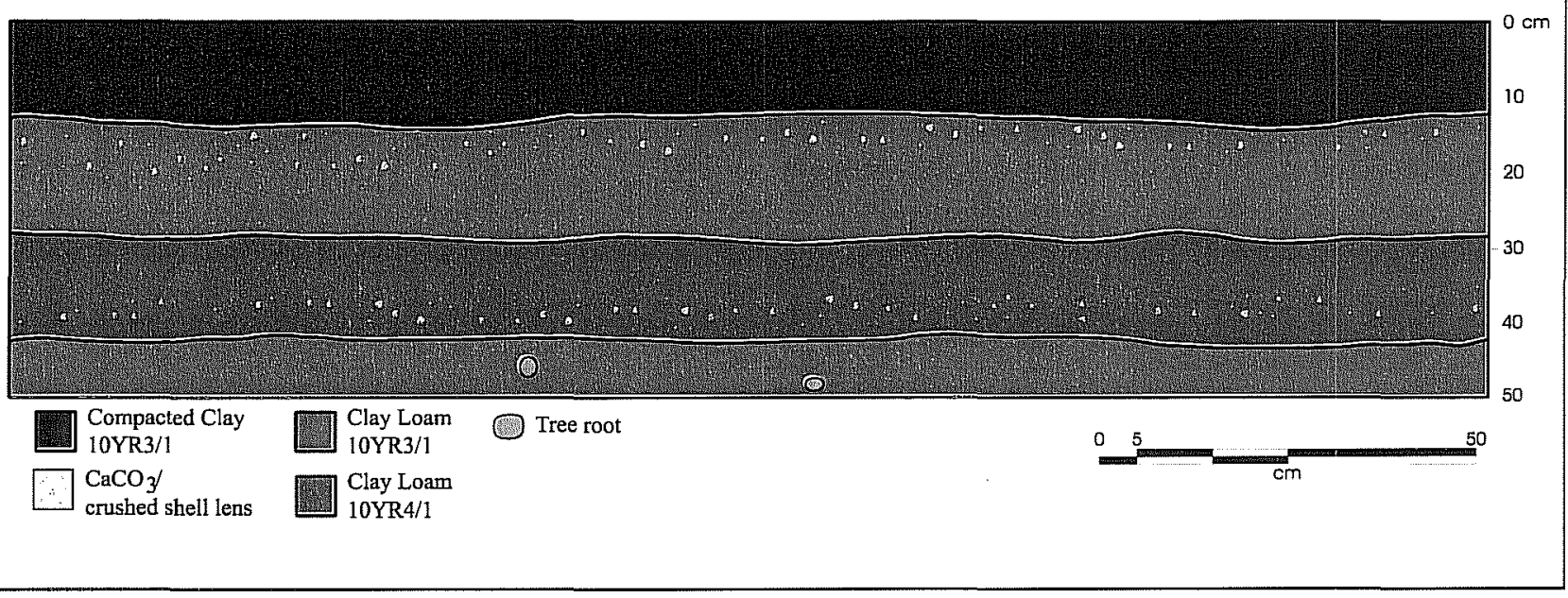

Figure 30. Profile of east wall of Test Unit 1.

\section{Test Unit 2}

The five excavated levels of TU 2 contained a very dark gray clay loam (Figure 31). The upper $25 \mathrm{~cm}$, however, were very compact. A lens of crushed snail shells was noted at $15-22 \mathrm{~cm}$ bs. This unit contained far fewer artifacts than TU 1, but high artifact and faunal densities were present in Level 2. This level contained a broken Perdiz arrow point (Table 13). A single metate fragment was recovered from Level 3 (Table 13). Artifact counts dropped dramatically in Levels 4 and 5 . No features were designated in TU 2, but burned rock was concentrated in the west half of the unit in Level 2. 
Figure 31. Profile of east wall of Test Unit 2.

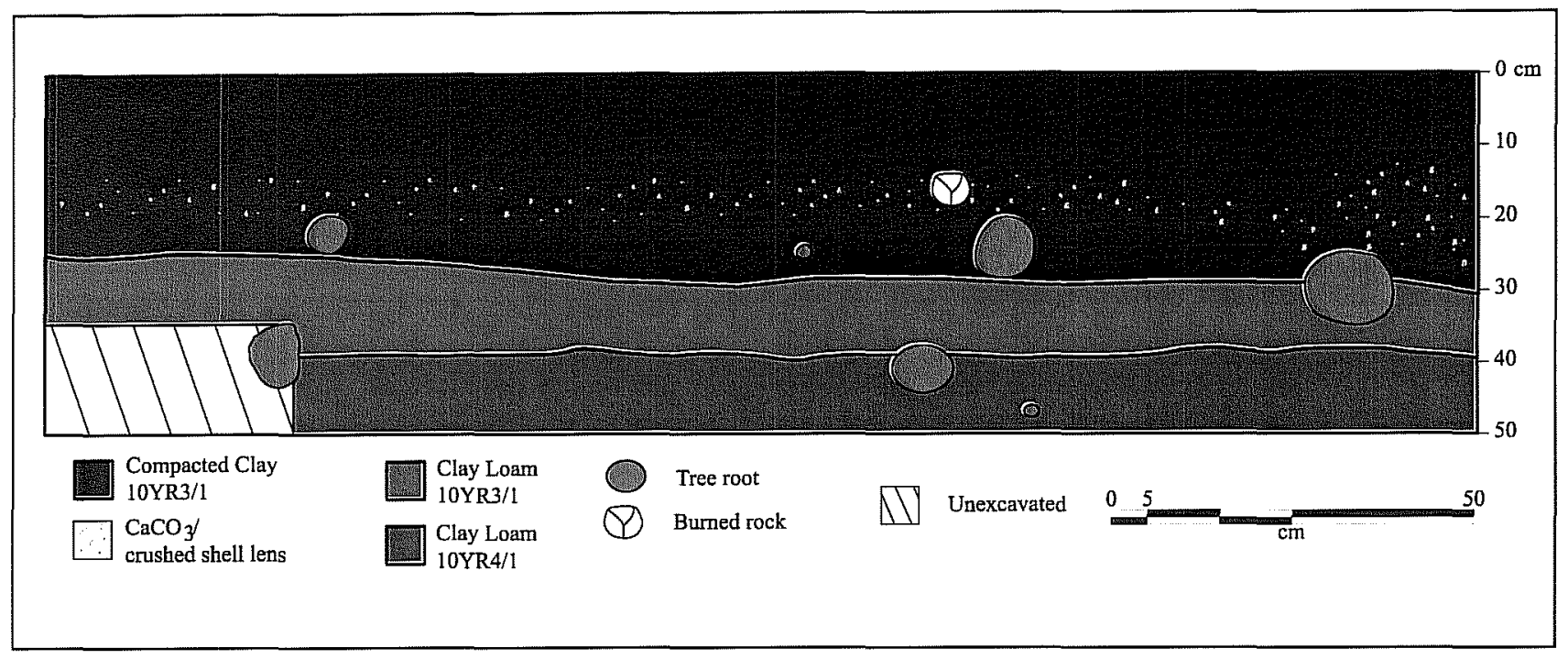

\section{Test Unit 3}

In Level 1, reddish sandy loam extended to $4 \mathrm{~cm}$ bs in the south half of TU 3 . The rest of the level contained extremely compact clay loam exhibiting conchoidal fracturing. This same matrix was encountered in Level 2 . The unit was abandoned before Level 2 was completed because a large tree stump was encountered in the northeast corner of the unit in Level 2. This stump was apparently from a large pecan tree that had been cut down. Level 2 contained a mix of modern, historic, prehistoric, and faunal materials, including $\mathbf{3 8}$ bone-tempered ceramic sherds.

Figure 32. Profile of east wall of Test Unit 4.

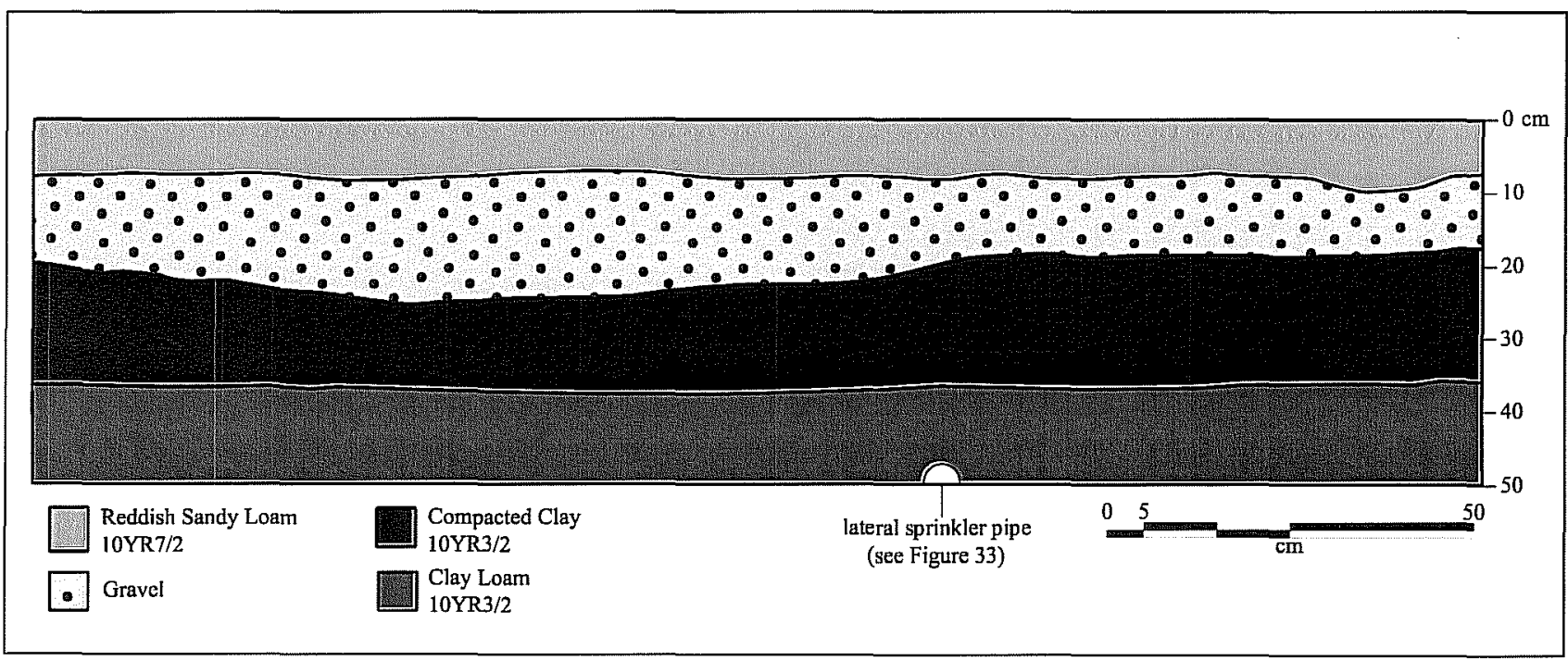




\section{Test Unit 4}

TU 4 encountered highly disturbed deposits (Figure 32). The upper $9 \mathrm{~cm}$ of the unit was comprised of reddish sandy loam construction fill. This overlay a 12$18 \mathrm{~cm}$ thick layer of gravel. Beneath the gravel layer, excavators encountered a machine compacted zone of clay loam ranging from 10 to $15 \mathrm{~cm}$ thick. The bottom $15 \mathrm{~cm}$ of the unit contained a very dark gray clay loam. Few artifacts were recovered from the unit, and all of these were from mixed contexts (see Table 13).

An intrusive feature (designated Feature 1) was documented in TU 4. Feature 1 consisted of a buried sprinkler head, its concrete collar, and associated water pipe (Figure 33). The top of the sprinkler assembly was encountered at $25 \mathrm{~cm}$ bd directly beneath the layer of gravel fill. This disturbance predates the impact to the park that was being assessed by this testing project.
The south $1-\mathrm{m}$ section of TU 5 was excavated to $1 \mathrm{~m}$ deep (Figure 34). The upper $10 \mathrm{~cm}$ consisted of the reddish sandy loam construction fill. This covered a $2-\mathrm{cm}$ thick layer of gravel mixed with clay loam. Between 12 and $30 \mathrm{~cm} \mathrm{bs}$, the matrix was a moderately compacted clay loam. At approximately $30 \mathrm{~cm}$ bs the degree of compaction diminished. The clay loam/clay matrix continued to the bottom of the unit with $\mathrm{CaCO}^{3}$ precipitates increasing in size and frequency from 80 to $100 \mathrm{~cm}$ bs.

No features were encountered in TU 5, and the artifact frequencies were generally low.

The greatest amount of prehistoric and faunal material was found in Level 2, mixed with 19 modern or historic artifacts.

Figure 33. Photograph of Test Unit 4, showing recent fill and sprinkler system components. Looking west.

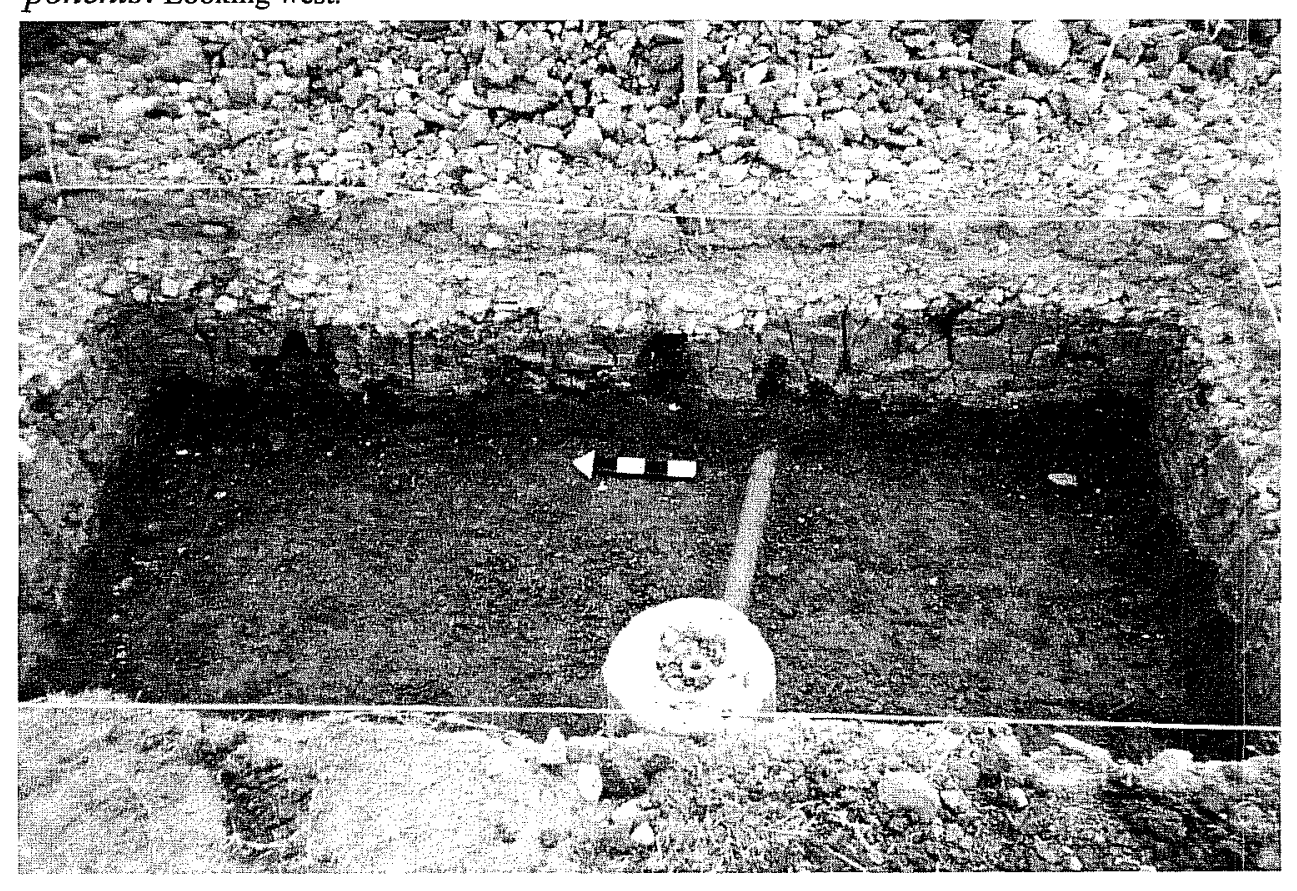


Figure 34. Profile of east wall of Test Unit 5.

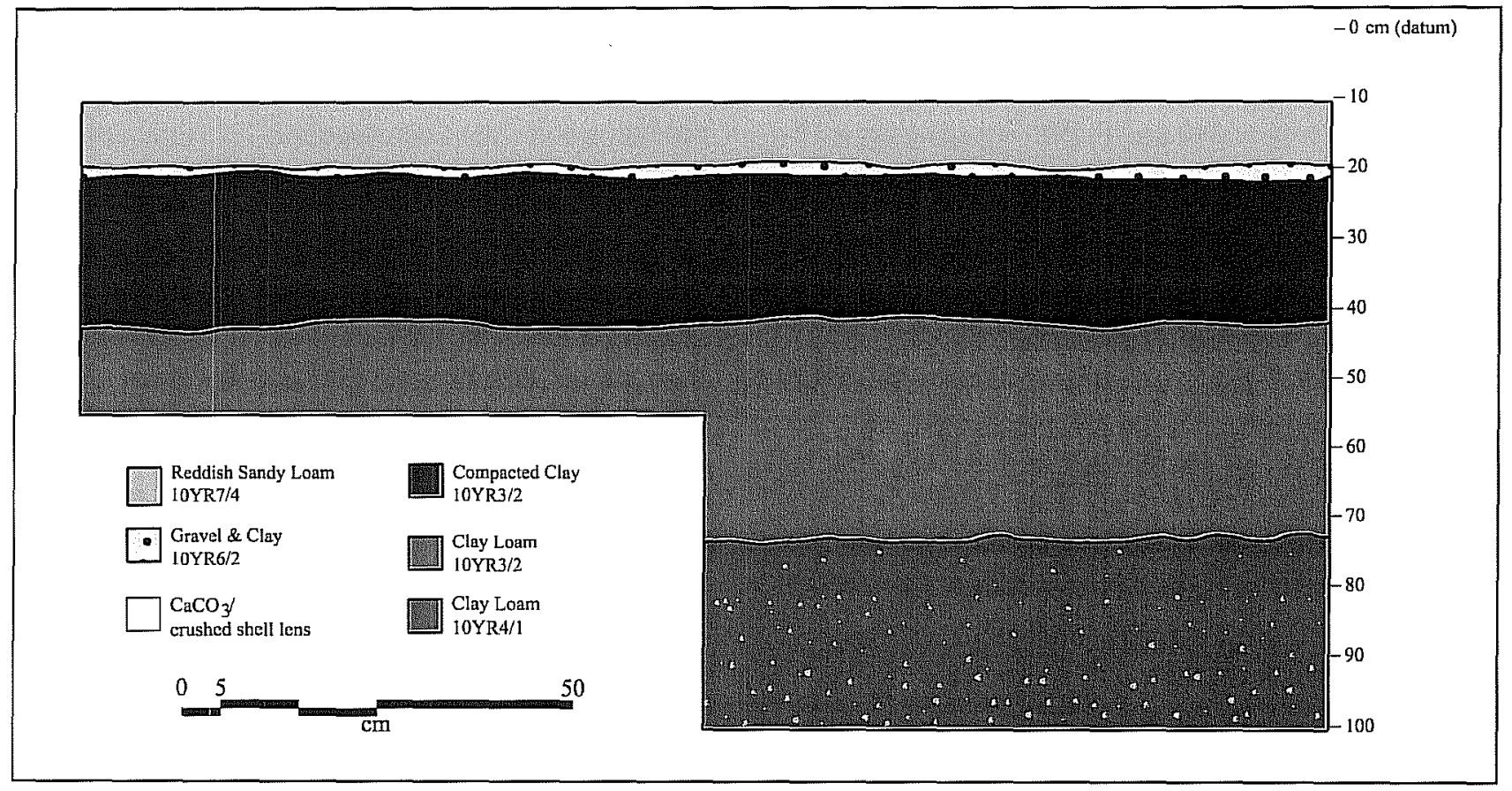

\section{Summary}

Machine-compacted clay loam was encountered in each of the five test units. The greatest degree of compaction was found in TU 3 . The southern units, including the south half of TU 3, contained construction-related fill in the upper 10-18 cm. TU 4 documented a previous disturbance, a sprinkler head and water pipe probably installed in the 1960s (Clint Mackenzie, personal communication 1998).

Artifact counts decreased from north to south. The greatest concentration of prehistoric material was found in TU 1, Level 4, although very high counts were recorded in TU 2, Level 2. Generally, the upper level of clay loam contained a mixture of historic, modern, and prehistoric debris. No burned rock features were designated, but concentrations of burned rock were found in various levels throughout TUs 1 and 2. 


\section{Mapping Data}

\section{Methods}

To determine if any of the original soil was removed from the disturbed area or whether it was simply compacted, in April 1998 the elevations of the surface level of each shovel test were recorded using a total data station surveying instrument. A contour map of the area was then produced from those data, and compared to one produced in 1996 for SARA by Beaty Saunders Architects, Inc./ Rehler Vaughn and Koon, Inc. (Partial Site Grading Plan, Sheet 11 of 100, February 1996), prior to being impacted by heavy machinery and construction fill (see Figure 35). Potentially problematic in comparing the 1996 map with our map of 1998 is the fact that the 1996 pre-impact contour map was produced with fewer elevation shots and therefore is less accurate.

Although Figure 35 compares the surface elevations in 1998 to the pre-impact contours of 1996, it cannot account for the removal of any clay loam soil that may have been removed and then subsequently overlain with fill to restore the surface to original grade.

The CAR survey crew noted several "bluetops" across the impacted area at the park. These are wooden stakes, commonly set during the final stages of grading, that mark the desired elevation. It is possible that these hubs were set to mark the original ground elevation, presumably the point to which the grading was attempting to restore the impacted area. Therefore the thickness of the fill as determined by each shovel test was subtracted from the 1998 surface elevations and a second contour map showing the top of clay loam was produced and compared to the 1996 map (Figure 36). The top of the clay loam in each shovel test was then compared to the estimated elevation of the pre-impact ground surface. The differences in elevation at each shovel test location were then plotted as a contour map (Figure 37).

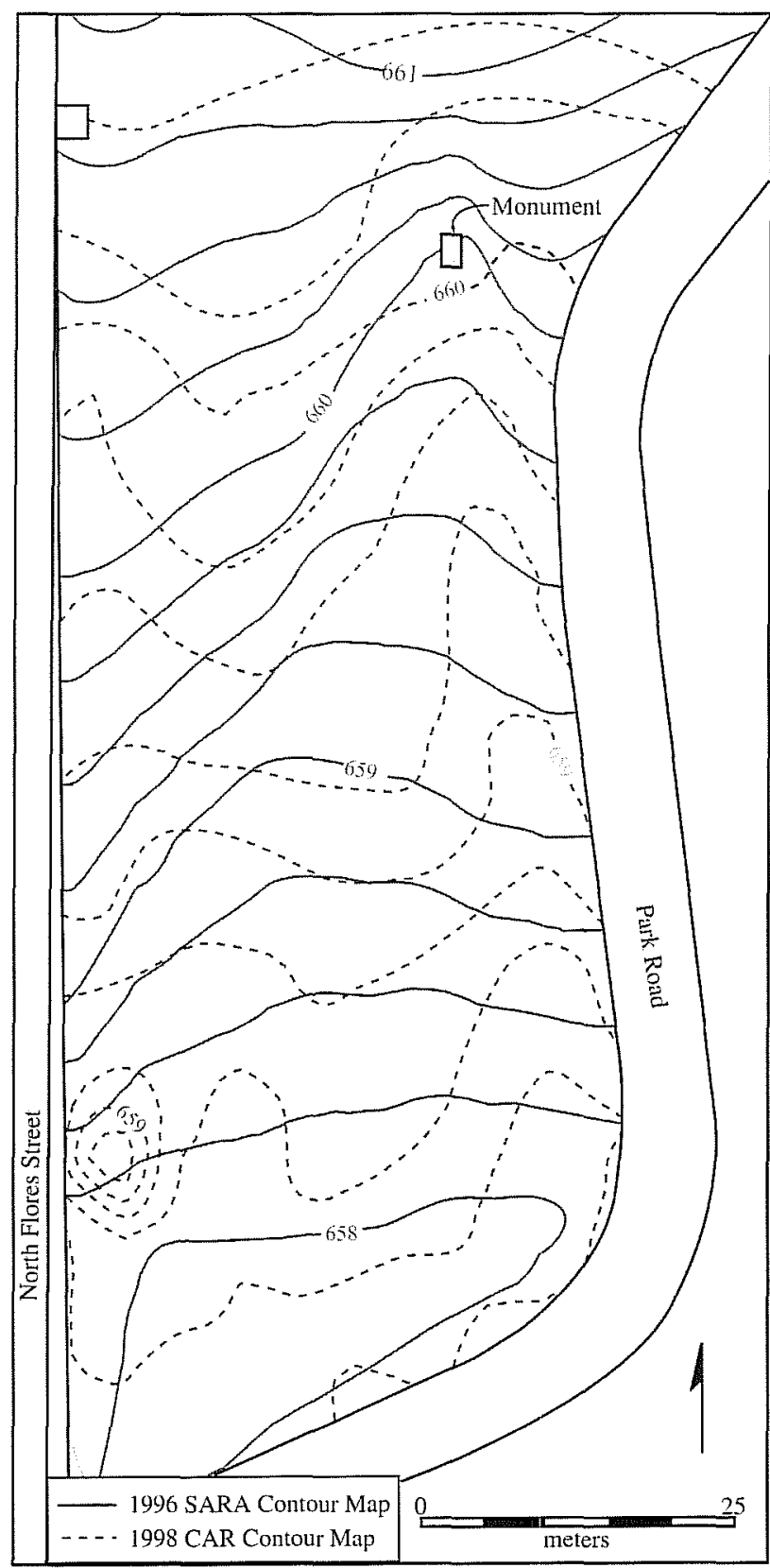

Figure 35. Contour map comparing 1996 pre-impact topography to 1998 post-impact topography. 
Figure 36. Contour map comparing 1996 pre-impact surface with the top of the uncompacted clay loam in April 1998 (post-impact).

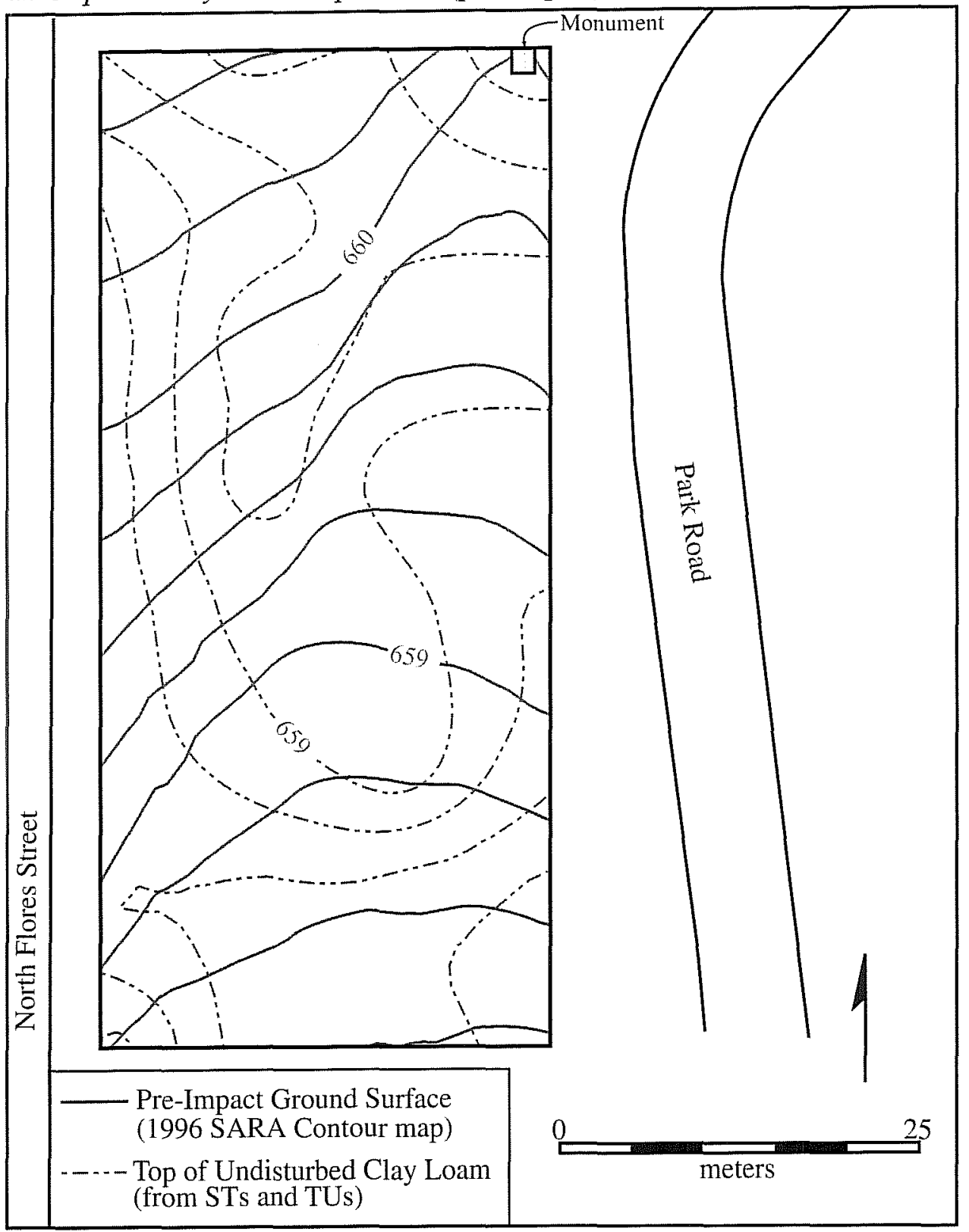




\section{Results and Analysis}

Figure 37 indicates that moderate impact (4.8" to 12 " [12.2 to $30.5 \mathrm{~cm}$ ] difference) occurred in most of the study area. In two sections of the grid the top of the clay loam occurs 12 inches or more below its original elevation. Even allowing for a decrease in elevation through compaction, it is evident that one of the impacts to the project area was the removal of the original clay loam prior to the deposition of the foreign material. Assessing the exact amount of material displaced is impossible, but it is probable that in certain areas 10 inches $(25 \mathrm{~cm})$ or more of soil was removed.

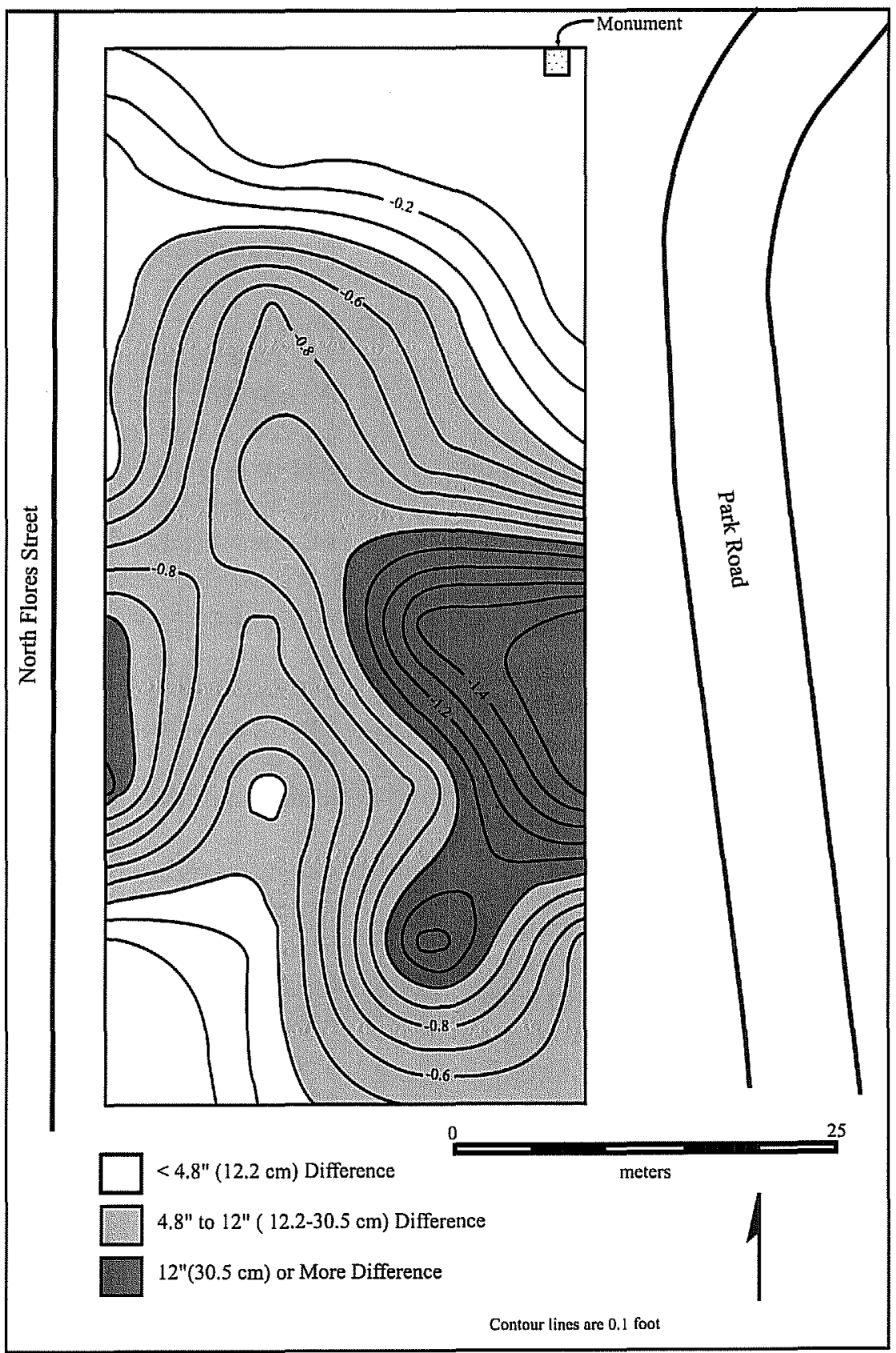

Figure 37. Contour map of differences in clay loam surface in April 1998 (post-impact) compared to surface in 1996 (pre-impact). 


\section{Artifacts}

A total of 5,528 artifacts was recovered during this project, including animal bone and mussel shell. A complete provenienced artifact list is presented in Appendix D.

\section{Lithic Analysis}

\section{Bradley J. Vierra}

This section presents the results of the analysis of 3,581 lithic artifacts recovered from the test units conducted in the southwest corner of San Pedro Park. The assemblage consists of 3,554 pieces of debitage, 9 cores, 18 retouched tools, and a metate fragment, all recovered from five $1-x-2 \mathrm{~m}$ units which were dug to a depth of approximately $50 \mathrm{~cm}$. As the excavation units were situated across the site to identify the nature and extent of possible mechanical disturbance to the archaeological deposits, the lithic analysis will focus on the identification of lithic artifact type and the extent of damage present in the assemblage.

\section{Methods and Definitions}

Six attributes were monitored during the debitage analysis: debitage type, material type, condition, breakage, burning, and damage. Debitage type definitions are provided below. Only two material types were identified during the analysis. These consist of chert and quartz; however, only a single artifact was identified as being made of quartz. Condition is recorded as whole or broken. The breakage attribute identifies whether the break is an old or fresh break. Fresh breaks represented clean surfaces that were lighter in color than the patinated surface of the artifact. Burning is monitored as absent or present, consisting of a crackled surface, pot lids or discoloring of the artifact. Damage refers to any visible damage to the edge or surface of the artifact. It was recorded as absent, fresh damaged edge(s), fresh metal surface scratches, and fresh damaged edge(s) with surface scratches. Only debitage type, material type and burning was monitored for the microdebitage. No attempt was made to identify the condition or presence of damage on the microdebitage.
Cores, retouched tools, and metate fragment are individually described because few of these artifacts are represented. Type definitions are also provided below.

\section{Debitage:}

Are the by-products of core reduction and tool production.

Flakes:

Are pieces of material that have been detached from a core or tool by percussion or pressure, as opposed to angular debris which are pieces that are incidentally broken off during core reduction. These pieces of shatter lack definable flake characteristics, such as a platform, bulb of percussion, ventral/dorsal surfaces, and proximal/distal ends.

\section{Core flakes:}

Are flakes that have been detached from a core. A polythetic set (Clark 1968:36-37) of attributes for core flakes consists of: a single or dihedral platform; a platform angle of greater than 75 degrees; cortex present on dorsal surface; dorsal scars that may be absent, parallel or perpendicular to the platform; a platform approximately equal in width to the flake; a thickness of greater than about $5 \mathrm{~mm}$; a pronounced bulb of percussion; an eraillure scar; and roughly parallel lateral edges. To be classified as a core flake, the flake must exhibit at least five of the nine defining attributes.

\section{Core trimming flakes:}

Are pieces that have been struck at a 90 degrees angle to the major flaking axis of the core, along the edge of the core platform and dorsal flaking surface. They are sometimes referred to as platform renewal or rejuvenation flakes, since they often remove the step fractures that can occur adjacent to the edge of the platform. They may also represent an attempt to change the orientation of the core, by preparing and reorienting a new flaking surface that is perpendicular to the previous major flaking axis. Core trimming flakes are similar to uniface rejuvenation flakes (Highley 1995:482), but none of the latter were identified during this analysis. 


\section{Biface flakes:}

Are flakes that have been detached from a bifacially retouched artifact. A polythetic set of attributes for biface flakes consists of: a multifaceted platform; a lipped platform; a platform angle of less than 75 degrees; an isolated platform; a weak bulb of percussion; cortex absent on dorsal surface; dorsal scars that are roughly parallel to each other and perpendicular to the platform; a thickness of less than 5 $\mathrm{mm}$ that is relatively even from proximal to distal ends; a pronounced ventral curvature; and lateral edges which expand towards the distal end. A flake must exhibit at least five of the nine attributes to be classified as a biface flake.

\section{Uniface flakes:}

Are flakes which have been detached from a unifacially retouched artifact (Jelinek 1966; Shafer 1970). A polythetic set of attributes for uniface flakes consists of: a single faceted platform; a platform angle of greater than 60 degrees; dorsal scars that are parallel to each other and perpendicular to the platform; a single distal scar on the dorsal surface of the flake (sometimes separated by an arris); and marked ventral curvature. A flake must exhibit at least three of the five attributes to be classified as a uniface flake.

\section{Burin spalls:}

Are pieces that have been struck from the edge of a flake, so the resulting scar (or facet) approaches 90 degrees to the plane of the blank from which it was removed.

\section{Pot lids:}

Are hertzian cones produced when siliceous rocks are subjected to heat.

\section{Microdebitage:}

Are debitage with a maximum length equal to or less than $10 \mathrm{~mm}$.
Fragments for which flake type could not be determined were also listed.

\section{Cores:}

Are nodules that have faceted platforms from which specific kinds of flakes are removed.

\section{Retouched tools:}

Are the result of the secondary percussion or pressure flaking of a piece in order to produce a specific tool shape.

\section{Marginally retouched flakes:}

Are flakes $(n=9)$ with retouch that extends over less than one-third of the surface of the artifact (Chapman and Schutt 1977:86). This is non-invasive retouch that is limited to the edge margin, but may be unidirectional or bidirectional.

\section{Unifaces:}

Are artifacts $(n=10)$ which exhibit retouch scars over one-third or more of only one of their surfaces. This type of retouch can be defined as invasive retouch. Unifaces exhibit initial edge retouch and lack a formal overall shape. In contrast, scrapers $(\mathrm{n}=0)$ are specialized forms of unifaces which exhibit secondary edge retouch producing a formal shaped tool with an edge angle between about 60 to 80 degrees.

\section{Bifaces:}

Are artifacts $(n=31)$ which exhibit retouch scars extending over one-third or more of both their opposing surfaces (Chapman and Schutt 1977:93).

Generalized bifaces tend to be ovate or lanceolate in shape, with edge angles between about 30 to 50 degrees.

\section{Projectile points:}

Are specialized forms of bifaces that exhibit hafting modifications that distinguish a stem from the blade

\section{Ground stone tools:}

Are artifacts that exhibit ground and/or abraded surfaces. 
Table 14. Lithic Artifact Types from Test Units

\begin{tabular}{|l|r|r|r|r|r|r|}
\hline \multicolumn{1}{|c|}{ Type } & TU 1 & TU 2 & TU 3 & TU 4 & TU 5 & Total \\
\hline Debitage & 1825 & 1103 & 363 & 40 & 223 & $\mathbf{3 5 5 4}$ \\
\hline Cores & 2 & 4 & 1 & 2 & 0 & $\mathbf{9}$ \\
\hline Retouched & 1 & 0 & 0 & 0 & 1 & $\mathbf{2}$ \\
Flakes & & & & & & \\
\hline Bifaces & 5 & 1 & 0 & 0 & 1 & $\mathbf{7}$ \\
\hline Unifaces & 2 & 0 & 0 & 0 & 0 & $\mathbf{2}$ \\
\hline Proj. Pts. & 1 & 5 & 0 & 0 & 0 & $\mathbf{6}$ \\
\hline Metate & 0 & 1 & 0 & 0 & 0 & $\mathbf{1}$ \\
\hline Total & $\mathbf{1 8 3 6}$ & $\mathbf{1 1 1 4}$ & $\mathbf{3 6 4}$ & $\mathbf{4 2}$ & $\mathbf{2 2 5}$ & $\mathbf{3 5 8 1}$ \\
\hline
\end{tabular}

\section{Results of the Analysis}

Table 14 presents the information on the lithic artifact type by excavation unit. The majority of the artifacts were recovered from TUs 1 and 2, with fewer recovered from TUs $3-5$. TUs 1 and 2 also contain most of the bifaces and unifaces, and all of the projectile points; however, cores are present in four of the five units. The single metate fragment was recovered from TU 2.

\section{Debitage}

As previously noted, all but one of the pieces of the debitage are made of chert. The single exception is a quartz core flake. Table 15 presents the information on debitage type by excavation unit. The majority of the debitage consist of microdebitage (50.8 percent), with fewer undetermined flake fragments, core flakes, biface flakes, angular debris, and other debitage types. The assemblage represents both core reduction and tool production activities, although many of the microdebitage and undetermined flake fragments may also be the by-product of biface manufacturing. Rare debitage types like core trimming flakes, uniface flakes, and burin spalls are present in TUs 1 and 2 with the larger samples sizes. On the other hand, pot lids are present in all the units.

Table 15. Debitage Type by Excavation Unit

\begin{tabular}{|l|r|r|r|r|r|r|}
\hline \multicolumn{1}{|c|}{ Type } & TU 1 & TU 2 & TU 3 & TU 4 & TU 5 & Total \\
\hline Angular debris & 62 & 84 & 42 & 2 & 29 & 219 \\
\hline Core flake & 244 & 115 & 38 & 8 & 41 & 446 \\
\hline Biface flake & 254 & 110 & 24 & 6 & 14 & 408 \\
\hline Uniface flake & 1 & 0 & 0 & 0 & 0 & 1 \\
\hline Core trimming flake & 6 & 1 & 0 & 0 & 0 & 7 \\
\hline Burin spall & 2 & 0 & 0 & 0 & 0 & 2 \\
\hline Pot lid & 10 & 11 & 4 & 1 & 3 & 29 \\
\hline Microdebitage & 1091 & 494 & 167 & 6 & 47 & 1805 \\
\hline Und. flake frag. & 155 & 288 & 88 & 17 & 89 & 637 \\
\hline Total & $\mathbf{1 8 2 5}$ & $\mathbf{1 1 0 3}$ & $\mathbf{3 6 3}$ & $\mathbf{4 0}$ & $\mathbf{2 2 3}$ & $\mathbf{3 5 5 4}$ \\
\hline
\end{tabular}


The majority of the flakes are broken (82.6 percent; $n=1240)$, with fewer whole flakes $(n=261)$. This excludes both microdebitage and pot lids. Of those flakes that are broken, most exhibit old breaks (91.6 percent; $n=1137)$ with some fresh breaks ( $n=103)$. Almost onethird of the debitage assemblage appears to be burned (29.0 percent; $n=1033$ ), with the remainder exhibiting no obvious signs of burning $(n=2521)$. About four percent of the debitage exhibit mechanical damage (3.8 percent; $n=138$ ), consisting of surface scratches $(n=70)$, fresh edge damage $(n=45)$, or both surface scratches and edge damage $(n=23)$. Otherwise, the remaining debitage exhibit no obvious signs of damage $(n=3416)$.

\section{Cores}

Nine cores were recovered from the excavations (see Figure 38a for example from Test Unit 1, Level 4). These consist of four bifacial, two single-platform, and three core fragments. The three broken cores exhibit old breaks. The unbroken cores range in weight from 54.5 to $353.3 \mathrm{gm}$. The single-platform cores were made on cobbles and the bifacial cores on either large flakes or nodules.

\section{Retouched Tools}

Nineteen retouched tools, consisting of retouched flakes, bifaces, unifaces and projectile points, were recovered from the excavations. Two retouched flakes

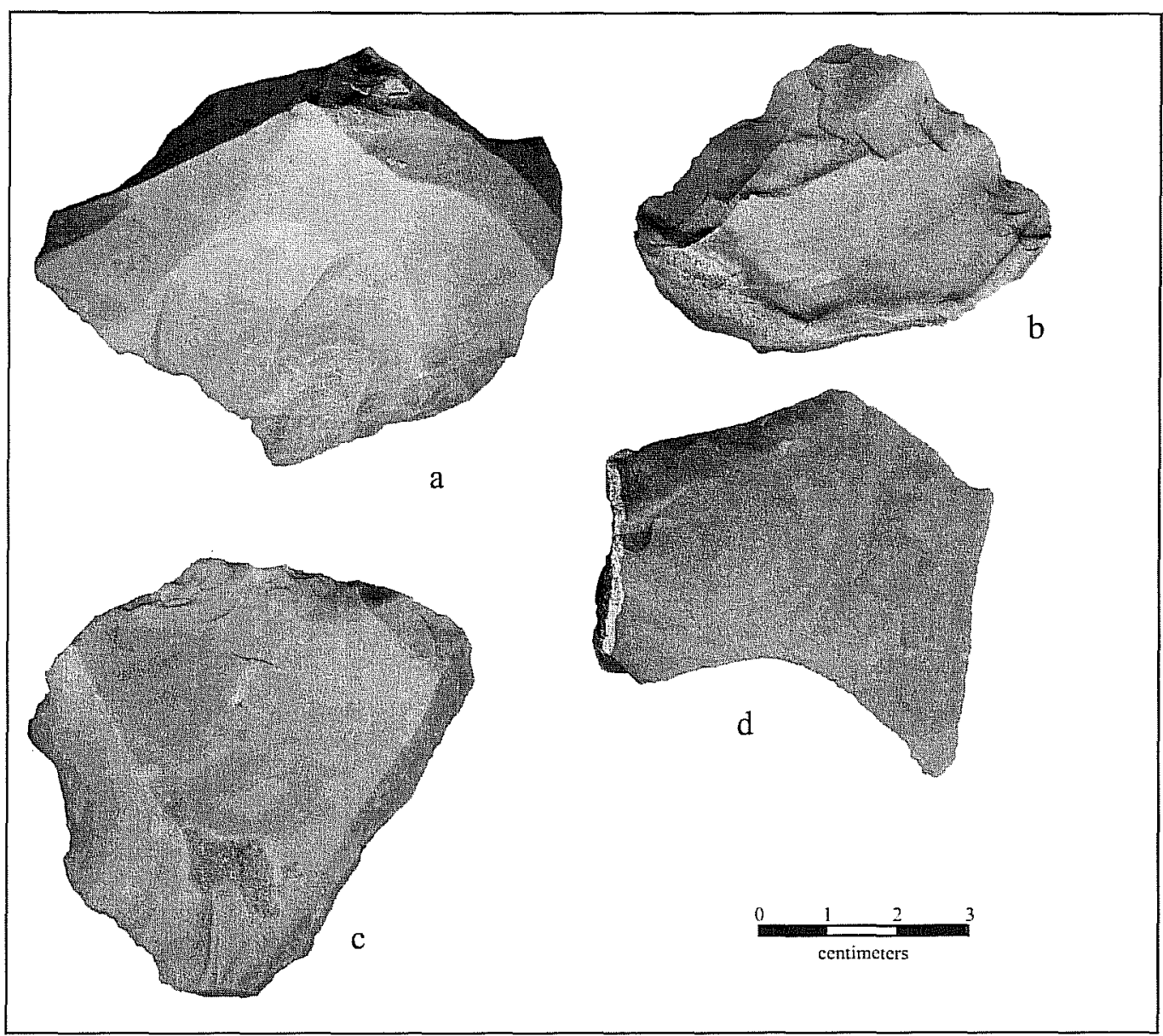

Figure 38. Lithics from Test Units. a) Small core from TU1; b-d) Retouched flakes from TU1, Level 4. 
were manufactured on large flake blanks by bidirectionally retouching a single lateral edge margin (Figure 38b-c). The third was retouched along two edges (Figure 38d).

All nine of the bifaces are broken fragments. Three of these are bases, one a midsection, and five are distal tips. Two base fragments and the midsection exhibit perverse breaks indicating that they were broken during the manufacturing process (Figure 39a-c). Two of the tips also exhibit perverse breaks (example shown in Figure 39d), but the other three are snaps (Figure $39 \mathrm{e}-\mathrm{g})$. Nonetheless, they seem unfinished and may have also been broken during the manufacturing process. One of the biface bases is heavily burned (Figure 39a). There is, however, no evidence of fresh breaks, edge damage or scratches on any of the bifaces.

The unifaces consist of an endscraper and a retouched flake. The endscraper was made on a thick flake blank

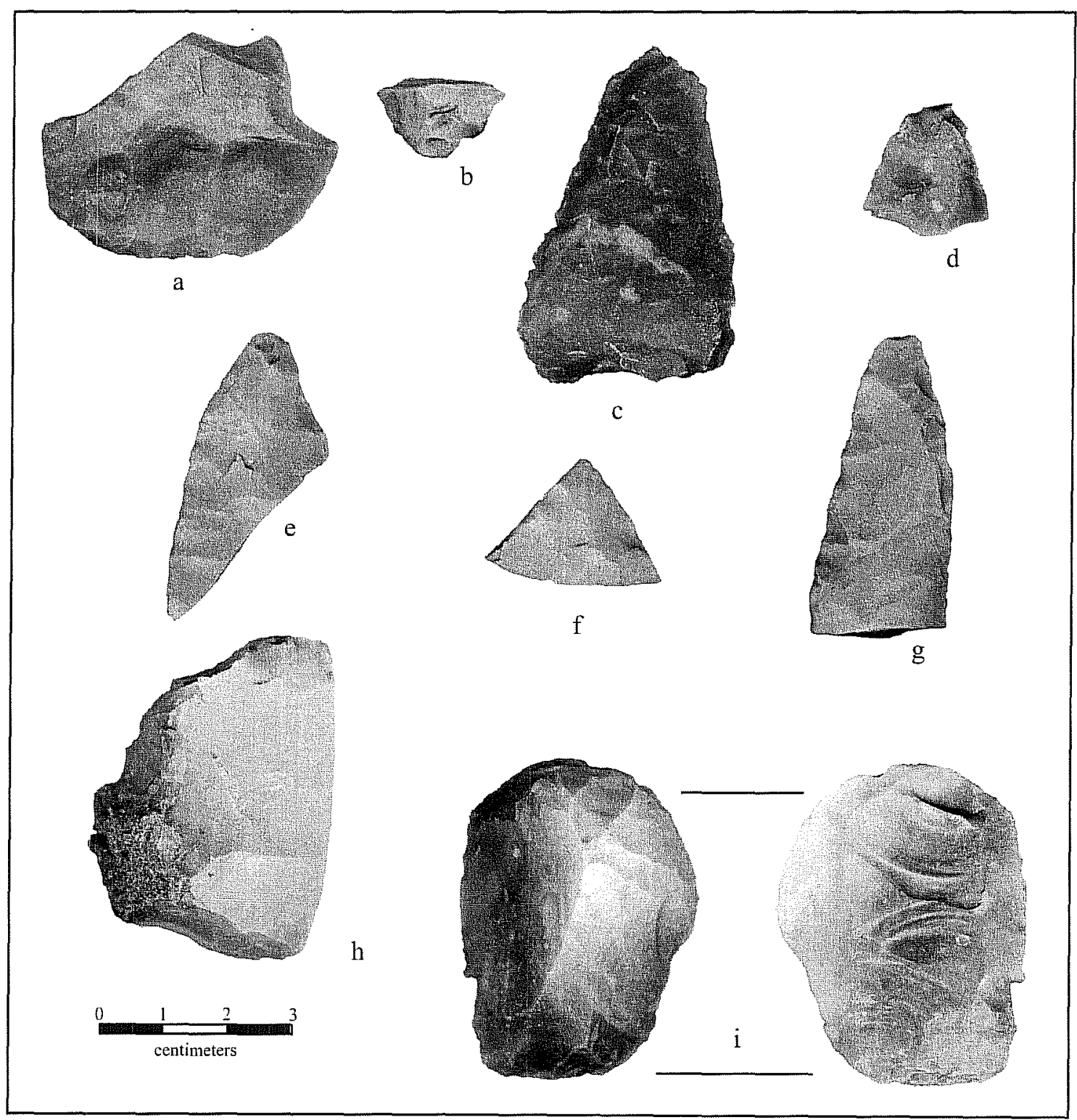

Figure 39. Lithic tool fragments from Test Units. a-b) Biface fragments from TU2, Level 2; c) Biface fragment from TU1, Level 5; d) Biface fragments from TU2, Level 2; e-g) Biface fragments from TU 1, Level 5; h) Uniface from TU 2, Level 1; i) Uniface from TU 1, Level 1, showing both sides. 
Figure 40. Projectile Points from Test Units. a) Point fragment from TU 2, Level 1; b-c) Point fragments from TU 2, Level 2.

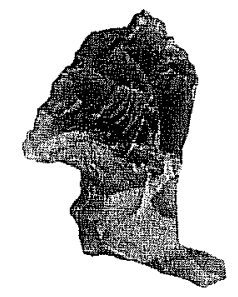

a

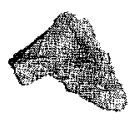

b

(n)

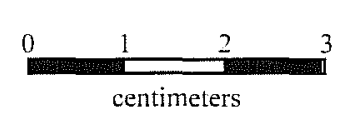

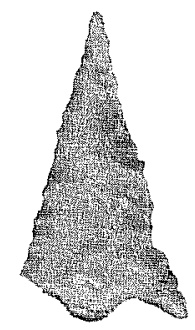

c
(Figure 39h). The opposite end of the scraper was also used as a wedge. It exhibits heavy bidirectional step fracturing, scaling, and is burinated along one edge. The other uniface was also produced on a thick flake blank; however, it consists of a distal fragment with unifacial retouched along two lateral edge margins. This artifact does exhibit metal scratches (Figure 39i).

The four projectile points consist of broken fragments. Two of these are small base fragments (Figure 40a-b) and a midsection that could represent Fairland dart points (e.g., see Turner and Hester 1993:117). That is, they appear to be characterized by an expanding and concave base. The other point is a Perdiz arrow point with a broken base (Figure 40c) (e.g., see Turner and Hester 1993:227). None of the points exhibit any obvious evidence of post-depositional damage. Together these point types represent both Late Archaic and Late Prehistoric occupations.

\section{Ground Stone}

One piece of ground stone was recovered during the excavations. It consists of a sandstone basin metate fragment measuring $160 \times 82 \times 45 \mathrm{~mm}$. It exhibits no evidence of post-depositional mechanical damage.

\section{Lithic Artifact Breakage Patterns}

Numerous debitage appear to represent broken fragments, and although some of the retouched tools are also broken, none exhibit recent breaks. The question is, what processes cause the debitage breakage patterns at the site? Researchers have identified several factors that can affect debitage breakage patterns. These include material type, reduction stage, burning, and various post-depositional processes. Each of these factors will be evaluated in respect to the site debitage assemblage.

\section{Material Type}

The fracture characteristics of a specific material type can vary greatly depending on the property of the material being knapped. Brittle refers to how easily a material breaks, and elasticity to how well it bends before breaking (Whittaker 1994: 13-14). For example, obsidian breaks more easily than chert, which is less brittle and more elastic (e.g., see McBrearty et al. 1998). Another factor can be the presence of inclusions or flaws in the material. Nonetheless, since all but one piece of debitage is made of chert, difference in raw material type is not a significant factor affecting breakage patterns on the site. 


\section{Reduction Stage}

Sullivan and Rozen (1985) suggest that there is a difference in flake breakage rates between core reduction vs. biface production activities. More specifically, the thinner the flake the more likely it is to break during removal. This assumption was experimentally tested by several researchers with contrasting results (e.g., Mauldin and Amick 1989; Prentiss and Romanoski 1989; Tomka 1989). Table 16 presents a contingency table of debitage type by flake condition. There is a significant difference in the condition of core vs. biface flakes (chi-sq $=6.3, \mathrm{df}=1, \mathrm{p}=0.01$ ). Adjusted residuals were therefore calculated to determine which of the contingency table cells was contributing to the significant chi-square value. Adjusted residuals greater than 1.96 or -1.96 are significant at the 0.05 level (Haberman 1973). There appears to be relatively more complete core flakes and broken biface flakes represented in the site assemblage; however, the analysis excluded flake fragments, many of which could be midsections or distal portions of biface thinning flakes. Nonetheless, this pattern corresponds to Sullivan and Rozen's suggestion that biface flakes are more likely to break.

Table 16. Contingency Table of Debitage Type by Flake Condition

\begin{tabular}{|c|r|r|}
\hline \multirow{2}{*}{ Flake Type } & \multicolumn{2}{|c|}{ Flake Condition } \\
\cline { 2 - 3 } & Whole & Fragment \\
\hline \multirow{2}{*}{ Core } & 150 & 295 \\
& $\mathbf{2 . 5}$ & -2.5 \\
\hline \multirow{2}{*}{ Biface } & 105 & 302 \\
& -2.5 & $\mathbf{2 . 5}$ \\
\hline
\end{tabular}

chi-square $=6.3, d f=1, p=0.01$

\section{Burning}

Lithic artifacts may be burned as a by-product of heattreatment or as a result of being discarded into a thermal feature. Experiments show that a lithic artifact subjected to rapid heating or cooling can explode (Purdy 1974). However, proper heat treatment of lithic materials may act to reduce flake breakage during tool production (Patterson 1979). A chi-square analysis of the contingency table of burning by flake condition indicates that there is a significant difference between these categories (chi-sq=25.6, $\mathrm{df}=1, \mathrm{p}=<0.01$; Table 17). That is, there are relatively more broken burned flakes and whole unburned flakes.

Table 17. Burning by Flake Condition

Top value in cell represents artifact count, and bottom value represents adjusted residuals. Significant $(p<0.05)$ positive values are shown in bold.

\begin{tabular}{|c|r|r|}
\hline \multirow{2}{*}{ Burning } & \multicolumn{2}{|c|}{ Flake Condition } \\
\cline { 2 - 3 } & Whole & Fragment \\
\hline \multirow{2}{*}{ Absent } & 229 & 931 \\
& $\mathbf{5 . 1}$ & -5.1 \\
\hline \multirow{2}{*}{ Present } & 26 & 305 \\
& -5.1 & $\mathbf{5 . 1}$ \\
\hline
\end{tabular}

chi-square $=25.6, \mathrm{df}=1, \mathrm{p}=<0$.

\section{Post-Depositional Processes}

Several archaeological studies have focused their attention on the affects of post-depositional processes on artifact assemblage condition and distribution. These have primarily been concerned with the affects of trampling, soil substrate, and plowing activities on artifact damage (e.g., Flenniken and Haggerty 1979; Gifford-Gonzalez et al. 1985; Mallouf 1981; McBrearty et al. 1998; Nielsen 1991; Pryor 1988; Roper 1976).

The most recent experimental work on the affects of trampling and soil substrate on artifact condition has been conducted by McBrearty et al. 1998. Their experiments involved foot trampling chert and obsidian debitage on sand and loam substrates with high and low artifact densities. They found that more chert flakes exhibited damage on loam (90 percent) than on a sandy substrate ( 25 percent). This is due to the fact that artifacts tend to be pushed down into the sand, whereas a loam is more compact and resistant, therefore placing greater stress on the artifacts. Overall, there was more edge damage present on flakes in loam vs. sandy soils ( 30 percent vs. 10 percent), and more broken flakes (17 percent vs. 5 percent). In addition, there are differences in edge damage ( 83 percent vs. 90 percent) and breakage rates (14 percent vs. 17 percent) for low vs. high artifact density scatters due to 
artifacts impacting against each other. In summary, soil substrate and artifact density appear to have a greater affect on artifact damage than material type differences (e.g., obsidian vs. chert). The clayey soils in the southwest corner of San Pedro Park and the high density of artifacts recovered from test units 1 and 2 indicate that both of these factors could have played an important role in artifact damage due to mechanical activities.

Mallouf's (1981) study of plow damage to a prehistoric cache of 173 lithic artifacts is also informative about the effects of mechanical disturbance. He found that 91 percent $(n=157)$ of the artifacts exhibited evidence of damage due to the plowing activities. Most of this consisted of simple nicks (41 percent), with some breakage ( 25 percent), "retouch" (18 percent), and other damage (16 percent). Malouff suggests that the most important factors affecting artifact damage are: proximity to surface (i.e., $5-17 \mathrm{~cm}$ ), the large size of the specimens (ca. $7 \mathrm{~cm}$ long), soil substrate, and type of plowing. He notes that the clayey soil probably played the greatest role in artifact damage. That is "the hard resistant clayey soils resulted in tremendous stresses being exerted on the specimens before the clay matrix broke under the force of the plow" (Mallouf 1981:55). This corroborates the previous view of McBrearty et al. (1998).

\section{Intrasite Breakage Patterns}

Table 18 presents information on test unit by flake condition. Approximately 80-90 percent of the flakes are broken within all the units; however, there is a significant difference in whole vs. flake fragments represented (chi-sq $=19.0, \mathrm{df}=4, \mathrm{p}=<0.01$ ), with relatively more whole flakes in TU 1 and broken flakes in TU 5. An evaluation of old vs. fresh breaks by test unit also reveals some significant differences (Table 19; chi$\mathrm{sq}=13.3, \mathrm{df}=4, \mathrm{p}=<0.01$ ). In this case, it is TU 1 which contains relatively more fresh breaks and TU 2 more old breaks; however, the percentage of fresh breaks varies from 4.6-12.2 percent, with TU 5 exhibiting the highest percentage. Nonetheless, the contingency table cell for TU 5 fresh breaks contains an adjusted residual of 1.7 which is slightly below a significant value of 1.96 . This is probably due to the small sample size for the cell $(n=16)$. Lastly, a comparison of presence/absence of damage by test unit also indicates some significant differences (Table 20; chi-sq=33.0, $\mathrm{df}=1, \mathrm{p}=<0.01$ ). $5-16$ percent of the flakes in these units exhibit damage, with TU 1 containing relatively fewer damaged flakes, and TUs 3 and 5 more damaged flakes. All together, it appears that artifacts in TU 5 exhibit the greatest amount of damage from postoccupational activities.

Table 18. TU by Flake Condition

Top value in cell represents artifact count, and bottom value represents adjusted residuals. Significant $(p<0.05)$ positive

values are shown in bold.

\begin{tabular}{|c|r|r|}
\hline \multirow{2}{*}{ TU } & \multicolumn{2}{|c|}{ Flake Condition } \\
\cline { 2 - 3 } & Whole & Fragment \\
\hline \multirow{2}{*}{1} & 140 & 513 \\
& $\mathbf{3 . 9}$ & -3.9 \\
\hline \multirow{2}{*}{2} & 79 & 434 \\
& -1.3 & 1.3 \\
\hline \multirow{2}{*}{3} & 20 & 130 \\
& -1.3 & 1.3 \\
\hline \multirow{2}{*}{4} & 3 & 28 \\
& -1.1 & 1.1 \\
\hline \multirow{2}{*}{5} & 13 & 131 \\
& -2.7 & 2.7 \\
\hline
\end{tabular}

chi-square $=19.0, \mathrm{df}=4, \mathrm{p}=<0.01$

Table 19. TU by Breakage

Top value in cell represents artifact count, and bottom value represents adjusted residuals. Significant $(p<0.05)$ positive values are shown in bold.

\begin{tabular}{|c|r|r|}
\hline \multirow{2}{*}{ TU } & \multicolumn{2}{|c|}{ Breakage } \\
\cline { 2 - 3 } & Old & \multicolumn{1}{|c|}{ Fresh } \\
\hline \multirow{2}{*}{1} & 460 & 53 \\
& -2.1 & $\mathbf{2 . 1}$ \\
\hline \multirow{2}{*}{2} & 414 & 20 \\
& $\mathbf{3 . 5}$ & -3.5 \\
\hline \multirow{2}{*}{3} & 118 & 12 \\
& -0.4 & 0.4 \\
\hline \multirow{2}{*}{4} & 26 & 2 \\
& 0.2 & -0.2 \\
\hline \multirow{2}{*}{5} & 115 & 16 \\
& -1.7 & 1.7 \\
\hline
\end{tabular}

chi-square $=13.3, \mathrm{df}=4, \mathrm{p}=<0.01$ 
Table 20. TU by Damage

Top value in cell represents artifact count, and bottom value represents adjusted residuals. Significant $(p<0.05)$ positive values are shown in bold.

\begin{tabular}{|c|r|r|}
\hline \multirow{2}{*}{ TU } & \multicolumn{2}{|c|}{ Damage } \\
\cline { 2 - 3 } & Absent & \multicolumn{1}{|c|}{ Present } \\
\hline \multirow{2}{*}{1} & 623 & 30 \\
& 4.9 & -4.9 \\
\hline \multirow{2}{*}{2} & 464 & 49 \\
& -0.9 & 0.9 \\
\hline \multirow{2}{*}{3} & 127 & 23 \\
& -3.1 & $\mathbf{3 . 1}$ \\
\hline \multirow{2}{*}{4} & 27 & 4 \\
& -0.9 & 0.9 \\
\hline \multirow{2}{*}{5} & 121 & 23 \\
& -3.3 & $\mathbf{3 . 3}$ \\
\hline
\end{tabular}

chi-square $=33.0, \mathrm{df}=1, \mathrm{p}=<0.01$

A closer comparison of TU 2 vs. TU 5 also underscores the increased impact to the TU 5 assemblage. Tables 21 to 23 are contingency tables of artifact condition, breakage, and damage by TUs 2 and 5 . Although there is no significant difference in artifact condition, TU 5 does contain significantly more fresh breaks and damaged flakes than TU 2 . Indeed, the analysis of the contingency table of flake breakage patterns was rejected by only a slight margin, with a $\mathrm{p}$ value of 0.051 . Otherwise, TU 5 would have also contained significantly more flake fragments.

Table 21 . TU 2 and 5 by Flake Condition

Top value in cell represents artifact count, and bottom value represents adjusted residuals.

\begin{tabular}{|c|r|r|}
\hline \multirow{2}{*}{ TU } & \multicolumn{2}{|c|}{ Flake Condition } \\
\cline { 2 - 3 } & Whole & Fragment \\
\hline \multirow{2}{*}{2} & 79 & 434 \\
& 1.9 & -1.9 \\
\hline \multirow{2}{*}{5} & 13 & 131 \\
& -1.9 & 1.9 \\
\hline
\end{tabular}

chi-square $=3.7, \mathrm{df}=1, \mathrm{p}=0.05$
Table 22 . TU 2 and 5 by Breakage

Top value in cell represents artifact count, and bottom value represents adjusted residuals. Significant $(p<0.05)$ positive values are shown in bold.

\begin{tabular}{|c|r|r|}
\hline \multirow{2}{*}{ TU } & \multicolumn{2}{|c|}{ Breakage } \\
\cline { 2 - 3 } & Old & \multicolumn{1}{|c|}{ Fresh } \\
\hline \multirow{2}{*}{2} & 414 & 20 \\
& $\mathbf{3 . 1}$ & -3.1 \\
\hline \multirow{2}{*}{5} & 115 & 16 \\
& -3.1 & $\mathbf{3 . 1}$ \\
\hline
\end{tabular}

chi-square $=9.7, \mathrm{df}=1, \mathrm{p}=<0.01$

Table 23. TU 2 and 5 by Damage

Top value in cell represents artifact count, and bottom value represents adjusted residuals. Significant $(p<0.05)$ positive values are shown in bold.

\begin{tabular}{|c|r|r|}
\hline \multirow{2}{*}{ TU } & \multicolumn{2}{|c|}{ Damage } \\
\cline { 2 - 3 } & Absent & Present \\
\hline \multirow{2}{*}{2} & 464 & 49 \\
& $\mathbf{2 . 2}$ & -2.2 \\
\hline \multirow{2}{*}{5} & 121 & 23 \\
& -2.2 & $\mathbf{2 . 2}$ \\
\hline
\end{tabular}

chi-square $=4.7, \mathrm{df}=1, \mathrm{p}=0.02$

Besides the variation in disturbance across the site, comparisons can also be made concerning the depth of these impacts. Table 24 presents the information on $10 \mathrm{~cm}$ excavation level by flake condition. These levels contain from 77-86 percent flake fragments, but there is no significant difference in flake condition between the five levels (chi-sq $=7.8, \mathrm{df}=1, \mathrm{p}=0.09$ ).

Table 24. Excavation Level by Flake Condition Top value in cell represents artifact count, and bottom value represents adjusted residuals. Significant $(p<0.05)$ positive values are shown in bold.

\begin{tabular}{|c|r|r|}
\hline \multirow{2}{*}{ Level } & \multicolumn{2}{|c|}{ Flake Condition } \\
\cline { 2 - 3 } & Whole & Fragment \\
\hline \multirow{2}{*}{1} & 25 & 154 \\
& -1.2 & 1.2 \\
\hline \multirow{2}{*}{2} & 99 & 505 \\
& -0.7 & 0.7 \\
\hline \multirow{2}{*}{3} & 46 & 252 \\
& -0.9 & 0.9 \\
\hline \multirow{2}{*}{4} & 66 & 229 \\
& 2.6 & -2.6 \\
\hline \multirow{2}{*}{5} & 19 & 84 \\
& 0.3 & -0.3 \\
\hline
\end{tabular}

chi-square $=7.8, \mathrm{df}=1, \mathrm{p}=0.09$ 
In contrast, Table 25 indicates that there are fewer fresh breaks by increasing depth, with Level 1 containing the most (13.6 percent) and Level 5 the least (3.6 percent). A chi-square analysis of the contingency table does indicate a significant difference in old vs. fresh breaks by level (chi-sq $=11.5, \mathrm{df}=1, \mathrm{p}=0.02$ ), with relatively more fresh breaks in Level 1. Artifact damage does not appear to have the same simple vertical distribution as represented by fresh breaks. The percentage of damaged flakes varies from 4.1-13.5 percent. Although there is a significant difference in the distribution of damage by level (Table 26; ch-sq $=18.0, \mathrm{df}=1$, $\mathrm{p}=<0.01$ ), there are relatively more damaged flakes in Level 3 and fewer in Level 4.

\section{Table 25. Excavation Level by Breakage}

Top value in cell represents artifact count, and bottom value represents adjusted residuals. Significant $(p<0.05)$ positive values are shown in bold.

\begin{tabular}{|c|r|r|}
\hline \multirow{2}{*}{ Level } & \multicolumn{2}{|c|}{ Breakage } \\
\cline { 2 - 3 } & Old & \multicolumn{1}{|c|}{ Fresh } \\
\hline \multirow{2}{*}{1} & 133 & 21 \\
& -2.5 & 2.5 \\
\hline \multirow{2}{*}{2} & 465 & 40 \\
& 0.5 & -0.5 \\
\hline \multirow{2}{*}{3} & 226 & 26 \\
& -1.2 & 1.2 \\
\hline \multirow{2}{*}{4} & 216 & 13 \\
& 1.7 & -1.7 \\
\hline \multirow{2}{*}{5} & 81 & 3 \\
& 1.7 & -1.7 \\
\hline
\end{tabular}

chi-square $=11.5, \mathrm{df}=1, \mathrm{p}=0.02$

Table 26. Excavation Level by Damage

Top value in cell represents artifact count, and bottom value represents adjusted residuals. Significant $(p<0.05)$ positive values are shown in bold.

\begin{tabular}{|c|r|r|}
\hline \multirow{2}{*}{ Level } & \multicolumn{2}{|c|}{ Damage } \\
\cline { 2 - 3 } & Absent & \multicolumn{1}{c|}{ Present } \\
\hline \multirow{2}{*}{1} & 165 & 14 \\
& 0.4 & -0.4 \\
\hline \multirow{2}{*}{2} & 552 & 52 \\
& 0 & 0 \\
\hline \multirow{2}{*}{3} & 257 & 41 \\
& -3.6 & $\mathbf{3 . 6}$ \\
\hline \multirow{2}{*}{4} & 283 & 12 \\
& $\mathbf{3 . 1}$ & -3.1 \\
\hline \multirow{2}{*}{5} & 95 & 8 \\
& 0.3 & -0.3 \\
\hline
\end{tabular}

chi-square $=18.0, \mathrm{df}=1, \mathrm{p}=<0.01$

\section{Summary}

The lithic assemblage from the southwest corner of San Pedro Park contains evidence of both core reduction and biface production activities. Diagnostic projectiles indicate that the site may contain both Late Archaic and Late Prehistoric occupations. The majority of the flakes on the site are broken. There are, however, several factors that can condition the breakage patterns of lithic artifacts. Analyses of the site's lithic assemblage indicates that flake breakage is in part due to biface production, the burning of artifacts, the presence of clayey soils and disturbance. It appears that TU 5 exhibits the greatest degree of post-depositional impact due to the presence of significantly more fresh breaks and surface/edge damage. 


\section{Historic Artifacts}

\section{Barbara A. Meissner}

There were 584 historic artifacts recovered during the 1998 project. Of these 432 (74 percent) were fragments of glass bottles. In general, the historic artifacts are probably recent, however, some may be from the Colonial period. A few artifacts are of particular interest and will be described below. Table 27 lists all historic artifacts in each of the STs and TUs.

\section{Ceramics}

This section will briefly describe the ceramics recovered during this project. The reader interested in more detail about ceramics from San Antonio sites should consult Dial (1992), Fox et al. (1976); Hard et al. (1995), and Meissner (1996). A total of 64 ceramics was recovered, of which 46 (71.9 percent) were unglazed, bone-tempered, unrefined earthenware. Thirtyeight were from Level 1 of Test Unit 1. This plainware could either be a prehistoric ceramic, often called

Table 27. Historic Artifacts

\begin{tabular}{|c|c|c|c|c|c|c|c|c|c|c|c|c|c|c|c|c|c|c|c|c|c|c|c|c|}
\hline \multirow[b]{3}{*}{ iits } & \multicolumn{12}{|c|}{ Household } & \multicolumn{2}{|c|}{ Tovs } & \multirow{3}{*}{ Arms } & \multicolumn{5}{|c|}{ Construction } & \multicolumn{3}{|c|}{ Misc. } & \multirow[b]{3}{*}{ Total } \\
\hline & & & & eram & & & & & & & & & & & & \multirow{2}{*}{ 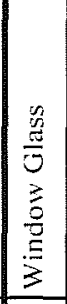 } & \multirow[b]{2}{*}{ 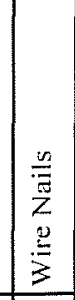 } & \multirow[b]{2}{*}{\begin{tabular}{|l}
$\frac{n}{\bar{T}}$ \\
$\bar{z}$ \\
$\bar{\Xi}$ \\
\end{tabular}} & \multirow[b]{2}{*}{ 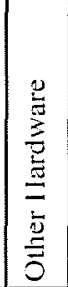 } & \multirow[b]{2}{*}{ 品 } & \multirow[b]{2}{*}{\begin{tabular}{|l|l}
$\frac{\pi}{2}$ \\
$\frac{0}{2}$
\end{tabular}} & \multirow[b]{2}{*}{ 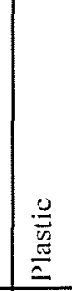 } & \multirow[b]{2}{*}{ כ. } & \\
\hline & 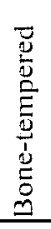 & 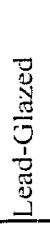 & 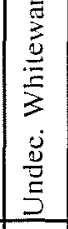 & 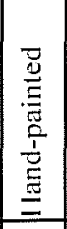 & 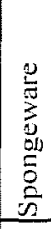 & 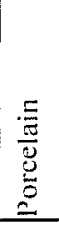 & 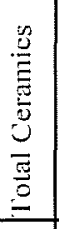 & $\begin{array}{l}\frac{n}{0} \\
\frac{n}{3} \\
0\end{array}$ & $\begin{array}{l}\frac{m}{5} \\
\frac{5}{9} \\
\frac{9}{5}\end{array}$ & 然 & 望 & 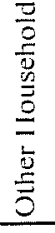 & 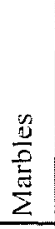 & $\begin{array}{l}\frac{n}{0} \\
\\
\end{array}$ & & & & & & & & & & \\
\hline ST 1 & & & & & & & 0 & 12 & & & & & & & & & & & & & & & & 12 \\
\hline ST 5 & & & & & & & 0 & 1 & & & & & & & & & & & & & & & & 1 \\
\hline ST 6 & & & & & & & 0 & 1 & & & & & & & & & & & & & & & & 1 \\
\hline ST 7 & & & & & & & 0 & 1 & & & & & & & & L & & & & & & & & 1 \\
\hline ST 8 & & & & & & & 0 & 1 & & & & & & & & & & & & & & & & 1 \\
\hline ST 14 & & & & & & & 0 & 2 & & & & & & & & E & & & & & 1 & \begin{tabular}{|l|}
6 \\
\end{tabular} & & 9 \\
\hline ST 15 & & & & & & & 0 & 3 & & & & & & & & & & & & & 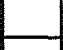 & & & 3 \\
\hline ST 17 & & & & & & & 0 & 2 & & & & & & & & & & & & & & & & 2 \\
\hline ST 18 & & 1 & & & & & 1 & & & & & & & & & & & & & & & & & 1 \\
\hline ST 20 & & & & & & & 0 & 1 & & & & & & & & E & & & & & & & & 1 \\
\hline ST 22 & & & & & & & 0 & & & & 1 & & & & & & & & & & & & & 1 \\
\hline ST 25 & & & 1 & & & & 1 & 2 & & & & & & & & & 1 & 1 & & & & & & 5 \\
\hline ST 29 & & & 1 & & & & 1 & 1 & & & & & & & & + & 1 & & & & & & & 3 \\
\hline ST 30 & & & & & & & 0 & 1 & & & & & & & & 1 & & & & & & & & 2 \\
\hline ST 31 & & & & & & & 1 & & & & & & & & & & & & & & & & - & 1 \\
\hline ST 32 & & & & & & & 0 & 48 & & & & & & & & & & & & & & & & 48 \\
\hline ST 33 & & & & & & & 0 & 1 & & 1 & & & & & & & & & & & & & & 2 \\
\hline ST 34 & & & & & & & 0 & 10 & & 1 & & & & & & & & & & & & & & 12 \\
\hline ST 35 & & & & & & & 1 & & 1 & & 1 & & & & & & & & & & & & _ & 3 \\
\hline ST 36 & & & 2 & & & & 2 & 3 & & & & & & & & & & & & & & & & 5 \\
\hline ST 37 & & & & & & & 0 & 2 & & & & & & & & & & & & & & & & 2 \\
\hline ST 38 & & & & & & & 0 & 3 & & & & & & & & 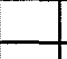 & 1 & & & & & & . & 4 \\
\hline ST 39 & & & & & & & 0 & 7 & & & & & & & & & & & & & & & & 7 \\
\hline TU 1 & 4 & & 3 & & 1 & & 8 & 53 & & 1 & & & 1 & & & 3 & & 3 & 2 & & 4 & 6 & & 81 \\
\hline TU 2 & & & 1 & & & & 1 & 49 & & 1 & 3 & 2 & & 1 & & 2 & 1 & & 1 & f & & 3 & 2 & 68 \\
\hline TU 3 & 40 & & & 1 & & & 41 & 217 & & & & & & & 0 & 1 & 2 & 2 & 1 & & 5 & & \begin{tabular}{|l}
3 \\
\end{tabular} & 272 \\
\hline TU 4 & & & & & & & 0 & 2 & & & 1 & & & & 2 & + & & & 2 & & -1 & $3 \mid$ & $3 \mid$ & 13 \\
\hline TU 5 & 2 & 2 & 3 & & & & 7 & 9 & & & 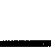 & & & & & 2 & 1 & & - & & 3 & 1 & $\square$ & 23 \\
\hline Total & 46 & $-\underline{3}$ & 11 & 1 & 1 & 2 & 64 & 432 & 1 & 4 & 6 & 2 & 1 & 1 & 3] & 9 & 7 & 6 & 6 & 1 & 13 & 20 & 8 & 584 \\
\hline
\end{tabular}


"Leon Plain," and found in many late-Prehistoric sites in the area (Hester 1995), or examples of the continuation of this ceramic tradition into Colonial times, often called Goliad ware (Fox et al. 1976:67). Unfortunately, no one has yet found a way to differentiate between the late-Prehistoric and Colonial versions of this ceramic (A. A. Fox, personal communication 1998), and they are usually considered one or the other depending on whether or not they have been found in association with Colonial-period artifacts. In San Pedro Park, both prehistoric and historic artifacts have been found in conjunction with these ceramics, making it impossible to gauge just how old they are.

Lead-glazed wares arrived in San Antonio beginning in the Colonial period. Although their popularity was greatest in the eighteenth and early nineteenth centuries, they are still occasionally sold in the area today (Dial 1992:34).

Three lead-glazed sherds were recovered, one from Level 5 of ST 18, and one from Level 1 of TU 5, and the other from Level 2 of TU 5. All three have thick bodies, and are of a dark glaze type that is probably Colonial (Dial 1992:32-33; Hard et al. 1995:47).

There is a total of 15 refined earthenwares sherds in this collection, 11 of which are undecorated whiteware fragments. One hand-painted rimsherd (Figure 41a) and a sponge-decorated sherd (Figure $4 \mathrm{lb}$ ) are probably from the early to mid-nineteenth century (Hard et al. 1995:47).

Two small sherds of porcelain were recovered, one is a fragment of the bottom of a small cup or bowl.

\section{Glass}

As was the case during the 1996 project (Chapter 3), fragments of bottle and jar glass are the most common historic artifacts recovered. Two sherds were a clear lavender color. This color is the result of chemical changes in clear glass containing manganese, as a result of exposure to sunlight. Although the method of making clear glass by adding manganese was known for centuries, it did not become a common practice

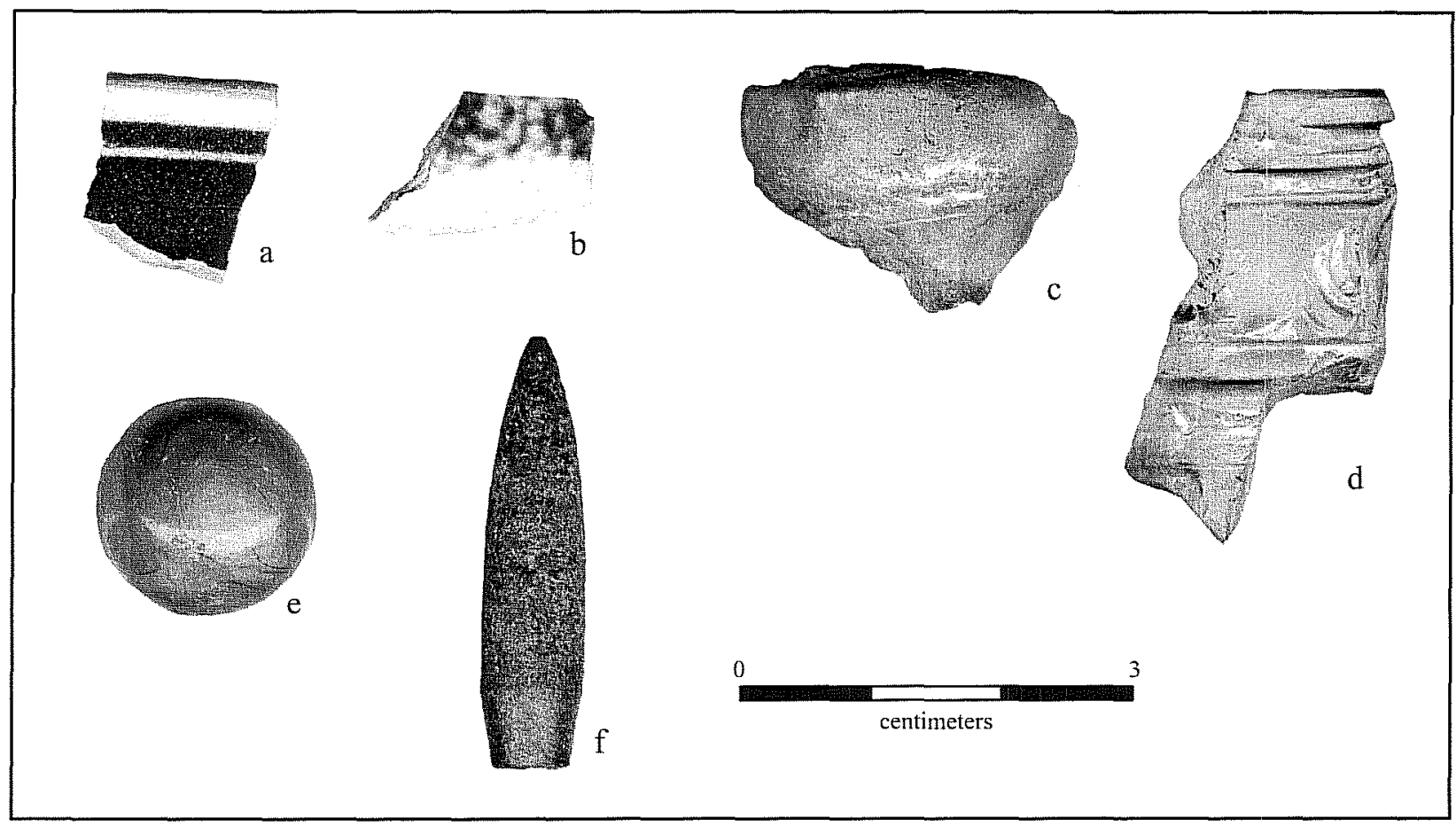

Figure 41. Selected Historic Artifacts. a) Handpainted whiteware rimsherd; b) Spongeware sherd; c) Handapplied bottle lip fragment; d) Machine-made bottle lip fragment; e) Stone marble; and f) an 8 mm Mauser rifle bullet. 
until the 1880s (Munsey 1970:55). This practice ended around 1915, because most available manganese was an export of Germany, and other techniques were used to achieve clear glass from that time on. This suggests that the two sherds of clear lavender glass are from the period between about 1880 and 1915 .

Only two bottle rims were collected. One (Figure 41c) is a fragment of a hand-applied lip, from TU 3, Level 1. Based on the size of the fragment it is not possible to determine if this bottle was molded or free-blown. The second rim (Figure 41d) was made in a bottle-making machine. The Owens machine was patented in 1903 and soon took over the bottle making industry (Munsey 1970:33). Therefore, this fragment dates to sometime in the twentieth century.

Two bottle fragments had lettering embossed on them. One read "FORBI". The other read "Forbid". Both are probably fragments of the phrase "Federal Law Forbids Resale or Reuse of This Bottle," which was often embossed on liquor bottles after the end of Prohibition in 1933 until 1964 (Munsey 1970:126).

\section{Other Household Items}

One utensil handle was recovered. This was a plain spoon or fork handle made of iron. In addition, a bottle opener, of the type that has a can-punch on one end, was recovered.

\section{Toys}

One fragment of porcelain appears to be part of the face of a doll. Although porcelain was used to make dolls for wealthy children throughout the nineteenth century, the Industrial Revolution had made them available to middle-class children by about 1860 (Meissner 1997:59). Such dolls were made of plastic after World War II (Meissner 1997:94).

A marble made of stone, commonly called an "agate" or "aggie" in the nineteenth century, was recovered from Test Unit 1, Level 1 (Figure 41e). This marble was probably made in Germany between 1869 and 1915 (Randall 1971). The swirls of color made these marbles popular, but this one is not well-made and may be of a less-expensive variety.

\section{Arms}

A total of three items were from the Arms category. One lead bullet, from TU 2, Level 2 is probably made for the commercial model of the German Mauser Rifle (Figure 41f). It is $8 \mathrm{~mm}$ in diameter, and has no steel jacket, both characteristics of rounds intended for the hunting rifle made by the Mauser Company after 1905 (Logan 1959:119-120).

A .177-caliber pellet for an air rifle was recovered from TU 4, Level 4. In the same unit/level a buckshot pellet $.7 \mathrm{~mm}$ in diameter was also found.

\section{Construction}

Items from this category were not recovered in any great quantity. As mentioned in Chapter 3, this is not surprising, since very little construction has taken place within the park, and apparently none has occurred in the southwest corner. Construction items are listed in Table 27 . The cut nails are probably from the nineteenth century, but all other construction materials appear to be twentieth century in nature.

\section{Miscellaneous}

Miscellaneous items include unidentifiable metal scrap and plastic fragments, and such things as bits of aluminum foil. These items are listed in Table 27. 


\section{Analysis of Vertebrate Faunal Remains}

\section{Barbara A. Meissner}

The bone recovered during the course of this project was sparse, which remains consistent with the results of the shovel testing conducted by Meissner (see Chapter 3). The total amount of bone recovered was 832 , which weighed $660.43 \mathrm{~g}$. The bone was in a highly fragmented condition, averaging less than a gram each.

\section{Methods}

Bones were bagged with other artifacts by unit and level in the field. In the laboratory all bone was washed, dried, and then bagged by unit and level. The bone was identified to the most specific possible taxon using the comparative collection at CAR, as well as several standard reference texts (Balkwill and Cumbaa 1992; Boessneck 1970, Gilbert 1990; Hildebrand 1955, Hillson 1986; Olsen 1960,1964, 1968; Schmid 1972). Identifications were conservative, i.e., bone which appeared to be cow-sized was not identified as Bos taurus unless it could be differentiated from $\mathrm{Bi}$ son and Equus species. An exception to this was bone which exhibited saw-marks, i.e., sawed bone of very large mammal size was assumed to be Bos taurus. The reason for this is that bison are known to have been absent from the area after about 1830 (Weniger 1997:23), and it was following this period that AngloAmerican butchering practices (specifically sawing of bone) were likely common. Although the presence of sawed horse bone is not inconceivable, it is considered unlikely.

Table 28. Identified Vertebrate Taxa from 1998 Project

\begin{tabular}{|c|c|c|c|}
\hline Taxon & Common name & Count & Weight \\
\hline Mammalia & Mammals & & \\
\hline Artiodactyl & Deer, sheep. or goat & 13 & 30.13 \\
\hline Bos taurus & Cattle & 8 & 62.75 \\
\hline Bovinae & Cattle or bison & 13 & 57.00 \\
\hline Canis sp. & Dog, covote, or wolf & 1 & 0.71 \\
\hline Didelphis virginiana & Opossum & 1. & 0.71 \\
\hline Equus cf caballos & Horse & 1 & 10.43 \\
\hline Odocoileus vriginianus & Whitetail deer & 10 & 32.98 \\
\hline Rodentia & Rodents & 1 & 0.05 \\
\hline \multirow[t]{7}{*}{ Suidae } & Pig or javelina (collared peccary) & 1 & 0.06 \\
\hline & Very large mammal (cow/bison/horse size) & 21 & 113.24 \\
\hline & Large mammal (deer/sheep/goat size) & 13 & 28.13 \\
\hline & Small mammal (raccoon/rabbit size) & 3 & 0.31 \\
\hline & Very small mammal (rat/mouse size) & 1. & 0.3 \\
\hline & Mammal-size indeterminate & 732 & 319.16 \\
\hline & \begin{tabular}{|r|} 
Total Mammals \\
\end{tabular} & 819 & 655.96 \\
\hline \multirow[t]{4}{*}{ Aves } & Birds & & \\
\hline & Large bird & 3 & 1.16 \\
\hline & Medium bird & 1 & 0.10 \\
\hline & Total Birds & 4 & 1.26 \\
\hline Reptilia & Reptiles & & \\
\hline Crotalus atrox & West. Diamondback Rattlesnake & 1 & 0.09 \\
\hline Colubridae & Non-poisonous snakes & 2 & 0.30 \\
\hline \multirow[t]{2}{*}{ Testudines } & Turtles & 5 & 2.35 \\
\hline & Total Reptiles & 8 & 2.74 \\
\hline \multirow[t]{3}{*}{ Osteichthyes } & Boney Fishes & & \\
\hline & Unidentified fish & 1 & 0.47 \\
\hline & Overall Total & 832 & 660.43 \\
\hline
\end{tabular}


All bone was weighed. Evidence of exposure to heat was noted on all bone. Element, portion of element, side, and evidence of immaturity was noted when possible. The degree of weathering, degree of chemical pitting, and whether or not bones had been gnawed was also noted whenever possible. Presence or absence of fresh breaks was recorded for all bone. A complete provenienced list of all data recovered from the bone is in Appendix E. A list of taxa identified is listed in Table 28, with counts and weights. When bone could be identified only to class (e.g., mammal, bird, etc.) an estimate of the size of the animal was made whenever possible.

\section{Analysis}

The specimens identified to at least the order taxonomic level were only 51 (6.1 percent of the total). This sample is too small, and from (at least potentially) too long a time-period to make an estimation of relative abundance of any significance. Whitetail deer was the most abundant species, but this is largely because the metatarsal of the whitetail is distinctive, making identification possible even on very small fragments. Note that only a single bone each was recovered from the four species identified in this collection.

Evidence of exposure to heat can indicate whether bone has been burned as a disposal method, since routine cooking and accidental burning of bone will normally only smoke-stain or char bone. In order to calcine bone, it must be exposed to intense heat for long periods, circumstances unlikely to occur unless bone is being deliberately burned (Lyman 1994:385). In this collection, 20.1 percent $(n=167)$ showed evidence of some heat alteration. Of these, 19.8 percent (33/167) were calcined or partially calcined, indicating the likelihood that at least some of the bone in this collection is the result of trash burning.

Evidence of gnawing by animals was very rare in this collection. Only three bones of the examined collection showed evidence of tooth marks, of which two had marks that could not be identified. One bone, a sawed long bone, probably from a cow, showed evidence of extensive gnawing by rodents.
Most of this bone does not appear to have been exposed to long periods of atmospheric weathering, however, only 22.7 percent $(n=189)$ of the bone was large enough to observe weathering damage. Of these, 68.8 percent $(n=130)$ showed no evidence of weathering damage. Of the remainder $(n=56)$, all but 3 showed only the early stages of weathering, i.e., fine longitudinal cracking and roughing of the surface texture.

Although this collection is too fragmented to allow a useful examination of butchering practices, evidence of butchering and other tool marks were identified. Table 28 lists the type of mark and the number of bones on which the mark was observed.

Table 29. Butcher Marks Observed

\begin{tabular}{|l|c|}
\hline \multicolumn{1}{|c|}{ Butcher Mark Type } & Count \\
\hline $\begin{array}{l}\text { Thin cut mark. Thin superficial cut, most likely } \\
\text { from knife. }\end{array}$ & 2 \\
\hline $\begin{array}{l}\text { Thick cut mark. Thicker superficial, from } \\
\text { heavy knife or small hatchet. }\end{array}$ & 1 \\
\hline $\begin{array}{l}\text { Chop mark. Heavy deep cut which may or may } \\
\text { not have completely severed bone. }\end{array}$ & 2 \\
\hline Hand saw cut. & 11 \\
\hline Machine saw cut. & 2 \\
\hline $\begin{array}{l}\text { Saw cut--indeterminate. Bone is saw cut, but } \\
\text { method used cannot be determined }\end{array}$ & 1 \\
\hline Impact scar. & $\mathbf{1 9}$ \\
\hline
\end{tabular}

In order to estimate the amount of damage to the faunal remains in the project area by the constructionrelated disturbance, all of the bone from the 1998 project was examined for recent breakage. Recent breaks could be identified by a difference in color on the broken surface of the bone, the rough texture of the break, and a break at a $90^{\circ}$ angle with the outer cortical surface (Johnson 1985:176). Fresh breaks do occur as part of the normal damage to artifacts during excavation. This is especially true when shovels are used, when the ground is very wet, or when the bone is in compacted clay matrix. How much of the bone breakage observed in this collection was caused by normal excavation damage cannot not be directly determined. However, in general, bone excavated in a similar manner, and in similar conditions, should have roughly the same percentage of fresh breakage. 
Table 30 shows the number of bone, the number exhibiting recent breaks, and the percentage of bone showing recent breaks for all STs and TUs. The small number of bone recovered in the shovel tests makes it difficult to assess the importance of fresh breakage as a source of bone fragmentation.

Table 30. Count and Percentage of Bone Exhibiting Fresh Breaks

\begin{tabular}{|l|r|r|r|}
\hline Unit & \multicolumn{1}{|c|}{$\begin{array}{r}\text { Total } \\
\text { Bone }\end{array}$} & $\begin{array}{c}\text { Recent } \\
\text { Breaks }\end{array}$ & $\begin{array}{c}\text { \% w } \\
\text { Recent } \\
\text { Breaks }\end{array}$ \\
\hline ST 6 & 6 & 4 & $66.7 \%$ \\
\hline ST 7 & 12 & 6 & $50.0 \%$ \\
\hline ST 15 & 10 & 7 & $70.0 \%$ \\
\hline ST 32 & 3 & 2 & $66.7 \%$ \\
\hline ST 33 & 24 & 5 & $20.8 \%$ \\
\hline ST 34 & 23 & 11 & $47.8 \%$ \\
\hline ST 35 & 3 & 2 & $66.7 \%$ \\
\hline ST 36 & 4 & 2 & $50.0 \%$ \\
\hline ST 37 & 11 & 5 & $45.5 \%$ \\
\hline ST 38 & 2 & 0 & $0.0 \%$ \\
\hline ST 39 & 3 & 2 & $66.7 \%$ \\
\hline ST 40 & 20 & 2 & $10.0 \%$ \\
\hline TU 1 & 309 & 111 & $35.9 \%$ \\
\hline TU 2 & 226 & 43 & $19.0 \%$ \\
\hline TU 3 & 130 & 40 & $30.8 \%$ \\
\hline TU 4 & 3 & 0 & $0.0 \%$ \\
\hline TU 5 & 43 & 32 & $74.4 \%$ \\
\hline Total & $\mathbf{8 3 2}$ & $\mathbf{2 7 4}$ & $\mathbf{3 2 . 9 \%}$ \\
\hline
\end{tabular}

The test units had much higher bone counts. If the construction-related damage to the southwest corner of the park affected the faunal remains, we should expect to see a great deal more bone with fresh breaks in the test units in the more disturbed areas, that is TUs 3-5. Table 31 shows the number of bones with fresh and old breaks Test Unit excavations. The adjusted residuals show that TU1 and TU5 have significantly higher frequencies of bone with fresh breaks, while TU2 had a significant number of bones with old breaks. TU4 only had three bones so the pattern in this unit is not reliable. TU3 had no significant variation in the number of fresh and old breaks. The bone breakage evidence shows that there has been more recent disturbance in TU1 and TU 5, especially in the latter.
Table 31. Number of Bones with Fresh and Old

\begin{tabular}{|c|c|c|c|c|}
\hline & & \multicolumn{2}{|c|}{ Breakage } & \\
\hline \multicolumn{2}{|r|}{ Unit } & Fresh & Old Only & Total \\
\hline \multirow{2}{*}{ TU1 } & Count & 111 & 198 & \multirow{2}{*}{309} \\
\hline & Adjusted residual & 201 & -2.1 & \\
\hline \multirow{2}{*}{ TU2 } & Count & 43 & 183 & \multirow{2}{*}{226} \\
\hline & Adjusted residual & -5 & 5 & \\
\hline \multirow{2}{*}{ TU3 } & Count & 40 & 90 & \multirow{2}{*}{130} \\
\hline & Adjusted residual & -0.03 & 0.03 & \\
\hline \multirow{2}{*}{ TU4 } & Count & 0 & 3 & \multirow{2}{*}{3} \\
\hline & Adjusted residual & -1.2 & 1.2 & \\
\hline \multirow{2}{*}{ TU5 } & Count & 32 & 11 & \multirow{2}{*}{43} \\
\hline & Adjusted residual & 6.2 & -6.2 & \\
\hline & Total Count & 226 & 485 & 711 \\
\hline
\end{tabular}




\section{Nature of Impacts to Cultural Deposits in Project Area}

\section{Previous Impacts}

Meissner's shovel tests in 1996 indicated that some previous impacts had occurred in the area. In particular, her shovel tests 31,36 and 38 had evidence of previous construction activities. (see Table 2). These impacts were probably of limited extent. An examination of Figure 27 indicates that Meissner's shovel test 31 is less than $10 \mathrm{~m}$ from Test Units 1 and 2 . These two test units showed no evidence of disturbance before that caused by Ramex, Incorporated. On the other hand, Test Unit 4 shows evidence of previous disturbance in the form of components of an underground sprinkler system (see Figure 33), while Meissner's BHT C, located just about $5 \mathrm{~m}$ east of this test unit, showed no evidence of disturbance below the top $3 \mathrm{~cm}$ (see Table 5).

\section{Recent Impacts}

This project investigated three types of impact:

a) Compaction of the existing matrix;

b) Dumping of foreign fill on the project area; and

c) Removal of the natural matrix.

The severity of each impact type and its affect on the cultural deposits at the site are evaluated below.

Although no formal compaction studies were conducted by CAR, it is evident from the manual excavation of the shovel tests and test units in the southwest comer that the natural clay loam has been artificially compacted to various degrees. In some areas of the site, the soil now fractures conchoidally. The only area free of compaction within the $1998 \mathrm{CAR}$ shovel test grid was the approximately $200 \mathrm{~m}^{2}$ area surrounding a large pecan tree in the north end of the grid and the ca. $75 \mathrm{~m}^{2}$ area around the small oak trees at the southwest corner of the grid. This accounts for approximately 13 percent of the grid area. In other words, of the sampled $2,100 \mathrm{~m}^{2}$, approximately $1825 \mathrm{~m}^{2}$ have been compacted. Furthermore, the degree of compaction is less intensive at the north end of the shovel test grid (north of the pecan tree). The source of compaction probably is three-fold. First, gravel, sand, and other materials were stockpiled in the area. Second, heavy machinery was parked in the area and used to move the stockpiled materials. Finally, the area was graded after the stockpiles were removed.

Studies have demonstrated that artifacts in a loam matrix are much more likely to be impacted by trampling-type impacts than artifacts in a sandy matrix (McBrearty et al. 1998). Clay soils also put a tremendous amount of stress on artifacts when subjected to similar types of impacts (Mallouf 1981). The analysis of artifacts from the test units indicates that there are more fresh breaks on flakes in TUs 3 and 5 when compared to TU 1. Furthermore, artifacts from TU 5 appear to exhibit the greatest relative frequency of fresh breaks. Bone from TU 5 also shows the highest frequency of fresh breaks. This supports the soil and sediment texture observed during the excavations of the shovel tests and test units, indicating that the greatest amount of compaction is in the area south of the large pecan tree.

The dumping and stockpiling of gravel and sand in the project area not only contributed to the compaction of the natural surface, but the graded remnants of those materials obscure the surface of the underlying clay loam. This made it impossible to compare the original ground surface elevations to the current elevations of the underlying clay loam without excavation. Additionally, it is possible that cultural material included in the foreign fill is now mixed with upper level artifacts originally deposited at the park. Therefore, artifacts from the contact zone between the fill and the underlying clay loam are in poor archaeological context.

The final impact, the possible removal or redistribution of clay loam from the original surface, is the most difficult to assess. Because the original contour map of the park was created using very few elevational points in the southwest corner, it is difficult to determine precisely the difference between the original ground surface and the top of the clay loam as documented by this project. The overlying fill in the majority of the tested area is variable in thickness, and 
the exact topography of the buried clay loam is obscured. One line of evidence indicates that no material was removed prior to the introduction of the gravel fill. This is based on the top of the sprinkler assembly in TU 4 coinciding with the top of the clay loam. Unfortunately, because any other sprinklers are now also buried by the construction fill, it is impossible to know if they also coincide with the original ground surface elevation or if they were buried under later sediment accumulations.

The limited shovel test data, however, suggest that soil was removed from sections of the project area (see Figures 36 and 37). Figure 37 suggests that at least $30 \mathrm{~cm}$ of original clay loam was removed in some areas. If this is the case, it is likely that important archaeological deposits were destroyed. The artifact counts in Meissner's STs 29, 30, 32, and 33, and Houk's Test Units 1-3 indicate that the cultural deposits in that area were very dense. In TUs 1-3 artifact counts were especially high at depths of 10 to 20 $\mathrm{cm}$ and at 30 to $40 \mathrm{~cm}$ (see Figure 42). Assuming that these deposits were spread over a large area, the removal of the upper $20 \mathrm{~cm}$ of material would completely destroy the uppermost prehistoric component. 


\section{Summary of the 1998 Investigations}

The testing project documented intact archaeological deposits in the investigated area. Data from TU 1 indicates that there are prehistoric cultural deposits throughout the upper $50 \mathrm{~cm}$ in the north end of the project area. These deposits contain Late Prehistoric and Transitional Archaic diagnostic artifacts. Additionally, they contain significant quantities of lithic debris, burned rock, and faunal remains. The data recovered from TUs 1 and 2 suggest that there are multiple, stratified prehistoric components. Figure 42 illustrates the peaks in artifact quantities in Levels 2 and 4 . There is clearly some degree of mixing of components in Levels 1 and 2 of all five units, but the majority of the historic and modern materials were encountered in the upper $10-15 \mathrm{~cm}$ of each unit.
The testing project documented significant, stratified prehistoric cultural deposits in the southwest corner of San Pedro Park. These deposits have been impacted by construction-related activities. The primary impact is machine compaction of the upper $20-30 \mathrm{~cm}$ of clay loam across most of the tested area. The compaction has damaged the artifacts in these levels. The stockpiling of gravel and sand across the project area probably contributed to the compaction. The grading of this material has obscured the original ground surface and made it difficult to determine the impact to the underlying clay loam. The testing data suggest, however, that one of the impacts to the site was the removal of clay loam from certain areas (see Figures 36 and 37). Therefore, we conclude that the actions of Ramex, Incorporated have impacted significant archaeological deposits.

Figure 42. Graph showing Historic and Prehistoric artifact counts by level in Test Units.

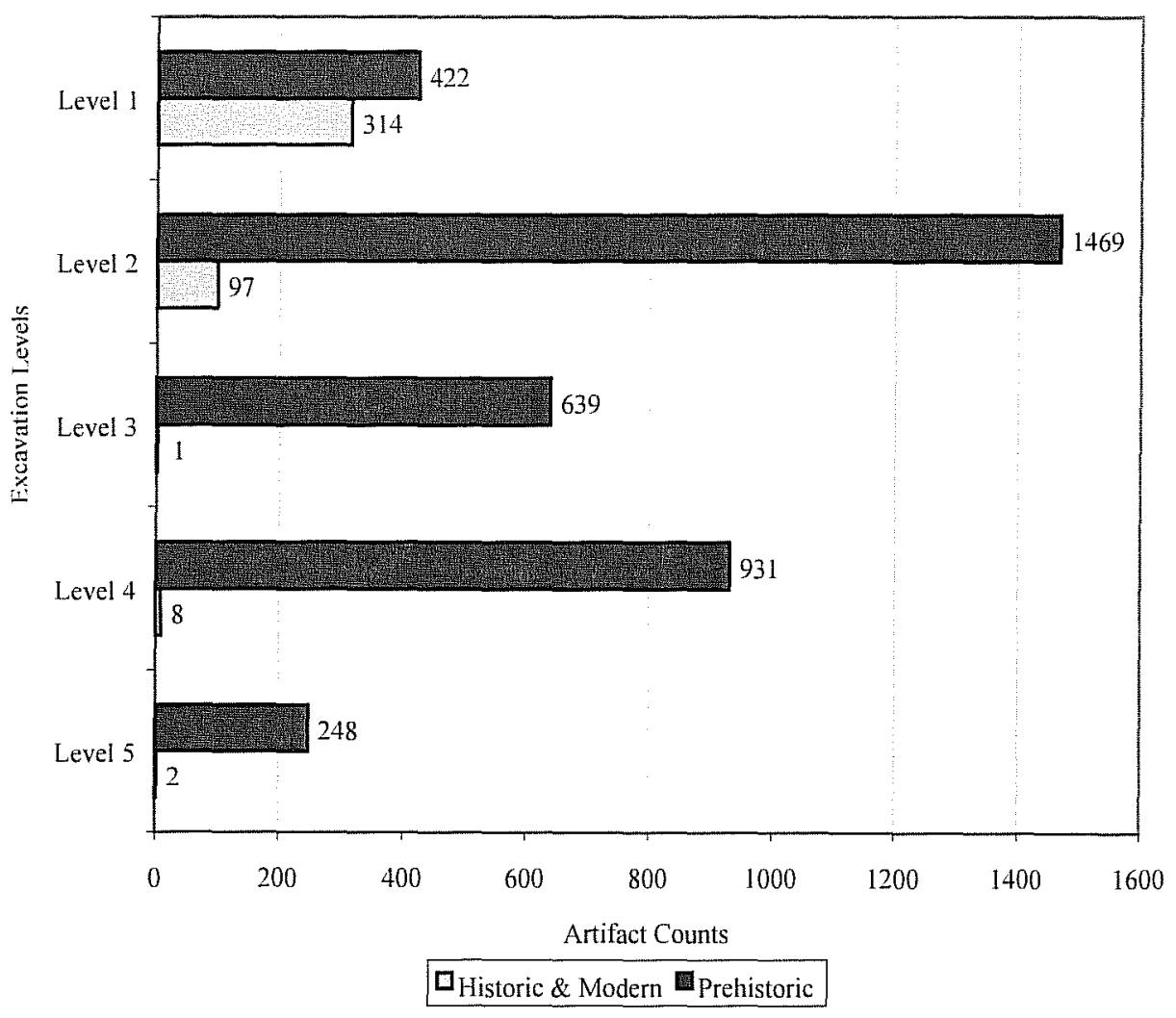




\section{Chapter 5: Recommendations for Management of Cultural Resources at San Pedro Park}

\section{Barbara A. Meissner}

\section{Introduction}

In general, it is best to avoid any disturbance of the ground in the park, because there is a potential for sub-surface cultural deposits over the entire park, except those areas where the sediments have previously been removed down to bedrock. Therefore, except in those areas, before beginning any activities that will disturb the ground inside the park, park managers should consult with the Texas Historical Commission (THC), and an archaeologist in order to plan and carry out any needed preliminary cultural resource investigations. The purpose of this chapter is to provide a set of recommendations for the management of the cultural resources of San Pedro Park. These recommendations should be used only as guidelines, as specific procedures must be planned in coordination with THC and an archaeologist. Specific management strategies cannot be made or carried out until the exact nature of the potential impact to cultural resources is known, including the area to be impacted, the nature of the known cultural deposits in the area, and the degree of damage to cultural resources already documented in the area.

In order to explain the reasons for the recommendations outlined below, it will first be necessary to summarize the nature of potential cultural resources within the park, and the nature of damage to these resources that has already been documented, including a brief summary of the results of the testing projects in the park in 1996 and 1998 described in this volume. This chapter will then define a list of cultural resource management procedures, and an accompanying table further defines which of these procedures is recommended for each area of the park, for each of the several types of impact. Maps of the park are included, indicating where these procedures should be implemented. Finally, we will recommend a program to expand public education by explaining the importance and history of the park, and the role it continues to play in the cultural fabric of San Antonio.

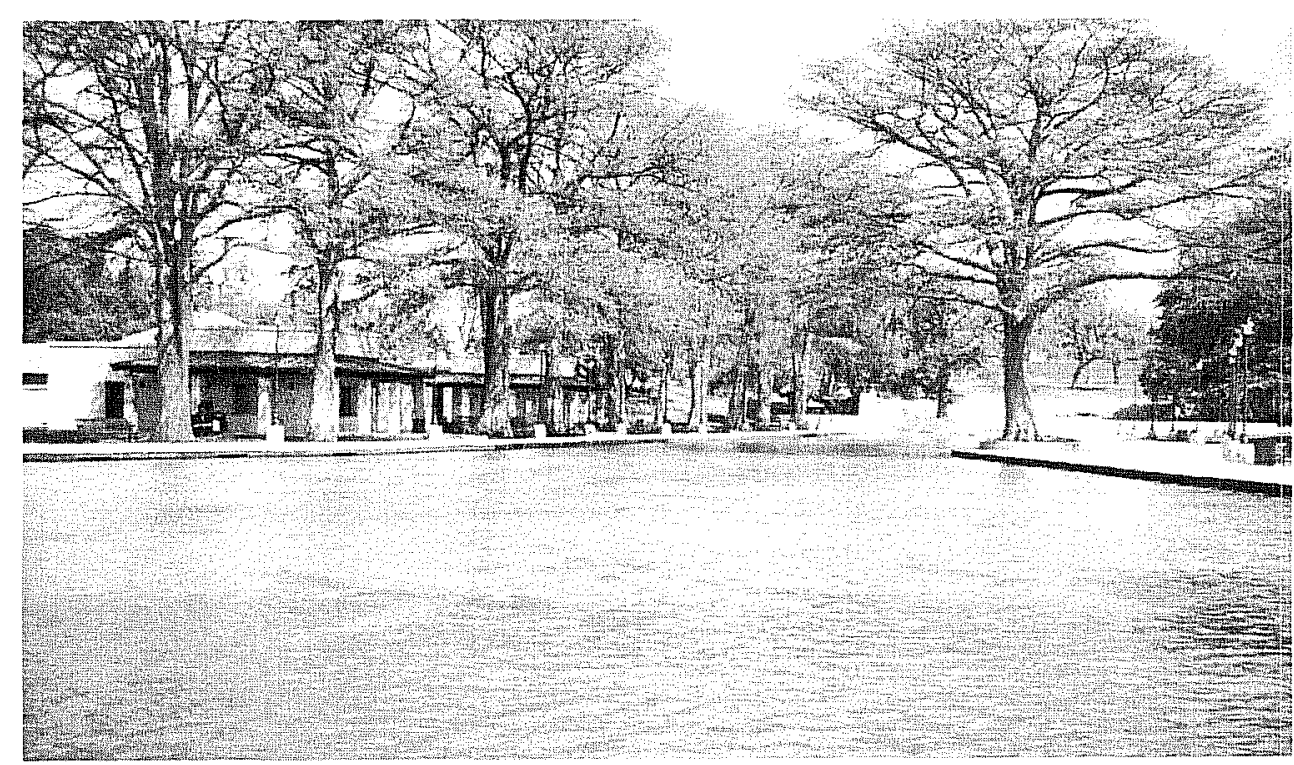

Figure 43. Photograph of the new pond in San Pedro Park. Looking northwest.

This pond covers roughly the same area as the original natural pool (see Figure 9). 
Figure 44. The southwest corner of the park today. Looking southwest. Note that the drainage ditches have been filled, and park roads and parking lots removed.

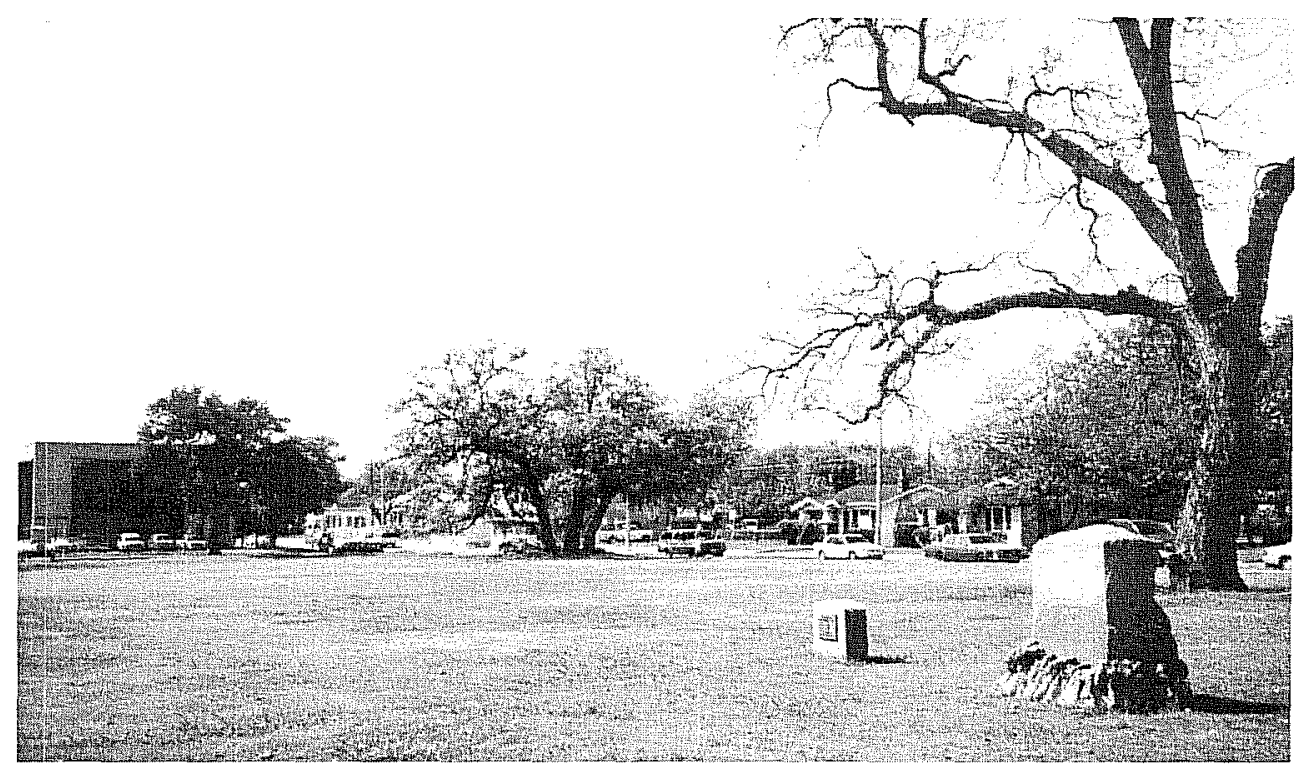

In the past two years the planned renovations of the park, including the building of a pond that more closely resembles the original natural pond (Figure 43), the filling of drainage ditches along the western side of the park, and the removal of a number of parking lots and roadways within the southwestern quadrant of the park (Figure 44) have resulted in a somewhat different park than that shown in the maps in the previous chapters of this volume. The maps in this chapter show the park as it is today.

\section{Summary of Potential Cultural Resources}

Although there had been only a single professional excavation in San Pedro Park before 1996 (Fox 1975), there is considerable evidence that the area had been used by Native American groups for many thousands of years. Bexar County, in general, has a number of Paleoindian sites, indicating that the area had been exploited for at least 11,000 years (Black 1989; Collins 1995; Orchard and Campbell 1954). Amateur archaeologist, C. D. Orchard described a site eroding out in the northeastern portion of the park in the early 1930 s, which he described as "an oval midden area having a maximum length of about 400 feet", from which he collected Native American pottery sherds (Orchard and
Campbell 1960:7). The projectile points known to have been found in the park indicate that it was in use for at least 7,000 years (Chapter 3; see also Orchard and Campbell 1960:7; Woolford 1935).

Most of the oldest cultural deposits may be deeply buried in alluvial and colluvial sediments deposited during thousands of years. The test borings described in Figure 7 show that there is more than 9 meters (30 feet) of sediments in the southern two-thirds of the park (see also Figure 6). It is well known that important Early Archaic and Paleoindian (11,000-6,000 year-old) deposits are often found deeply buried in such settings. Any project that will disturb deep sediments within the grounds, especially in the southern portion of the park, must take the possibility of encountering deeply buried cultural deposits into consideration.

In addition to the occupation by Native Americans for possibly as much as 11,000 years, we know that the first permanent Spanish occupation of San Antonio was located within a very short distance of the springs, and the first of San Antonio's many acequias began within the park (see Chapter 2). Other important historic events include the location of "Camp Crockett" within the park during the war with Mexico in the late 1840 s. Nineteenth century park concessions, 
including beer gardens, candy stores, and the zoo, are also of interest to the history of the community. Remains of any or all of these occupations may still be present in the park today, however, due to the lack of archaeological investigations very little information about what cultural resources may remain in San Pedro Park was available until the testing described in this volume and in Houk (1999).

\section{Summary of Known Impacts on Cultural Resources}

\section{Project Summaries}

\section{The 1977 Project (Fox 1978)}

In 1977, a small portion of the Alazán acequia running above the main spring was uncovered and reconstructed. The excavation was limited to the small section of the acequia. The acequia was found intact, showing at least two building episodes and a filling episode. No other deposits were uncovered.

\section{The 1996 Project}

The purpose of this testing project was to determine the exact location where the remains of the Alazán acequia would be impacted by a planned drainage improvement project under North Flores Street, and to then assess the likelihood that the project would significantly impact buried cultural material (see Chapter 3 of this volume).

The results of the shovel testing in the park indicated that there were previously undisturbed areas along the western edge of the park that were likely to contain intact buried cultural deposits. A thin scatter of historic artifacts was present along the entire western edge of the park, confined for the most part to the upper 20 $\mathrm{cm}$. Analysis of prehistoric artifacts from the shovel tests revealed that a site is present along the entire western edge of the park. The greatest density of prehistoric artifacts occurred from 20 to $40 \mathrm{~cm}$ below the surface in that area.

\section{The First 1998 Project}

The data from 40 shovel tests and five $1-\mathrm{x}-2 \mathrm{~m}$ test units excavated in the first project in 1998 (see Chapter 4 of this volume), further documented significant, stratified prehistoric cultural deposits in the southwest corner of San Pedro Park, although these deposits have been impacted by construction-related activities. The primary impact is machine compaction of the upper 20 to $30 \mathrm{~cm}$ of clay loam across most of the tested area. The deposits below this level are intact.

\section{The Second 1998 Project (Houk 1999)}

CAR personnel conducted an archaeological survey and limited testing of portions of the park for the City of San Antonio, Department of Parks and Recreation in preparation for planned infrastructure repair and improvements. A series of 44 shovel tests in 11 transects were dug, mostly around the pool and bathhouse area and to the south of that area all the way to Myrtle Street (see Houk 1999:12). In addition, 2 backhoe trenches were dug. The testing results showed that although a large part of the project area had been disturbed to at least $50 \mathrm{~cm}$ below the modern surface, there were areas where intact deposits of prehistoric and historic cultural materials remained.

\section{Other Known Impacts in the Park}

Examination of various historic accounts, as well as maps, indicates areas where major construction episodes have disturbed the park. The northeastern section of the park is known to have been the site of a limestone quarry. This quarrying may have begun as early as the Colonial period (see Chapter 2). After the Civil War, a series of small ponds were constructed west of the natural pond (see Figure 9). These would have impacted previous cultural deposits. During this period there were a number of buildings and garden constructions done in the east-central part of the park, and somewhat later a zoo was located on the west side of the park. The majority of the park, however, has not been tested, and the nature of the impact of various construction episodes is unknown. To a large extent, therefore, we do not know what cultural resources remain in the park, making protection of these resources problematic. 


\section{Cultural Resource Management Procedures}

Cultural resource management (CRM) procedures recommended in this chapter will depend on the threedimensional extent of the expected impact, the nature of known deposits in the project area, and the degree of damage known to have already occurred in the area. Commonly-used CRM procedures follow.

\section{Monitoring}

An archaeologist closely observes construction activities, recording any encountered features and/or artifacts. This is done so that if significant cultural deposits or features are located during construction, the process of evaluation can begin immediately. The archaeologists will recommend temporarily stopping construction only if necessary in order to properly record an important feature or to make plans to limit damage to important cultural deposits. Monitoring alone should be done only when the likelihood of encountering significant, intact cultural resources is low.

\section{Testing}

Testing is utilized to locate cultural resources, as well as to evaluate the significance of such resources and the degree to which they are intact. There are three types of testing normally used:

\section{Shovel Testing}

Holes about $30 \mathrm{~cm}\left(12^{\prime \prime}\right)$ in diameter are dug by shovel to a depth of at least $50 \mathrm{~cm}\left(20^{\prime \prime}\right)$. This is a standard testing procedure in areas where cultural resources are unknown. In some cases deeper shovel tests can be useful, however the practical limit on shovel tests is about $70-80 \mathrm{~cm}$ $\left(2.3^{\prime}-2.9^{\prime}\right)$. Deeper testing must be done in $1 \times 1$ $\mathrm{m}$ units (see below). The number of tests and the distance between them will be decided based on the extent of expected impact, and likelihood that intact cultural deposits may be found. If possibly intact cultural deposits are encountered, "test units" may be necessary in order to determine the significance of these deposits.

\section{Test Units}

$1 \mathrm{x} 1$ meter units are excavated to a depth of at least the impact zone. The number and placement of such units will be decided based on information from shovel tests, backhoe trenches, or other sources of information about cultural deposits. Test units are used to estimate the importance of cultural deposits. Test units are generally excavated when cultural deposits are known to be present, are strongly suspected to be present, or when testing below a depth of $70-80 \mathrm{~cm}\left(2.3^{\prime}-2.9^{\prime}\right)$ is needed (see Shovel Tests). If the test units find the cultural deposits to be significant, plans may be changed to avoid further impact to these deposits, or, if this is not possible, the damage to these deposits may be mitigated by further archaeological work.

\section{Backhoe Trenching}

Backhoe trenching is necessary whenever a planned impact will be deeper than about 2 meters $\left(6.6^{\prime}\right)$, except in the areas where deposits are known to have been destroyed to bedrock. Backhoe trenches allow detailed study of the geomorphology of the area and can be used to look for the deeply buried cultural deposits that may be present, especially in the southern $2 / 3$ of the park. If such deposits are found in backhoe trenches, test units should be placed to further examine these deposits. If the test units find the cultural deposits to be significant, plans may be changed to avoid further impact to these deposits, or, if this is not possible, the damage to these deposits may be mitigated by further archaeological work.

\section{Mitigation}

Mitigation is needed when significant, intact cultural deposits are present, as delineated by testing, and where disturbance of these deposits cannot be avoided. The exact nature and extent of the mitigation must be planned in cooperation with THC, the Parks and Recreation Department, and the archaeological contractor hired to perform this service. In general, the object of mitigation is to record any features that will be impacted and to collect artifacts in a controlled manner so that the nature of the cultural deposits, and what they can tell us about previous inhabitants can be published. This may involve only limited excavation. 
However, if extensive impact to important deposits cannot be avoided, major excavations may be needed to mitigate this damage.

\section{Recommended Cultural Resource Management Procedures}

Figures 45 through 48 show detailed maps of each of four quadrants of the park. Each map is color-coded to show the nature of previous impacts and knowledge of cultural resources. These color zones are:

- ReD

Areas where cultural deposits or features are known to exist.

- GreEN

Areas where the nature of the cultural deposits is unknown or where known deposits are not deep, limited to the upper $50 \mathrm{~cm}\left(20^{\prime \prime}\right)$.

- Light Blue

Areas where sediments are disturbed to at least a depth of $50 \mathrm{~cm}\left(20^{\prime \prime}\right)$.

- Dark Blue

Areas where sediments are disturbed to at least a depth of $183 \mathrm{~cm}\left(6^{\prime}\right)$
Table 32 is a matrix of recommendations for management of cultural resources in each color zone in Figures 45 to 48 , depending on the impact type. The impact types are defined as:

- IMPACT LiMited TO UPPER 6" (15 cM)

The entire park is assumed to have been disturbed to a depth of at least 6" $(15 \mathrm{~cm})$, so any activity (such as laying sod) that does not disturb the ground below this level will not impact intact deposits.

- Surface area of Impact is Limited to 3' (90 CM) IN DIAMETER OR LESS

This includes such activities as planting small trees or placing concrete footings for playground equipment. While this impact may be deeper than 6" $(15 \mathrm{~cm})$ its area is so small that impact to cultural resources will probably be limited.

- Impact DePth is 6" to 20" (15-50 CM)

This usually includes such activities as sidewalk construction, placement of concrete or stone wall footings, etc.

- IMPACT DEPTH is 20" to 6' (50-183 CM)

This will include such activities as some types of building construction, drainage ditches, and probably road construction.

- IMPaCt DePth is GReater than 6' (>183 cM) This category includes such activities as construction of buildings with basements or the construction of major footings.

Table 32. Cultural Resource Management Recommendations defined by Nature of Known Deposits, Previous Impacts, and Type of Planned Impact

\begin{tabular}{|c|c|c|c|c|c|}
\hline & \multicolumn{5}{|c|}{ Type of Impact } \\
\cline { 2 - 6 } & $\begin{array}{c}\text { Upper 6" } \\
(38 \mathrm{~cm}) \\
\text { Only }\end{array}$ & $\begin{array}{c}\text { Area }<3^{\prime} \\
(90 \mathrm{~cm}) \text { in } \\
\text { diameter }\end{array}$ & $\begin{array}{c}\text { Impact depth } \\
66^{\prime \prime} \text { to 20" } \\
(15-50 \mathrm{~cm})\end{array}$ & $\begin{array}{c}\text { Impact depth } \\
20^{\prime \prime} \text { to 6' } \\
(50-183 \mathrm{~cm})\end{array}$ & $\begin{array}{c}\text { Impact depth } \\
>6^{\prime}(183 \mathrm{~cm})\end{array}$ \\
\hline Yellow & None & None & None & None & None \\
\hline Green & None & Monitor & Testing & Testing & Testing \\
\hline Light Blue & None & Monitor & Monitor & Testing & Testing \\
\hline Dark Blue & None & Monitor & Monitor & Monitor & Testing \\
\hline Red & None & Avoid & Avoid & Avoid & Avoid \\
\hline
\end{tabular}




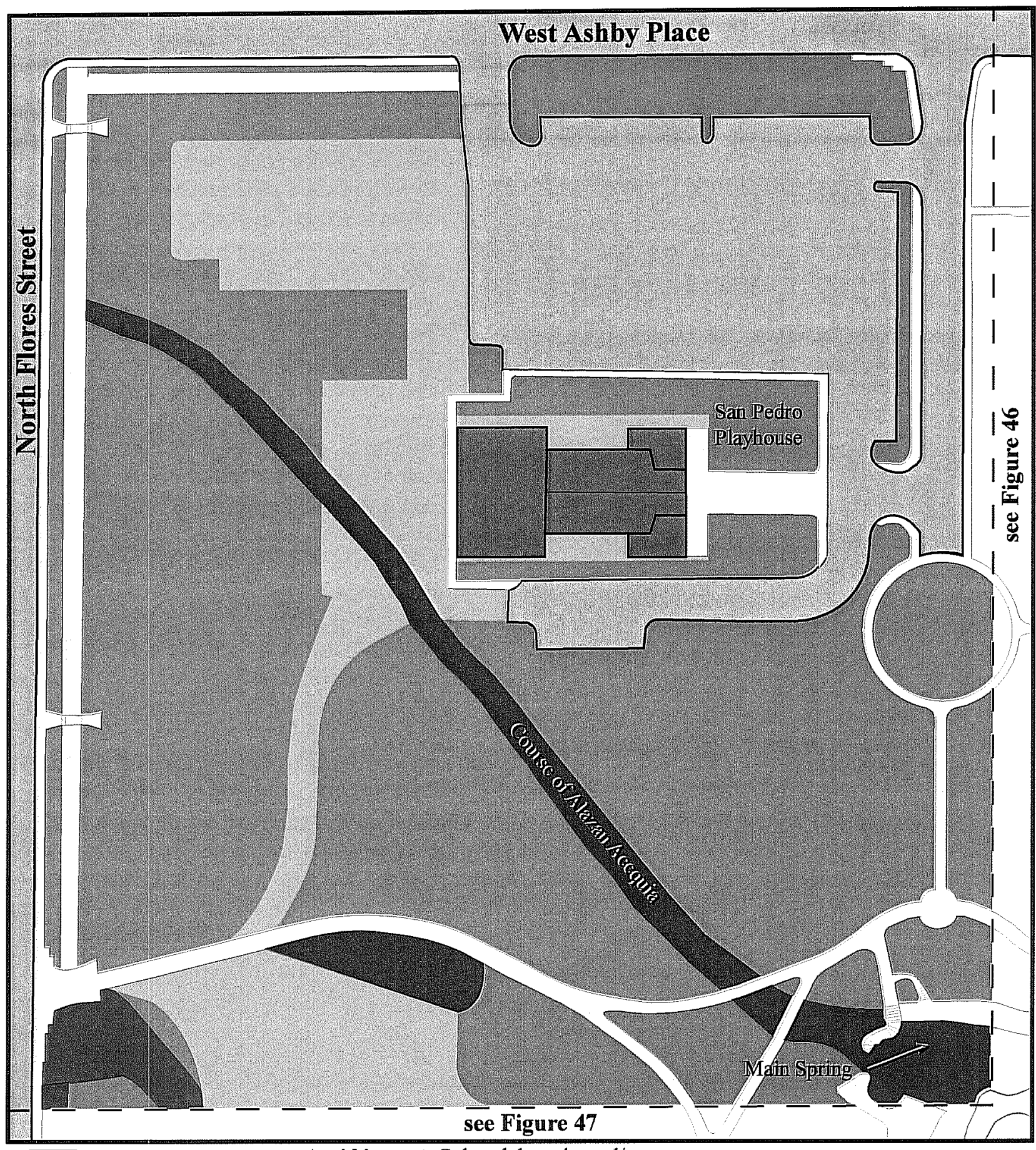

Buildings Avoid impact. Cultural deposits and/or features known in area.

Sidewalks and other pavements

Roads

$\star \ldots$ Fence line
Testing recommended. Nature of cultural resources unknown or known disturbances are superficial.

Testing recommended only if impact extends below $50 \mathrm{~cm}\left(20^{\prime \prime}\right)$. Deposits above this level are known to be disturbed.
Testing needed (backhoe) only if impact zone is deeper than 2 meters (6.6') below surface. Deposits known to be disturbed above this level.

No testing required. Deposits known to be destroyed.

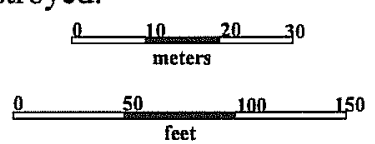

Figure 45. Map of northwest quadrant of San Pedro Park where testing is recommended if impacts are planned. 

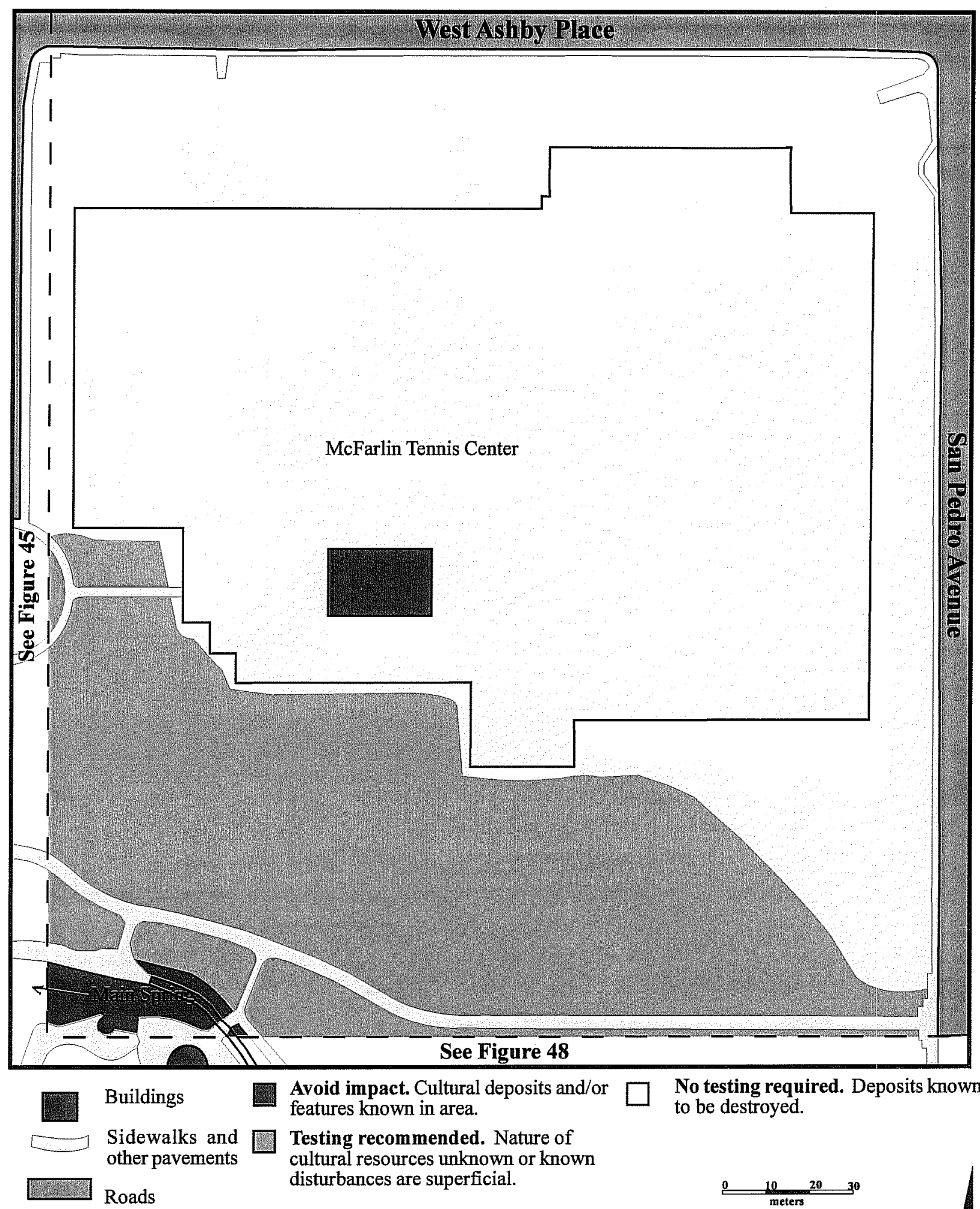

Avoid impact. Cultural deposits and/or features known in area.

Testing recommended. Nature of cultural resources unknown
disturbances are superficial.
No testing required. Deposits known to be destroyed.

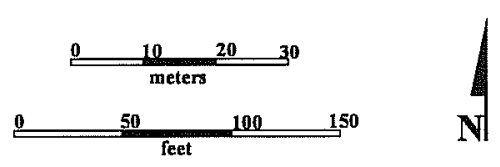

Figure 46. Map of northeast quadrant of San Pedro Park where testing is recommended if impacts are planned. 

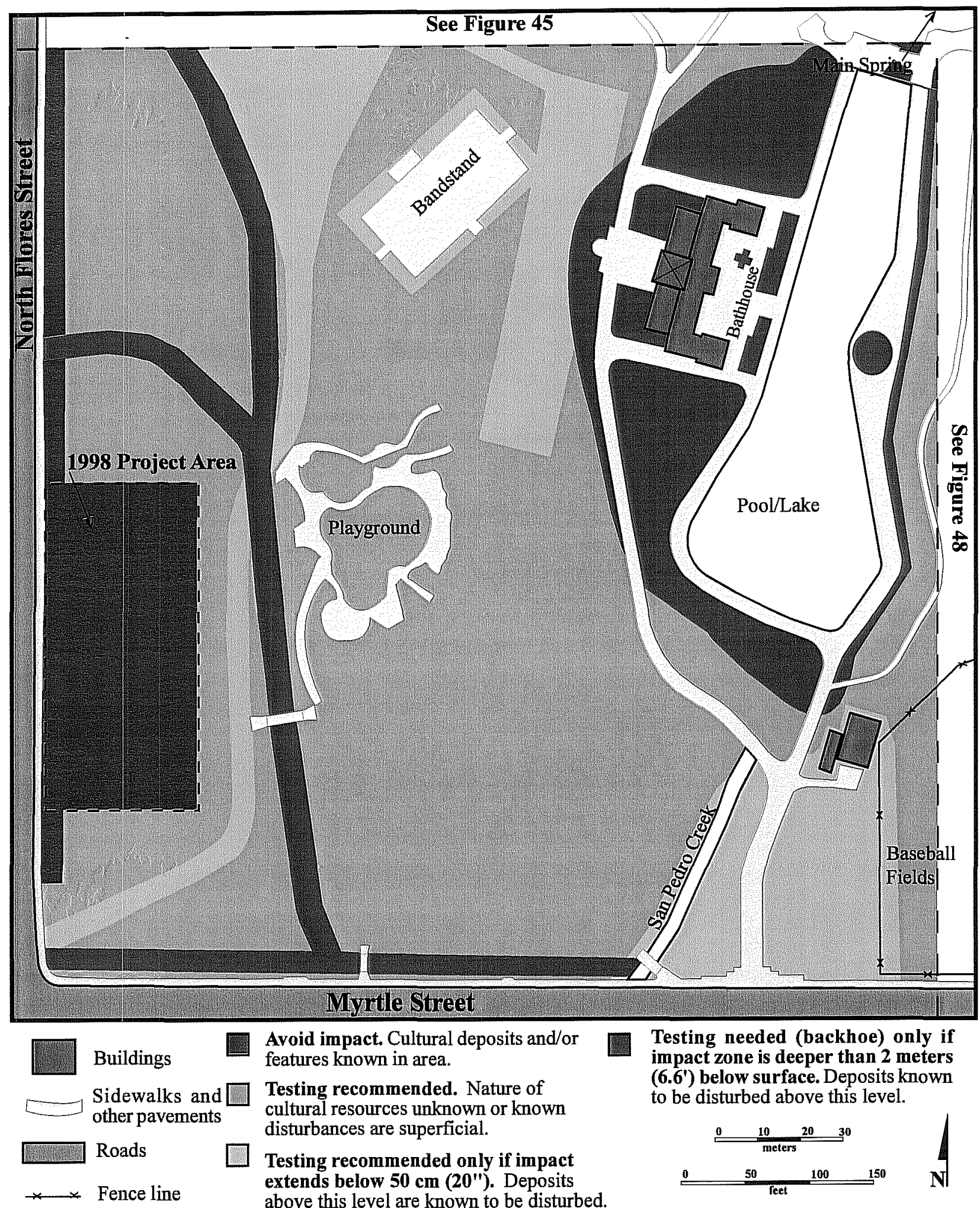

Avoid impact. Cultural deposits and/or features known in area.

Testing recommended. Nature of cultural resources unknown or known disturbances are superficial.

Testing recommended only if impact extends below $50 \mathrm{~cm}\left(20^{\prime \prime}\right)$. Deposits above this level are known to be disturbed.

Testing needed (backhoe) only if impact zone is deeper than 2 meters (6.6') below surface. Deposits known to be disturbed above this level.

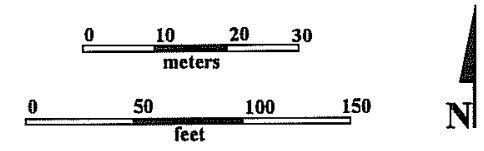

Figure 47. Map of southwest quadrant of San Pedro Park where testing is recommended if impacts are planned. 


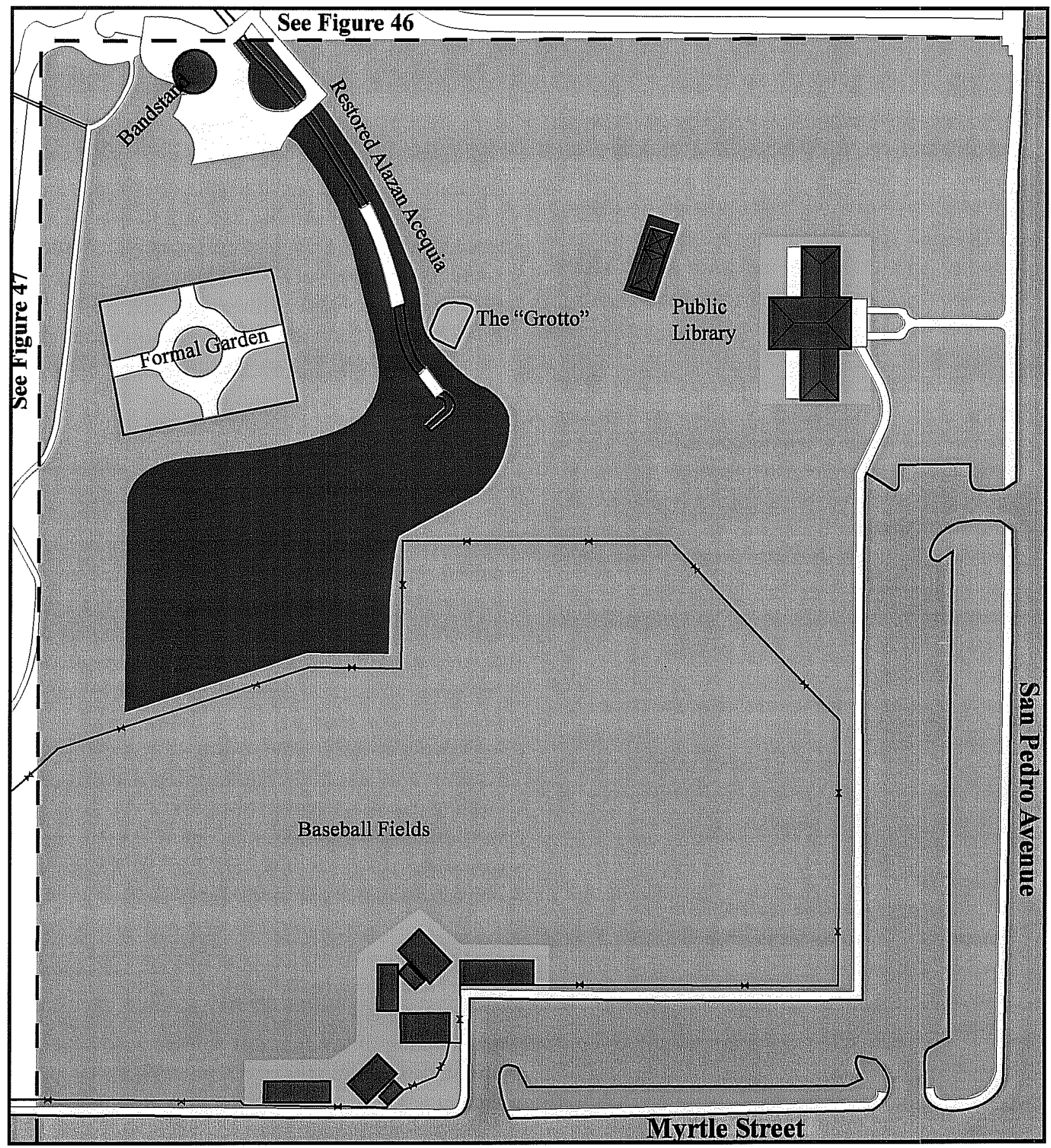

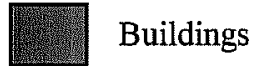

Sidewalks and other pavements

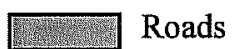

$\leadsto$ Fence line
Avoid impact. Cultural deposits and/or features known in area.

Testing recommended. Nature of cultural resources unknown or known disturbances are superficial.

Testing recommended only if impact extends below $50 \mathrm{~cm}\left(20^{\prime \prime}\right)$. Deposits above this level are known to be disturbed.

Figure 48. Map of southeast quadrant of San Pedro Park where testing is recommended if impacts are planned. 
The cultural resource management recommendations are:

\section{Avoid}

These areas contain known cultural deposits and/or features. Such areas should not be damaged. If impact in the Avoid area cannot be averted, an extensive series of tests, or in some cases, full-scale data recovery, should be conducted, so that features and artifacts within the impact zone can be properly recorded.

\section{Testing}

These are areas where the nature of the cultural deposits to be impacted is unknown. This recommendation is made when little is known about potential archaeological deposits or when the depth of the planned impact is deeper than the known disturbances in the area. Testing needs to be conducted only in the unknown part of the area to be impacted. For instance, if construction of a new building will impact sediments to a depth of 4 feet, monitoring will be needed if the planned impact is in the dark blue zone. However, if the area is in the light blue zone, testing of the lower 28 " $(71 \mathrm{~cm})$ is recommended (see Table 32). In that case, the upper 20 " can be mechanically removed (with monitoring by an archaeologist).

\section{Monitor}

These are areas where the entire area to be impacted is known to be disturbed or when the impact will be less than $3^{\prime}(90 \mathrm{~cm})$. It should be noted, however that small areas of intact deposits might still be present. In the unlikely event that potentially intact deposits are encountered, testing should be performed to evaluate them.

\section{No CRM Procedures Needed}

These are areas where all deposits are known to have been destroyed down to bedrock.

\section{The Northwest Quadrant}

\section{Known Cultural Deposits and/or Features}

The majority of the northwest quadrant of the park has not been tested, and the nature of the cultural deposits, if any, is unknown. The most important feature known to be in the northwest quadrant of the park is the buried remains of the Alazán acequia. In addition, there is an area defined by Houk (1999:23) as Zone 2 . It contains intact prehistoric deposits, although the upper $20 \mathrm{~cm}\left(8^{\prime \prime}\right)$ are disturbed (see Chapter 4, this volume).

\section{Known Disturbances}

The most obvious previous disturbances which occurred in the northwest quadrant are the San Pedro Playhouse, its associated parking lots, and the drainage ditches along the north and western part of the park. The drainage ditches were deep enough to have destroyed all cultural deposits down to bedrock in the northern part of the park. The building can be assumed to have destroyed any deposits to at least $50 \mathrm{~cm}(20 ")$. Exactly how much the parking lots have impacted cultural deposits is not known. The 36" pipe encountered in backhoe trench A, as described in Chapter 3 (see Figure 14), probably runs across the park, but there is no evidence of its exact course.

On the southwestern corner of the quadrant a parking lot has been removed and a drainage ditch filled. The removal of the parking lot and the subsequent filling and leveling of the area can be assumed to have impacted deposits to at least $50 \mathrm{~cm}\left(20^{\prime \prime}\right)$ below current ground level.

\section{Recommended Procedures}

We recommend that any future impacts be avoided in the areas in red on Figure 45. These areas are known to contain historic and prehistoric artifacts and/or features. If an impact cannot be avoided, an extensive series of tests, or in some cases, full-scale excavations, 
should be conducted, so that features and artifacts within the impacted area can be properly recorded.

Future projects in the area where the drainage ditches have been filled will not need testing, as it is known that these ditches have already destroyed all cultural materials. The exception is the filled ditch in the southwestern corner of the quadrant. Test borings in this area (see Figure 6 and Figure 7) suggest that bedrock is deeper in this area, and the ditch may not have destroyed all cultural materials. Backhoe tests should be used in any project in which the impact will be deeper than $183 \mathrm{~cm}\left(6^{\prime}\right)$ in this area.

In the future, any project that will impact the area in green on Figure 45 will require at least some shovel testing and possibly some test units in order to understand the impact that such a project may have on cultural resources.

\section{The Northeast Quadrant}

\section{Known Cultural Deposits and/or Features}

No cultural deposits are known in this quadrant. A small part of the restored Alazán acequia is in the southwestern corner (Figure 46).

\section{Known Disturbances}

The majority of the northeast quadrant of the park has been seriously impacted by the quarrying of limestone (see Chapter 2). These operations, as well as the subsequent development of the McFarlin Tennis Center, has destroyed all deposits down to bedrock. This area is shown in yellow on Figure 46. Very little is known about the area between the springs and the tennis courts. It is likely that the sediments in this area are fill, but testing would be required to prove this, should any project be planned for this portion of the park.

\section{Recommended Procedures}

Testing will be needed if any future projects will impact the area noted in green on Figure 46. This area, immediately around the springs, should not be disturbed. Although it is mostly bare rock, the Alazán acequia was constructed just above the main springs.

\section{The Southwest Quadrant}

\section{Known Cultural Deposits and/or Features}

The southwestern quadrant is the most tested area within San Pedro Park, yet what cultural resources might exist in large areas of this quadrant remain unknown (Figure 47). Chapters 3 and 4 of this volume have shown that a large prehistoric site exists along the western side of the park, and that this site has been seriously impacted by a series of construction activities. This appears to be the only area in this quad where undisturbed cultural deposits are known to exist.

\section{Known Disturbances}

The southwestern quadrant of the park has been subjected to extensive modification and disturbance over the many years of the park's existence. Beginning in the nineteenth century, the area around the natural pool below the main spring had been often modified (see Chapter 2 and Figure 9). Additionally, large drainage ditches were dug along the western and southern edge of the park. Park roads and parking lots were placed, and then recently removed in this quadrant. The placement of a construction staging area over the dense prehistoric deposits in the southwestern portion of this quad, and the resulting damage to the site has been documented in Chapter 4 . These disturbances have significantly impacted cultural deposits in this part of the park, however large areas of the quadrant may have been only superficially disturbed.

\section{Recommended Procedures}

The tested portion of the park, known to contain cultural deposits were identified is shown in red in Figure 47 . We recommend that any future impacts be avoided in these areas. If an impact cannot be avoided, an extensive series of tests, or in some cases, data recovery, should be conducted, so that features and artifacts within the impact area can be properly recorded. As mentioned above, the area in the immediate vicinity of the springs in the northeastern corner of the quadrant should also be avoided. 
The area around the pool is known to have been extensively modified a number of times in the past, and testing by Houk (1999) showed that the entire area is either recent fill or previously disturbed. This area will need testing with a backhoe if future impacts are expected below $183 \mathrm{~cm}\left(6^{\prime}\right)$, as there may be deeply buried deposits. Otherwise, only monitoring is necessary in the area. This is also true in the areas were old drainage ditches have been filled.

The area around the bandstand, the area immediately south of the pond, and the area where previous roads and parking lots have been removed will need to be tested if the expected impact will extend below $50 \mathrm{~cm}$ $\left(20^{\prime \prime}\right)$. Otherwise, monitoring will be acceptable in these areas.

In the rest of this quadrant testing must be performed before any impact that will go below $15 \mathrm{~cm}\left(6^{\prime \prime}\right)$. Much of the previously undisturbed sediments in this quadrant of the park is likely to hold large deposits of prehistoric and possibly historic artifacts and/or features and should be protected.

\section{The Southeast Quadrant}

\section{Known Cultural Deposits and/or Features}

The majority of the restored portion of the Alazán acequia is located in this quadrant. The area to the south and west of the end of the reconstruction is known to have both prehistoric and historic cultural remains both on the surface and buried (see Chapter 3 and Houk 1999:23). This area is marked in red in Figure 48. The Alazán continued from that point toward the southeast corner of the park, exiting just north of that corner (see Figure 8). The extent to which this portion of the acequia still exists is unknown. Also unknown is where the original acequia, begun in 1718 , was located, but there are some indications that it may have been routed through the southeastern part of the park, and there may be remnants still extant underground (I. W. Cox 2000, personal communication).

The small building sometimes called the "Old Fort" or the "Blockhouse" is probably not Spanish Colonial in origin. It is most likely to have been built in the middle of the nineteenth century, or perhaps somewhat earlier (see Chapter 2).

\section{Known Disturbances}

The construction of the baseball parks and the construction of the associated parking lots (Figure 48) probably impacted the cultural deposits in the majority of the southern part of the park. This area was a race course during the nineteenth century (Figure 9). The building of the branch of the San Antonio Public Library may have seriously impacted not only some prehistoric deposits, but the remains of the many concessions and other nineteenth century structures and deposits in the area (see Figure 9).

The building and re-modeling of the formal garden has probably impacted the remains of pavilion shown at that location on old maps (see Figure 9), as well as other cultural resources in the area. The "grotto," where water from one of the springs is used to water a tall concrete form planted with ferns, etc. is just east of the formal garden. Its construction probably disturbed the ground to at least $50 \mathrm{~cm}\left(20^{\prime \prime}\right)$ as well.

The reconstruction of the Alazán acequia also impacted important nineteenth century deposits, but this, fortunately, was recorded by archaeologists (Fox 1979).

\section{Recommended Procedures}

The southeastern quadrant includes a large area that should be avoided if possible. The remains of the Alazán acequia and historic and/or prehistoric deposits are known to be in the area. Impact to the structure of the "Blockhouse" should also be avoided.

The formal gardens and the "grotto" will require testing only if the impact will extend below $50 \mathrm{~cm}\left(20^{\prime \prime}\right)$. This is also true of the area around the library building and the grandstands and other buildings of the baseball park. In the remainder of the southwest quadrant, testing must be performed before any impact that will be deeper than $15 \mathrm{~cm}\left(6^{\prime \prime}\right)$. 


\section{Other Potential Sources of Damage in the Park}

It should be noted that projects planned by the City of San Antonio within the park are not the only source of potential damage to the cultural resources within the park. Natural forces, especially erosion, must be monitored to ensure that cultural resources are protected. Damage caused by public misuse of the park must also be monitored. Prevention of these kinds of damages is an important part of the management of the park. Any projects intended to minimize or repair such damages should be undertaken with the recommendations above in mind.

\section{Recommendations for Increasing Public Awareness}

Although San Pedro Park is one of the most important historic locations in San Antonio, very few of the inhabitants or visitors to the city are aware of this fact. There are not many explanatory signs within the bounds of the park. We recommend that more signage be designed for all areas of the park. These signs should explain:

1) The area has been inhabited for at least 7-8 thousand years;

2) The founding location of Mission San Antonio de Valero (now known as the Alamo) was nearby, probably on the grounds where San Antonio College now stands, northeast of the park. Many of the events of the first 10 years of the Spanish colony took place within or near the park. In addition, the first of the San Antonio acequias began in the park, and the San Pedro and Alazán acequias also ran through the grounds (maps showing the locations of these acequias would probably be of great interest);

3) San Pedro Park is the second oldest dedicated public park in the United States;
4) The first U.S. Army installation in San Antonio was located in the park, just before and during the war with Mexico in 1846-48;

5) San Pedro park was a popular place to spend a Sunday afternoon in the latter part of the nineteenth and early twentieth centuries. There is a considerable number of photographs taken during this period in the collection of the Institute of Texan Cultures (see Figure 10), and at least two old maps of the park that the public would find very interesting; and

6) The entire park is an important archaeological site (41BX19) and is protected by city, state, and federal laws.

Improved understanding of the importance of San Pedro Park by the public will not only increase appreciation of the park, but may make up-keep and improvement projects to the park seem more important to the tax-payers of San Antonio. 


\section{Conclusion}

San Pedro Park represents more than a pleasant public green space within the city (Figure 49). It is an important archaeological site and is protected by law. Whenever a project involving San Pedro Park is planned, the impact of the project on cultural resources within the park must be considered. In this chapter detailed plans for managing the cultural resources of the park were outlined. It is hoped that these strategies will make planning and completion of future projects within the park easier and more efficient for the managers of this important and beautiful resource.

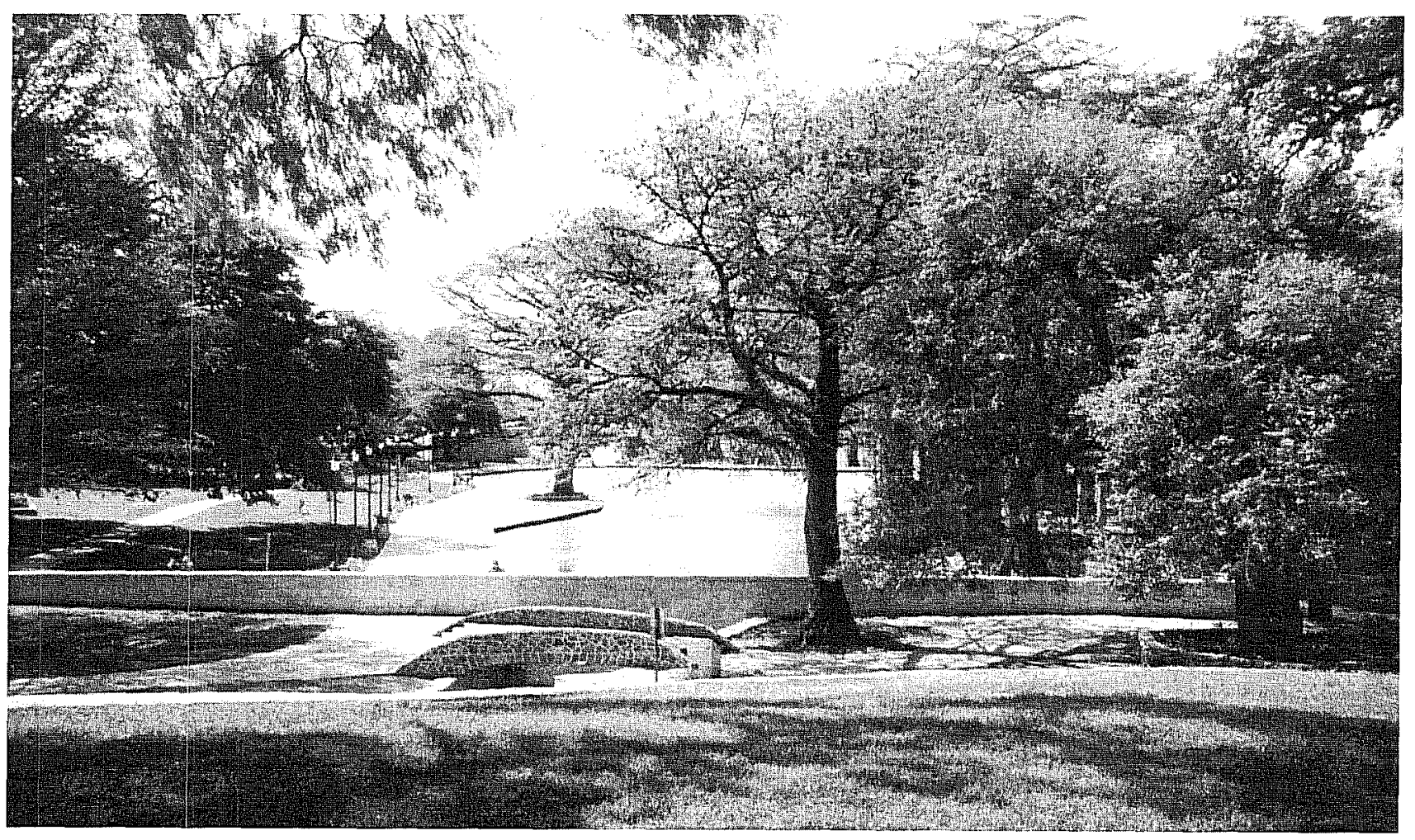

Figure 49. San Pedro Park today, looking south from above the main spring. 


\section{References Cited}

Allen, $\mathrm{P}$.

1993 Questionnaire. San Antonio Express-News, 15 August.

Alamo Express

1860 Governor's Address, 8 October.

Balkwill, D. M. and S. L. Cumbaa

1992 A Guide to the Identification of Postcranial Bones of Bos taurus and Bison bison. Canadian Museum of Nature, Ottawa.

Barnes, V. E.

1974 Geologic Atlas of Texas: San Antonio Sheet. Bureau of Economic Geology, The University of Texas at Austin.

Bartlett, J. R.

1965 Personal Narrative of the Expedition and Incidents Connected with the United States and Mexican Border Commission. Two Volumes. Originally published 1854, reprinted Rio Grande Press, Chicago.

Bauer, K. J.

1974 The Mexican War; 1846-1848. Macmillan, New York.

Black, S. L.

1989 Central Texas Plateau Prairie. In From the Gulf Coast to the Rio Grande: Human Adaptation in Central, South and Lower Pecos Texas, edited by T. R. Hester, S. L. Black, D. G. Steele, B. W. Olive, A.A. Fox, K. J. Reinhard, and L. C. Bement, pp. 17-38. Research Series No. 33. Arkansas Archeological Survey, Fayetteville.

1995 Archaeological and Historical Background. In Archaeological Investigations at the Loma Sandia Site (41LK28): A Prehistoric Campsite in Live Oak County, Texas. 2 Volumes. Studies in Archeology No. 20, pp. 31-45. Texas Archeological Research Laboratory, The University of Texas at Austin.

Blair, W. F.

1950 The Biotic Provinces of Texas. Texas Journal of Science. 1(1):93-117.

Boessneck, J.

1970 Osteological Differences Between Sheep (Ovis aries Linné) and Goats (Capra hircus Linné). In Science in Archaeology, edited by D. Brothwell and E. Higgs, pp. 331-358. Praeger, New York.

Bousman, C. B.

1994 The Central Texas Pollen Record: A Reinterpretation. Current Research in the Pleistocene 11:79-81.

1998 Paleoenvironmental Change in Central Texas: The Palynological Evidence. Plains Anthropologist (43) 164:201-219. 
Brune, G.

1981 Springs of Texas. Vol. 1. Branch-Smith, Fort Worth.

Bryant, V. M., and R. G. Holloway

1985 Late Quaternary Paleoenvironmental Record of Texas. In Pollen Records of Late-Quaternary North American Sediments, edited by V.M. Bryant and R.G. Holloway, pp.39-70. American Association of Stratigraphic Palynologists Foundations, Austin.

Bryant, V. M., and H. J. Shafer

1977 The Late Quaternary Paleoenvironment of Texas: A Model for the Archaeologist. Bulletin of the Texas Archeological Society 48:1?25.

Campbell, T. N.

1975 The Payaya Indians of Southern Texas. Special Publications No. 1. Southern Texas Archaeological Association, San Antonio.

Campbell, T. N., and T. J. Campbell

1985 Indian Groups Associated with Spanish Missions of the San Antonio Missions National Historical Park. Special Report, No. 16. Center for Archaeological Research, The University of Texas at San Antonio.

Chabot, F. C.

1937 With the Makers of San Antonio. Artes Gráficas, San Antonio.

Chapman, R. C., and J. A. Schutt

1977 Methodology of Lithic Analysis. In Archaeological Investigations in Cochiti Reservoir, New Mexico (Vol. 2), Excavation and Analysis, 1975 Season, edited by R. Chapman and J. Biella, pp. 83-96. Office of Contract Archaeology, The University of New Mexico at Albuquerque.

Chipman, D. E.

1992 Spanish Texas, 1519-1821. University of Texas Press, Austin.

Clark, D. L.

1968 Analytical Archaeology. Metheun, London.

Collins, M. B.

1995 Forty Years of Archeology in Central Texas. Bulletin of the Texas Archeological Society. 66:361-400.

Collins, M. B., C. B. Bousman, P. Goldberg, J. Guy, P. Takac, T. Staford, and V. Holliday.

1993 The Paleoindian Sequence at the Wilson-Leonard Site, Texas. Current Research in the Pleistocene 10:10-12.

Corner, W.

1890 San Antonio de Bexar: A Guide and History. Bainbridge and Corner, San Antonio. 
Cox, I. W.

1986 Excavation of Portions of the San Pedro Acequia (41BX337) and a Search for the Arocha Acequia, San Antonio, Texas. Archaeological Survey Report No. 161. Center for Archaeological Research, The University of Texas at San Antonio.

1987 Planning Document (Phase I) for Archaeological Investigations at Proposed Development at San Pedro Park. Letter Report, Center for Archaeological Research, The University of Texas at San Antonio.

Crook, C. E.

1967 San Pedro Springs Park, Texas Oldest Recreation Area. Privately printed, San Antonio.

Cutrer, T. W.

1996 Harney, William Selby. In The New Handbook of Texas, edited by R. Tyler. Texas State Historical Association, Austin.

Dial, S. W.

1992 Ceramics. In Archaeological Investigations in Alamo Plaza, San Antonio, Bexar County Texas: 1988 and 1989, edited by A. A. Fox, pp. 29-46. Archaeological Survey Report, No. 205. Center for Archaeological Research, The University of Texas at San Antonio.

Ellis, L. W., G. L. Ellis, and C. D. Fredrick

1995 Implications of Environmental Diversity in the Central Texas Archeological Region. Bulletin of the Texas Archeological Society 66:401-426.

Flenniken, J. and J. Haggerty

1979 Trampling as an Agent in the Formation of Edge Damage: An Experiment in Lithic Technology. Northwest Anthropological Research Notes 13:208-214.

Foster, W. C.

1995 Spanish Expeditions into Texas, 1689? 1768. University of Texas Press, Austin.

Foster, W. C., and J. Jackson (editors)

1993 The 1693 Expedition of Governor Salinas Varona to Sustain the Missionaries Among the Tejas Indians. Translated by N. F. Brierly. Southwestern Historical Quarterly 97:264-311.

Fox, A. A.

1975 An Archaeological Assessment of the Southern Portion of the Olmos Basin, Bexar County, Texas. Archaeological Survey Report, No. 9. Center for Archaeological Research, The University of Texas at San Antonio.

1978 Archaeological Investigations of Portions of the San Pedro and Alazán Acequias in San Antonio, Texas. Archaeological Survey Report, No. 49. Center for Archaeological Research, The University of Texas at San Antonio.

1979 A Survey of Archaeological, Architectural and Historical Sites on the San Antonio River, from Olmos Dam to South Alamo Street and on San Pedro Creek from San Pedro Park to Guadalupe Street. Archaeological Survey Report, No. 80. Center for Archaeological Research, The University of Texas at San Antonio. 
Fox, A. A., F. A. Bass, Jr., and T. R. Hester

1976 The Archaeology and History of Alamo Plaza. Archaeological Survey Report, No. 16. Center for Archaeological Research, The University of Texas at San Antonio.

Gifford-Gonzalez, D. P., D.B. Damrosch, D. R. Damrosch, J. Pryor, and R.L. Thunen

1985 The Third Dimension in Site Structure: An Experiment in Trampling and Vertical Dispersal. American Antiquity 50:803-818.

Gilbert, B. M.

1990 Mammalian Osteology. Missouri Archaeological Society, Columbia, Missouri.

Goddard, I.

1979 The Languages of South Texas and the Lower Rio Grande. In The Languages of Native America: Historical and Comparative Assessments, edited by Campbell and M. Mithun, pp. 355?389. University of Texas Press, Austin.

Gould, S.

1882 The Alamo City Guide: San Antonio, Texas; Being a Historical Sketch of the Ancient City of the Alamo and Business Review. Macgowan and Slipper, New York.

Gunn, J., D. O. Brown, A. A. Fox, A. Frkuska, and D. Watkins, III

1982 Historic and Cultural Landscape Study for the San Antonio Missions. Environmental and Cultural Services, San Antonio.

Gunn, J., and R. Mahula

1977 Hop Hill: Culture and Climatic Change in Central Texas. Special Report, No. 5. Center for Archaeological Research, The University of Texas at San Antonio.

Haberman, S. J.

1973 The Analysis of Residuals in Cross-Classified Tables. Biometrics 29:205-220.

Hard, R. J., A. A. Fox, I. W. Cox, K. J. Gross, B. A. Meissner, G. Mendez, C. L. Tennis, and J. Zapata 1995 Excavations at Mission San Jose y Miguel de Aguayo, San Antonio, Texas. Archaeological Survey Report, No. 218. Center for Archaeological Research, The University of Texas at San Antonio.

Harpur, P. (editor)

1982 The Timetable of Technology: A Record of the 20th Century's Amazing Achievements. Hearst, New York.

Hatcher, M. A. (translator)

1932 The Expedition of Don Domingo Teran de Los Rios into Texas. Preliminary Studies of the Texas Catholic Historical Society 2(1):20-78.

Hester, T. R.

1995 The Prehistory of South Texas. Bulletin of the Texas Archeological Society 66:427-459. 
Highley, C. L.

1995 Chipped Stones. In Archeological Investigations at the Loma Sansia Site (41LK28): A Prehistoric Cemetery and Campsite in Live Oak County, Texas, by A. J. Taylor and C. L. Highley, pp. 405-484. Studies in Archeology, No. 20. Texas Archeological Research Laboratory, The University of Texas at Austin.

Hildebrand, $M$.

1955 Skeletal Differences Between Deer, Sheep, and Goats. California Fish and Game 41:327-346.

Hillson, Simon

1986 Teeth. Cambridge University Press, Cambridge.

Hoffman, F. L. (translator)

1935 Diary of the Alarcán Expedition into Texas, 1718-1719. Quivira Society Publications, Volume 5, reprinted, Arno Press, New York.

1938 The Mesquía Diary of the Alarcón Expedition into Texas, 1718. Southwestern Historical Quarterly, XLI:312-323.

Houk, B. A.

1999 Archaeological Survey and Testing in San Pedro Park (41BX19), San Antonio, Texas. Archaeological Survey Report, No. 289. Center for Archaeological Research, The University of Texas at San Antonio.

Hulbert, R. C.

1985 Vertebrate Faunal Remains. In The Panther Springs Creek Site: Cultural Change and Continuity within the Upper Salado Creek Watershed, South-Central Texas, by S. L. Black and A. J. McGraw, pp. 209?215. Archaeological Survey Report, No. 100. Center for Archaeological Research, The University of Texas at San Antonio.

Hunziker, J. M., B. A. Meissner, S. A. Tomka, and T. K. Perttula

1997 Culture Histories and Their Use in the Archaeology of the Rio Grande Plains and the Central Coastal Plains. In Archaeology of the Rio Grande and Central Coastal Plains, Texas: A Planning Document, by S. A. Tomka, T. K. Perttula, and R. J. Hard. Archaeological Survey Report, No. 266. Center for Archaeological Research, The University of Texas at San Antonio. Review draft.

Ivey, J. E., and A. A. Fox

1981 Archaeological Survey and Testing at Rancho de las Cabras, Wilson County, Texas. Archaeological Survey Report, No. 104. Center for Archaeological Research, The University of Texas at San Antonio.

Inglis, J. M.

1964 A History of Vegetation on the Rio Grande Plain. Bulletin No. 45. Texas Parks and Wildlife Department, Austin.

Jelinek, Arthur J.

1966 Some Distinctive Flakes and Flake Tools from the Llano Estacado. Papers of the Michigan Academy of Science, Arts and Letters. Vol. LI. pp. 399-405. 
Johnson, E.

1985 Current Developments in Bone Technology. In Advances in Archaeological Method and Theory, Volume 8, edited by M. B. Schiffer, pp. 157-235. Academic Press, Orlando, FL.

Labadie, J. H.

1987 An Archaeological and Historical Assessment of the Vista Verde South Project, San Antonio, Texas. Archaeological Survey Report, No. 156. Center for Archaeological Research, The University of Texas at San Antonio.

Logan, H. C.

1959 Cartridges: A Pictorial Digest of Small Arms Ammunition. Bonanza, New York.

Loomis, L. E., W. F. Gabriel, and B. R. Brasher

1992 Genesis of the Quihi Soil in the Uvalde Gravel of South-Central Texas. In Preliminary Draft of Late Cenozoic Alluvial Stratigraphy and Prehistory of the Inner Gulf Coastal Plain, South-Central Texas. Guidebook, 10th Annual Meeting, South-Central Friends of the Pleistocene. Lubbock Lake Landmark Quaternary Research Center Series 4:47-72.

Lyman, R. L.

1994 Vertebrate Taphonomy. Cambridge University Press, Cambridge.

Mallouf, R. J.

1981 A Case Study of Plow Damage to Chert Artifacts: The Broken Creek Cache, Hill County, Texas. Office of the State Archeologist, Report 33. Texas Historical Commission, Austin.

Mauldin, R. P., and D. S. Amick

1989 Investigating Patterning in Debitage from Experimental Bifacial Core Reduction. In Experiments in Lithic Technology, edited by D. Amick and R. Mauldin, pp. 67-88. BAR International Series 528. Oxford.

McBrearty, S., L. Bishop, T. Plummer, R. Dewar and N. Conrad

1998 Tools Underfoot: Human Trampling as an Agent of Lithic Artifact Edge Modification. American Antiquity 63:108-130.

Meissner, B. A.

1996 The Alamo Restoration and Conservation Project, Excavations at the South Transept. Archaeological Survey Report No. 245, Center for Archaeological Research, The University of Texas at San Antonio.

1997 Dolls, Toys, Games, and other Diversions. In Archaeology at the Alamodome: Investigations of a San Antonio Neighborhood in Transition, Volume III: Artifact and Special Studies, edited by A. A. Fox, M. Renner, and R. J. Hard, pp.57-99.Archaeological Survey Report No. 238,Center for Archaeological Research, The University of Texas at San Antonio.

1998a Faunal Remains. In 41MV120: A Stratified Late Archaic Site in Maverick County, Texas, by B. J. Vierra, pp.182-183. Archaeological Survey Report No. 251, Center for Archaeological Research, The University of Texas at San Antonio and Archeology Studies Program No. 7, Environmental Affairs Division, Texas Department of Transportation, Austin. 
Meissner, B. A., D. A. Cargill, and D. L. Nickels

1998 Vertebrate Faunal Remains and Fish Otoliths. In Test Excavations at the Culebra Creek Site, 41BX126, San Antonio, Texas, by D. L. Nickels C. B. Bousman, J. D. Leach, and D. A. Cargill, pp. 195-203. Archaeological Survey Report No. 265, Center for Archaeological Research, The University of Texas at San Antonio and Archeology Studies Program No. 3, Environmental Affairs Division, Texas Department of Transportation, Austin.

Mitchell, J. L.

1976 A Tentative New Type of Late Paleo-Indian Point from South Texas. La Tierra, the Journal of the Southern Texas Archaeological Association 3(1):20-22.

Munsey, C.

1970 The Illustrated Guide to Collecting Bottles. Hawthorn, New York.

Nickels, D. L.

1998 Setting. In Test Excavations at the Culebra Creek Site, 41BX126, San Antonio, Texas, pp. 4-18, edited by D.L. Nickels and C. B. Bousman. Archeology Studies Program, Report 3, Environmental Affairs Division, Texas Department of Transportation. Archaeological Survey Report, No. 265. Center for Archaeological Research, The University of Texas at San Antonio.

Nickels, D. L., and I. W. Cox

1996 An Archaeological Assessment of the Alazan Acequia (41BX620) in the Five Points Area of San Antonio, Bexar County, Texas. Archaeological Survey Report, No. 253. Center for Archaeological Research, The University of Texas at San Antonio.

Nickels, D. L., D. W. Pease, and C. B. Bousman

1997 Archaeological Survey of Lackland Air Force Base, Bexar County, Texas. Archaeological Survey Report, No. 248. Center for Archaeological Research, The University of Texas at San Antonio.

Nielsen, A. E.

1991 Trampling the Archaeological Record: An Experimental Study. American Antiquity 56:483-503.

Norwine, J.

1995 The Regional Climate of South Texas: Patterns and Trends. In The Changing Climate of Texas: Predictability and Implications for the Future, edited by J. Norwine, J. R. Giardino, G. R. North and J. B. Valdez, pp. 138?154. Cartographics, Texas A\&M University. College Station, Texas.

Olsen, Stanley J.

1960 Post-Cranial Skeletal Characters of Bison and Bos. Peabody Museum, Cambridge, MA.

1964 Mammal Remains from Archaeological Sites Part I; Southeastern and Southwestern United States. Peabody Museum, Cambridge.

1968 Fish, Amphibian, and Reptile Remains from Archaeological Sites Part I: Southeastern and Southwestern United States. Peabody Museum, Cambridge.

Orchard, C. D., and T. N. Campbell

1954 Evidences of Early Man from the Vicinity of San Antonio, Texas. Texas Journal of Science 6(4):454465.

1960 Southwestern Pottery from Sites in the Vicinity of San Antonio, Texas. Texas Archaeology 4(2):7-8. 
Patterson, L. W.

1979 Quantitative Characteristics of Debitage from Heat Treated Chert. Plains Anthropologist 24:255-259.

Peyton, G.

1946 San Antonio, City in the Sun. McGraw-Hill, New York.

Pool, J. C.

1987 Fanthorp Inn: A Study of Nineteenth and Twentieth Century Buttons. In Archeological Excavations at Fanthorp Inn State Historic Site (41GM79), Grimes County, Texas, Spring and Fall 1982, by J. D. Ing and J. Hart, pp. 277-290. Texas Parks and Wildlife Department, Historic Sites and Restoration Branch, Austin.

Potter, D. R., S. L. Black, and K. Jolly

1995 Archeology Along the Wurzbach Parkway. Module 1: Introduction, Conceptual Framework, and Contexts of Archeological Investigations in Bexar County, South-Central Texas. Studies in Archeology No. 17. Texas Archeological Research Laboratory, The University of Texas at Austin.

Potter, D. R., C. K. Chandler, and E. Newcomb

1992 Archaeological Salvage Research at 41BX901, a Prehistoric Quarry in Bexar County, Texas. Archaeological Survey Report, No. 211. Center for Archaeological Research, The University of Texas at San Antonio.

Prentiss, W.C. and E. J. Romanoski

1989 Experimental Evaluation of Sullivan and Rozen's Debitage Typology. In Experiments in Lithic Technology, edited by D. Amick and R. Mauldin, pp. 89-100. BAR International Series 528. Oxford.

Pryor, J. H.

1988 The Effects of Human Trample Damage on Lithics: A Model of Crucial Variables. Lithic Technology 17:45-50.

Purdy, B. A.

1974 Investigations Concerning The Thermal Alteration of Silica Minerals: An Archaeological Approach. Tebiwa: 17:37-66.

Randall, M. E.

1971 Early Marbles. Historical Archaeology 5:102-105.

Ray, M.

1974 Collectible Ceramics: An Encyclopedia of Pottery and Porcelain for the American Collector. Crown, New York

Rice, $P$.

1987 Pottery Analysis: A Source Book. University of Chicago Press, Chicago.

Ricklis, R. A.

1996 The Karankawa Indians of Texas: An Ecological Study of Cultural Tradition and Change. University of Texas Press, Austin. 
Rodriguez, J. M.

1961[1913] Rodriguez Memoirs of Early Texas. Passing Show Press. Standard, San Antonio.

Roper, D. C.

1976 Lateral Displacement of Artifacts due to Plowing. American Antiquity 41: 372-375.

San Antonio Express

1875 Ditch Contract Work, 17 April.

1875 Report of the Public Improvements Committee Upon the Upper Labor Ditch Contract Work, 5 May.

1900 San Pedro Park Improvements Complete, 17 March.

1900 San Pedro Park. 18 March.

San Antonio Express-News

1986 Antonio Little Theater. 21 September.

San Antonio Light

1885 Park Improvements, 5 May.

1915 Large Canal in Park May Avert Floods, 17 January.

1949 The Zoo. 3 July.

Schmid, E.

1972 Atlas of Animal Bones for Prehistorians, Archaeologists, and Quaternary Geologists (Knochenatlas Für Prähistoriker, Archäologen und Quartärgeologen). Elsevier Publishing, Amsterdam.

Shafer, H. J.

1970 Notes on Uniface Retouch Technology. American Antiquity 35(45):480-487.

Shaffer, B. S.

1995 Analysis of Vertebrate Fauna. In Past Cultures and Climates at Jonas Terrace, 41ME29, Medina County, Texas, by L. Johnson, pp. 306-325. Report No. 40. Office of the State Archeologist, Texas Department of Transportation and Texas Historical Commission, Austin.

Smith, B. (translator)

1966[1871] Relation of Alvar Nuñez Cabeza de Vaca. Privately printed, New York. Reprinted by University Microfilms.

Smith, J. H.

1963[1919] The War With Mexico, Two Volumes. Peter Smith, Gloucester, Massachusetts.

Stahl, D. W., and M. K. Cleaveland

1993 Southern Oscillation Extremes Reconstructed from Tree Rings of the Sierra Madre Occidental and Southern Great Plains. Journal of Climate 6:129-140.

1995 Texas Paleoclimate Data From Daily To Millennial Time Scales. In The Changing Climate of Texas: Predictability and Implications for the Future, by J. Norwine, J. R. Giardino, G. R. North and J. B. Valdez, pp. 49?69. Cartographics, Texas A\&M University. College Station, Texas. 
Steinfeldt, C.

1978 San Antonio Was: Seen Through a Magic Lantern. San Antonio Museum Association, San Antonio.

Sullivan, A. P. and K. C. Rozen

1985 Debitage Analysis and Archaeological Interpretation. American Antiquity 50:755-779.

Taylor, F. B., R. B. Hailey, and D. L. Richmond

1991 Soil Survey of Bexar County, Texas. United States Department of Agriculture, Soil Conservation Service.

Texas Supreme Court

1857 Reports of Cases Heard and Decided, "Lewis, et al. v. City of San Antonio." Report Number 7, Texas Reports.

Thoms, A. V., D. D. Kuehn, B. W. Olive, J. E. Dockall, P. A. Clabaugh, and R. D. Mandel

1996 Early and Middle Holocene Occupations at the Richard Beene Site: The 1995 Southern Texas Archaeological Association Field School Project. La Tierra 23(4):8.36.

Tomka, S. A.

1989 Differentiating Lithic Reduction Techniques: An Experimental Approach. In Experiments in Lithic Technology, edited by D. Amick and R. Mauldin, pp. 137-162. BAR International Series 528. Oxford.

Tomka, S. A., C. B. Bousman, and J. M. Hunziker

1997a Modern and Paleoenvironmental Context. In Archaeology of the Rio Grande and Central Coastal Plains, Texas: A Planning Document, edited by S. A. Tomka, T. K. Pertulla, and R. J. Hard. Archaeological Survey Report, No. 266. Center for Archaeological Research, The University of Texas at San Antonio.

Tomka, S. A., A. A. Fox, and B. A. Meissner

1999 Vertebrate Faunal Remains. In Mission San José, Repointing and Underpinning Project, San Antonio, Texas. Archaeological Survey Report, No. 294. Center for Archaeological Research, The University of Texas at San Antonio.

Tomka, S. A., B. A. Meissner, and T. K. Pertulla

1997b Hunter-gatherer Subsistence Practices. In Archaeology of the Rio Grande and Central Coastal Plains, Texas: A Planning Document, by S. A. Tomka, T. K. Pertulla, and R. J. Hard. Archaeological Survey Report, No. 266. Center for Archaeological Research, The University of Texas at San Antonio.

Toulouse, J. H.

1971 Bottle Makers and Their Marks. Thomas Nelson, New York.

Tous, G. (translator)

1930 The Espinosa-Olivares-Aguirre Expedition of 1709. Preliminary Studies of the Texas Catholic Historical Society, I (III).

Turner, E. S., and T. R. Hester

1993 A Field Guide to Stone Artifacts of Texas Indians. Second Edition. Gulf, Houston. 
Uecker, H. G.

1991 Archival and Historical Research for the San Pedro Creek Channel Improvement Project: The 19891990 Investigations. Archaeological Survey Report, No. 199. Center for Archaeological Research, The University of Texas at San Antonio.

1992 Lithic Artifacts. In Archaeological Investigations in Alamo Plaza, San Antonio, Bexar County, Texas, 1988 and 1989, edited by A. A. Fox, pp. 64-74. Archaeological Survey Report, No. 205. Center for Archaeological Research, The University of Texas at San Antonio.

War of the Rebellion

1901 The War of the Rebellion, A Compilation of the Official Records of the Union and Confederate Armies. Volumes, Government Printing Office, Washington.

Weniger, D.

1997 The Explorers' Texas. Vol. 2: The Animals They Found. Eakin Press, Austin

Whittaker, J. C.

1994 Flintknapping: Making and Understanding Stone Tools. University of Texas Press, Austin.

Woolford, S. W.

1935 Types of Archaeological Sites Found in Bexar County. Paper presented at the meeting of the Southwest Texas Archaeological Society and the Texas Science Club, and printed by the Witte Memorial Museum, San Antonio, Texas 



\section{Appendix A}

Artifact Data

from 1996 Testing 


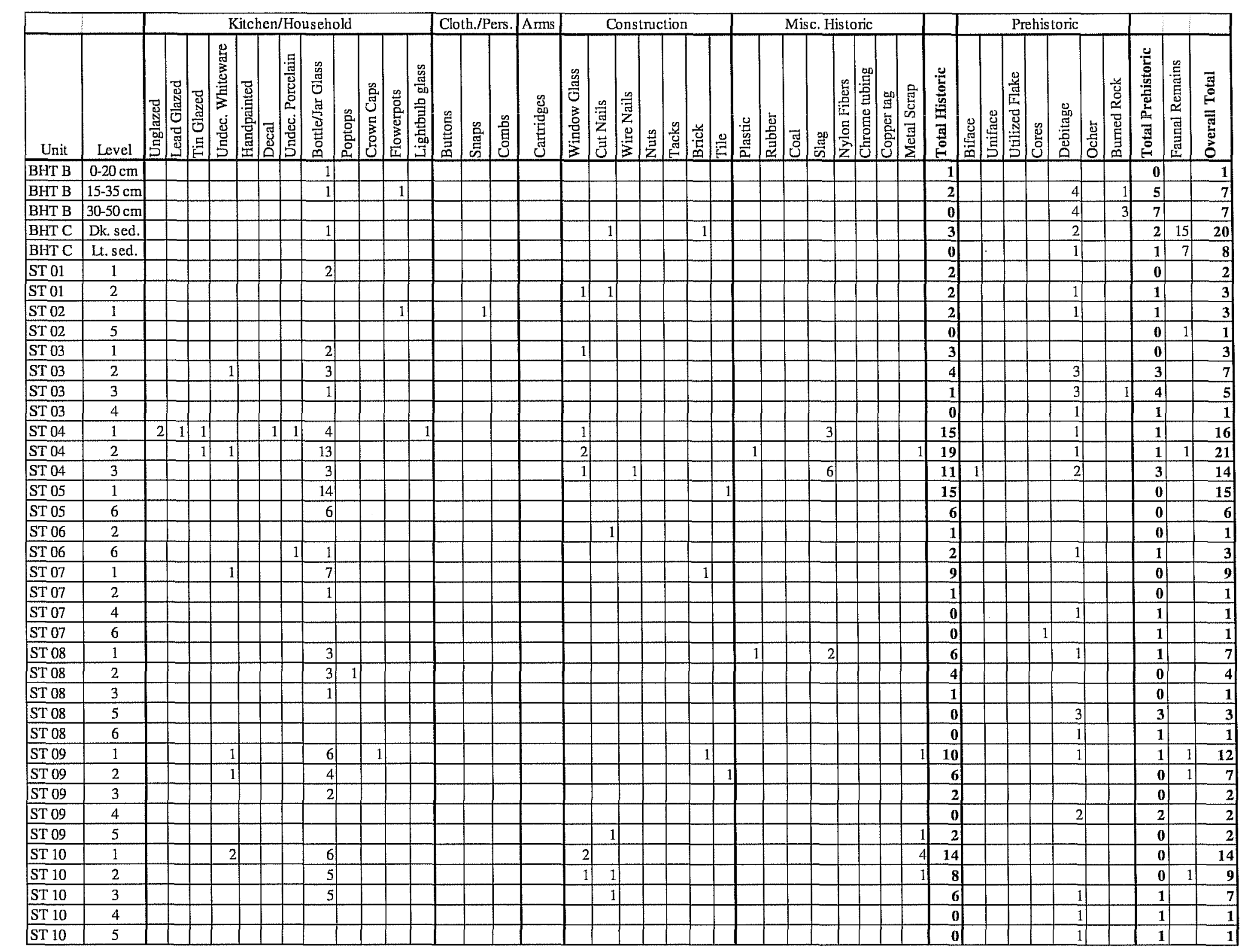




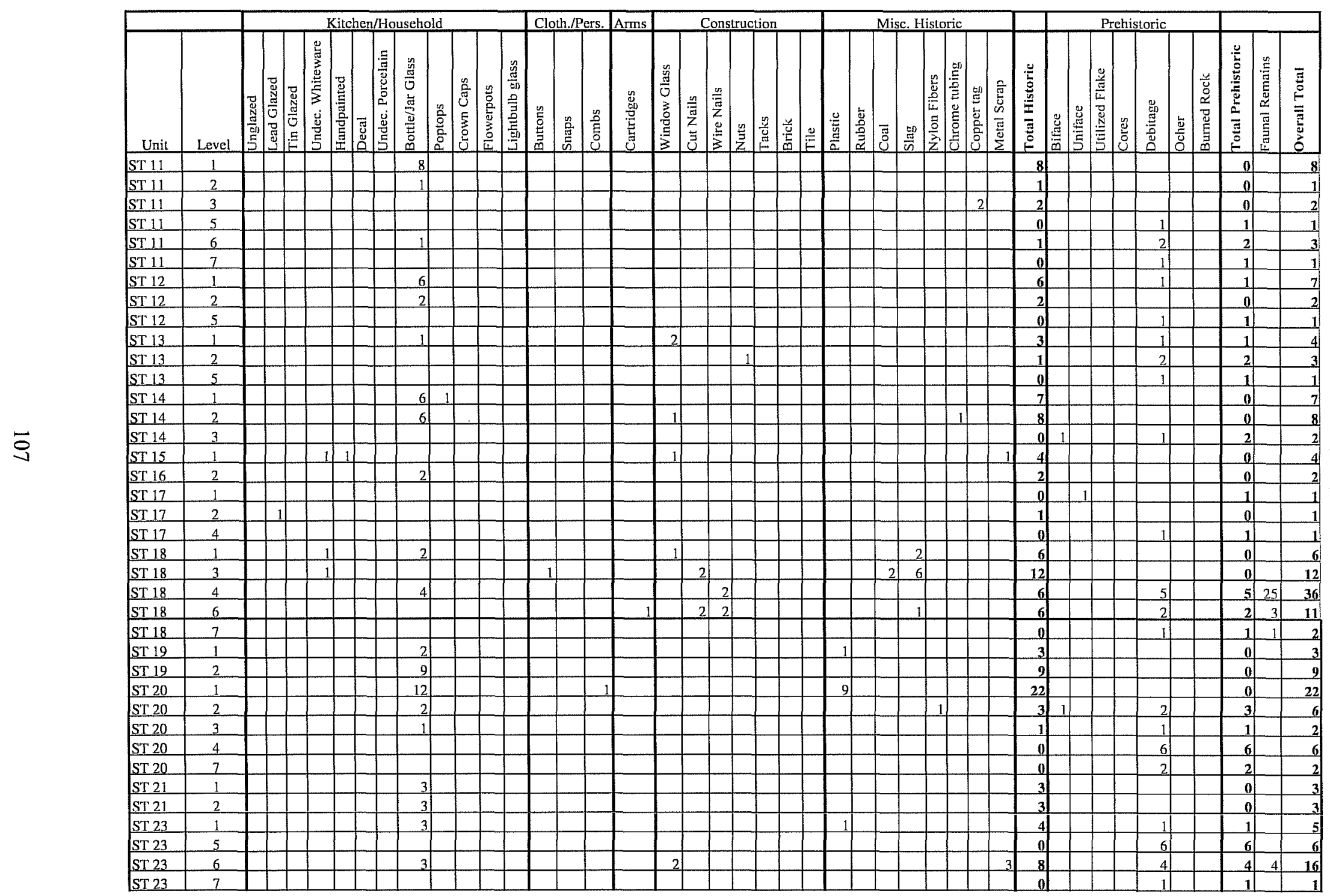




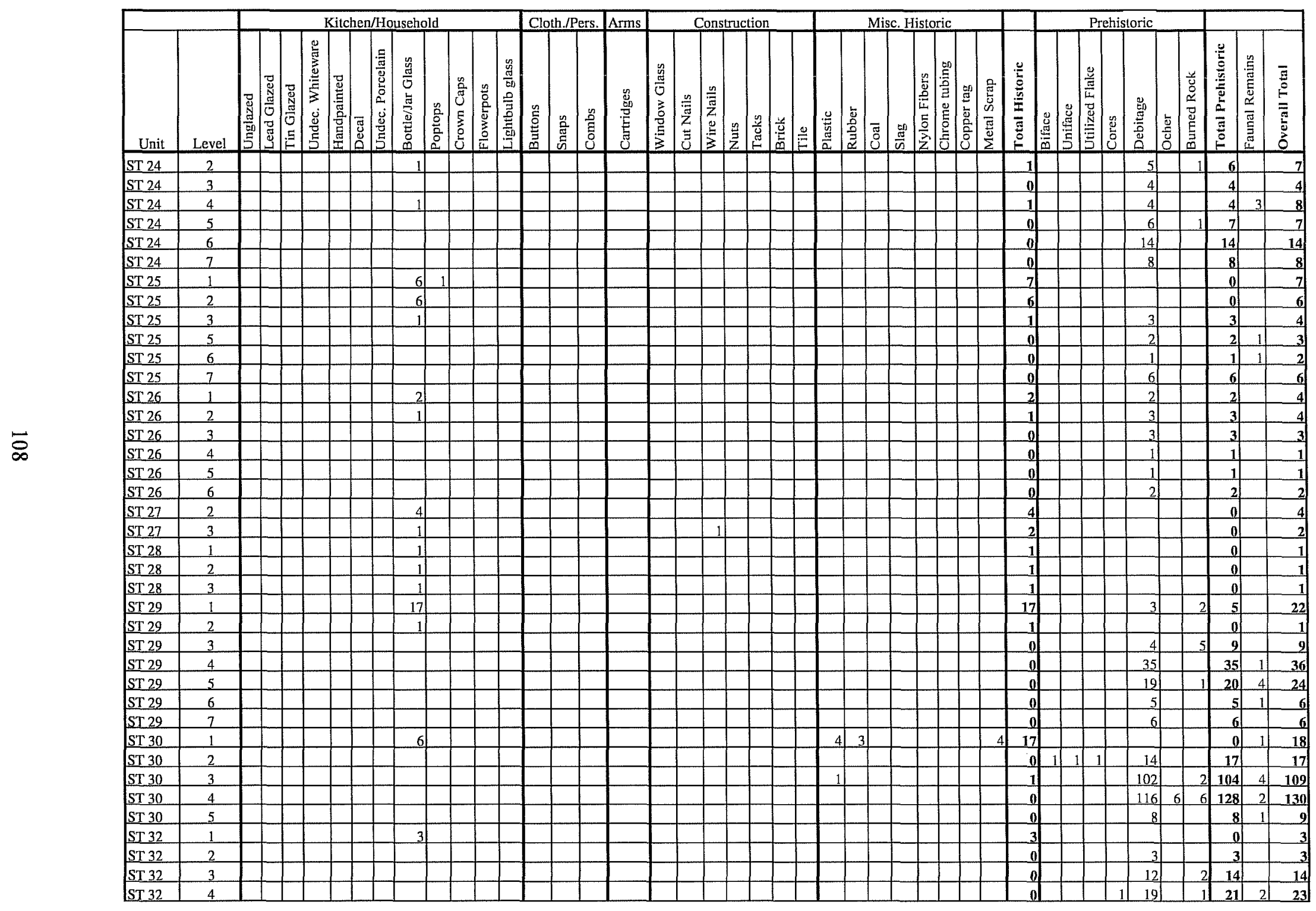




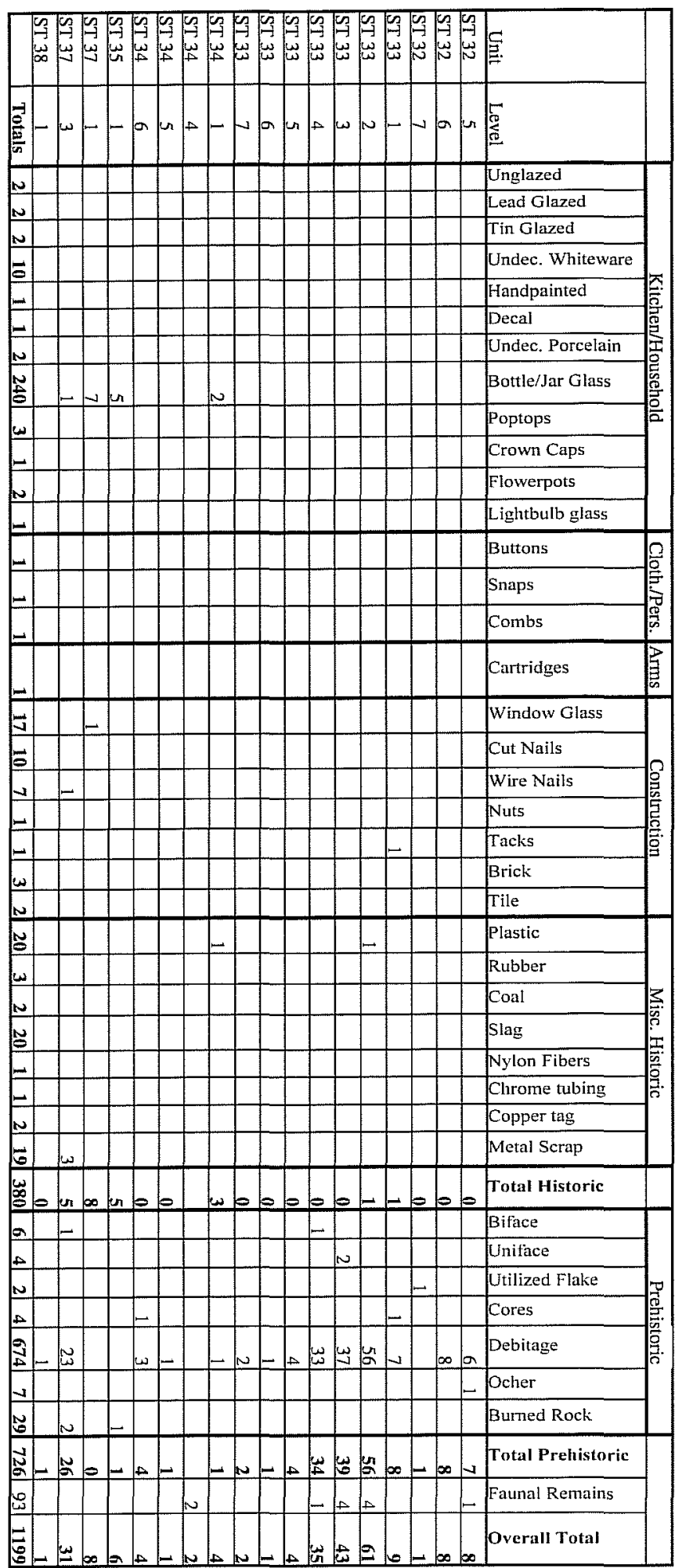



Appendix B

Faunal Data

from 1996 Testing 


\begin{tabular}{|c|c|c|c|c|c|c|c|c|c|c|c|}
\hline Unit & Lev. & C. & Wet. (g) & Taxon & Element & Side & Portion & Butcher Marks & Burned? & Juv.? & Comments \\
\hline BHTC C & Dk. & 1 & 40.27 & 7 Equus caballos & Tooth (Unper nermanenL 1. 1sL molar) & $\mathrm{L}$ & Complete & & & & \\
\hline BHTC & $\mathrm{Dk}$. & 1 & 15.87 & 7 Bos taurus & 2nd Phalengec & & Complete & & & Ycs & Proximal cpiphysis is unscalcd \\
\hline BHTC C & $\mathrm{Dk}$ & 1 & 0.55 & Crotulus atrox & Vertebra & & Completc & & & & \\
\hline BHTC C & $D k$. & 1 & 3.25 & 5 Odocoileus virginianus & Toolh (Upper permanent 2nd moler) & $\mathrm{L}$ & No buccal surfacc & & & & \\
\hline BHTC C & Dk. & 1 & 0.50 & odocoileus virginiamus & Tooth (Lower deciduous premolar & $\mathrm{L}$ & No root & & & & \\
\hline BHTC & $\mathrm{Dk}$. & 1 & 1.50 & of Small Artidaclyl & Lumbar vertc bra & & Frapmenl & & & & \\
\hline BHTC C & $D k$. & 2 & 15.55 & Small Aridactyl & Humcrus & $\mathrm{L}$ & Fragment of the diaphysis & & & & Broken while fresh and while dry \\
\hline BHT C & Dk. & 1 & 1.13 & 3 Small Artidacty] & Verlehra & 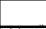 & Fragmenl or cenlrim & & & Yes & Both epinhyses are unsenled \\
\hline BHTC & Dk. & 5 & 3.13 & Mammal & & & & & & & \\
\hline BHTC C & Dk. & 1 & 0.85 & Sciumus cf niger & Cranium & & Fragmenl o[ occinilal & & & & \\
\hline BHTC & LL & 1 & $\frac{3.15}{3.15}$ & 5 Sus scrofa & Tibia & $\mathrm{L}$ & Frapment of distal end & & & & Surface is heavily pilled \\
\hline BHTC C & L. & 1 & 1.87 & 7 Capra/Ovis & Calcancum & $\mathrm{L}$ & Distal cpiphysis & & & Yes & Surfacc is pilted, epinhysis is unsealed \\
\hline BHTC & LL. & 5 & 1.8 & 4 Mammulia & & & & & & & \\
\hline $\mathrm{ST} \# 2$ & 5 & 1 & 0.28 & 8 Mammalia & & & & & & & Surface is nilled \\
\hline ST \#4 & 2 & 1 & 0.3 & 4 Mammalia & & & & Saw cul & & & \\
\hline ST \#9 & 1 & 1 & 0.86 & 6 Mammalia & & & & & & & \\
\hline ST $\# 9$ & 2 & 1 & 2.12 & 2 Mammalia & & & & & & & Surrace is pilled \\
\hline ST \#10 & 2 & 1 & 0.67 & 7. Mammalin & & & & 2 chons & & & \\
\hline ST \#18 & 4 & 25 & 15.26 & Mammalia & & & & & 2 Chaned & & \\
\hline ST $\$ 18$ & 6 & 3 & 1.1 & 5 Mammalia & & & & & 2 Chanred & & \\
\hline ST\#18 & 7 & 1 & 0.05 & Mammalia & & & & & & & Surface is pilled \\
\hline ST H23 & 6 & 2 & 0.15 & 9 Sylvilagus sp. & Maxilla & $\mathrm{L}$ & $\begin{array}{l}\text { Fragment of maxilla w/ check } \\
\text { loolh }\end{array}$ & & & & Identilicd by tooth \\
\hline ST $\# 23$ & 6 & 2 & 1.65 & 5 Sus scrofa & Pelvis & $\mathbf{R}$ & Chuck & Machinc sawed & & & \\
\hline ST \#24 & 4 & 3 & 0.88 & \begin{tabular}{l|l|} 
Mammalia \\
\end{tabular} & & & & & & & Surfice is pilted \\
\hline ST \#25 & 5 & 1 & 0.9. & Aves (Turkcy-sized) & & & & & & & \\
\hline ST $\# 25$ & 6 & 1 & 0.1 & & & & & & & & \\
\hline ST \#29 & 4 & 1 & 0.5 & & & & & & & & \\
\hline ST $\# 29$ & 5 & 4 & 2.1 & 4) Mammalia & & & & & & & Surface is nilled \\
\hline ST \#29 & 6 & 1 & 0.30 & Mammalin & & & & & Smoked & & \\
\hline $\mathrm{ST} \# 30$ & 1 & 1 & 0.35 & 9 Mammalia & & & & & Chanred & & \\
\hline ST $\# 30$ & 3 & 1 & 0.21 & aves & & & & & & & \\
\hline ST\#30 & 3 & 3 & 1.68 & 8 Mammalia & & & & & Smokcd & & \\
\hline ST \#30 & 4 & 1 & 0.05 & 9 Aves & & & & & Charted & & \\
\hline ST 130 & 4 & 1 & 0.1 & 7 Mammalia & & & & & Charrcd & & \\
\hline ST \#30 & 5 & 1 & 0.9 & 7 Mammalia & & & & & & & \\
\hline ST \#32 & 4 & 1 & 0.1 & \begin{tabular}{|l|l|}
5 & Tesludinac \\
\end{tabular} & & & & & Smaked & & \\
\hline ST \#32 & 4 & 1 & & 5 Mammalig & & & & & Charred & & \\
\hline ST 132 & 5 & 1 & 2.76 & 0. Manmalia & & & & & Charred & & \\
\hline ST 133 & 2 & 3 & 3.6 & i3 Manmalia & & & & & 2 Charred & & \\
\hline ST\#33 & 2 & 1 & 0.1 & 6. Mammalia & & & & & Chanred & & \\
\hline ST \#33 & 3 & 4 & 2.6 & 11 Mammalia & & & & & 1 Smoked & & 3 are henvily nitted \\
\hline ST $\# 33$ & 4 & 1 & 1.0 & Mammalia & & & & & ISmoked & & \\
\hline Totals & & 91 & $=131.9$ & & & & & & & & \\
\hline
\end{tabular}




\title{
Appendix C
}

\author{
Lithic Data
}

from 1996 Testing 
Appendix C. 1996 Lithic Data

\begin{tabular}{|c|c|c|c|c|c|c|c|c|}
\hline Shovel Test & Level & Ct. & Size Cat & Type & BTF? & Potlidded? & Material & Notes \\
\hline 1 & 2 & 1 & 3 & Tertiary & Yes & No & Chert & \\
\hline 2 & 1 & 1 & 2 & Tertiary & Yes & No & Chert & \\
\hline 3 & 2 & 2 & 2 & Secondary & No & No & Chert & \\
\hline 3 & 2 & 1 & 3 & Tertiary & No & No & quartzite & \\
\hline 3 & 3 & 2 & 3 & Tertiary & No & No & Chert & \\
\hline 3 & 3 & 1 & 5 & Secondary & No & No & Chert & \\
\hline 3 & 4 & 1 & 4 & Secondary & No & No & Chert & \\
\hline 4 & 1 & 1 & 2 & Tertiary & No & No & Chert & \\
\hline 4 & 2 & 1 & 2 & Secondary & No & No & Chert & \\
\hline 4 & 3 & 2 & 2 & Tertiary & No & No & Chert & \\
\hline 6 & 6 & 1 & 3 & Tertiary & No & No & Chert & \\
\hline 7 & 4 & 1 & 4 & Tertiary & Yes & No & Chert & Some patination \\
\hline 8 & 1 & 1 & 3 & Secondary & No & No & Chert & \\
\hline 8 & 5 & 2 & 2 & Tertiary & No & No & Chert & $\begin{array}{l}\text { Heavily patinated, mend to } 1 \text { other flake in this bag, } \\
\text { probably broken during excavation }\end{array}$ \\
\hline 8 & 5 & 1 & 3 & Tertiary & No & No & Chert & $\begin{array}{l}\text { Heavily patinated, mends to other } 2 \text { flakes in this bag, } \\
\text { probably broken during excavation }\end{array}$ \\
\hline 8 & 6 & 1 & 3 & Secondary & No & No & Chert & \\
\hline 9 & 1 & 1 & 2 & Secondary & No & No & Chert & \\
\hline 9 & 4 & 1 & 3 & Secondary & No & No & Chert & Heavily patinated \\
\hline 9 & 4 & 1 & 4 & Tertiary & No & No & Chert & Heavily patinated \\
\hline 10 & 3 & 1 & 3 & Secondary & No & No & Chert & \\
\hline 10 & 4 & 1 & 4 & Secondary & No & No & Chert & \\
\hline 10 & 5 & 1 & 2 & Tertiary & No & No & Chert & \\
\hline 11 & 5 & 1 & 3 & Secondary & No & No & Chert & \\
\hline 11 & 6 & 1 & 2 & Primary & No & No & Chert & \\
\hline 11 & 6 & 1 & 2 & Secondary & Yes & No & Chert & \\
\hline 11 & 7 & 1 & 2 & Tertiary & No & No & Chent & \\
\hline 12 & 1 & 1 & 3 & Tentiary & Yes & No & Chert & \\
\hline 12 & 5 & 1 & 2 & Secondary & No & No & Chert & \\
\hline 13 & 1 & 1 & 3 & Tertiary & No & No & Chert & \\
\hline 13 & 2 & 1 & 2 & Tertiary & No & No & Chert & \\
\hline 13 & 2 & 1 & 3 & Tertiary & No & No & Chert & \\
\hline 13 & 5 & 1 & 3 & Secondary & No & No & Chert & \\
\hline 14 & 3 & 1 & 3 & Secondary & No & No & Chert & \\
\hline 17 & 4 & 1 & 3 & Tertiary & No & No & Chert & \\
\hline 18 & 4 & 1 & 2 & Secondary & No & No & Chert. & \\
\hline 18 & 4 & 2 & 2 & Tertiary & No & No & Chert & \\
\hline 18 & 4 & 2 & 3 & Secondary & No & No & Chert & \\
\hline 18 & 6 & 1 & 2 & Tertiary & No & No & Chert & \\
\hline 18 & 6 & 1 & 3 & Tertiary & No & Yes & Chert & \\
\hline 18 & 7 & 1 & 5 & Secondary & No & No & Chert & \\
\hline 20 & 2 & 1 & 2 & Tertiary & No & No & Chert & Very heavily patinated \\
\hline 20 & 2 & 1 & 4 & Tertiary & No & No & Chert & \\
\hline 20 & 3 & 1 & 5 & Secondary & No & No & Chert & \\
\hline 20 & 4 & 2 & 2 & Tertiary & No & No & Chert & \\
\hline 20 & 4 & 1 & 2 & Tertiary & No & Yes & Chert & \\
\hline 20 & 4 & 2 & 3 & Tertiary & No & No & Chert & \\
\hline 20 & 4 & 1 & 5 & Tertiary & Yes & No & Chert & \\
\hline 20 & 7 & 1 & 3 & Tertiary & No & No & Chert & \\
\hline 20 & 7 & 1 & 4 & Tertiary & Yes & No & Chert & \\
\hline 23 & 1 & 1 & 4 & Secondary & No & No & Chert & \\
\hline 23 & 5 & 3 & 2 & Tertiary & No & $\mathrm{No}$ & Chert & \\
\hline 23 & 5 & 1 & 2 & Secondary & Yes & No & Chert & \\
\hline 23 & 5 & 1 & 3 & Tertiary & No & No & Chert & \\
\hline 23 & 5 & 1 & 4 & Tertiary & No & No & Chert & \\
\hline 23 & 6 & 1 & 2 & Secondary & No & No & Chent & \\
\hline 23 & 6 & 1 & 2 & Tertiary & No & Yes & Chert & \\
\hline 23 & 6 & 1 & 3 & Tertiary & No & No & Chert & \\
\hline 23 & 6 & 1 & 4 & Tertiary & $\mathrm{No}$ & No & Chert & \\
\hline 23 & 7 & 1 & 5 & Primary & No & No & Chert & Very burned \\
\hline
\end{tabular}


Appendix C. 1996 Lithic Data continued...

\begin{tabular}{|c|c|c|c|c|c|c|c|c|}
\hline Shovel Test & Level & Ct. & Size Cat & Type & BTF? & Potlidded? & Material & Notes \\
\hline 24 & 2 & 1 & 2 & Secondary & No & No & Cherl & \\
\hline 24 & 2 & 1 & 2 & Tertiary & No & No & Chert & \\
\hline 24 & 2 & 1 & 3 & Secondary & No & No & Chert & \\
\hline 24 & 2 & 1 & 3 & \begin{tabular}{|l|} 
Secondary \\
\end{tabular} & No & No & quartzite & \\
\hline 24 & 2 & 1 & 5 & Tertiary & Yes & No & Chert & \\
\hline 24 & 3 & 1 & 2 & Tertiary & No & No & Chert & \\
\hline 24 & 3 & 1 & 2 & Tertiary & No & Yes & Cherl & \\
\hline 24 & 3 & 1 & 3 & Tertiary & No & No & Chert & \\
\hline 24 & 3 & 1 & 5 & Tertiary & Yes & No & Chert & \\
\hline 24 & 4 & 3 & 2 & Tertiary & No & No & Chert & \\
\hline 24 & 4 & 1 & 3 & Secondary & No & No & Chert & \\
\hline 24 & 5 & 4 & 2 & Tertiary & No & No & Chert & \\
\hline 24 & 5 & 2 & 3 & Tertiary & No & No & Chert & \\
\hline 24 & 6 & 1 & 2 & \begin{tabular}{|l|} 
Primary \\
\end{tabular} & No & No & Chert & \\
\hline 24 & 6 & 2 & 2 & Secondary & No & No & Chert & \\
\hline 24 & 6 & 3 & 2 & Tertiary & No & No & Chert & \\
\hline 24 & 6 & 1 & 2 & Tertiary & Yes & No & Chert & \\
\hline 24 & 6 & 1 & 3 & Secondary & No & No & Chert & \\
\hline 24 & 6 & 4 & 3 & Tertiary & No & No & Chert & \\
\hline 24 & 6 & 1 & 3 & Tertiary & Yes & No & \begin{tabular}{|l|} 
Chert \\
\end{tabular} & \\
\hline 24 & 6 & 1 & 3 & \begin{tabular}{|l} 
Tertiary \\
\end{tabular} & No & Yes & Chert & Very potlidded \\
\hline 24 & 7 & 5 & 2 & Tertiary & No & No & Chert & \\
\hline 24 & 7 & 2 & 3 & Tertiary & No & No & Chert & \\
\hline 24 & 7 & 1 & 4 & Tertiary & No & No & Chert & \\
\hline 25 & 3 & 1 & 3 & Tertiary & No & No & Chert & \\
\hline 25 & 3 & 1 & 3 & Tertiary & Yes & No & Chert & \\
\hline 25 & 3 & 1 & 3 & Tertiary & No & Yes & Chert & \\
\hline 25 & 5 & 1 & 2 & Tertiary & No & No & Chert & \\
\hline 25 & 5 & $\mathbf{1}$ & 4 & Secondary & No & No & Chert & \\
\hline 25 & 6 & 1 & 2 & Tertiary & No & No & Chert & \\
\hline 25 & 7 & 1 & 2 & Tertiary & No & No & Chert & \\
\hline 25 & 7 & 2 & 3 & Tertiary & No & No & Chert & \\
\hline 25 & 7 & 1 & 4 & Tertiary & No & No & Chert & \\
\hline 25 & 7 & 1 & 4 & Tertiary & Yes & No & Chert & \\
\hline 25 & 7 & 1 & 6 & Secondary & No & No & Chert & \\
\hline 26 & 1 & 1 & 2 & Tertiary & No & No & Chert & \\
\hline 26 & 1 & 1 & 3 & \begin{tabular}{|l|} 
Tertiary \\
\end{tabular} & No & No & Chert & \\
\hline 26 & 2 & 1 & 2 & \begin{tabular}{|l|} 
Tertiary \\
\end{tabular} & No & No & Chert & \\
\hline 26 & 2 & 1 & 3 & Tertiary & No & No & Chert & \\
\hline 26 & 2 & 1 & 4 & Tertiary & Yes & No & Chert & \\
\hline 26 & 3 & 1 & 2 & Secondary & No & No & Chert & \\
\hline 26 & 3 & 1 & 4 & Tertiary & No & Yes & Chert & \\
\hline 26 & 3 & 1 & 5 & Secondary & Yes & No & Chert & Heavily patinated \\
\hline 26 & 4 & 1 & 3 & Tertiary & No & No & Chert & \\
\hline 26 & 5 & 1 & 5 & Primary & No & No & Chert & \\
\hline 26 & 6 & 1 & 3 & Secondary & No & No & Chert & \\
\hline 26 & 6 & 1 & 3 & Tertiary & Yes & No & Chert & \\
\hline 29 & 1 & 1 & 4 & \begin{tabular}{|l|} 
Primary \\
\end{tabular} & No & No & Chert & \\
\hline 29 & 1 & 1 & 4 & Secondary & No & No & Chert & \\
\hline 29 & 1 & 1 & 4 & Tertiary & No & No & Chert & \\
\hline 29 & 3 & 2 & 2 & Tertiary & No & No & Chert & \\
\hline 29 & 3 & 1 & 3 & Tertiary & Yes & No & Chert & \\
\hline 29 & 3 & 1 & 4 & Tertiary & No & No & Chert & \\
\hline 29 & 4 & 4 & 2 & Secondary & No & No & Chert & \\
\hline 29 & 4 & $\overline{15}$ & 2 & Tertiary & No & No & Chert & \\
\hline 29 & 4 & 1 & 2 & \begin{tabular}{|l|} 
Tertiary \\
\end{tabular} & Yes & No & Chert & \\
\hline 29 & 4 & 1 & 2 & Tertiary & No & Yes & Chert & \\
\hline 29 & 4 & 11 & 3 & Tertiary & No & No & Chert & \\
\hline 29 & 4 & 1 & 3 & \begin{tabular}{|l|} 
Tertiary \\
\end{tabular} & Yes & No & Chert & \\
\hline 29 & 4 & 1 & 3 & Tertiary & No & Yes & Chert & \\
\hline 29 & 4 & 1 & 5 & Tertiary & Yes & No & Chert & \\
\hline 29 & 5 & 3 & 2 & Tertiary & No & No & Chert & \\
\hline
\end{tabular}


Appendix C. 1996 Lithic Data continued...

\begin{tabular}{|c|c|c|c|c|c|c|c|c|}
\hline Shovel Test & Level & Ct. & Size Cat & Type & BTF? & Potlidded? & Material & Notes \\
\hline 29 & 5 & 2 & 2 & Secondary & Yes & No & Chert & \\
\hline 29 & 5 & 3 & 2 & Tertiary & Yes & No & Chert & \\
\hline 29 & 5 & 1 & 2 & Tertiary & No & Yes & Chert & \\
\hline 29 & 5 & 1 & 3 & Secondary & No & No & Chert & \\
\hline 29 & 5 & 1 & 3 & Tertiary & No & No & Chert & \\
\hline 29 & 5 & 1 & 3 & Tertiary & No & No & Chert & Heavily patinated \\
\hline 29 & 5 & 1 & 4 & Secondary & No & No & Chert & \\
\hline 29 & 5 & 3 & 4 & Tertiary & No & No & Chert & \\
\hline 29 & 5 & 2 & 4 & Tertiary & Yes & No & Chert & \\
\hline 29 & 5 & 1 & 5 & Secondary & Yes & No & Chert & \\
\hline 29 & 6 & 1 & 2 & Tertiary & No & No & \begin{tabular}{|l|} 
Chert \\
\end{tabular} & \\
\hline 29 & 6 & 1 & 3 & Tertiary & No & No & Chert & \\
\hline 29 & 6 & 1 & 3 & Tertiary & Yes & No & Chert & \\
\hline 29 & 6 & 1 & 3 & Tertiary & No & Yes & Chert & \\
\hline 29 & 6 & 1 & 4 & Secondary & No & No & Chert & \\
\hline 29 & 7 & 1 & 2 & Tertiary & No & No & Chert & \\
\hline 29 & 7 & 1 & 2 & Tertiary & Yes & No & Chert & \\
\hline 29 & 7 & 1 & 3 & Primary & No & No & Chert & \\
\hline 29 & 7 & 2 & 3 & Tertiary & No & No & Chert & \\
\hline 29 & 7 & 1 & 5 & Tertiary & No & No & Chert & \\
\hline 30 & 2 & 1 & 2 & Primary & No & No & Chert & \\
\hline 30 & 2 & 4 & 2 & Secondary & No & No & Chert & \\
\hline 30 & 2 & 4 & 2 & Tertiary & No & No & Chert & \\
\hline 30 & 2 & 1 & 2 & Tertiary & Yes & No & \begin{tabular}{|l|} 
Chert \\
\end{tabular} & \\
\hline 30 & 2 & 1 & 3 & Primary & No & No & Chert & \\
\hline 30 & 2 & 1 & 4 & Tertiary & Yes & No & Chert & \\
\hline 30 & 2 & 1 & 5 & \begin{tabular}{|l|} 
Primary \\
\end{tabular} & No & No & Chert & \\
\hline 30 & 2 & 1 & 5 & Secondary & Yes & No & Chert & \\
\hline 30 & 3 & 1 & 2 & Primary & No & No & Chert & \\
\hline 30 & 3 & 1 & 2 & Secondary & No & No & Chert & \\
\hline 30 & 3 & 36 & 2 & Tertiary & No & No & Chert & \\
\hline 30 & 3 & 1 & 2 & Secondary & Yes & No & Chert & \\
\hline 30 & 3 & 11 & 2 & Tertiary & Yes & No & Chert & \\
\hline 30 & 3 & 9 & 2 & Tertiary & No & Yes & Chert & \\
\hline 30 & 3 & 1 & 3 & Primary & No & No & Chert & \\
\hline 30 & 3 & 6 & 3 & Secondary & No & No & Chert & \\
\hline 30 & 3 & 1 & 3 & Secondary & No & No & Quartzite & \\
\hline 30 & 3 & 14 & 3 & Tertiary & No & No & \begin{tabular}{|l|} 
Chert \\
\end{tabular} & \\
\hline 30 & 3 & 7 & 3 & Tertiary & Yes & No & Chert & \\
\hline 30 & 3 & 5 & 3 & Tertiary & No & Yes & Chert & \\
\hline 30 & 3 & 1 & 3 & Tertiary & Yes & Yes & \begin{tabular}{|l|} 
Chert \\
\end{tabular} & \\
\hline 30 & 3 & 1 & 4 & Primary & No & No & \begin{tabular}{|l|} 
Chert \\
\end{tabular} & \\
\hline 30 & 3 & 2 & 4 & Tertiary & No & No & Chert & \\
\hline 30 & 3 & 1 & 4 & Tertiary & No & Yes & Chert & \\
\hline 30 & 3 & 1 & 4 & Tertiary & Yes & Yes & Chert & \\
\hline 30 & 3 & 1 & 5 & Tertiary & No & Yes & Chert & Very potlidded \\
\hline 30 & 3 & 1 & 6 & Secondary & No & No & Chert & \\
\hline 30 & 3 & 1 & 7 & Secondary & No & No & Chert & \\
\hline 30 & 4 & 1 & 2 & Primary & No & No & Chert & \\
\hline 30 & 4 & 3 & 2 & Secondary & No & No & Chert & \\
\hline 30 & 4 & 51 & 2 & Tertiary & No & No & \begin{tabular}{|l|} 
Chert \\
\end{tabular} & \\
\hline 30 & 4 & 8 & 2 & Tertiary & Yes & No & Chert & \\
\hline 30 & 4 & 1 & 2 & \begin{tabular}{|l|} 
Secondary \\
\end{tabular} & No & Yes & Chert & \\
\hline 30 & 4 & 2 & 2 & Tertiary & No & Yes & Chert & \\
\hline 30 & 4 & 1 & 2 & Secondary & Yes & Yes & Chert & \\
\hline 30 & 4 & 3 & 3 & \begin{tabular}{|l|} 
Primary \\
\end{tabular} & No & No & \begin{tabular}{|l|} 
Chert \\
\end{tabular} & \\
\hline 30 & 4 & 2 & 3 & Secondary & No & No & Chert & \\
\hline 30 & 4 & 22 & 3 & Tertiary & No & No & Chert & \\
\hline 30 & 4 & 1 & 3 & Secondary & Yes & No & Chert & \\
\hline 30 & 4 & 7 & 3 & Tertiary & Yes & No & Chert & \\
\hline 30 & 4 & 1 & 3 & Secondary & No & Yes & Chert & \\
\hline
\end{tabular}


Appendix C. 1996 Lithic Data continued...

\begin{tabular}{|c|c|c|c|c|c|c|c|c|}
\hline Shovel Test & Level & $\mathrm{Ct}$. & Size Cat & Type & BTF? & Potlidded? & Material & Notes \\
\hline 30 & 4 & 1 & 3 & Tertiary & No & Yes & Chert & \\
\hline 30 & 4 & 2 & 3 & Tertiary & Yes & Yes & Chert & \\
\hline 30 & 4 & 1 & 4 & Secondary & No & No & Chent & \\
\hline 30 & 4 & 4 & 4 & Tertiary & No & No & Chert & \\
\hline 30 & 4 & 1 & 4 & Secondary & Yes & $\mathrm{No}$ & Chert & \\
\hline 30 & 4 & 1 & 4 & Tertiary & Yes & $\mathrm{No}$ & Chert & \\
\hline 30 & 4 & 1 & 4 & Tertiary & No & Yes & Chert & \\
\hline 30 & 4 & 1 & 4 & Secondary & Yes & Yes & Chert & \\
\hline 30 & 4 & 1 & 5 & Tertiary & Yes & No & Chert & \\
\hline 30 & 5 & 5 & 2 & Tertiary & No & No & Chert & \\
\hline 30 & 5 & 1 & 2 & Tertiary & No & Yes & Chert & \\
\hline 30 & 5 & 2 & 3 & Tertiary & No & No & Chert & \\
\hline 32 & 2 & 2 & 3 & Secondary & $\mathrm{No}$ & No & Chert & \\
\hline 32 & 2 & 1 & 6 & Secondary & No & No & Chert & \\
\hline 32 & 3 & 1 & 2 & Tertiary & No & No & Chert & \\
\hline 32 & 3 & 1 & 3 & Primary & No & No & Chert & \\
\hline 32 & 3 & 1 & 3 & Secondary & No & No & Chert & \\
\hline 32 & 3 & 2 & 3 & Tertiary & $\mathrm{No}$ & No & Chert & \\
\hline 32 & 3 & 1 & 3 & Tertiary & Yes & No & Chert & \\
\hline 32 & 3 & 3 & 4 & Secondary & No & No & Chert & \\
\hline 32 & 3 & 1 & 4 & Tertiary & No & No & Chert & \\
\hline 32 & 3 & 1 & 5 & Secondary & No & $\mathrm{No}$ & Chert & \\
\hline 32 & 3 & 1 & 6 & Secondary & No & No & Chert & \\
\hline 32 & 4 & 1 & 2 & Secondary & No & No & Chert & \\
\hline 32 & 4 & 3 & 2 & Tertiary & No & No & Chert & \\
\hline 32 & 4 & 1 & 3 & Secondary & No & No & Chert & \\
\hline 32 & 4 & 7 & 3 & Tertiary & No & No & Chert & \\
\hline 32 & 4 & 1 & 3 & Secondary & Yes & No & Chert & \\
\hline 32 & 4 & 1 & 3 & Tertiary & Yes & No & Chert & \\
\hline 32 & 4 & 1 & 4 & Secondary & No & No & Chert & \\
\hline 32 & 4 & 1 & 4 & Tertiary & No & No & Chert & \\
\hline 32 & 4 & 2 & 4 & Tertiary & Yes & No & Chert & \\
\hline 32 & 4 & 1 & 5 & Secondary & No & No & Chert & \\
\hline 32 & 5 & 4 & 3 & Tertiary & No & No & Chert & \\
\hline 32 & 5 & 1 & 4 & Tertiary & No & No & Chert & \\
\hline 32 & 5 & 1 & 5 & Tertiary & Yes & No & Chert & \\
\hline 32 & 6 & 1 & 2 & Tertiary & No & No & Chert & \\
\hline 32 & 6 & 5 & 3 & Tertiary & No & No & Chert & \\
\hline 32 & 6 & 1 & 3 & Tertiary & No & Yes & Chert & Heavily patinated \\
\hline 32 & 6 & 1 & 4 & Tertiary & No & No & Chert & \\
\hline 33 & 1 & 2 & 2 & Tertiary & No & No & Chert & \\
\hline 33 & 1 & 1 & 3 & Primary & No & No & Chent & \\
\hline 33 & 1 & 1 & 3 & Secondary & No & $\mathrm{No}$ & Chert & \\
\hline 33 & 1 & 2 & 3 & Tertiary & No & No & Chert & \\
\hline 33 & 1 & 1 & 6 & Secondary & No & Yes & Chert & \\
\hline 33 & 2 & 1 & 2 & Primary & No & No & Chert & \\
\hline 33 & 2 & 4 & 2 & Secondary & No & No & Chert & \\
\hline 33 & 2 & 15 & 2 & Tertiary & No & No & Chert & \\
\hline 33 & 2 & 1 & 2 & Tentiary & Yes & No & Chert & \\
\hline 33 & 2 & 1 & 2 & Secondary & No & Yes & Chert & \\
\hline 33 & 2 & 3 & 2 & Tertiary & No & Yes & Chert & \\
\hline 33 & 2 & 2 & 3 & Primary & No & No & Chert & \\
\hline 33 & 2 & 4 & 3 & Secondary & No & No & Chent & \\
\hline 33 & 2 & 9 & 3 & Tertiary & No & No & Chert & \\
\hline 33 & 2 & 4 & 3 & Tertiary & Yes & No & Chert & \\
\hline 33 & 2 & 2 & 3 & Tertiary & No & Yes & Chert & \\
\hline 33 & 2 & 1 & 4 & Primary & No & No & Chert & \\
\hline 33 & 2 & 4 & 4 & Secondary & No & No & Chert & \\
\hline 33 & 2 & 1 & 4 & Tertiary & $\mathrm{No}$ & No & Chert & \\
\hline 33 & 2 & 1 & 4 & Tertiary & No & No & Quartzite & \\
\hline 33 & 2 & 1 & 4 & Tertiary & No & Yes & Chert & \\
\hline
\end{tabular}


Appendix C. 1996 Lithic Data continued...

\begin{tabular}{|c|c|c|c|c|c|c|c|c|}
\hline Shovel Test & Level & Ct. & Size Cat & Type & BTF? & Potlidded? & Material & Notes \\
\hline 33 & 2 & 1 & 5 & Tertiary & No & No & Chert & \\
\hline 33 & 2 & 1 & 5 & Tertiary & Yes & No & Chert & \\
\hline 33 & 3 & 3 & 2 & Secondary & No & No & Chert & \\
\hline 33 & 3 & 11 & 2 & \begin{tabular}{|l|} 
Tertiary \\
\end{tabular} & No & No & Chert & \\
\hline 33 & 3 & 1 & 2 & Tertiary & Yes & No & Chert & \\
\hline 33 & 3 & 7 & 3 & Secondary & No & No & Chert & \\
\hline 33 & 3 & 6 & 3 & Tertiary & No & No & Chert & \\
\hline 33 & 3 & 1 & 3 & Tertiary & Yes & No & Chert & \\
\hline 33 & 3 & 1 & 3 & Tertiary & Yes & No & Chert & \\
\hline 33 & 3 & 1 & 3 & Secondary & No & Yes & Chert & \\
\hline 33 & 3 & 1 & 3 & Tertiary & No & Yes & Chert & \\
\hline 33 & 3 & 2 & 4 & Secondary & No & No & Chert & \\
\hline 33 & 3 & 1 & 4 & Tertiary & No & No & Quartzite & \\
\hline 33 & 3 & 1 & 4 & Secondary & No & Yes & Chert & \\
\hline 33 & 3 & 1 & 6 & Secondary & No & No & Chert & \\
\hline 33 & 4 & 3 & 2 & Secondary & No & No & Chert & \\
\hline 33 & 4 & 9 & 2 & Tertiary & No & No & Chert & \\
\hline 33 & 4 & 1 & 2 & Tertiary & Yes & $\mathrm{No}$ & Chert & \\
\hline 33 & 4 & 4 & 3 & Primary & No & No & Chert & \\
\hline 33 & 4 & 3 & 3 & \begin{tabular}{|l|} 
Secondary \\
\end{tabular} & No & No & Chert & \\
\hline 33 & 4 & 8 & 3 & Tertiary & No & No & Chert & \\
\hline 33 & 4 & 2 & 4 & Secondary & No & No & Chert & \\
\hline 33 & 4 & 2 & 4 & Tertiary & No & No & Chert & \\
\hline 33 & 4 & 1 & 4 & Tertiary & Yes & No & Chert & \\
\hline 33 & 5 & 1 & 2 & Tertiary & No & No & Chert: & \\
\hline 33 & 5 & 2 & 3 & Tertiary & No & No & Chert: & \\
\hline 33 & 5 & 1 & 4 & Primary & No & No & Chert & \\
\hline 33 & 6 & 1 & 3 & Tertiary & No & No & Chert & \\
\hline 33 & 7 & 1 & 2 & Tertiary & No & No & Chert & \\
\hline 33 & 7 & 1 & 3 & Secondary & No & Yes & Chert & \\
\hline 34 & 1 & 1 & 4 & \begin{tabular}{|l|} 
Secondary \\
\end{tabular} & No & No & Chert & \\
\hline 34 & 5 & 1 & 3 & Tertiary & No & No & Chert & \\
\hline 34 & 6 & 3 & 4 & Secondary & No & No & Chert & \\
\hline 37 & 3 & 4 & 2 & Tertiary & No & No & Chert & \\
\hline 37 & 3 & 1 & 2 & Tertiary & Yes & No & Chert & \\
\hline 37 & 3 & 1 & 3 & Primary & No & No & Chert & \\
\hline 37 & 3 & 1 & 3 & Secondary & No & No & Chert & \\
\hline 37 & 3 & 7 & 3 & Tertiary & No & No & Chert & \\
\hline 37 & 3 & 1 & 3 & Tertiary & No & No & Chert & \\
\hline 37 & 3 & 1 & 3 & Tertiary & No & No & Quartzite & Very fine-grained quartzite \\
\hline 37 & 3 & 4 & 3 & Tertiary & No & No & Chert & \\
\hline 37 & 3 & 1 & 4 & Tertiary & No & No & Chert & \\
\hline 37 & 3 & 2 & 4 & Tertiary & Yes & No & Chert & \\
\hline 38 & 1 & 1 & 4 & Tertiary & No & No & Chert & \\
\hline \multicolumn{9}{|l|}{ Backhoe Trenches } \\
\hline BHT B $15-35$ & & 1 & 3 & Tertiary & Yes & No & Chert & \\
\hline BHT B $15-35$ & & 1 & 5 & Secondary & No & Yes & Chert & \\
\hline BHT B $15-35$ & & 1 & 4 & Primary & No & No & Chert & May be machine-made \\
\hline BHT B $15-35$ & & 1 & 7 & Primary & No & No & Chert & May be machine-made \\
\hline BHT B 30-50 & & 1 & 5 & Primary & No & No & Chert & May be machine-made \\
\hline BHT B 30-50 & & 1 & 5 & Tertiary & No & No & Chert & \\
\hline BHT B 30-50 & & 1 & 6 & Secondary & No & No & Chert & \\
\hline BHT в $30-50$ & & 1 & 11 & Secondary & No & No & Chert & May be machine-made \\
\hline BHT C Lt. soil & & 1 & 2 & Secondary & No & No & Chert & \\
\hline BHT C Dk Soil & & 1 & $\underline{2}$ & Tertiary & No & No & Chert & \\
\hline BHT C Dk Soil & & 1 & 6 & Secondary & No & No & Chert & \\
\hline
\end{tabular}


Appendix D

Artifact Data

from 1998 Testing 


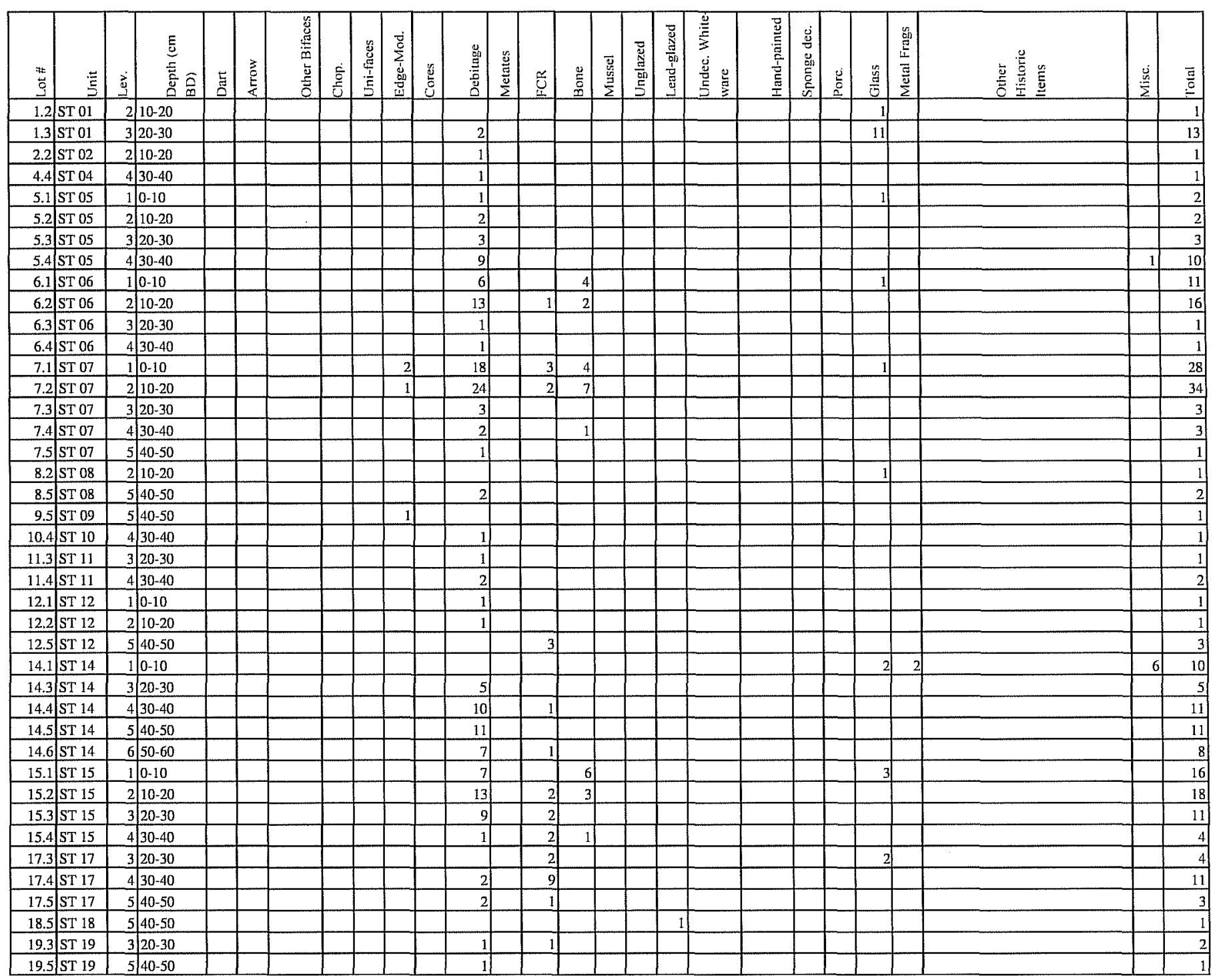




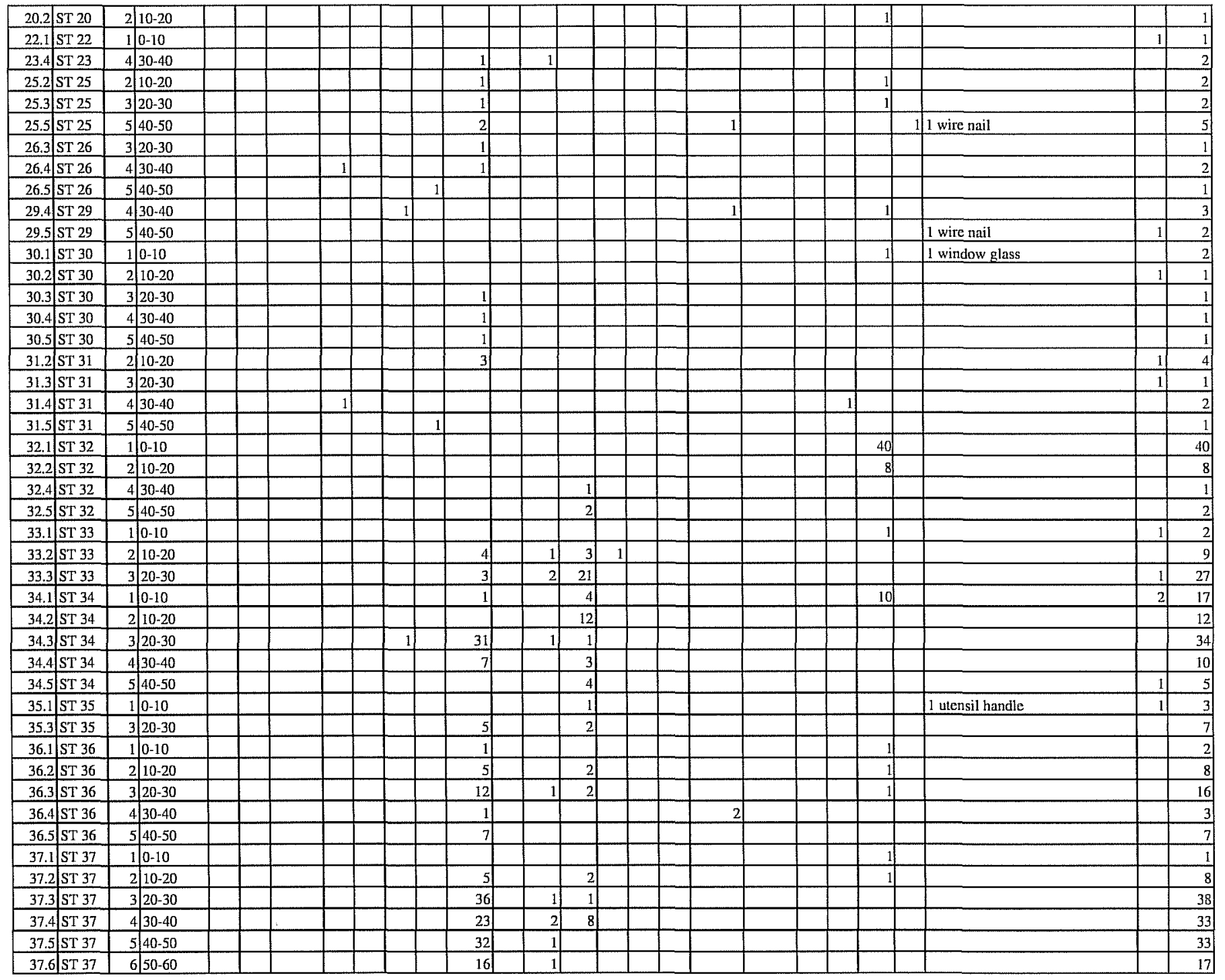




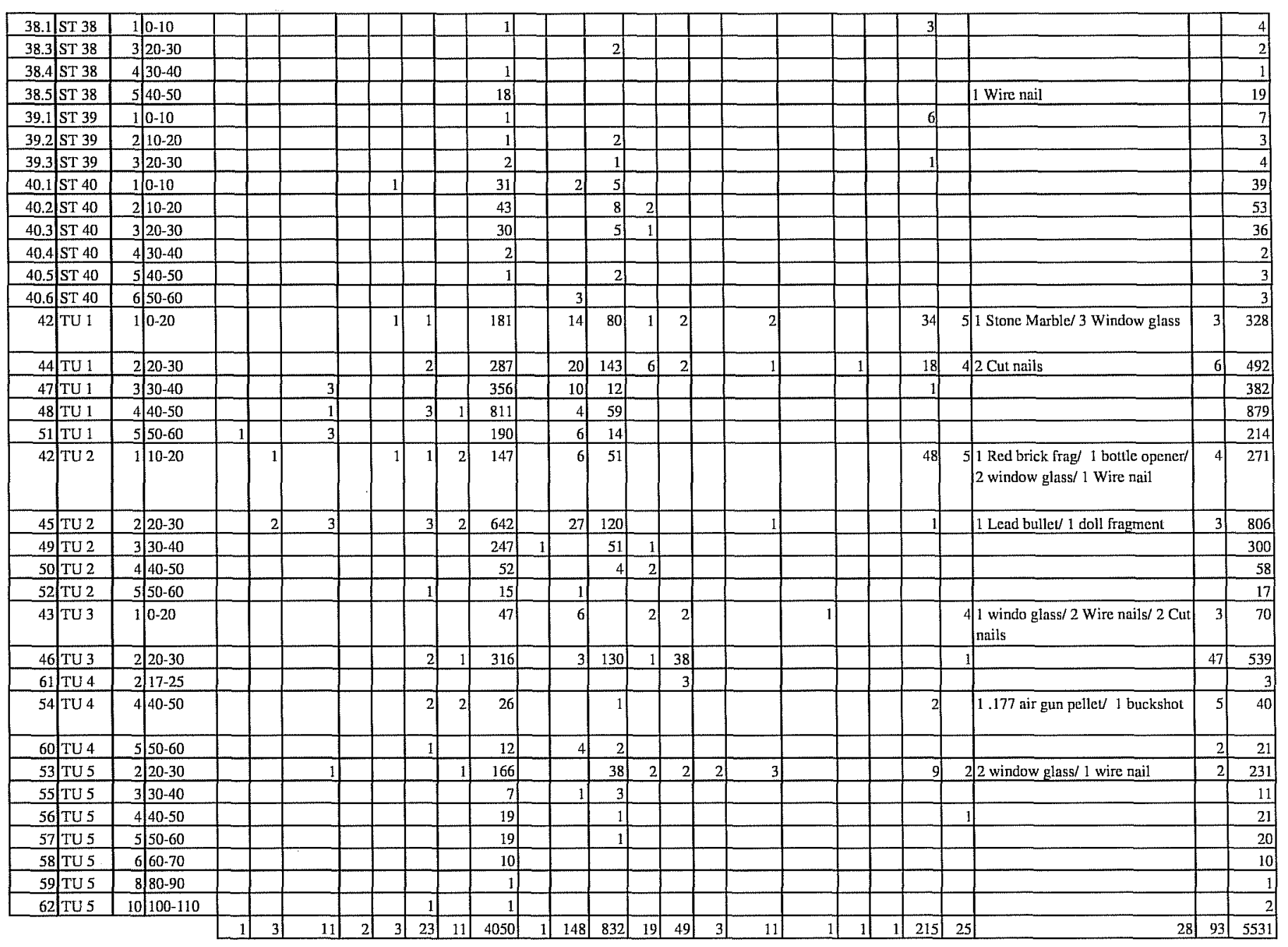


Appendix E

Faunal Data

from 1998 Testing 


\begin{tabular}{|c|c|c|c|c|c|c|c|c|c|c|c|c|c|c|c|}
\hline & & & & & & & & & Butcher & arks & & & & & \\
\hline Bag\# & Unit \# & Lv. & Taxon & Count & $\mathrm{Wgt}(\mathrm{g})$ & Element & Portion & Juv? & Type & Count & Brks & Burn & Weath & Pit & Gnaw \\
\hline 6.1 & ST 06 & 1 & Mammal & 2 & 2.27 & & & & & & 3 & 0 & 0 & 0 & \\
\hline 6.1 & ST 06 & 1 & Mammal & 2 & 0.11 & & & & & & & 0 & $\mathrm{~N}$ & $\mathrm{~N}$ & \\
\hline 6.2 & ST 06 & 2 & Mammal & 2 & 2.10 & & & & & & & 0 & $\mathrm{~N}$ & $\mathrm{~N}$ & \\
\hline 7.1 & ST 07 & 1 & Mammal & 4 & 0.41 & & & & & & & 0 & $\mathrm{~N}$ & $\mathrm{~N}$ & \\
\hline 7.2 & ST 07 & 2 & Mammal & 6 & 0.39 & & & & & & & 0 & $\mathrm{~N}$ & $\mathrm{~N}$ & \\
\hline 7.2 & ST 07 & 2 & Mammal & 1 & 0.04 & & & & & & & 0 & $\mathrm{~N}$ & $\mathrm{~N}$ & \\
\hline 7.4 & ST 07 & 4 & Mammal & 1 & 0.08 & & & & & & & 0 & $\mathrm{~N}$ & $\mathrm{~N}$ & \\
\hline 15.1 & ST 15 & 1 & Aves--large & 1 & 0.34 & Long bone & Fragment & & & & 1 & 0 & 0 & 0 & \\
\hline 15.1 & ST 15 & 1 & Mammal & 3 & 1.14 & & & & & & & 1 & $\mathrm{~N}$ & $\mathrm{~N}$ & \\
\hline 15.1 & ST 15 & 1 & Mammal & 2 & 2.81 & & & & & & & 0 & $\mathrm{~N}$ & $\mathrm{~N}$ & \\
\hline 15.2 & ST 15 & 2 & Bovinae & 2 & 10.05 & Molar & Fragment & & & & & 0 & $\mathrm{~N}$ & $\mathrm{~N}$ & \\
\hline 15.2 & ST 15 & 2 & Mammal & 1 & 0.32 & & & & & & & 0 & $\mathrm{~N}$ & $\mathrm{~N}$ & \\
\hline 15.4 & ST 15 & 4 & Marnmal & 1 & 1.17 & & & & & & & 3. & $\mathrm{~N}$ & $\mathrm{~N}$ & \\
\hline 32.4 & ST 32 & 4 & Artiodactyl & 1 & 0.87 & 3rd phalange & Plantar surface & & & & & 0 & 0 & 0 & 1 \\
\hline 32.5 & ST 32 & 5 & Odocoileus vriginianus & 1 & 6.07 & 1st phalange & Complete & & & & 0 & 1 & 0 & 0 & 3 \\
\hline 32.5 & ST 32 & 5 & Mammal & 1 & 1.03 & & & & & & & 0 & $\mathrm{~N}$ & $\mathrm{~N}$ & \\
\hline 33.2 & ST 33 & 2 & Odocoileus vriginianus & 2 & 6.77 & Metatarsal & $\begin{array}{l}\text { Fragment of } \\
\text { diaphysis }\end{array}$ & & & & 3 & 0 & 1 & 1 & \\
\hline 33.2 & ST 33 & 2 & Colubridae & 1 & 0.17 & Vertebra & Fragment & & & & & 0 & $\mathrm{~N}$ & $\mathrm{~N}$ & \\
\hline 33.3 & ST 33 & 3 & Didelphis virginiana & 1 & 0.71 & Cervical vertebra & $\begin{array}{l}\text { No spinous } \\
\text { process }\end{array}$ & & & & 2 & 0 & 0 & 0 & \\
\hline 33.3 & ST 33 & 3 & Mammal--very small & 1 & 0.30 & Long bone & Fragment & & & & & 0 & $\mathrm{~N}$ & $\mathrm{~N}$ & \\
\hline 33.3 & ST 33 & 3 & Mammal--very large & 1 & 4.33 & Long bone & Fragment & & & & 3 & 0 & 1 & 0 & \\
\hline 33.3 & ST 33 & 3 & Mammal & 2 & 0.47 & & & & & & & 2 & $\mathrm{~N}$ & $\mathrm{~N}$ & \\
\hline 33.3 & ST 33 & 3 & Mammal & 16 & 6.30 & & & & & & & 0 & $\mathrm{~N}$ & $\mathrm{~N}$ & \\
\hline 34.1 & ST 34 & 1 & Mammal & 4 & 2.00 & & & & & & & 0 & $\mathrm{~N}$ & $\mathrm{~N}$ & \\
\hline 34.2 & ST 34 & 2 & Mammal--small & 1 & 0.13 & & & & & & & 0 & 0 & 0 & \\
\hline 34.2 & ST 34 & 2 & Mammal & 10 & 2.07 & & & & & & & 0 & $\mathrm{~N}$ & $\mathrm{~N}$ & \\
\hline 34.2 & ST 34 & 2 & Mammal & 1. & 0.43 & & & & & & & 2 & $\mathrm{~N}$ & $\mathrm{~N}$ & \\
\hline 34.3 & ST 34 & 3 & Mammal & 1 & 0.13 & & & & & & & 0 & $\mathrm{~N}$ & $N$ & \\
\hline 34.4 & ST 34 & 4 & Mammal & 1 & 0.14 & & & & & & & 0 & $\mathrm{~N}$ & $\mathrm{~N}$ & \\
\hline 34.4 & ST 34 & 4 & Mammal & 2 & 0.25 & & & & & & & 1 & $\mathrm{~N}$ & $\mathrm{~N}$ & \\
\hline 34.5 & ST 34 & 5 & Mammal & 4 & 0.80 & & & & & & & 0 & $\mathrm{~N}$ & $\mathrm{~N}$ & \\
\hline 35.1 & ST 35 & 1 & Mammal & 1 & 2.77 & & & & Hand saw & 1 & 3 & 0 & 0 & 0 & \\
\hline 35.3 & ST 35 & 3 & Mammal--large & 2 & 3.70 & Illium & Sirloin cut & & Hand saw & 2 & 3 & 0 & 0 & 0 & \\
\hline 36.2 & ST 36 & 2 & Mammal & 2 & 0.61 & & & & & & & 0 & $\mathrm{~N}$ & $\mathrm{~N}$ & \\
\hline 36.3 & ST 36 & 3 & Mammal & 2 & 0.83 & & & & & & & 0 & $\mathrm{~N}$ & $\mathrm{~N}$ & \\
\hline 37.2 & ST 37 & 2 & Mammal & 1 & 0.11 & & & & & & & 0 & $\mathrm{~N}$ & $\mathrm{~N}$ & \\
\hline 37.2 & ST 37 & 2 & Mammal--very large & 1) & 0.50 & & & & & & & 0 & $N$ & $\mathrm{~N}$ & \\
\hline
\end{tabular}




\begin{tabular}{|c|c|c|c|c|c|c|c|c|c|c|c|c|c|c|c|}
\hline & & & & & & & & & Butcher II & arks & & & & & \\
\hline Bag\# & Unit \# & Lv. & Taxon & Count & $\mathrm{Wgt}(\mathrm{g})$ & Element & Portion & Juv? & Type & Count & Brks & Burn & Weath & Pit & Gnaw \\
\hline 37.3 & ST 37 & 3 & Mammal & 1 & 0.20 & & & & & & & 2 & $\mathrm{~N}$ & $\mathrm{~N}$ & \\
\hline 37.4 & ST 37 & 4 & Artiodactyl & 2 & 3.04 & Metatarsal & $\begin{array}{l}\text { Fragment of } \\
\text { proximal end }\end{array}$ & & & & 3 & 1 & 1 & 1 & \\
\hline 37.4 & ST 37 & 4 & Mammal & 4 & 2.09 & & & & & & & 1 & $\mathrm{~N}$ & $\mathrm{~N}$ & \\
\hline 37.4 & ST 37 & 4 & Mammal & 2 & 0.65 & & & & & & & 0 & $N$ & $\mathrm{~N}$ & \\
\hline 38.3 & ST 38 & 3 & Odocoileus vriginianus & 1 & 1.77 & 3rd phalange & $\begin{array}{l}\text { All but distal } \\
\text { tip }\end{array}$ & & & & & 2 & 0 & 0 & \\
\hline 38.3 & ST 38 & 3. & Mammal & 1 & 0.13 & & & & & & & 1 & 0 & 0 & \\
\hline 39.3 & ST 39 & 2. & Mammal & 2 & 0.21 & & & & & & & 0 & $\mathrm{~N}$ & $\mathrm{~N}$ & \\
\hline 39.3 & ST 39 & 3. & Mammal & 1 & 0.81 & & & & & & & 3 & $\mathrm{~N}$ & $\mathrm{~N}$ & \\
\hline 40.1 & ST 40 & 1 & Mammal & 5 & 2.08 & & & & & & & 1 & $\mathrm{~N}$ & $\mathrm{~N}$ & \\
\hline 40.2 & ST 40 & 2. & Mammal & 5 & 0.84 & & & & & & & 0 & $\mathrm{~N}$ & $\mathrm{~N}$ & \\
\hline 40.2 & ST 40 & 2 & Mammal & 2 & 0.25 & & & & & & & 1 & $\mathrm{~N}$ & $\mathrm{~N}$ & \\
\hline 40.2 & ST 40 & 2 & Aves--large & 1 & 0.11 & Long bone & Fragment & & & & & 2 & $\mathrm{~N}$ & $\mathrm{~N}$ & \\
\hline 40.3 & ST 40 & 3 & Mammal & 3. & 0.48 & & & & & & & 요 & $\mathrm{N}$ & $\mathrm{N}$ & \\
\hline 40.3 & ST 40 & 3 & Mammal & 1 & 0.05 & & & & & & & 3 & $\mathrm{~N}$ & $\mathrm{~N}$ & \\
\hline 40.3 & ST 40 & 3 & Mammal & 1 & 0.53 & & & & & & & 1 & $\mathrm{~N}$ & $\mathrm{~N}$ & \\
\hline 40.5 & ST 40 & 5 & Mammal & 2 & 0.18 & & & & & & & 1 & $\mathrm{~N}$ & $\mathrm{~N}$ & \\
\hline 43 & TU 01 & 1 & Bos taurus & 1 & 10.76 & Rib & Fragment & & Mach. Saw & 2 & 1. & 아 & 0 & 요 & \\
\hline 43 & TU 01 & 1 & Aves--large & 1 & 0.71 & Long bone & Fragment & & & & 1 & 0 & 0 & 0 & \\
\hline 43 & TU 01 & 1 & Mammal--large & 1 & 3.31 & Long bone & Fragment & & Thick cut & 1 & & 0 & 2 & 1 & \\
\hline 43 & TU 01 & 1 & Mammal--large & 1 & 2.51 & Long bone & Fragment & & & & 3 & 0 & 2 & 1 & \\
\hline 43 & TU 01 & 1 & Mammal & 2 & 1.14 & & & & & & & 4 & $\mathrm{~N}$ & $\mathrm{~N}$ & \\
\hline 43 & TU 01 & 1 & Mammal & 5 & 2.89 & & & & & & & 0 & $\mathrm{~N}$ & $\mathrm{~N}$ & \\
\hline 41 & TU 01 & 1 & Equus cf. caballos & 1 & 10.43 & Incisor & \begin{tabular}{|l} 
Almost \\
complete
\end{tabular} & & & & 2 & 0 & 0 & 0 & \\
\hline 41 & TU 01 & 1 & Canis sp. & 1 & 0.71 & Premolar & \begin{tabular}{|l} 
Almost \\
complete
\end{tabular} & & & & 2 & 0 & 이 & 0 & \\
\hline 41 & TU 01 & 1 & Odocoileus vriginianus & 1 & 3.21 & Metatarsal & $\begin{array}{l}\text { Fragment of } \\
\text { diaphysis }\end{array}$ & & & & 2 & 0 & 1 & 1 & \\
\hline 41 & TU 01 & 1. & Mammal & 1 & 1,30 & Long bone & Fragment & & Hand saw & 1 & 3 & 0 & 1 & 1 & \\
\hline 41 & TU 01 & 1 & Bovinae & 1 & 3.19 & Proximal sesmoid & Complete & & & & 0 & 0 & of & 0 & \\
\hline 41 & TU 01 & 1 & Mammal--very large & 1 & 5.33 & Long bone & Fragment & & & & 1 & 0 & 0 & 1 & \\
\hline 41 & TU 01 & 1 & Mammal--very large & 2 & 5.71 & Long bone & Fragment & & & & & 0 & $\mathrm{~N}$ & $\mathrm{~N}$ & \\
\hline 41 & TU 01 & 1 & Mammal & 1 & 0.64 & & & & & & & 3 & $\mathrm{~N}$ & $\mathrm{~N}$ & \\
\hline 41 & TU 01 & 1 & Mammal & 3 & 0.58 & & & & & & & 2 & $\mathrm{~N}$ & $\mathrm{~N}$ & \\
\hline 41 & TU 01 & 1 & Mammal & 11 & 3.29 & & & & & & & 1 & $N$ & $\mathrm{~N}$ & \\
\hline 41 & TU 01 & 1 & Mammal & 2 & 1.72 & & & & & & & 요 & 1 & 0 & \\
\hline 41 & TU 01 & $1)$ & Mammal & 7 & 6.55 & & & & & & & 0 & 0 & 0 & \\
\hline
\end{tabular}




\begin{tabular}{|c|c|c|c|c|c|c|c|c|c|c|c|c|c|c|c|}
\hline & & & & & & & & & Butcher $n$ & harks & & & & & \\
\hline Bag \# & Unit\# & Lv. & Taxon & Count & $\mathrm{Wgt}(\mathrm{g})$ & Element & Portion & Juv? & Type & Count & Brks & Burn & Weath & $\mathrm{Pit}$ & Gnaw \\
\hline 41 & TU 01 & 1 & & 36 & 11.34 & & & & & & & 0 & $\mathrm{~N}$ & $\mathrm{~N}$ & \\
\hline 41 & TU 01 & 1 & Aves--medium & 1 & 0.10 & Long bone & Fragment & & & & & 0 & $\mathrm{~N}$ & $\mathrm{~N}$ & \\
\hline & TU 01 & 2 & Odocoileus vriginianus & 2 & 4.02 & Metatarsal & $\begin{array}{l}\text { Fragment of } \\
\text { diaphysis }\end{array}$ & & & & 3 & 1 & 1 & 2 & \\
\hline & TU 01 & 2 & Bovinae & 2 & 9.88 & 1st phalange & Distal end & & & & 2 & 1 & 0 & 0 & \\
\hline & TU 01 & 2 & Mammal--very large & 2 & 9.03 & & & & & & & 0 & $\mathrm{~N}$ & $\mathrm{~N}$ & \\
\hline & TU 01 & 2 & Mammal--small & 2 & 0.18 & & & & & & & 0 & $\mathrm{~N}$ & $\mathrm{~N}$ & \\
\hline & TU 01 & 2 & Osteichthyes & 1 & 0.47 & & & & & & & 1 & $\mathrm{~N}$ & $\mathrm{~N}$ & \\
\hline & TU 01 & 2 & Crotalus atrox & 1 & 0.09 & Vertebra & $\begin{array}{l}\text { No ventral } \\
\text { process }\end{array}$ & & & & & 0 & $\mathrm{~N}$ & $\mathrm{~N}$ & \\
\hline & TU 01 & 2 & Colubridae & 1 & 0.13 & Vertebra & Fragment & & & & & 0 & $\mathrm{~N}$ & $\mathrm{~N}$ & \\
\hline & TU 01 & 2 & Mammal & 10 & 5.70 & & & & & & & 3 & $\mathrm{~N}$ & $\mathrm{~N}$ & \\
\hline & TU 01 & 2 & Mammal & 10 & 4.72 & & & & & & & 2 & $\mathrm{~N}$ & $\mathrm{~N}$ & \\
\hline & TU 01 & 2 & Mammal & 6 & 2.31 & & & & & & & 1 & $\mathrm{~N}$ & $\mathrm{~N}$ & \\
\hline & TU 01 & 2 & Mammal & 1 & 0.93 & & & & Mach. Saw & 2 & 3 & 0 & 1 & 0 & \\
\hline & TU 01 & 2 & Mammal & 1 & 1.03 & & & & Ind. saw & 1 & 3 & 0 & 1 & 0 & \\
\hline & TU 01 & 2 & Mammal & 7 & 4.69 & & & & & & & 0 & 1 & 0 & \\
\hline & TU 01 & 2 & Mammal & 11 & 9.87 & & & & & & & 0 & 0 & 0 & \\
\hline & TU 01 & 2 & Mammal & 5 & 7.30 & & & & & & & 0 & 0 & 2 & \\
\hline & TU 01 & 2 & Mammal & 10 & 6.26 & & & & & & & 0 & 0 & 1 & \\
\hline & TU 01 & 2 & Mammal & 71 & 10.74 & & & & & & & 0 & $\mathrm{~N}$ & $\mathrm{~N}$ & \\
\hline 47 & TU 01 & 3 & Testudinata & 1 & 0.07 & Carapace & Fragment & & & & & 0 & $\mathrm{~N}$ & $\mathrm{~N}$ & \\
\hline 47 & TU 01 & 3 & Mammal & 5 & 1.55 & & & & & & & 1 & $\mathrm{~N}$ & $\mathrm{~N}$ & \\
\hline 47 & TU 01 & 3 & Mammal & 6 & 1.74 & & & & & & & 0 & $\mathrm{~N}$ & $\mathrm{~N}$ & \\
\hline 48 & TU 01 & 4 & Bovinae & 1 & 4.27 & Metapodial & $\begin{array}{l}\text { Fragment of } \\
\text { condyle }\end{array}$ & & & & 2 & 0 & 0 & 1 & \\
\hline 48 & TU 01 & 4 & Mammal--very large & 3 & 8.67 & & & & & & 2 & 0 & 0 & 1 & \\
\hline 48 & TU 01 & 4 & Mammal & 2 & 9.32 & Long bone & Fragment & & & & 3 & 0 & 0 & 2 & \\
\hline 48 & TU 01 & 4 & Mammal & 1 & 4.60 & & & & & & 1 & 0 & 0 & 1 & \\
\hline 48 & TU 01 & 4 & Testudinata & 2 & 0.94 & Carapace & Fragment & & & & & 2 & $\mathrm{~N}$ & $\mathrm{~N}$ & \\
\hline 48 & TU 01 & 4 & Testudinata & 1 & 1.13 & Carapace & Fragment & & & & & 0 & $\mathrm{~N}$ & $\mathrm{~N}$ & \\
\hline 48 & TU 01 & 4 & Mammal & 35 & 10.05 & & & & & & & 0 & $\mathrm{~N}$ & $\mathrm{~N}$ & \\
\hline 48 & TU 01 & 4 & Mammal & 7 & 3.03 & & & & & & & 1 & $\mathrm{~N}$ & $\mathrm{~N}$ & \\
\hline 48 & TU 01 & 4 & Mammal & 7 & 2.90 & & & & & & & 2 & $\mathrm{~N}$ & $\mathrm{~N}$ & \\
\hline 51 & TU 01 & 5 & Mammal & 11 & 6.46 & & & & & & & 0 & 1 & $\mathrm{~N}$ & \\
\hline 51 & TU 01 & 5 & Mammal & 2 & 0.56 & & & & & & & 1 & $\mathrm{~N}$ & $\mathrm{~N}$ & \\
\hline 51 & TU 01 & 5 & Mammal & 1 & 0.27 & & & & & & & 3. & $\mathrm{~N}$ & $\mathrm{~N}$ & \\
\hline 49 & TU 02 & 1 & Artiodactyl & 2 & 6.10 & Metacarpal & $\begin{array}{l}\text { Fragment of } \\
\text { diaphysis }\end{array}$ & & Thin Cut & 7 & 3 & 1 & 1 & 1 & \\
\hline
\end{tabular}




\begin{tabular}{|c|c|c|c|c|c|c|c|c|c|c|c|c|c|c|c|}
\hline & & & & & & & & & Butcher & arks & & & & & \\
\hline Bag \# & Unit\# & Lv. & Taxon & Count & Wgt (g) & Element & Portion & Juv? & Type & Count & Brks & Burn & Weath & Pit & Gnaw \\
\hline 49 & TU 02 & 1 & Artiodactyl & 4 & 11.32 & Humerus & \begin{tabular}{|l} 
Fragment of \\
diaphysis
\end{tabular} & & & & 3 & 0 & 1 & 1 & \\
\hline 49 & TU 02 & 1 & Suidae & 1 & 0.06 & Deciduous incisor & Fragment & Yes & & & & 0 & $\mathrm{~N}$ & $\mathrm{~N}$ & \\
\hline 49 & TU 02 & 1 & Mammal--large & 1 & 1.77 & Vertebra & Centrum & Yes & & & & 0 & $\mathrm{~N}$ & $\mathrm{~N}$ & \\
\hline 49 & TU 02 & 1 & Bovinae & 1 & 6.38 & Proximal sesmoid & $\begin{array}{l}\text { Almost } \\
\text { complete }\end{array}$ & & & & 2 & 1 & 0 & 1 & \\
\hline 49 & TU 02 & 1 & Mammal & 4 & 7.54 & & & & & & & 0 & 1 & 0 & \\
\hline 49 . & TU 02 & 1 & Mammal & 1 & 1.34 & & & & & & & 0 & 2 & 0 & \\
\hline 49 & $\mathrm{TU} 02$ & 1 & Mammal & 1 & 1.88 & & & & & & & 0 & 0 & 0 & \\
\hline 49 & \begin{tabular}{|l|} 
TU 02 \\
\end{tabular} & 1 & Mammal & 3 & 1.64 & & & & & & & 0 & 3 & 0 & \\
\hline 49 & TU 02 & 1 & Mammal--very large & 1 & 2.50 & & & & & & & 2 & 0 & 0 & \\
\hline 49 & TU 02 & 1 & Marmmal & 1 & 0.32 & & & & & & & 3 & $\mathrm{~N}$ & $\mathrm{~N}$ & \\
\hline 49 & TU 02 & 1 & Mammal & 31 & 10.92 & & & & & & & 0 & $\mathrm{~N}$ & $\mathrm{~N}$ & \\
\hline 45 & TU 02 & 2 & Odocoileus vriginianus & 1 & 1.22 & 4th carpal & Complete & & & & 0 & 0 & 0 & 0 & \\
\hline 45 & TU 02 & 2 & Artiodactyl & 1 & 0.58 & Sesmoid & Complete & & & & & 1 & $\mathrm{~N}$ & $\mathrm{~N}$ & \\
\hline 45 & TU 02 & 2 & Artiodactyl & 1 & 1.07 & 1st phalange & Fragment & & & & 3 & 0 & 0 & 0 & \\
\hline 45 & TU 02 & 2 & Rodentia & 1 & 0.05 & Ulna & Fragment & & & & & 1 & 0 & 0 & \\
\hline 45 & TU 02 & 2 & Testudinata & 1 & 0.21 & Carapace & Fragment & & & & & 0 & $\mathrm{~N}$ & $\mathrm{~N}$ & \\
\hline 45 & TU 02 & 2 & Artiodactyl & 1 & 1.61 & Metapodial & Condyle & & & & & 0 & 1 & 1 & \\
\hline 45 & TU 02 & 2 & Mammal--large & 1 & 4.72 & Long bone & Fragment & & & & 1 & 0 & 1 & 0 & \\
\hline 45 & TU 02 & 2 & Mammal--large & 1 & 2.04 & Long bone & Fragment & & & & 3 & 1 & 0 & 1 & \\
\hline 45 & TU 02 & 2 & Mammal--large & 1 & 0.96 & Tooth root & \begin{tabular}{|l|} 
Fragment \\
\end{tabular} & & & & & 1 & $\mathrm{~N}$ & $\mathrm{~N}$ & \\
\hline 45 & TU 02 & 2 & Mammal & 6 & 2.37 & & & & & & & 3 & $\mathrm{~N}$ & $\mathrm{~N}$ & \\
\hline 45 & TU 02 & 2 & Mammal & 1 & 17.00 & & & & & & & 2 & $\mathrm{~N}$ & $\mathrm{~N}$ & \\
\hline 45 & TU 02 & 2 & Mammal & 8 & 4.15 & & & & & & & 1 & $\mathrm{~N}$ & $\mathrm{~N}$ & \\
\hline 45 & TU 02 & 2 & Mammal & 96 & 23.59 & & & & & & & 0 & $\mathrm{~N}$ & $\mathrm{~N}$ & \\
\hline 49 & TU 02 & 3 & Odocoileus vriginianus & 1 & 0.31 & Deciduous molar & $\begin{array}{l}\text { Complete (not } \\
\text { root) }\end{array}$ & & & & & 0 & $\mathrm{~N}$ & $N$ & \\
\hline 49 & TU 02 & 3 & Odocoileus vriginianus & 1 & 9.61 & Astralagus & \begin{tabular}{|l} 
Almost \\
complete
\end{tabular} & & & & 2 & 1 & 0 & 2 & \\
\hline 49 & TU 02 & 3 & Mammal & 1 & 0.09 & & & & & & & 4 & $\mathrm{~N}$ & $\mathrm{~N}$ & \\
\hline 49 & TU 02 & 3 & Mammal & 1 & 0.35 & & & & & & & 3 & $\mathrm{~N}$ & $\mathrm{~N}$ & \\
\hline 49 & TU 02 & 3 & Mammal--large & 1 & 3.08 & Long bone & Fragment & & & & 3. & 3 & 0 & 0 & \\
\hline 49 & TU 02 & 3 & Mammal--large & 1 & 2.56 & Long bone & Fragment & & & & 2 & 1 & 1 & 1 & \\
\hline 49 & TU 02 & 3 & Mammal & 4 & 2.04 & & & & & & & 2 & $\mathrm{~N}$ & $\mathrm{~N}$ & \\
\hline 49 & TU 02 & 3 & Mammal & 12 & 3.41 & & & & & & & 1 & $\mathrm{~N}$ & $\mathrm{~N}$ & \\
\hline 49 & TU 02 & 3 & Mammal & 29 & 10.09 & & & & & & & 0 & $\mathrm{~N}$ & $\mathrm{~N}$ & \\
\hline 50 & TU 02 & 4 & Mammal & 1 & 0.11 & & & & & & & 0 & $\mathrm{~N}$ & $\mathrm{~N}$ & \\
\hline 50 & TU 02 & 4 & Mammal & 1 & 0.32 & & & & & & & 1 & $\mathrm{~N}$ & $\mathrm{~N}$ & \\
\hline 50 & TU 02 & 4 & Mammal & 1 & 0.15 & & & & & & & 2 & $\mathrm{~N}$ & $\mathrm{~N}$ & \\
\hline
\end{tabular}




\begin{tabular}{|c|c|c|c|c|c|c|c|c|c|c|c|c|c|c|c|}
\hline & & & & & & & & & Butcher & arks & & & & & \\
\hline Bag \# & Unit \# & Lv. & Taxon & Count & $\mathrm{Wgt}(\mathrm{g})$ & Element & Portion & Juv? & Type & Count & Brks & Burn & Weath & Pit & Gnaw \\
\hline 50 & TU 02 & 41 & Mammal & 1 & 0.08 & & & & & & & 3 & $\mathrm{~N}$ & $\mathrm{~N}$ & \\
\hline 46 & TU 03 & 2 & Artiodactyl & 1 & 5.541 & Mandible & $\begin{array}{l}\text { Condyl and } \\
\text { part of } \\
\text { coronoid } \\
\text { process }\end{array}$ & & & & 3 & 0 & 1 & 0 & \\
\hline 46 & TU 03 & 21 & Mammal--large & 3 & 3.48 & & & & & & & 0 & $\mathrm{~N}$ & $\mathrm{~N}$ & \\
\hline 46 & TU 03 & 21 & Bos taurus & 1 & 17.82 & 3rd phalange & Lateral $1 / 2$ & & Chop & 1 & 1 & 0 & 0 & 0 & \\
\hline 46 & TU 03 & 2 & Bovinae & 1 & 7.90 & 1st phalange & Lateral $1 / 3$ & & Chop & 1 & 1 & 0 & 0 & 0 & \\
\hline 46 & TU 03 & 21 & Mammal--very large & 1 & 32.02 & Tibia & $\begin{array}{l}\text { Fragment of } \\
\text { diaphysis }\end{array}$ & & & & 1 & 0 & 0 & 0 & \\
\hline 46 & TU 03 & 2 & Bovinae & 1 & $4.61 \mathrm{I}$ & Proximal sesmoid & Complete & & & & 요 & 0 & 0 & 0 & \\
\hline 46 & TU 03 & 2 & Bovinae & 1 & 3.89 & Proximal sesmoid & Complete & & & & 0 & 0 & 0 & 0 & \\
\hline 46 & TU 03 & 2 & Bovinae & 1 & 2.02 & Distal sesmoid & Fragment & & & & & 0 & 0 & 0 & \\
\hline 46 & TU 03 & 2 & Bos taurus & 3 & 18.00 & Ischium & $\begin{array}{l}\text { Rump cut } \\
3 / 4^{\prime \prime}\end{array}$ & & Hand saw & 2 & 3 & 0 & 0 & 0 & \\
\hline 46 & TU 03 & 2 & Bos taurus & 3 & 16.17 & Ischium & $\begin{array}{l}\text { Rump cut } \\
3 / 4^{\prime \prime}\end{array}$ & & Hand saw & 2 & 3 & 0 & 0 & 0 & \\
\hline 46 & TU 03 & 2 & Mammal--very large & 1 & 7.02 & Rib & Fragment & & & & 3 & 0 & 0 & of & \\
\hline 46 & TU 03 & 2 & Bovinae & 1 & 3.13 & 3rd phalange & Fragment & & & & 2 & 0 & 0 & 0 & \\
\hline 46 & TU 03 & 2 & Bovinae & 1 & 1.68 & 3rd phalange & Fragment & & & & 3 & 0 & 0 & 0 & \\
\hline 46 & TU 03 & 2 & Mammal--very large & 4 & 14.02 & Long bone & Fragment & & & & 1 & 0 & of & 0 & \\
\hline 46 & TU 03 & 2 & Mammal & 1 & 1.65 & & & & Hand saw & 1 & 3 & 0 & 0 & 0 & \\
\hline 46 & TU 03 & 2 & Mammal & 36 & 34.00 & & & & & & & 0 & 0 & 0 & \\
\hline 46 & TU 03 & 2 & Mammal & 3 & 1.97 & & & & & & & 0 & 1 & 0 & \\
\hline 46 & TU 03 & 2 & Mammal & 58 & 11.29 & & & & & & & 0 & $\mathrm{~N}$ & $\mathrm{~N}$ & \\
\hline 46 & TU 03 & 2 & Mammal & 2 & 0.40 & & & & & & & 1 & $\mathrm{~N}$ & $\mathrm{~N}$ & \\
\hline 46 & TU 03 & 2 & Mammal & 3 & 0.98 & & & & & & & 2. & $\mathrm{~N}$ & $\mathrm{~N}$ & \\
\hline 46 & TU 03 & 2. & Mammal & 3 & 1.17 & & & & & & & 3 & $\mathrm{~N}$ & $\mathrm{~N}$ & \\
\hline 46 & TU 03 & 2. & Mammal & 1 & 0.35 & & & & & & & 4 & $\mathrm{~N}$ & $\mathrm{~N}$ & \\
\hline 54 & TU 04 & 4 & Mammal & 1 & 0.08 & & & & & & & 0 & $\mathrm{~N}$ & $\mathrm{~N}$ & \\
\hline 60 & TU 04 & 5 & Mammal & 2 & 1.32 & & & & & & & 0 & $\mathrm{~N}$ & $\mathrm{~N}$ & \\
\hline 53 & TU 05 & 2 & Mammal--very large & 2 & 16.07 & & & & & & 2 & of & 1 & 1. & \\
\hline 53 & \begin{tabular}{|l|l|} 
TU 05 \\
\end{tabular} & 2 & Mammal--very large & 1 & 4.46 & & & & & & 2 & 0 & 1 & 2 & \\
\hline 53 & TU 05 & 2 & Mammal & 2 & 0.73 & & & & & & & 2 & $\mathrm{~N}$ & $\mathrm{~N}$ & \\
\hline 53 & TU 05 & 2 & Mammal & 2 & 1.90 & & & & & & & 1 & $\mathrm{~N}$ & $\mathrm{~N}$ & \\
\hline 53 & TU 05 & 2 & Mammal & 1 & 0.73 & & & & & & & 0 & 0 & 0 & \\
\hline 53 & TU 05 & 2 & Mammal & 2 & 1.71 & & & & & & & 0 & 1 & $\mathrm{~N}$ & \\
\hline 53 & TU 05 & 2 & Mammal & 3 & 3.62 & & & & & & & 0 & 0 & 2 & \\
\hline 53 & TU 05 & 2 & Mammal & 25 & 7.46 & & & & & & & 0 & $\mathrm{~N}$ & $\mathrm{~N}$ & \\
\hline 55 & TU 05 & 3 & Mammal--very large & 1 & 3.58 & & & & & & 2 & 0 & 0 & 2 & \\
\hline
\end{tabular}




\begin{tabular}{|c|c|c|c|c|c|c|c|c|c|c|c|c|c|c|c|}
\hline & & & & & & & & & Butche & larks & & & & & \\
\hline Bag \# & Unit \# & Lv. & Taxon & Count & Wgt (g) & Element & Portion & Juv? & Type & Count & Brks & Burn & Weath & Pit & Gnaw \\
\hline 55 & TU 05 & 3 & Mammal & & 0.13 & & & & & & & 0 & $\mathrm{~N}$ & $\mathrm{~N}$ & \\
\hline 55 & TU 05 & 3 & Mammal & 1 & 0.80 & & & & & & & 2 & $\mathrm{~N}$ & $\mathrm{~N}$ & \\
\hline 56 & TU 05 & 4 & Mammal & 1 & 0.30 & & & & & & & 0 & $\mathrm{~N}$ & $\mathrm{~N}$ & \\
\hline 57 & TU 05 & & Mammal & 1 & 0.42 & & & & & & & 3 & $\mathrm{~N}$ & $\mathrm{~N}$ & \\
\hline
\end{tabular}


